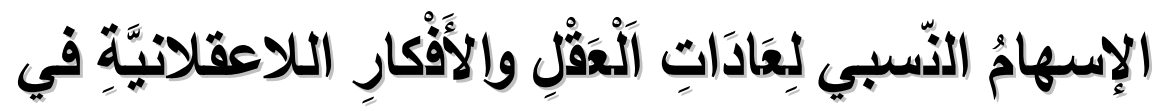

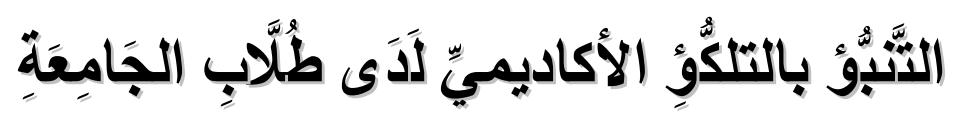

\author{
إعـداد \\ د. حسن سعد محمود عابدين \\ أستاذ علم النفس التربوي المساعد \\ كلية التريية- جامعة الإسكندرية
}

DOI: 10.12816/0045604

مجلة الدراسات التربوية والانسانية ـ كلية التربية ـ جامعة دمنهور .

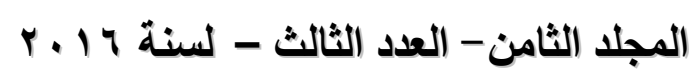




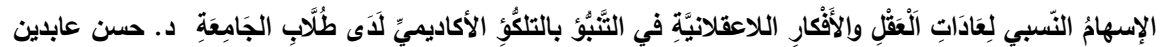


مجلة الدراسات التربوية والانسانية ـ كلية التربية ـ جامعة دمنهور . المجلد الثامن - العدد(ץ)- لسنة 1 ـ ـ؟

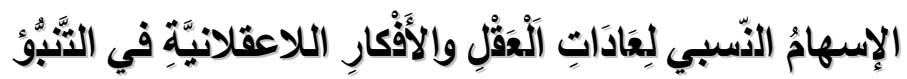

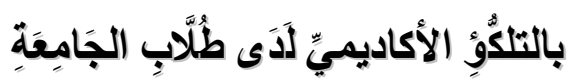

د. دمن سعد محمود عابدين

\section{DOI: 10.12816/0045604}

مقدمة:

يُعدُّ التلكُُُّ الأكاديمي من الأمور المُنتشرة لاى الطلاب، وخاصـة في المرحلة

الجامعية، فإحساس الطالب بانتقاله لهذه المرحلة أنه أصبح أكثر حريةً واعتمادًا

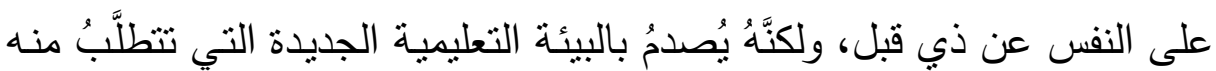

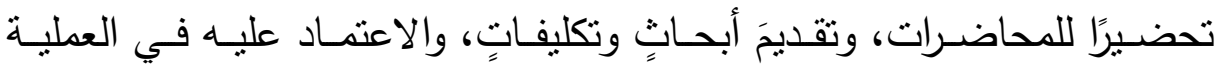
التعليمية بصورة أكبر ، كما أنه يوجد بعض الطلاب ممَّن يُشاركون ويُساعدون

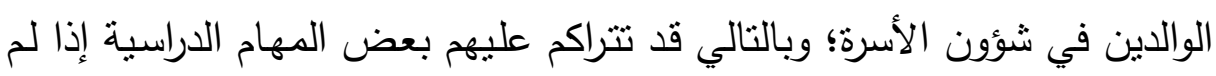

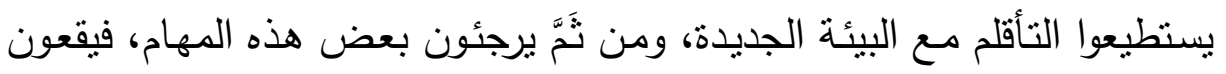
فريسة للتلكؤ الأكاديمي.

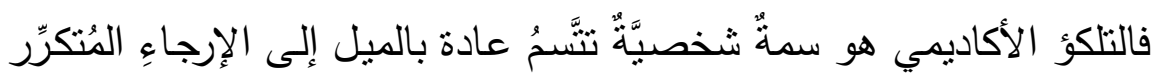
لإنجاز الأعمال المطلوبـة مـع التبريـر غير المنطقي لتأخيرهـا عن مواعيدها.

(Dewit \& Schauwenburg, 2002)

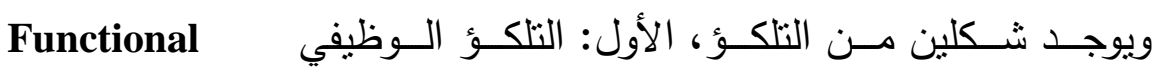

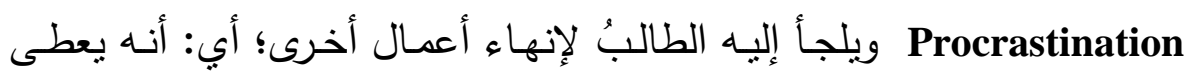

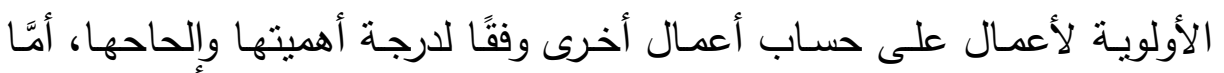
الثكل الثاني: التلكؤ غير الوظيفي Nonfunctional Procrastination وهو هو التأجيل المتعدد للقيام بالمهام من السهل أداؤها ولها أهميتها وإلحاحها، فالخطورة هنا في النوع الثاني وهو التلكؤ غير الوظيفي.

ويثير (Brownlow,S\&Reasinger,R.,2000) إلى أن التلكؤ غير الوظيفي يُعطلُّ أداء الطالب، ويُسبِّبُ له شعورًا بالتوتر وعدم الارتياح. 
كما أنَّ للتلكؤ الأكاديمي أسبابًا، والتي منها الطالب نفسه وما يؤمن به من أفكار ومعتقدات حول نفسه أو حول المعرفة أو ما يمتلكه من عاداتٍ قد تكابل تكون خاطئةً في تعامله مع المهام الأكاديمية.

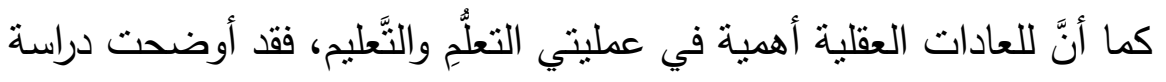
(Bergman,D.,2007)

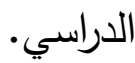
ويُوضِّح (Costa,A. \&Kallick,B.,2000) أنَّ إهمال استخدام عادات العقل

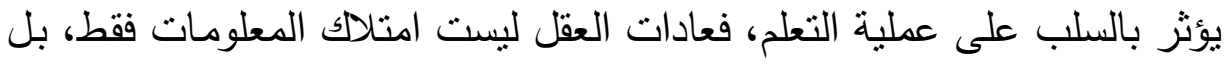
تشمل توظيف هذه المعلومات واستخدامها.

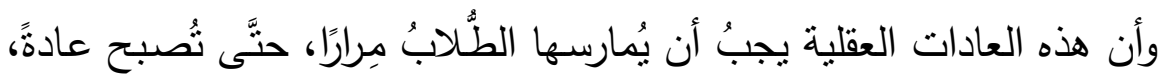
وأن أفضل طريقة لاكتساب هذه العادات وتتميتها هي تقديمها للطلاب من خلال الكال

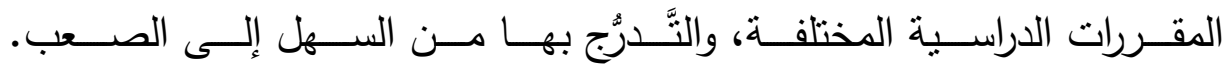

(Beyer,B.,2003)

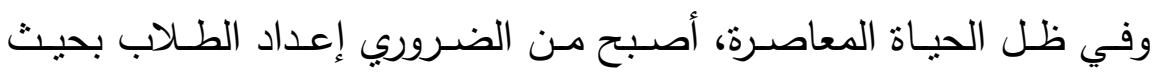

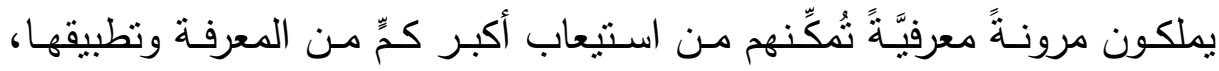
فالعاداتُ العقلية سلوكياتُ يجب التدريب عليها، فالكثير من طلابنا يفتقر لامتلاك

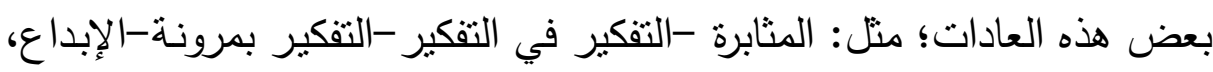
ولذلك لابد أن تكون هذه العادات جوهر عملية التعلم والتعليم، فالعادات العقلية تؤثر في تعلم وتعليم الطلاب.

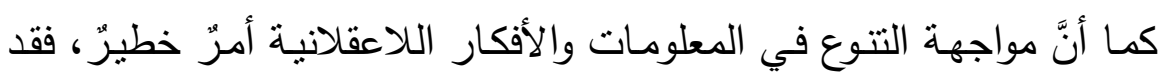

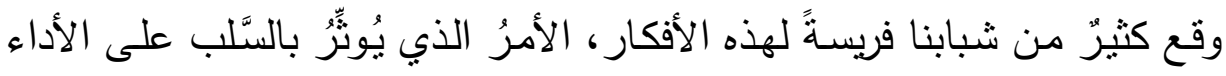

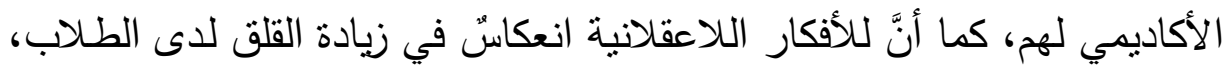

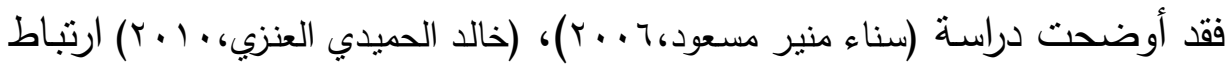
قلق المستقبل بالأفكار اللاعقلانية لدى الطلاب. 
وبُمُنّلُ طلابُ المرحلة الجامعية ثروةً بشريَّةً للوطن، باعتبارهم قوة دافعة نحو

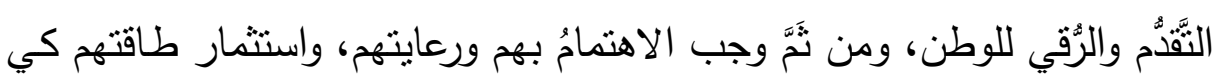

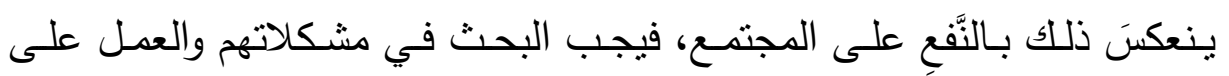
حلِّهـا، ومـن المشـكلات اللافتـة للنَّظـرِ لـدى شـباب الجامعـة، مشـكلة التلكؤ الأكاديمي وهي تأجيلُ القيام بالمهام الأكاديمية. مشكلة البحث: تعد مشكلة التلكؤ مـن المشكلات اليوميـة المنتشـرة في حياتتـا اليوميـة، فبعض الأفراد يؤجلون القيام بأعمالهم للحظات الأخيرة أو تركها نهائيًا، ومن خلال عمل

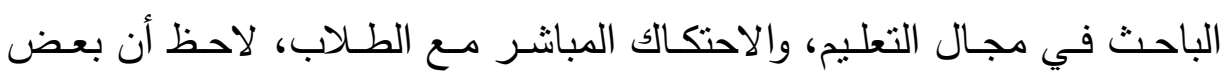
الطلاب يلجؤون إلى تأخير ما يكلفون به من مهام إلى أخر وقت يمكن القيام بـه، أو عدم القيام بـه تماًًَا. وقد أثـارت بعض الدراسـات إلى انتشـار التلكؤ الأكاديمي للدى الطـلاب ففي دراسـة (السبد عبد الدايم سكران، ( • ب) توصلت إلى انتشار التلكؤ الأكاديمي لدى طلاب المرحلة المتوسطة(الإعدادية) بنسبة م,عـ\% وفي المرحلة الثانويـة 1,0؛ \% أي أن هناك زيادة في نسبة التلكؤ الأكاديمي بزيادة المرحلة التعليمية،

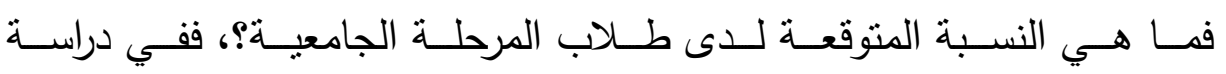
وجد أنَّنسبة الطلاب الذين يعانون من (Simpson,K.\&Timothy,A.,2009)

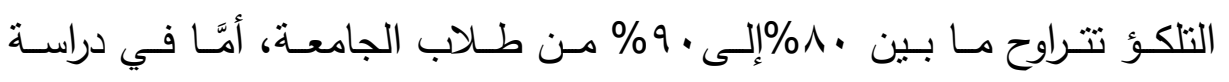

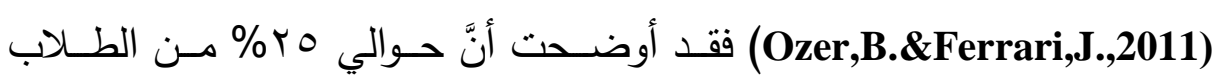

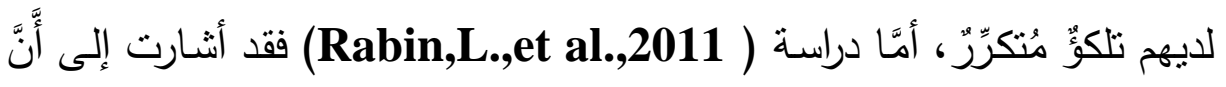
حوالي · r\% إلى • ج\%من طلاب الجامعة يقومون بتأجيل مهامهم الأكاديمية، وكذلك في البلدان العربيـة، ففي دراسـة (خالد زكي الربابعـة، ـ ا ـ ب) وجد أنَّ

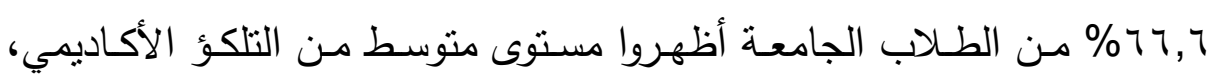

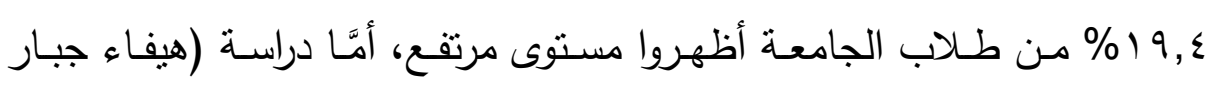

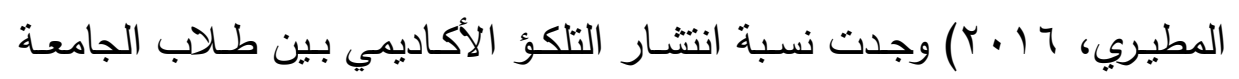


وصلت إلى 09 r \% \% ، كما أوضحت بعض الدراسات وجود مستوى مرتفع من التلكؤ الأكاديمي لَدى الطلاب، منل: دراسة (Balkis,M.,2011)، ( Jiao,Q.,et

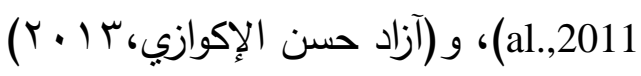

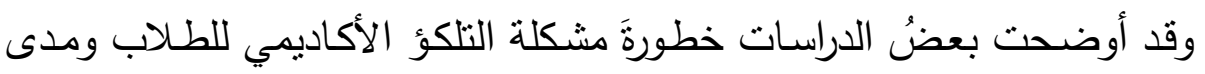

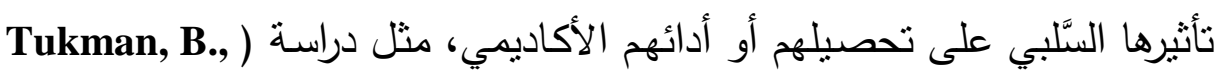

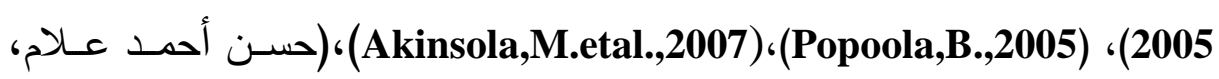
(Y...

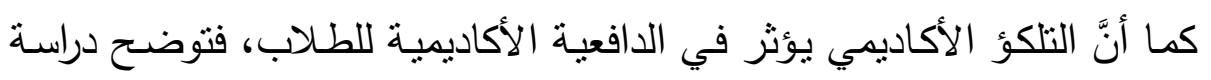

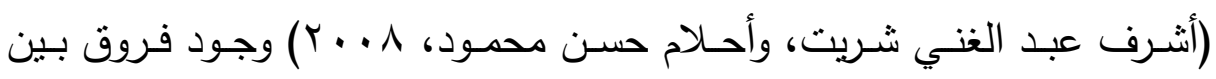

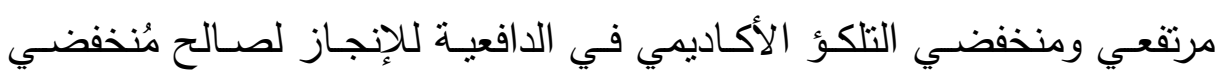
التلكؤ، وكذلك دراسـة (Odaci H., 2011)،Sirin E., 2011)، (محمد ذياب

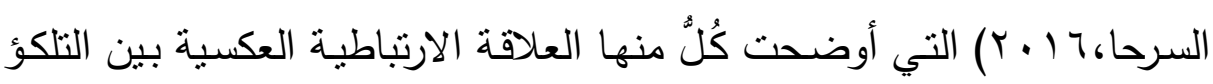
الأكاديمي والدافعية الأكاديمية للطلاب.

كما أوضحت بعض الدراسـات التأثير السلبي للتلكؤ الأكاديمي على الفاعلية

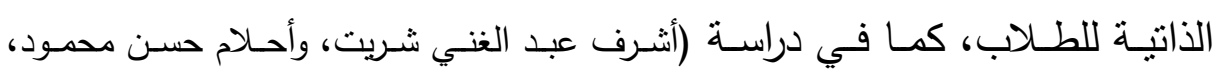

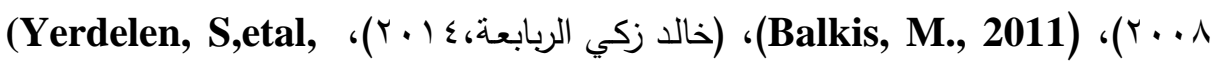

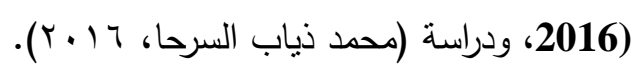

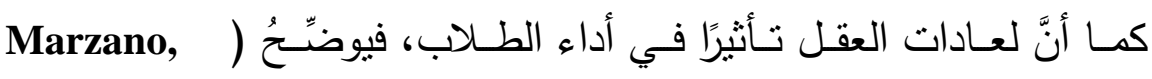
(A.,2000) أنَّ عادات العقل الضعيفة تؤدي إلى تعلم ضعيف لدى الطلاب، كما

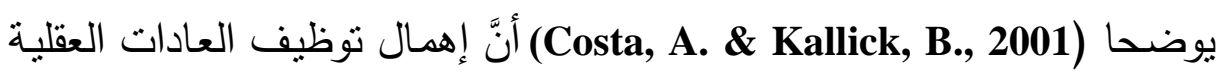

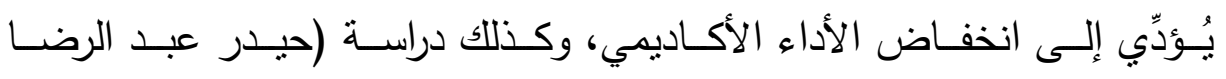

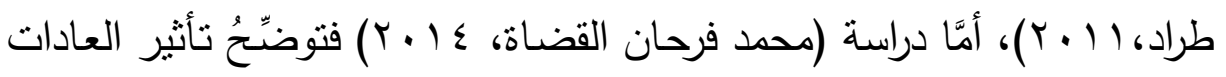

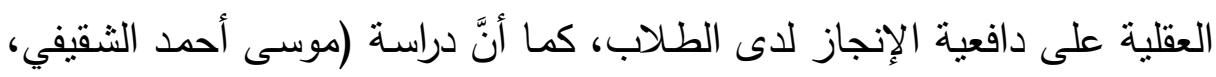

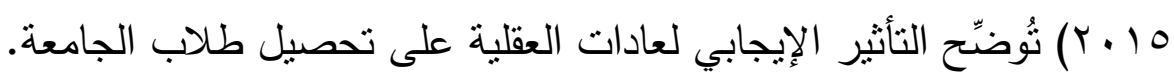


كمـا أنَّ الأفكار اللاعقلانيـة تُؤُثِّرُ بالسَّلب على الأداء الأكاديمي للطـلاب،

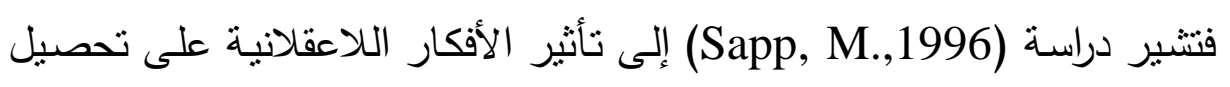

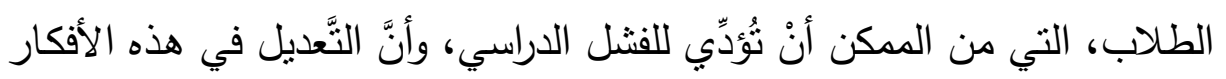

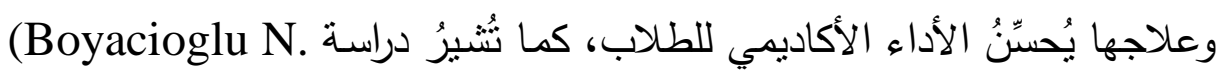
Kucuk L., 2011)

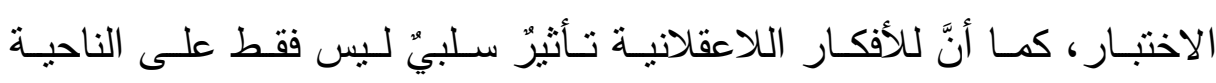

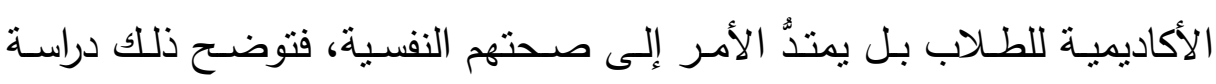

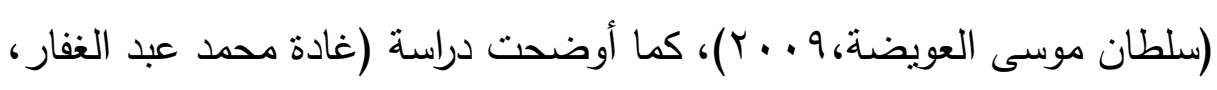

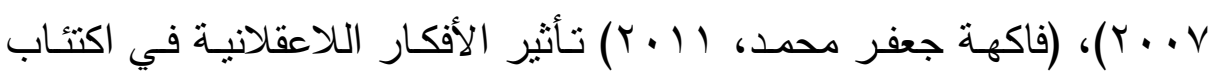

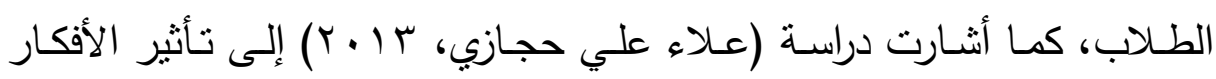
اللاعقلانية في القلق الاجتماعي لدى الطلاب. ويُشتير (Ellis,A.\&Knaus,W.,2002) إلى أن تأجيل القيـام بالمهام هـو اضطراب انفعالي، ينتج عن معتقدات لاعقلانية، نتيجة اعتقاد الطالب بأنَّ الأداء

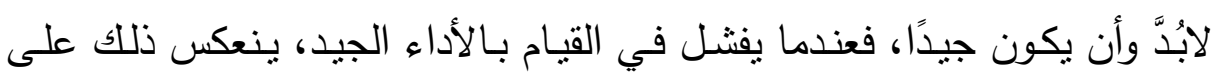

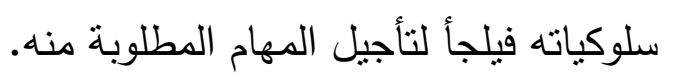
وقد أشـارت دراسـة (Bridgees,K.\&Riog,M.,1997) إلى تـأثنير الأفكار اللاعقلانية في التلكؤ الأكاديمي لدى الطلاب، وأكدت ذلك دراسـة (سبد أحمد

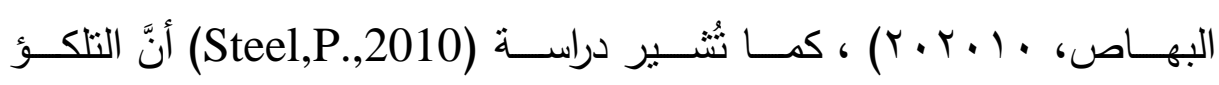

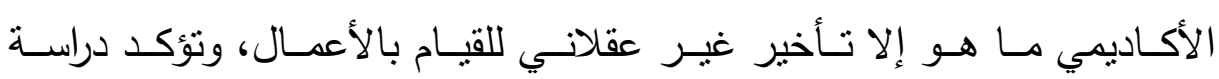
(Yazici,H.\&Bulut,R.,2015) الأكاديمية يرجع لأسباب غير واقعية.

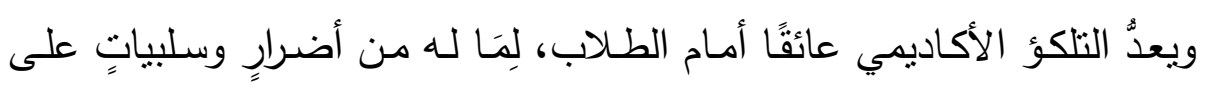

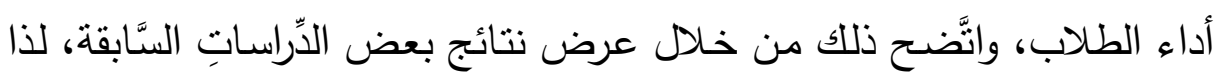

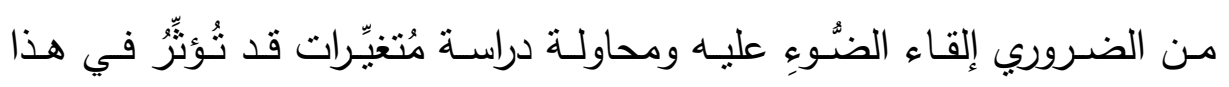




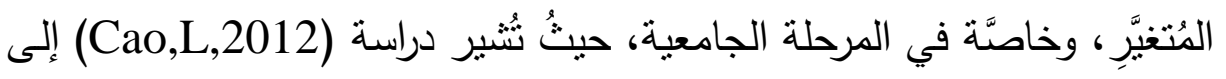

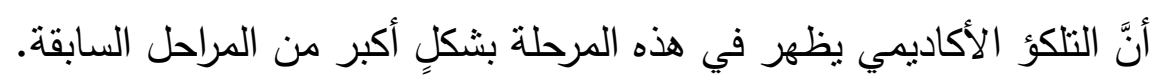

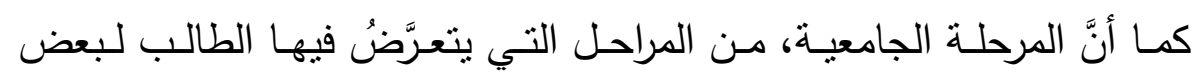

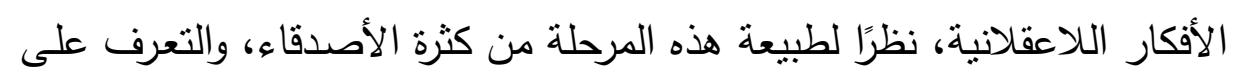

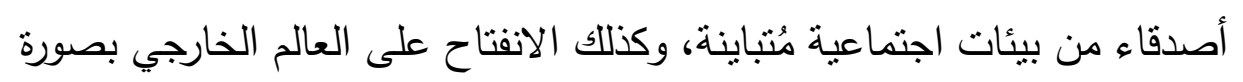

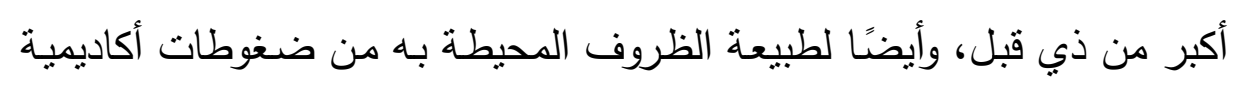

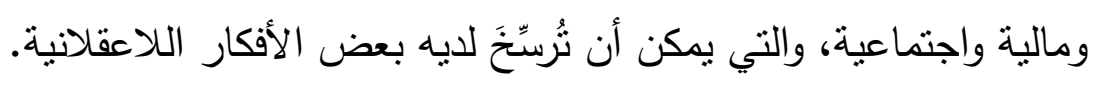

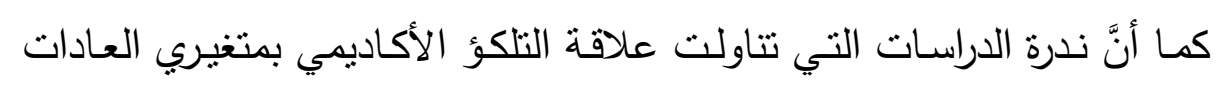

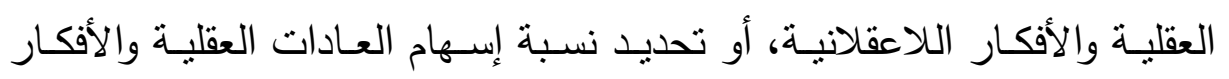

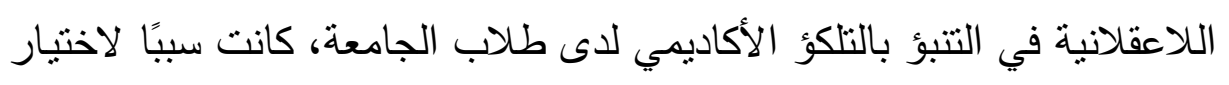
هذا الموضوع. ويمكن تلخيص مشكلة البحث الحالي في محاولة الإجابة على الأسئلة التالية: 1-ما مستوى التلكؤ الأكاديمي لاى طلاب كلية التربية-جامعة الإسكندرية؟

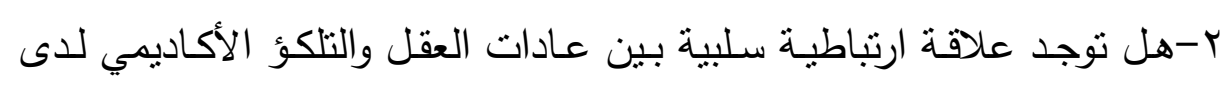

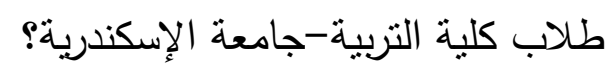

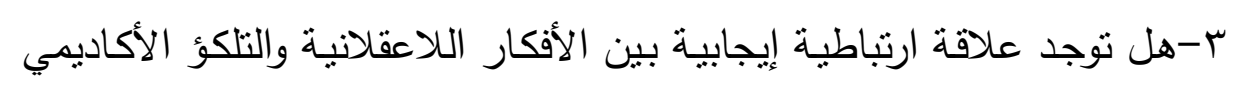

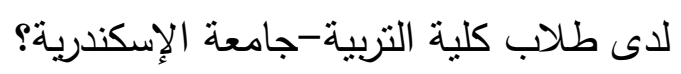

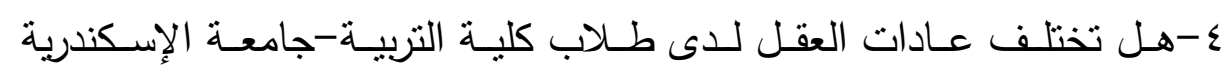

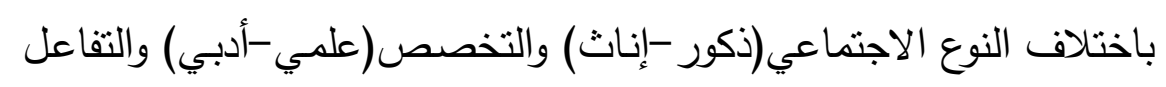

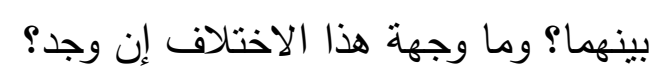

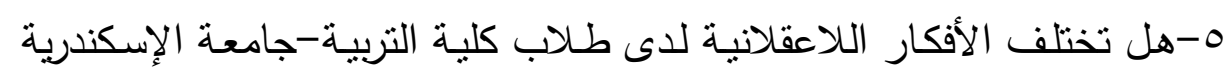

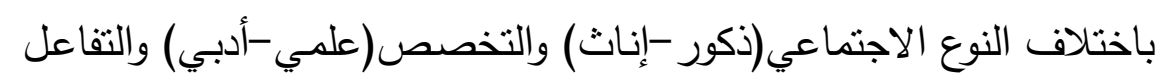
بينهما؟ وما وجهة هذا الاختلاف إن وجد؟ الأن 
צ- هل يختلف التلكؤ الأكاديمي لدى طلاب كلية التربيـة-جامعـة الإسكندرية

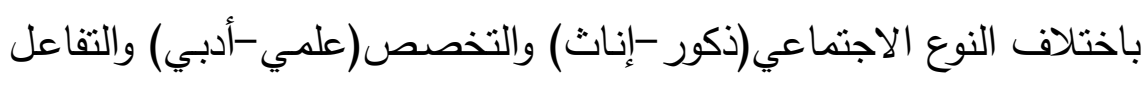

$$
\text { بينهما؟ وما وجهة هذا الاختلاف إن وجد؟ الاعبك }
$$

V- هل توجد فروق ذات دلالـة إحصائية بين منوسطات درجات وجلات طلاب كليـة

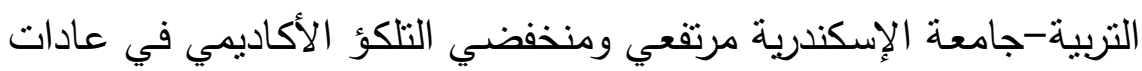

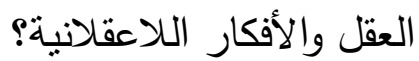

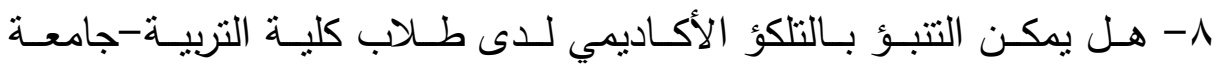

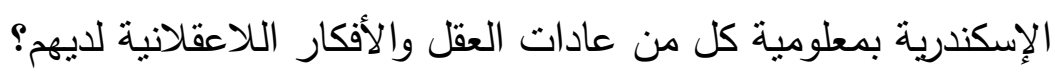

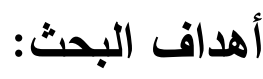

$$
\text { يرهذف البحث الحالي إلى ما يلي: }
$$

1-التعـرف على مسـتوى التلكؤ الأكـاديمي لـدى طـلاب كليـة التربيـة جامعــة

$$
\text { الإسكندرية. }
$$

r-الكشف عن العلاقة بين التلكؤ الأكاديمي وكل من عادات العقل والأفكار اللاعقلانية لدى طلاب كلية التربية جامعة الإسكندرية.

r-الكثف عن الفروق في التلكؤ الأكاديمي وعادات العقل والأفكار اللاعقلانية

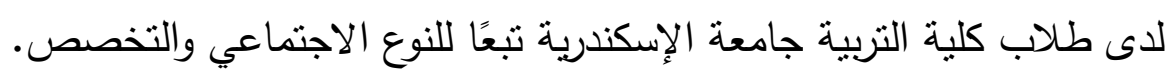

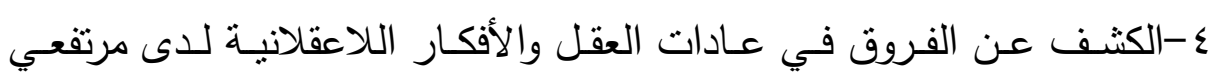
ومنخفضي التلكؤ الأكاديمي من طلاب كلية التربية جامعة الإسكندرية.

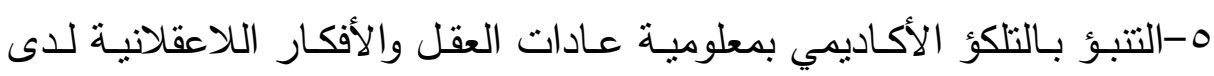
طلاب كلية التربية جامعة الإسكندرية.

\section{أهمية البحث:}

$$
\text { ترجع أهمية البحث الحالي إلى ما يلي: }
$$

1- تتاول الموضوع مُتغِيّرات ذات أهمية كبيرة في مجال علم النفس، لما لها من الهن

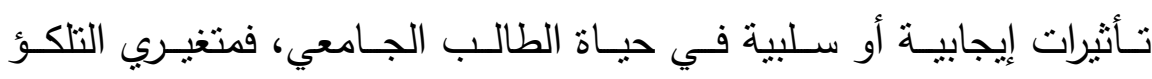

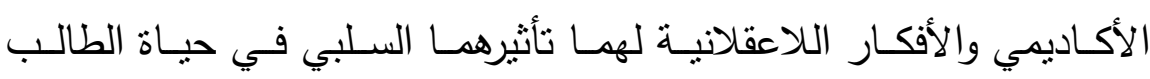


الجامعي، وكذلك متغير عادات العقل له تأثيره الإيجابي، فهذا البحث تبيه

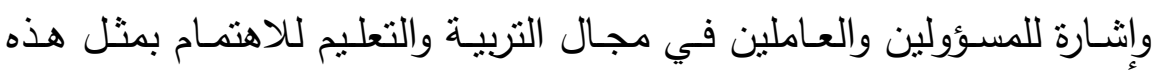
المتغيرات.

ب-إلقـاء الضـوء على مشـكلة التلكؤ الأكـاديمي، وكذللك أهميـة عـادات العقل للطلاب، وأيضًا خطورة الأفكار اللاعقلانية وتأثنرها السلبي على الطلاب.

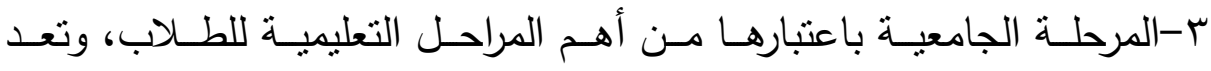

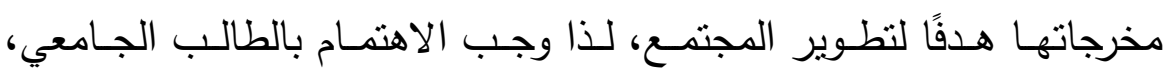
والتفكير في حل المشكلات التي تواجهاه، مما سيعود بالنفع على المجتمع.

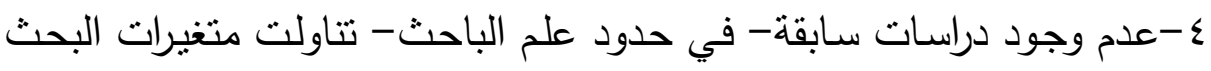

الثناثة معًا.

\section{ثانيًا: الأهمية التطبيقية:}

ا.إضـافة ثلاثة مقاييس جديدة للبيئة العربية، يمكن أن تكون موجهة ومرشدة

$$
\text { لباحثين آخرين. }
$$

r.لفت نظر القائمين على عملية التعلم بخصائص عادات العقل، والاستفادة منها

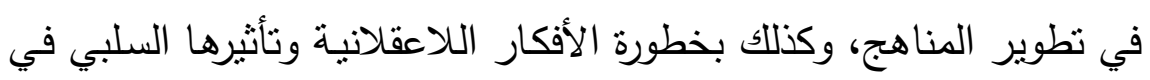
حياة الطلاب الأكاديمية، وذلك عن طريق عقد دورئ دورات وندوات لذلك.

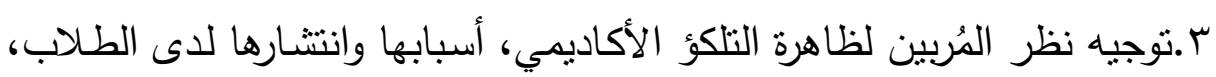

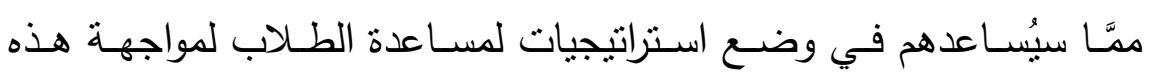

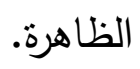

ـ .في ضوء نتائج البحث الحالي يأمل الباحث أن تكون ذات فائدة للمُختصين

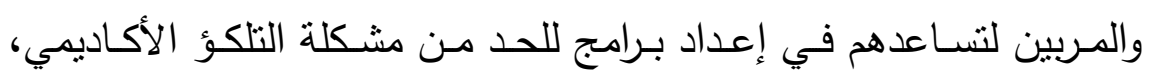
وانتشار الأفكار اللاعقلانية، وتدعيم العادات العقلية الإيجابية للطلاب. 


\section{مصطلحات البحث الإجرائية:}

Academic Procrastination التلكؤ الأكاديمي يعرف على أنَّه تأجيل وتجنب إتمام المهام الأكاديمية التي يجب إنجازها خـال الته

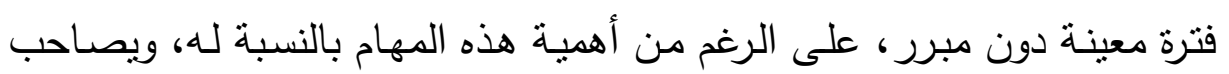

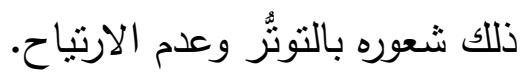
ويقدر بالدرجة التي يحصل عليها الطالب في مقياس التلكؤ الأكاديمي المستخدم وعنداج في البحث.

- عادات العقل Habits of Mind

أنماط عقلية لدى الطالب، توظف ما لديه من دوافع لاختيار أفضل السلوكيات

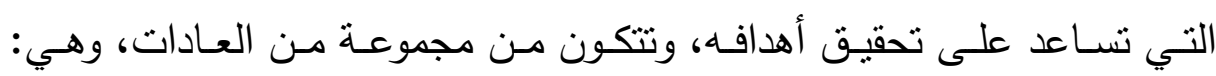

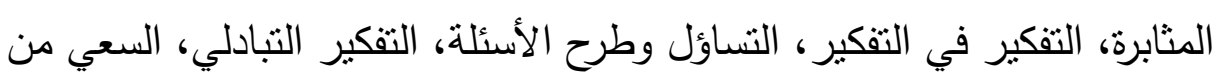

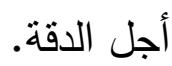
تقدر بالدرجة التي يحصل عليها الطالب في مقياس عادات العقل المستخدم في

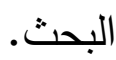

Irrational Thought الأفكار اللاعقلانية مجموعة من الأفكار الخاطئة والتي يؤمن بها الطالب نتيجة خبرات معينـة مر

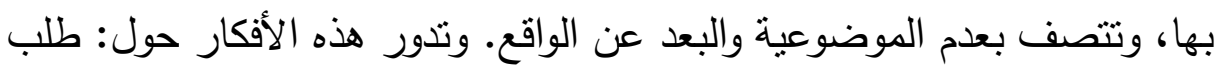

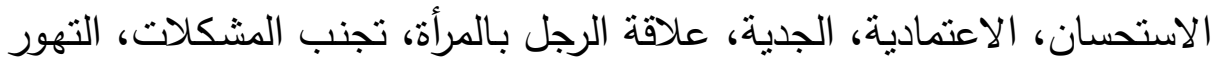
الانفعالي، ودور الحظ في الحياة. تقدـر بالدرجـة التـي يحصـل عليهـا الطالب في في مقيـاس الأفكـار اللاعقلانيـة المستخدم في البحث. 
الإطار النظري والارلسات السابقة

\section{أولاً: التلكؤ الأكاديمي Academic Procrastination}

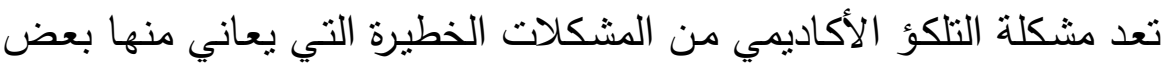

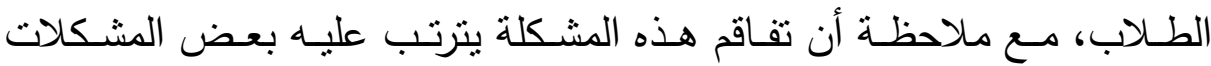

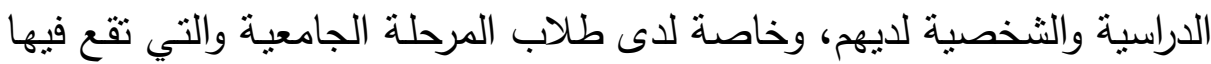
مسؤولية أكبر على الطالب من حيث اختياره لأساليب تعلمه وتتظيمه لوقته، وقد اختلف الباحثون حول ترجمة مصطلح Academic Procrastination البعض هن لهن ترجمها التسويف الأكاديمي أو الإرجاء الأكاديمي، والبعض الأخر ترجمها التلكؤ

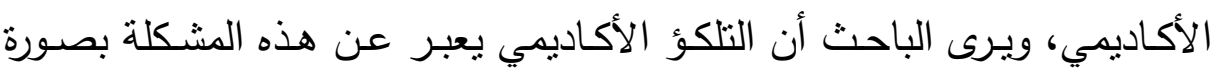

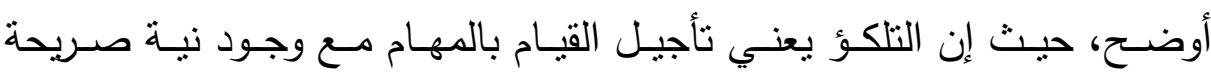

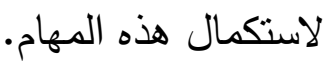

ويعرف (Yaakub, N., 2000) التلكؤ الأكاديمي على أنه تأجيل إنجاز شيء ما إلى وقت لاحق، فهو سلوك متعلم يعيق الفرد نحو تحقيق أهداف، ويمثل

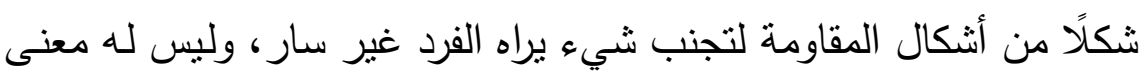
بالنسبة له.

كما يعرفهـ (Mayer,C.,2000) بأنـه سمة شخصية تمثنل عائقًا ذاتيًَا مزمنًا يسيطر على أداء الفرد لمهامه الأكاديمية، سواء في البدء أو الانتهاء منها ومحاولة إكمالها تحت ضغط الوقت في اللحظات الأخيرة. كما يعرفه (Wolters,C.,2003) بأنه الإخفاق في أداء نشاط ضمن الإطار

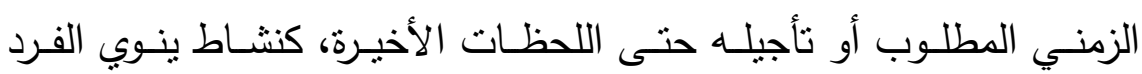
إكمالها في النهاية.

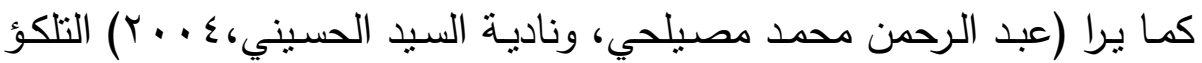

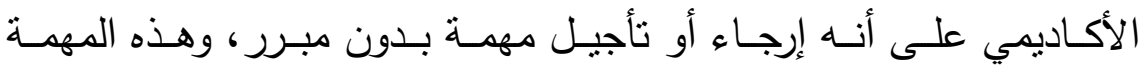

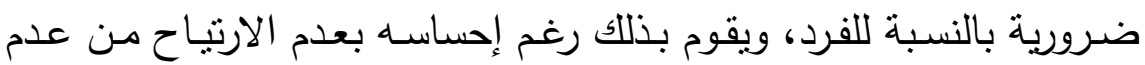
البدء أو الانتهاء منها. 
ويعرف التلكؤ الأكاديمي على أنه نأجيـل الفرد البدء في المهام، حتى يشـر بضغوط بسبب عدم قيامه لها في وقت سابق. (Popoola,B.,2005) كما يعرفه (Balkis,M.,2011) تأجيل المهام الذي يستطيع الطالب القيام بها بشكل سهل بسبب افتقاره لمهارات تتظيم الوقت.

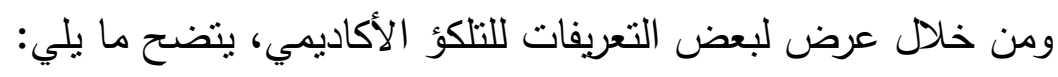
ا-بأخير البدء في أداء المهمة أو تأجيل إكمالها. r-عدم وجود مبرر للتأجيل. ب- بأهية المهمة للطالب. ع-الثعور بالتوتز وعدم الارتياح.

ويعرفه الباحث على أنه تأجيل وتجنب إتمام المهام الأكاديمية التي يجب إنبام إنجازها

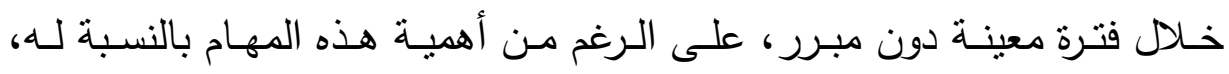
ويصاحب ذلك شعوره بالتوتر وعدم الارتياح.

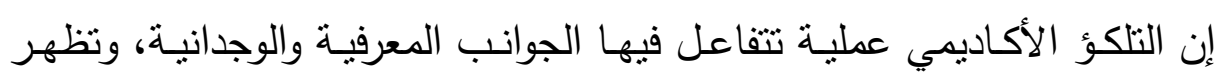

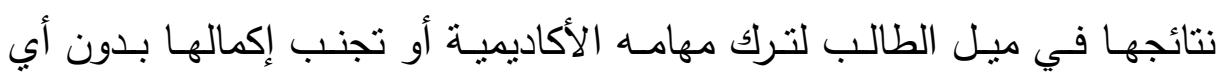
أسباب مهمة. (Rakes,G.\&Dunn,K.2010) ويوضحا (Lavoie, C. \& Koestner, R., 1997) أن من الآثار الجانبية

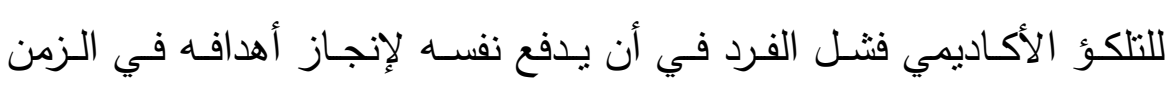

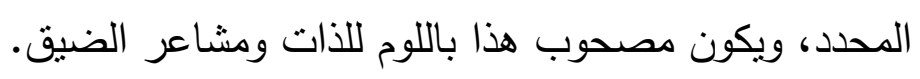

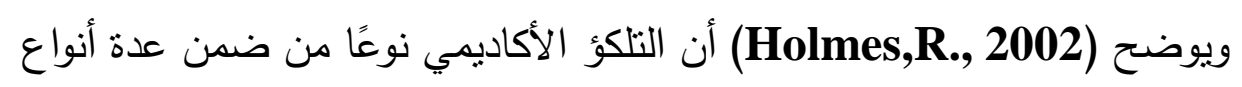
للتلكؤ، وهذه الأنواع هي: 1-التلكؤ الأكاديمي Academic Procrastination ويتمثل في تأجيل الطلاب مهامهز الأكاديمية. r-التلكـؤ القـراري Decisional Procrastination يتمثنل في تأجيـل اتخـاذ

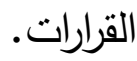




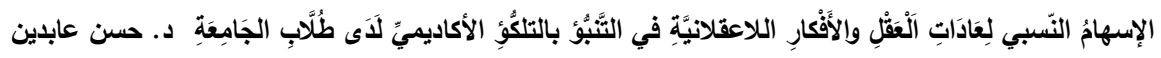

r-التلكؤ العصبي Neurotic Procrastination يتمثنل في تأجيـل القرارات الرئيسة.

ع-التلكؤ القهري compulsive Procrastination يتمنل في تأجيل أنشطة الحياة

اليومية.

كما أن للتلكؤ شكلين، هما:

1-التلكؤ الإيجابي Active Procrastination يتمثل في تأجيل اتخاذ القرارات بطريقة مقصودة، لإكمال أعمال أخرى، فمن يتصفون بهذا الثكل لايهم دافعية عالية تحت ضغط العمل، وهم قادرون على إنجاز مهامهم في الوقت المحدد.

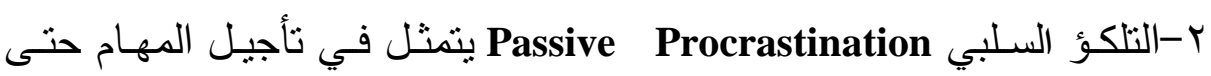
اللحظات الأخيرة، ومن يتصفون بهذا الثكل غير قادرون على اتخاذ القرار للقيام

بهذه المهام. (Chu,A.\&Choi,j.,2005)

وتوضِّـحُ دراســة (Habelrih,E.\&Hicks,R.,2015) أنَّ التلكـؤ الإيجـابي

يسهم في تحقيق صحة ورفاهية أكثر عند الطلاب، فالتلكؤ الإيجابي يؤدِّي

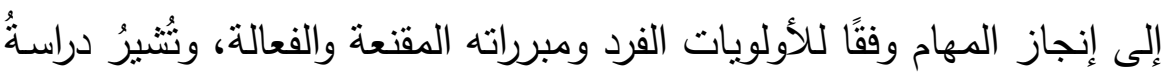
(Choi,J.\&Moran,S.,2009)

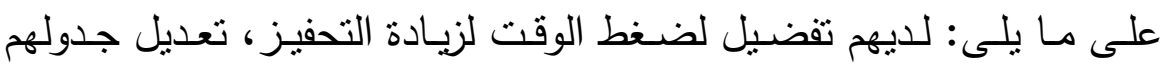

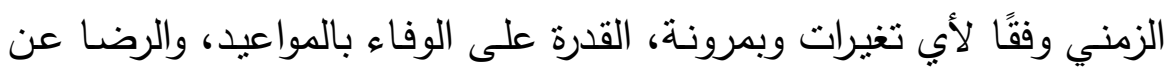
النتيجة وتحفيز النفس تحت ضغط العمل، أمَّا التلكؤ إذا كان بدون سبيًا مقنعًا فهو سلوكُّ سلبيُّ.

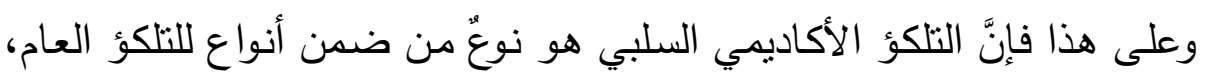

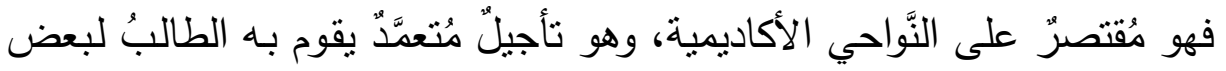

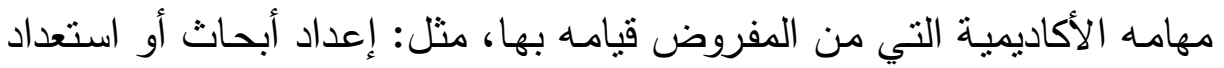

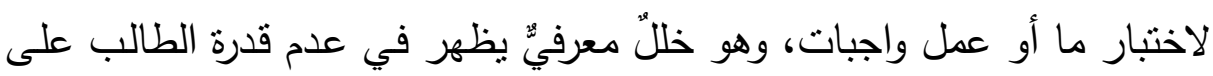
تحديد أولوياته، ويصحب ذللك نوعٌ من النََّتُرِ وعدم الارتياح. 


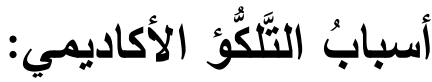

تتعدَّد أسباب التلكؤ الأكاديمي الذي يُعاني منه بعضُ الطلاب، حيث نشير

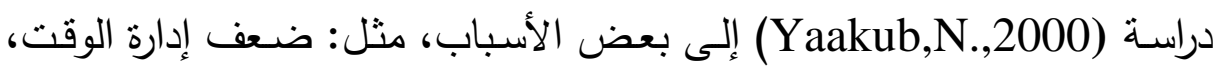
عدم القدرة على التركيز ، عدم اليقظة أثناء أداء المهام، والخوف والقلق.

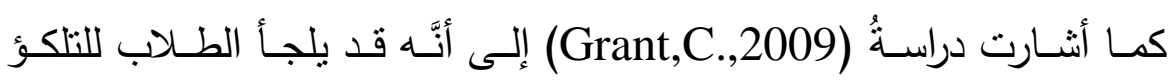

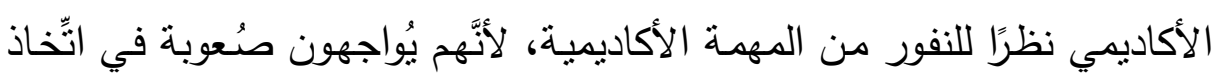

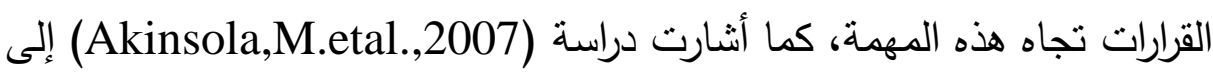

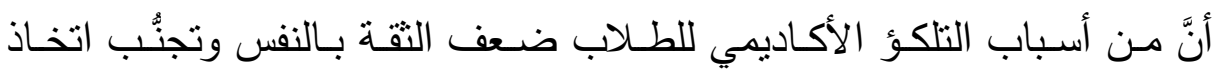
القرار، أما دراسـة (Klassen,R.\&Kuzucu,E.,2009) فنتير إلى أن تأجيل الطلاب لأداء مهامهم الأكاديمية قد يكون راجعًا إلى مشاهدة التليفزيون ووسائل الإعلام الإكترونية وألعاب الكمبيوتر ، كما تشير دراسـة (Balkis,M.,2011) إلى أنَّ الافتقار لمهارات تتظيم الوقت سبب التلكؤ الأكاديمي لاى الطلاب، أمَّا في دراسة (Michinov,N.,et al.,2011) أوضحت أنَّ الفروق بين المتلكئين

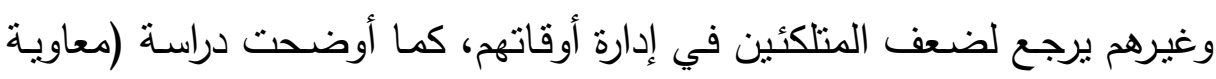

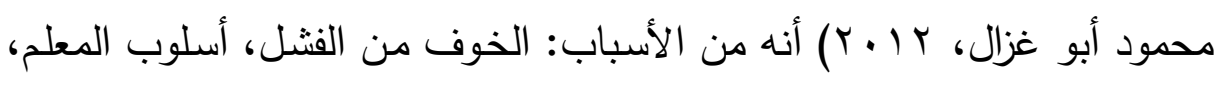

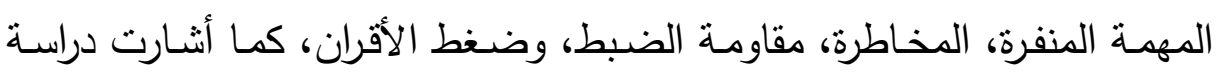
(Demeter,D.\&Pavis,S.,2013)

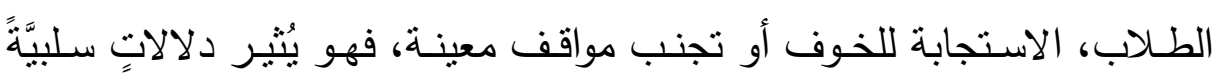

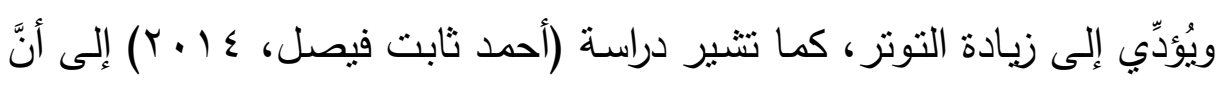

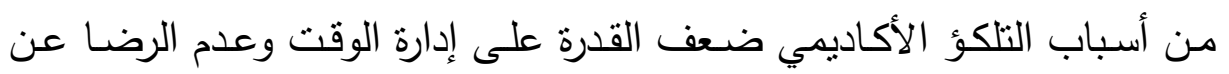
الدراسة. 
وعلى هذا فللنكؤ الأكاديمي أكثر من سبب، ويمكن أن نلخص هذه الأسباب في النالي: 1 أسباب تتعلق بالفرد مثل سمات الثخصية كالخوف وانطباعه الثخصي عن نفسـه وتقديره لذاته، ضـعف التقة بـالنفس، وكذللك عدم القدرة على إدارة الوقت، وقلة التزكيز، والخوف من الفثل.

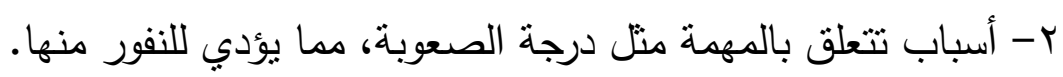
r- أسباب تتعلق بالمحيطين بالفرد منل الأقران والمعلم.

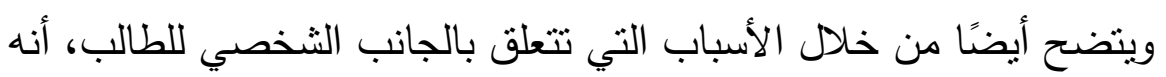

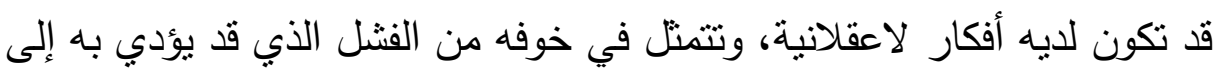

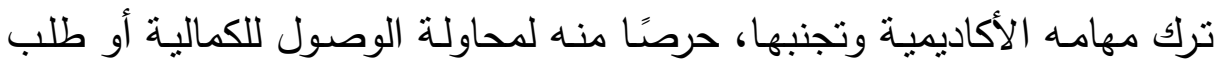

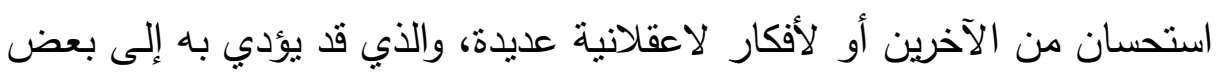
العادات السيئة في طرق استذكاره. أبعاد التلكؤ الأكاديمي:

قد تتـاول عدد مـن الباحثين قيـاس التلكؤ الأكاديمي مـع تحديد أبعاد لـه، والبعض الأخر من الباحثين تتاولوه كممل لسلوكيات تقيس مدى تأجيل الطلاب لمهامهم الأكاديمية، ففي دراسة (حسن أحمد علام، 1 . . ب) حدد الأبعاد التالية:

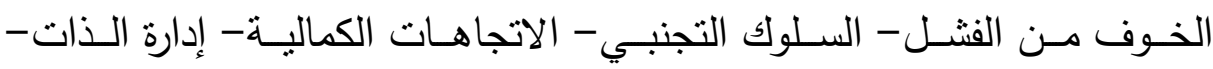

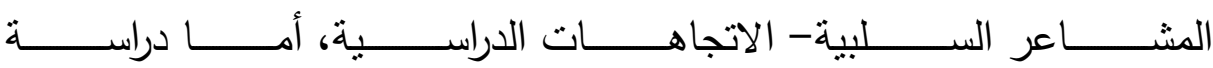
(Choi,J.\&Moran,S.,2009) الرضا عن النتيجة- تفضيل الضغط- القرار المتعدد- الوفاء بالمواعيد النهائية،

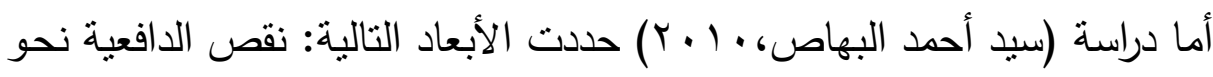

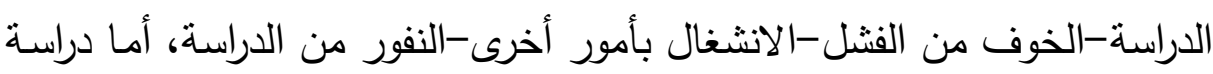

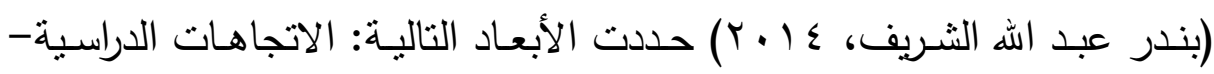
السلوك التجنبي- المشاعر الانفعالية السلبية- تقدير الذات-ا لاتجاهات الكمالية

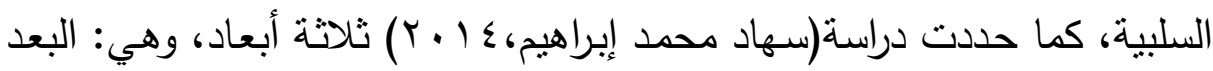


المعرفي - السلوكي - الانفعالي، وكذلك أوضحت دراسـة (وليد شوفي سحلول،

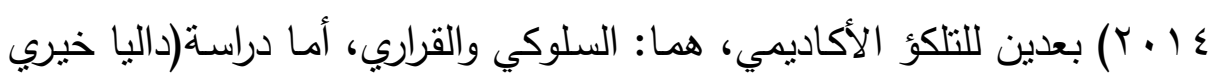

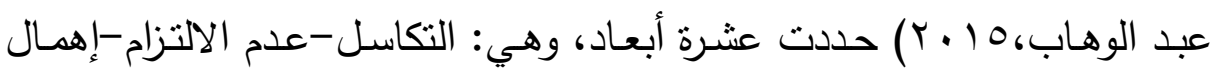

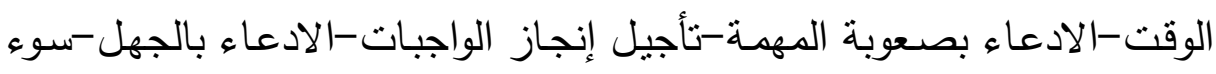

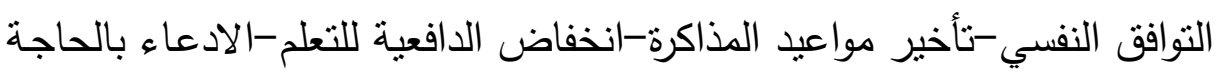

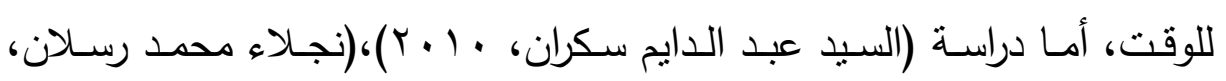

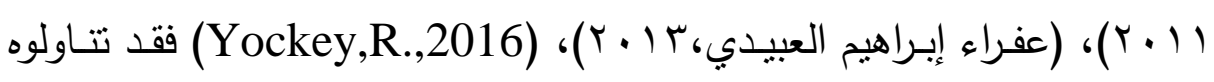
كمجمل لسلوكيات التأجيل. وكذلك يشير (Steel,p.,2010) أنه لا داعي لأبعاد مختلفة للتلكؤ الأكاديمي ،

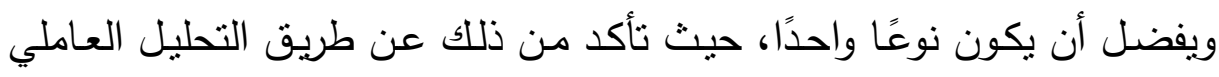

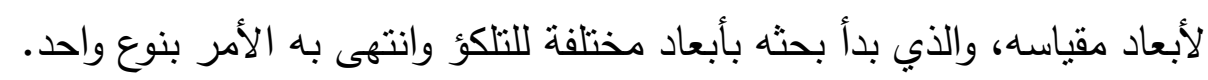

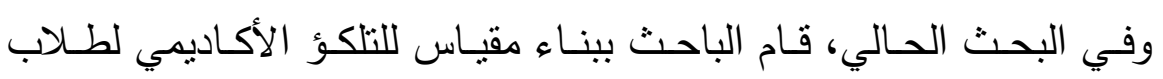

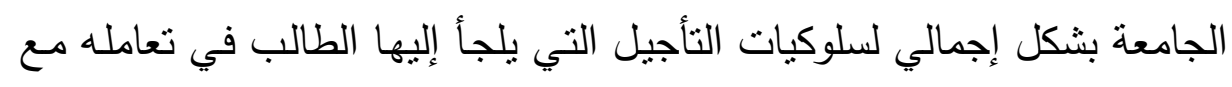
مهامه الأكاديمية. خصائصنُ الطُّلابِ المُتبكئين أكاديميًا: تشير دراسـة (عبد الرحمن محمد مصيلحي، ناديـة السيد الحسيني، ؟ . . ب)

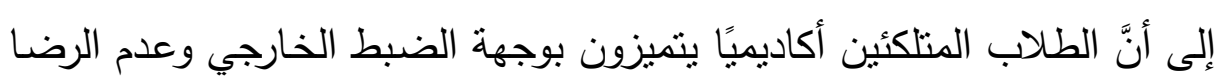

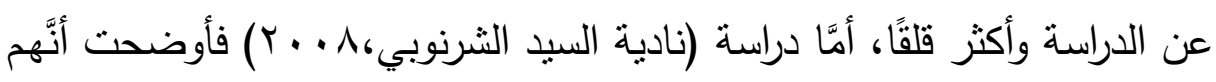

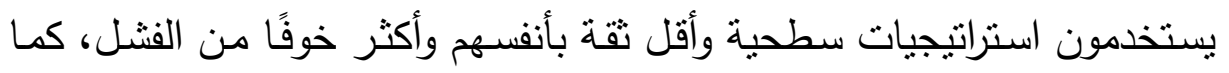
تشير دراسـة ( Flett,A.,et al.,2016) إلى أنَّ المنلكئين أكثر اكتئبًا، وأقل تركيز وليس لايهه المرونة الكافية للتعامل.

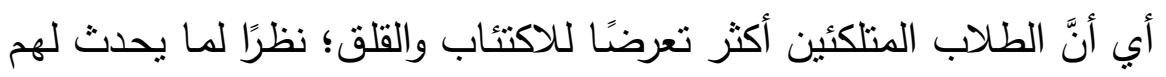

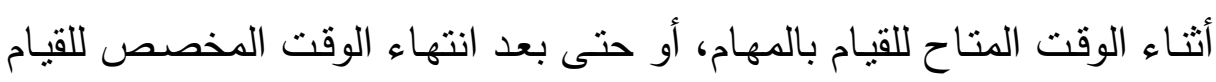

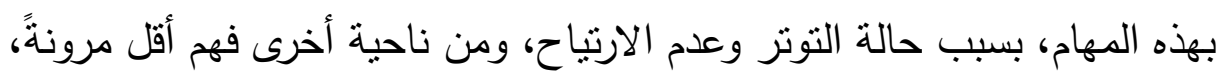


ويستخدمون استراتيجيات سطحية في التعامل مع المهام الأكاديمية، وهذه إثارةً لضعف العادات العقلية لايهم.

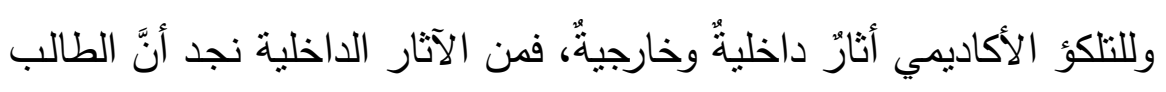

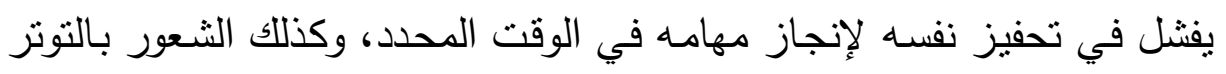

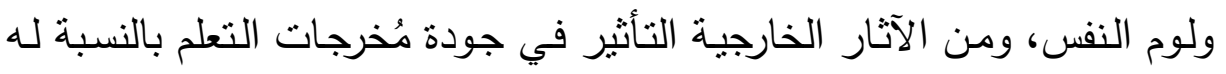

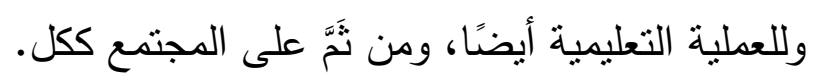

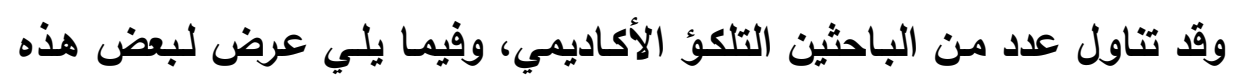

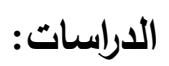
دراسة (Brownlow, S. \& Reasinger, R., 2000) التي هدفت إلى الى

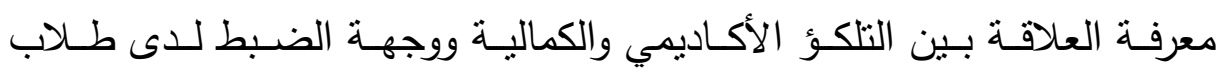

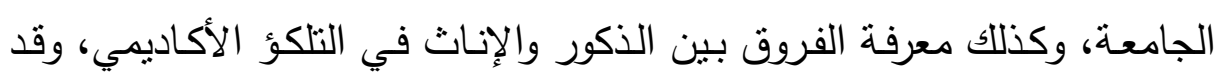

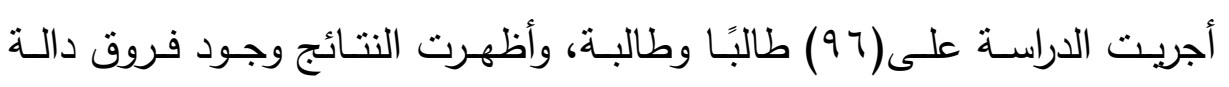

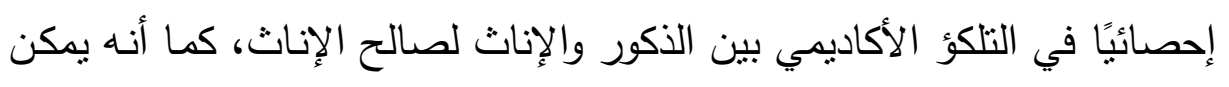
التبؤ بالتلكؤ الأكاديمي كمن خلال وجهة الضبط والكمالية. دراسة (Akinsola M. et al., 2007) التي هدفت إلى معرفة طبيعة

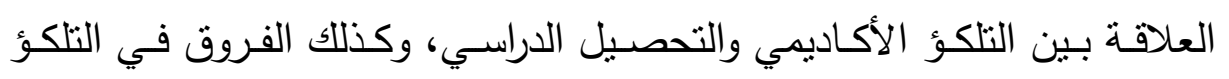

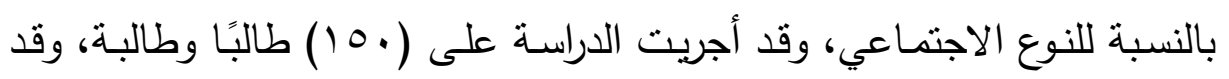

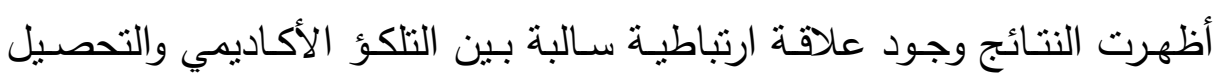

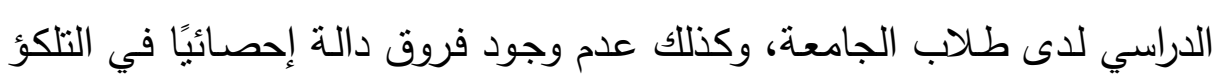

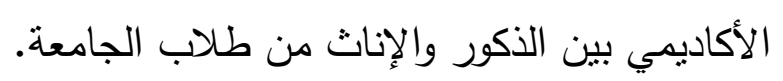

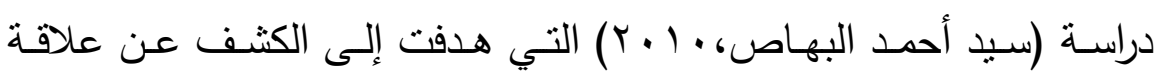

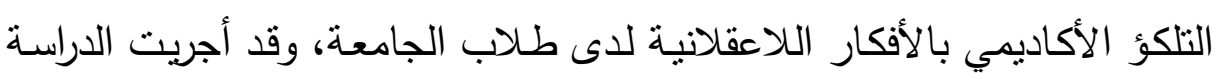

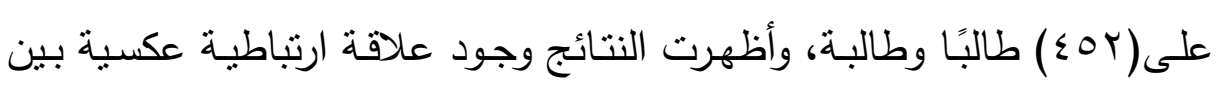

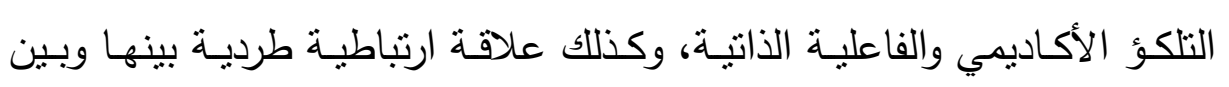

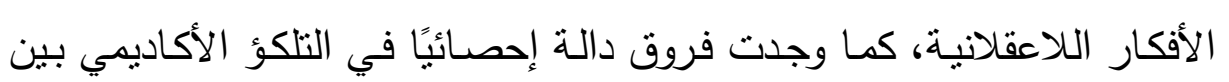


الذكور والإنـاث لصـالح الذكور ، وعدم وجود فروق في التلكؤ الأكاديمي تبعًا للتخصص، كما أنه لا توجد فروق دالة إحصـائًا في الأفكار اللاعقلانية تبعًا للنوع الاجتماعي.

دراسـة (ALAttiyah,A.,2011) التـي هـدفت إلى التعـرف على علاقـة

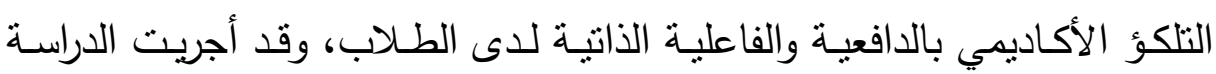

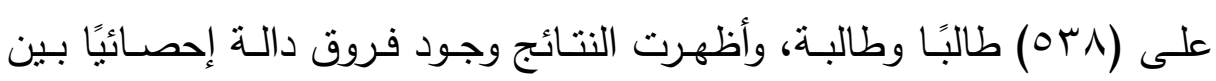

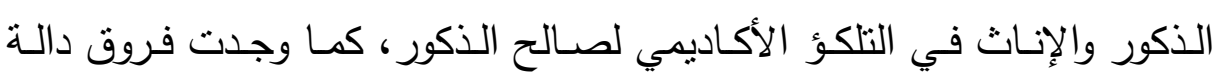

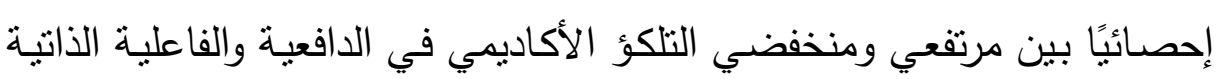
لصالح منخفضي التلكؤ الأكاديمي. دراســة(Balkis,M.,2011) التي هدفت إلـى الكثـف عن مسـتوى التلكؤ

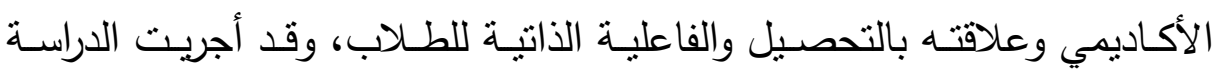
على( ؟ جr) طالبًا وطالبة، وقد أظهرت النتائج وجود مستوى مرتفع لدى الطلاب

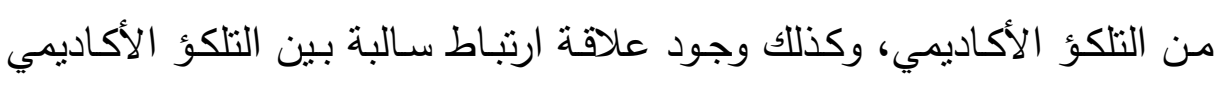
وكل من التحصيل والفاعلية الذاتية الأكاديمية. دراسـة ( Odaci,H.,2011) التي هدفت إلى معرفـة العلاقـة بـين التلكؤ

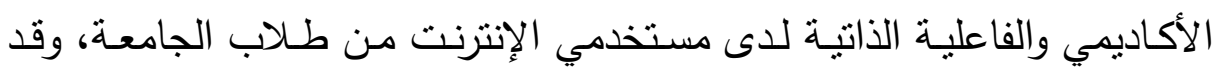

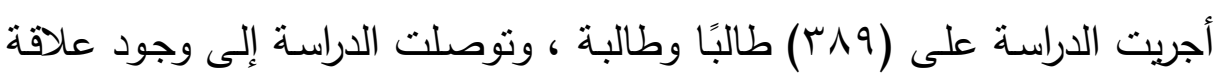

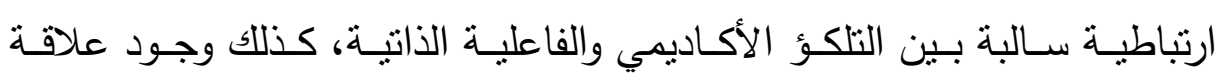

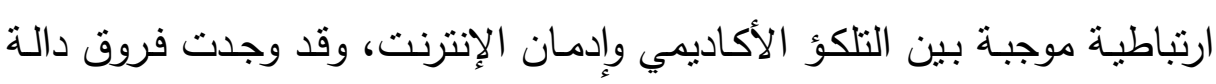

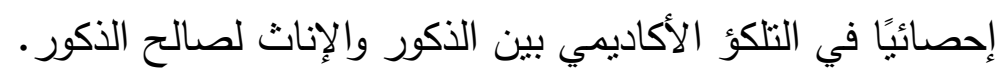

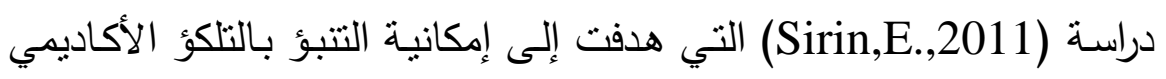

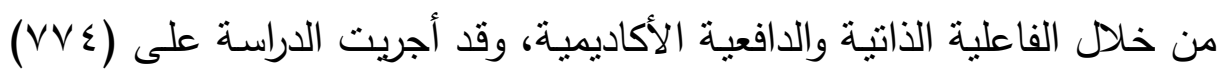

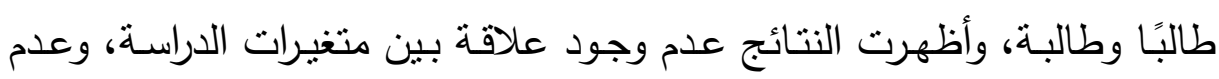
إمكانية التتبؤ بالتلكؤ الأكاديمي من خلا الفاعلية الذاتية أو الدافعية الأكاديمية، وكذلك عدم وجود فروق دالة إحصائيًا في التلكؤ الأكاديمي بين الذكور والإناث. 
دراسة (Jiao,Q.,et al.,2011) التي هدفت إلى الكثف عن مستوى التلكؤ

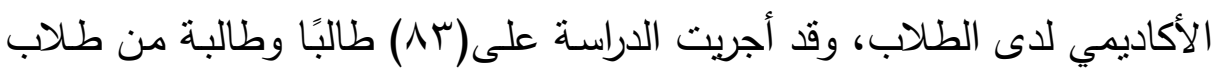

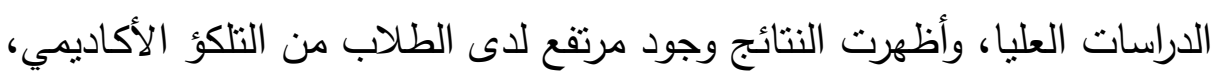
وكذلك عدم وجود فروق دالة إحصائيًا في التلكؤ الأكاديمي بين الذكور والإناث.

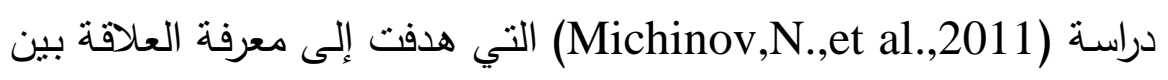

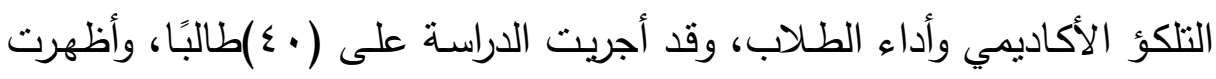

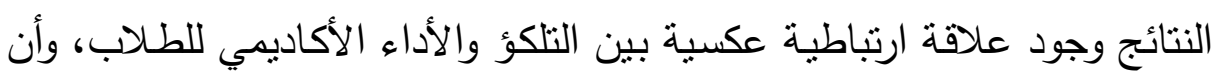

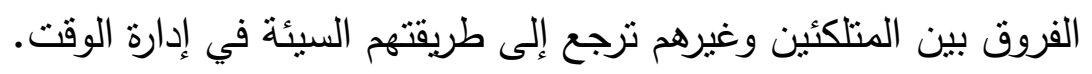

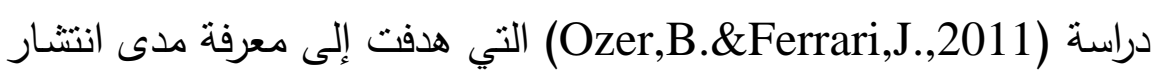

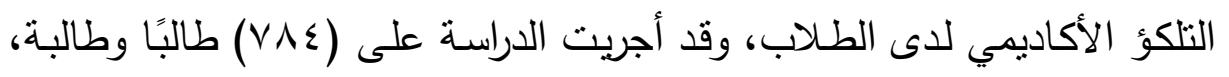

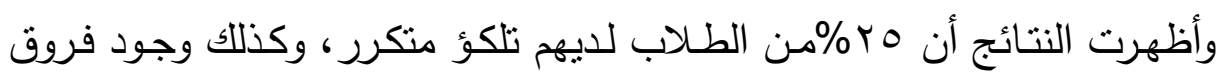

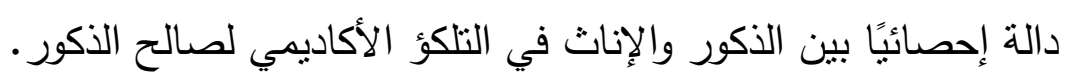

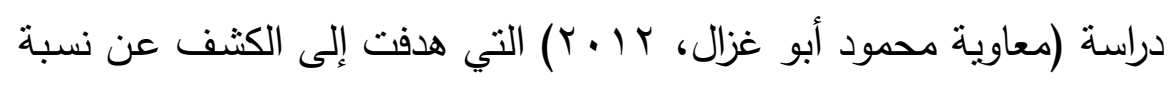

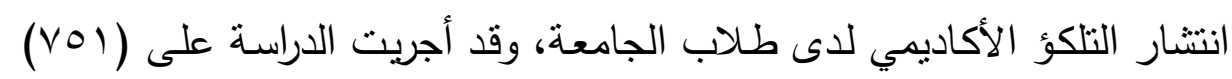

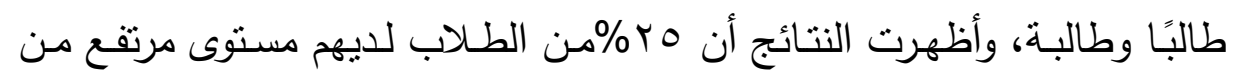

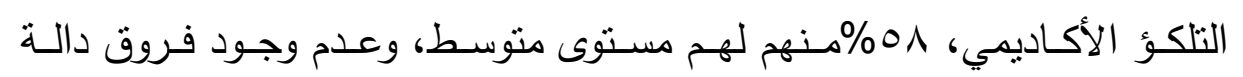

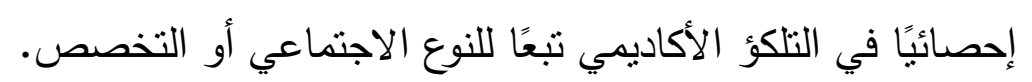

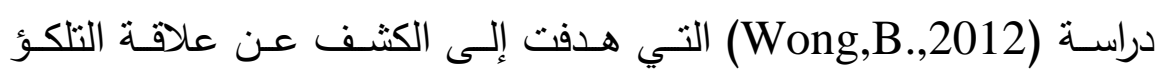

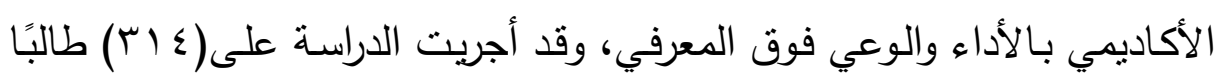

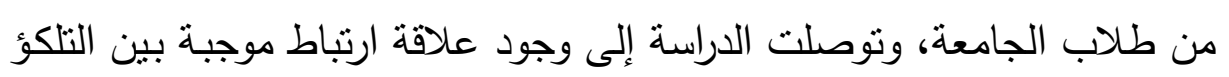
الأكاديمي وكل من الوعي فوق المعرفي والأداء الأكاديمي للطلاب.

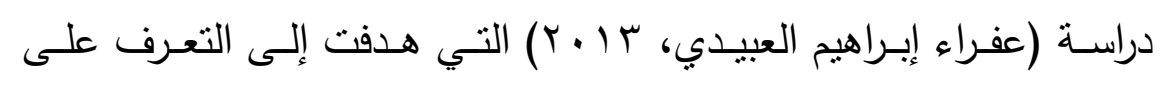

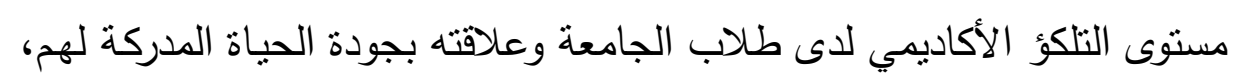

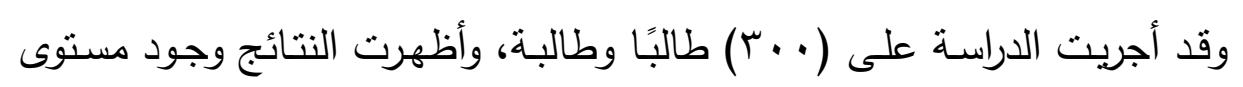


مرتفع من التلكؤ الأكاديمي ومتدني من جودة الحياة، وعدم وجود فروق دالة

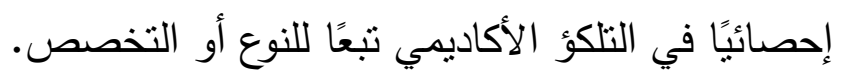

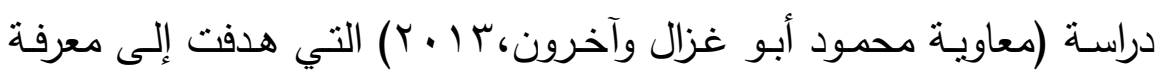
العلاقة بين التلكؤ الأكاديمي بتوجهات الأهداف لدى طلاب الجامعة، وقد أجريت

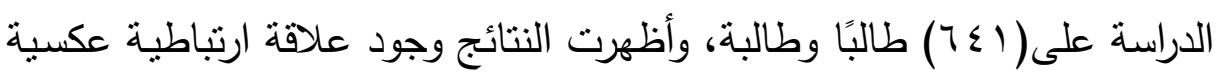

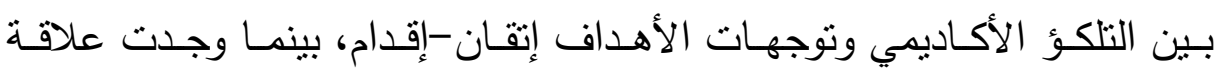
ارتباطية طردية بين التلكؤ الأكاديمي وتوجهات الأهداف أداء-تجنب. الأهن

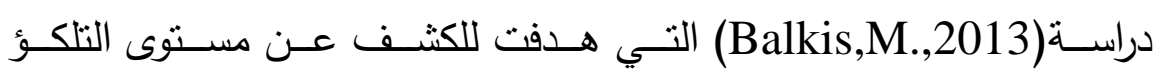
الأكاديمي لدى الطلاب، وعلاقتها بالمعنقدات العقلانية، وقد أجريت الدراسة على ماتى

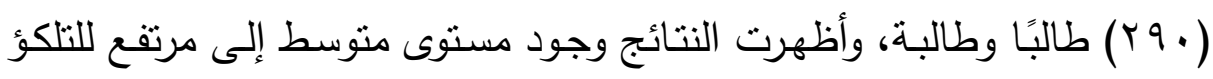

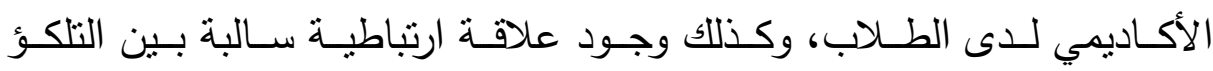
الأكاديمي وكل من المعتقدات المعرفية والتحصيل.

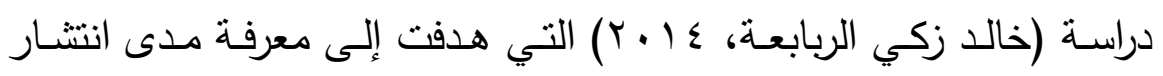

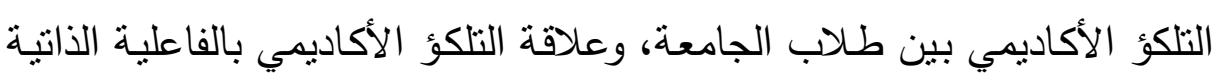

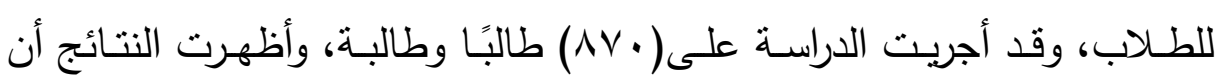

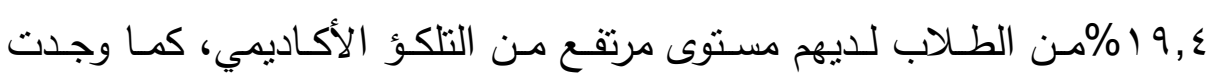

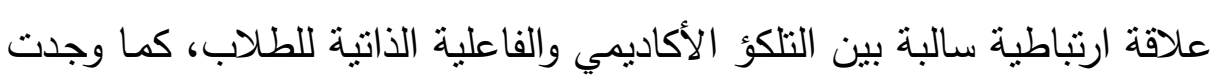

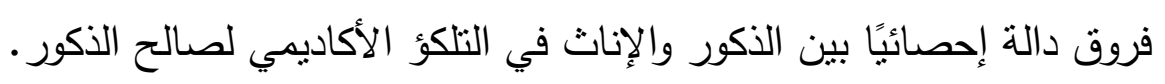

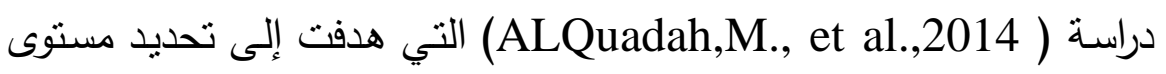
التلكؤ الأكاديمي لاى طلاب الجامعة وكذلك معرفة الفروق في التلكؤ الأكاديمي

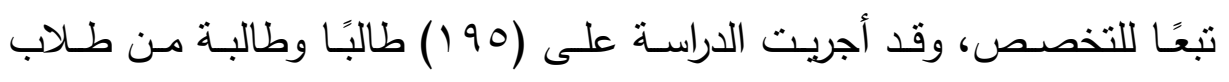

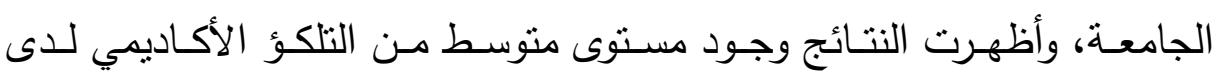
الطلاب، وكذلك علاقة ارتباطية سالبة بين التلكؤ الأكاديمي والتحصيل الدراسي وني

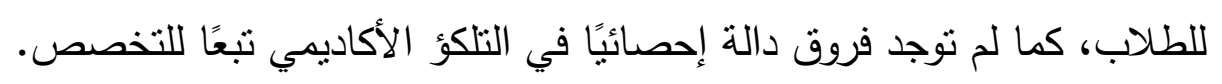


دراسـة (Kandemir,M.,2014) التـي هـدفت إلى معرفـة إمكانيـة التتبؤ

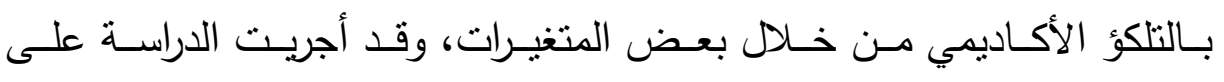

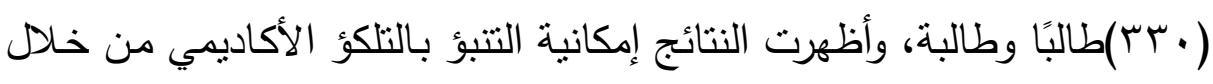
بعض السمات الثخصية وأساليب العزو السببي والمعتقدات حول الفاعلية الذاتية الأكاديمية.

دراسة (Khan,M.,et al.,2014) التي هدفت إلى معرفة الفروق في التلكؤ

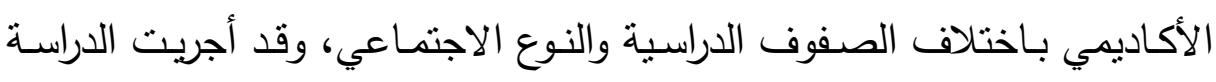

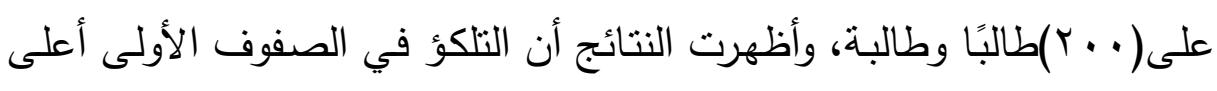
من الصفوف العليـا، وكذللك وجـود فروق دالـة إحصـائيًا بين الذكور والإنـاث

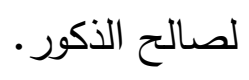

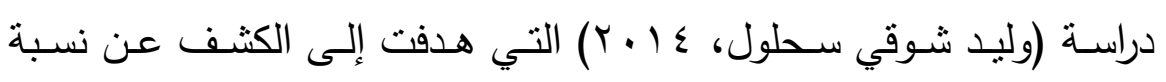

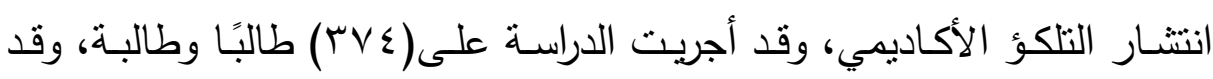

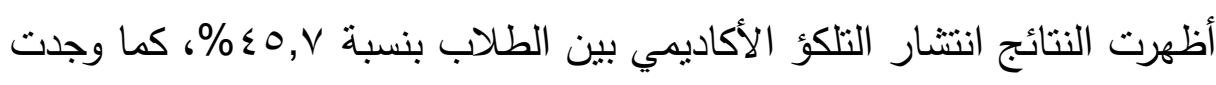

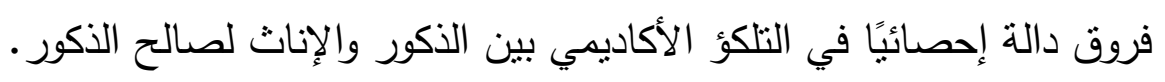

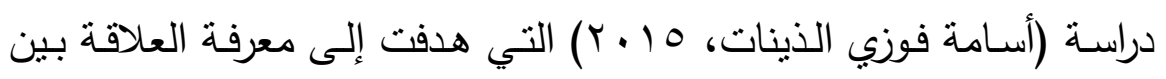

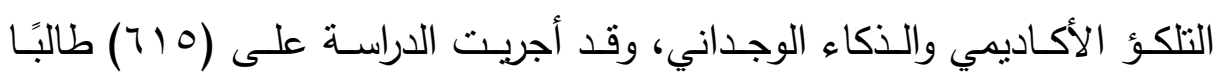

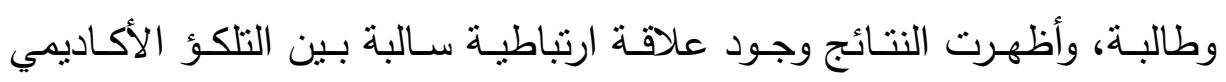

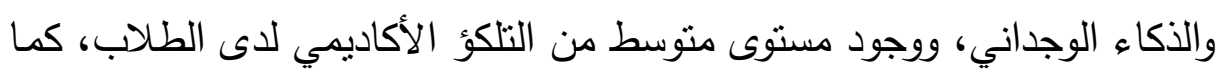
وجدت فروفًا ذات دلالة إحصائية في التلكؤ الأكاديمي لصالح الإناث. دراسة (Toker, B. \& Avci, R., 2015) التي هدفت إلى التعرف على الإنى

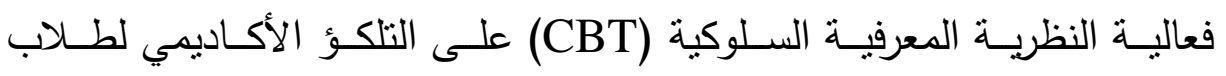

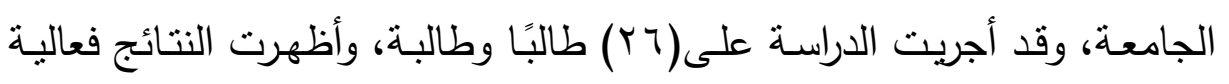

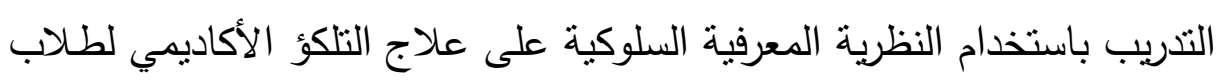
الجامعة. 
دراسـة (لينـة أحمد الجنادي، وابتسام محمود عمر، 10 ب ب) التي هدفت إلى

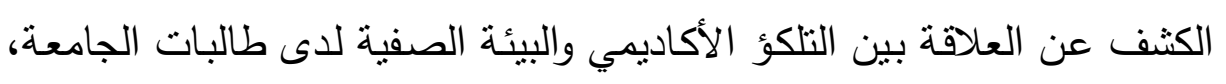

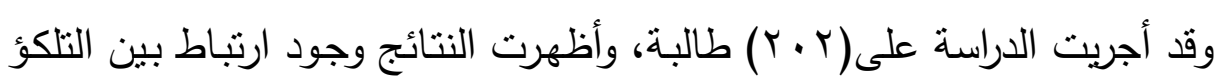

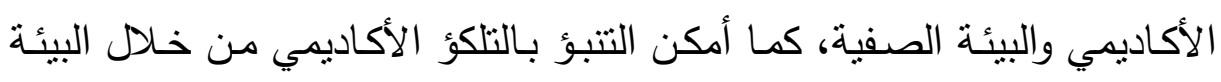
الصفية.

دراسة (هناء صالح شبيب، 10 • ب) التي هدفت إلى الكثف عن نسبة انتشار

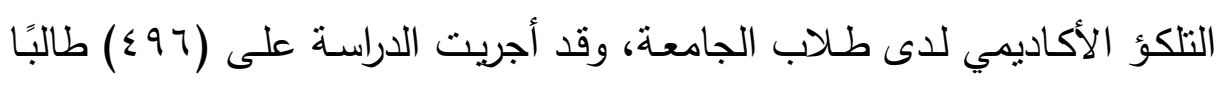

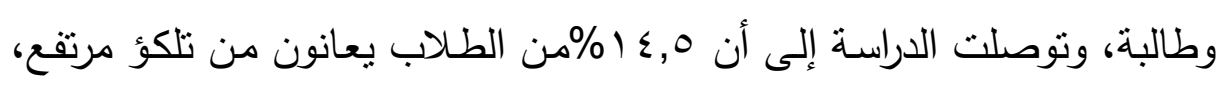

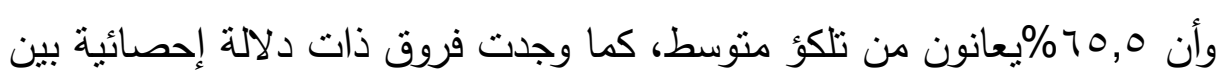

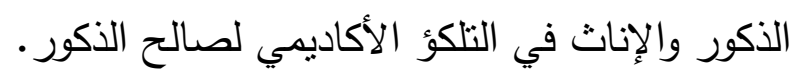

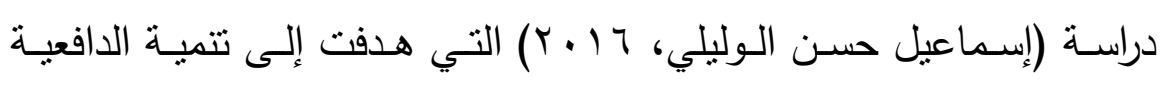

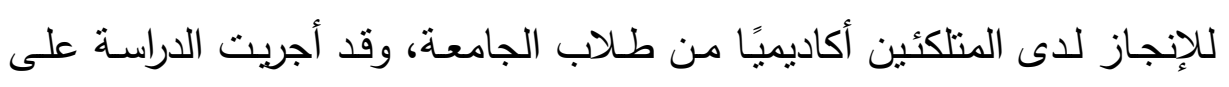

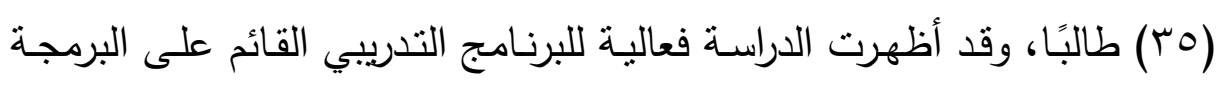
اللغوية العصبية في تتمية دافعية الإنجاز لاى المتلكئين أكاديميًا.

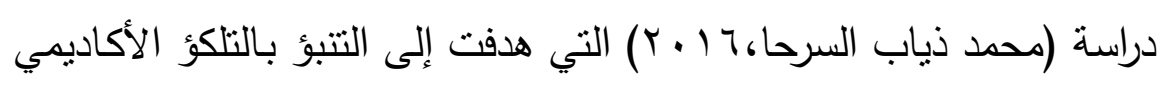

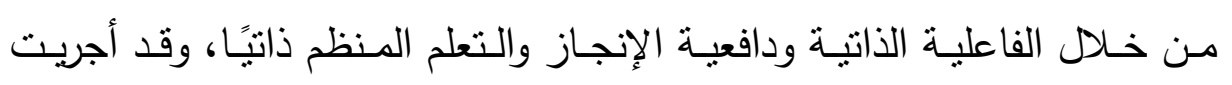

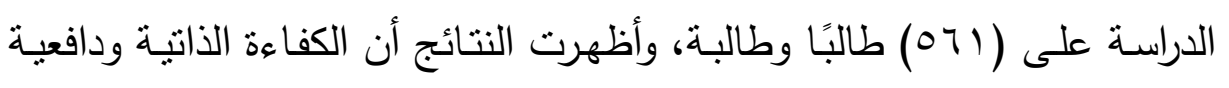

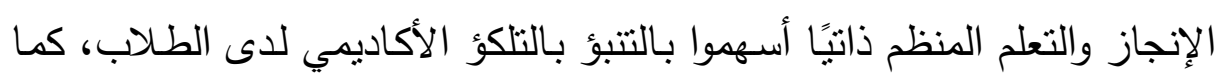

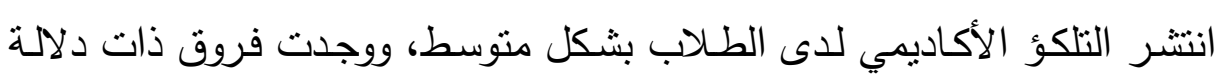
إحصائية في التلكؤ الأكاديمي بين الذكور والإناث لصالحي لإلح الذكور.

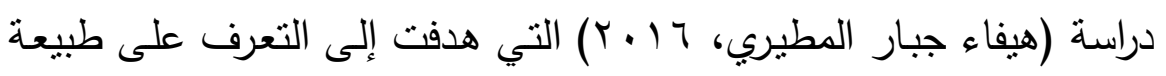

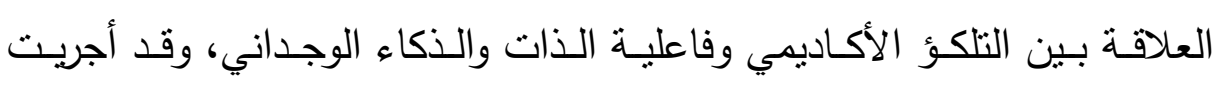

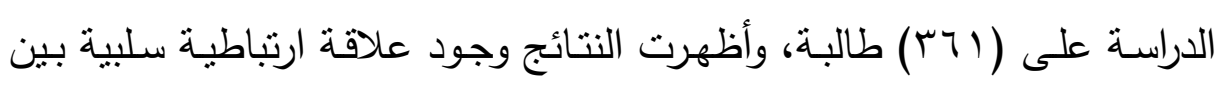

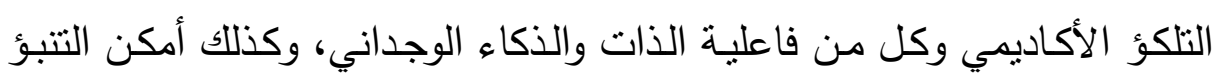

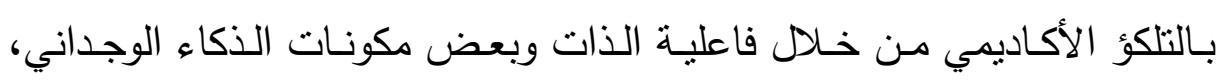


ووجدت فروق دالة إحصائيًا في التلكؤ الأكاديمي بين الأقسام العلمية والأدبيـة لصالح الأقسام العلمية. دراسة (Yerdelen,S.,et al.,2016) التي هدفت إلى التعرف على طبيعة العلاقة بين التلكؤ الأكاديمي والفاعلية الذاتية لدى طلاب الجامعة، وقد أجريت

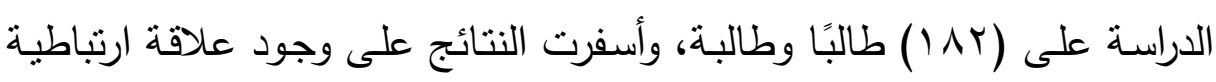

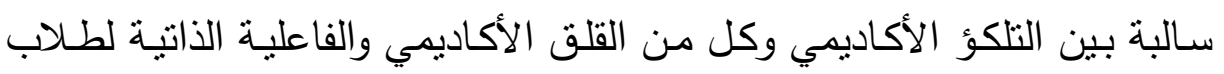
الجامعة.

دراسـة (Yockey,R.,2016) التي هدفت إلى التأكد من صدق وثبات مقياس قصير للتلكؤ الأكاديمي مكون من (خمس مفردات)، وقد أجريت الدراسة

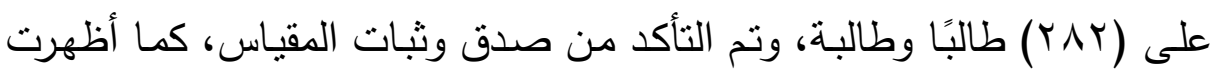

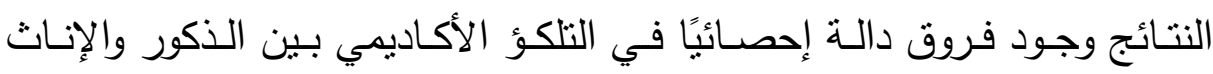

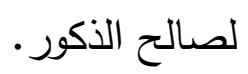
ونظرًا لكثرة عدد الدراسات، فنشير هنا لبعض الدراسات التي تتاولت الفروق

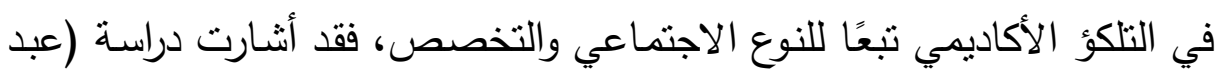

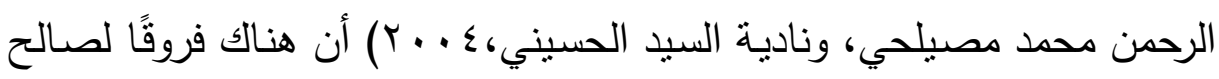

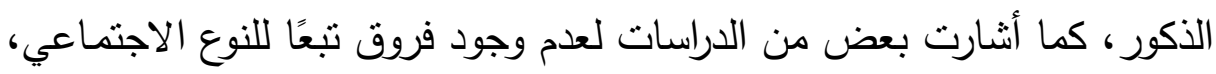

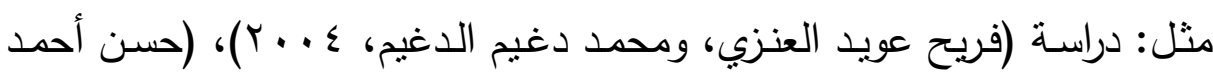

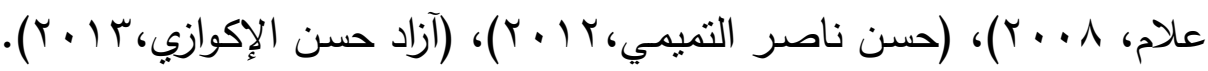

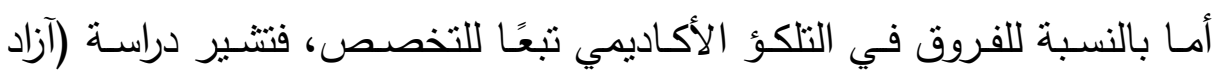

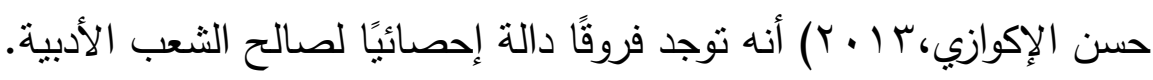
من خلال عرض لبعض الدراسات لمتغير التلكؤ الأكاديمي، وجد أن الباحثين

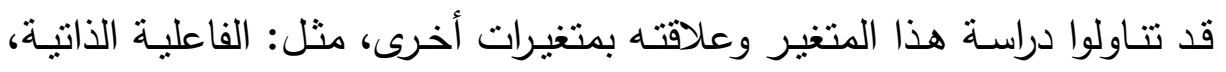

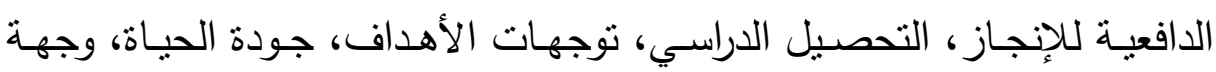

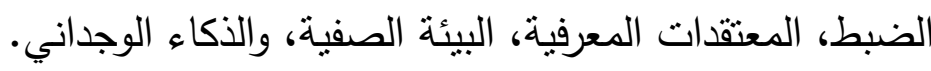


كما تتاولتهـ دراسـات أخرى مـع الكمالية، سـمات الثخصية، أسـاليب العزو

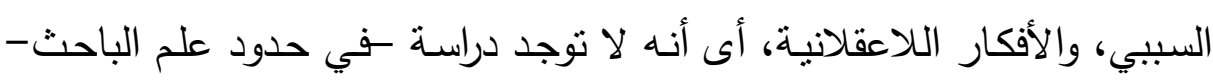

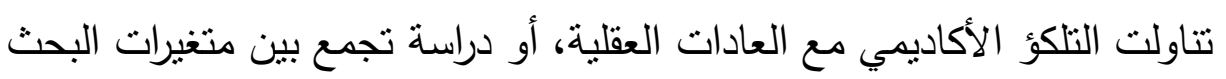
الثثلاثة (التلكؤ الأكاديمي والعادات العقلية والأفكار اللاعقلانية) أو تحديد الإسهام

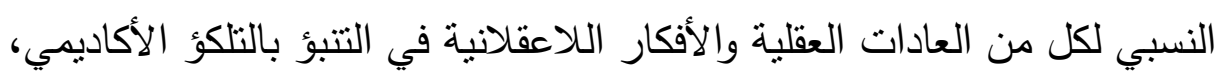

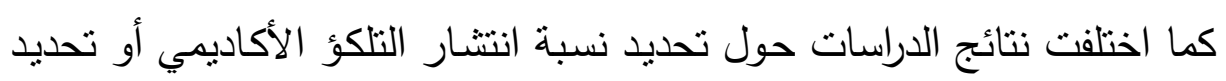

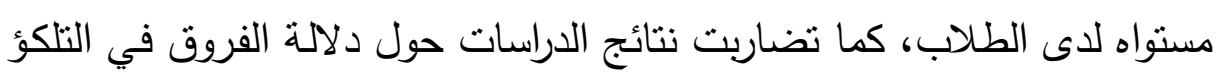

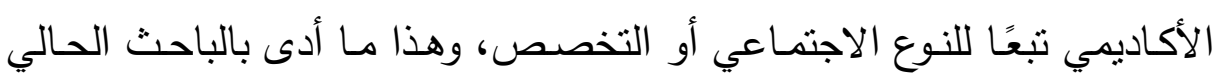

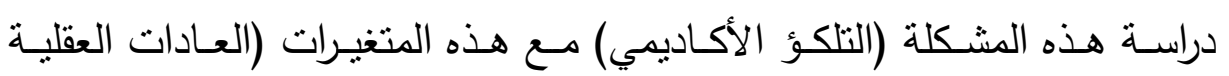
والأفكار اللاعقلانية).

Habits of Mind ثنانيًا: عادات العقل ظهر مصطلح عادات العقل من خلال كتابات Costa \& Kellick في عام

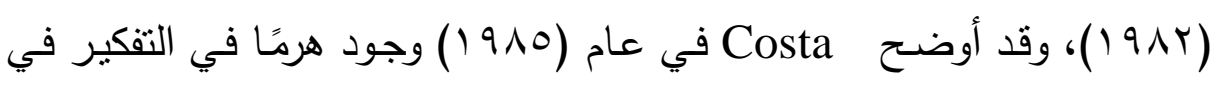
مقاله سلوكيات الذكاء The Behaviors of Intelligence والذي تضمن مفاهيم مهارات التفكير ( المقارنـة- التصنيف- وضـع الفرضيات) واستراتيجيات

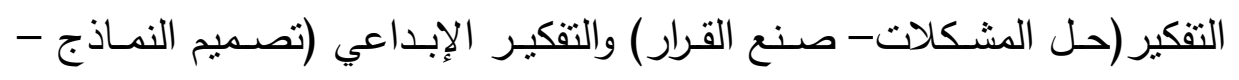

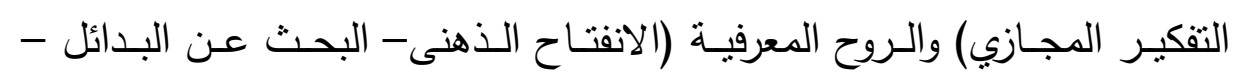

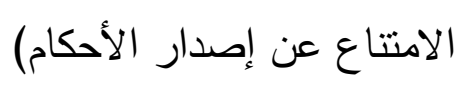

وتعرف عادات العقل على أنها مجموعة من المهارات والاتجاهات والقيم التي التي

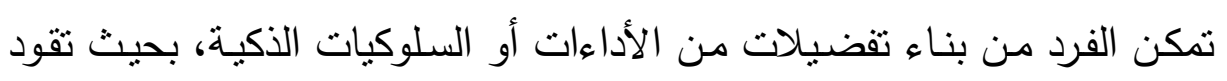

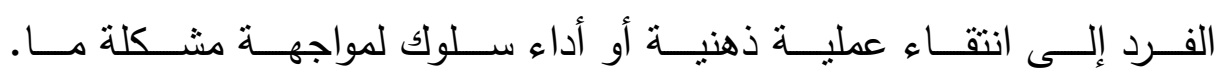

(Regan,B.,1999)

بينما يعرفها (Costa,A.\&Kallick,B.,2000) على أنها مجموعة من المهارات والاتجاهات والقيم والخبرات السابقة، فهي تفضيلات لأنماط من السلوك الفكري. 


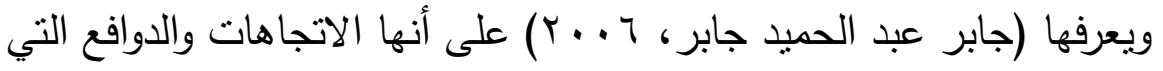

توجها الطالب لاستخدام مهارات عقلية محددة لمواجهة المشكلات، مما يجعلها سلوكًا متكررًا يظهر في مواجهة المواقف المختلفة. وتعرف العادات العقلية على أنها اتجاه عقلي لدى الفرد يحدد سمة مميزة لنمط سلوكياته، معتمدًا على قدرة الفرد على توظيف خبراته السابقة، والاستفادة منها في تحقيق الهدف المطلوب. (صـلاح شريف عبد الوهاب، وإسماعيل حسن الوليلي،

بينما يعرفها الباحث بأنها أنماط عقلية لدى الطالب، توظف مـا لديـه من دوافع لاختيار أفضل السلوكيات التي تساعد على تحقيق أهدافه.

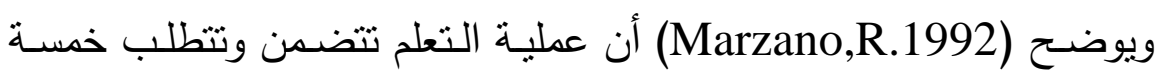
أبعاد من التفكير (أبعاد التعلم)، وهذه الأبعاد توضح كيف يعمل العقل أثناء عملية

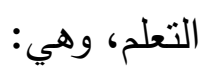

Toward Positive Attitudes Learning الاتجاهات الإيجابية نحو التعلم

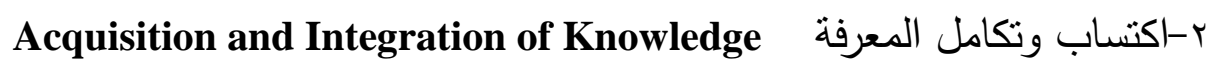
rextending and Refining Knowledge ب-تعميق المعرفة وتقلها Using Knowledge Meaningfully ع -الاستخدام ذات المعنى للمعرفة Productive habits of Mind 0-عادات العقل المنتجة ثم قسم عادات العقل إلى ثلاثة أقسام، وهي:

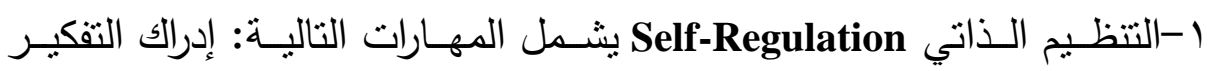

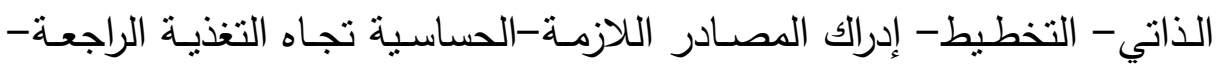
تقويم فاعلية العمل. r-التفكير الناقد Critical Thinking يشمل المهارات التالية: الالنزام بالبحث

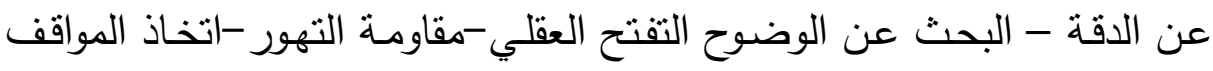
والدفاع عنها-الحساسية تجاه الآخرين. 
r-التفكير الإبداعي Creative Thinking يشمل المهارات التالية: الانخراط في المهمات-توسيع حدود المعرفة-توليد معايير التقييم الخاصة-توليد طرق جديدة خارج نطاق المعايير السابقة. وقد قدما (Costa,A.\& Kallick, B,2000; 2008) قائمة بست عشرة عادة عقلية

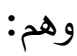

Persisting - 1-المثابرة

Managing Impulsivity التحكم بالتهور ristening with Understanding ب-الإصغاء بتقهم واهتمام بور Thinking Flexibly ع-التفكير بمرونة

Thinking about Thinking ه-التقكير في التقكير Striving for Accuracy 7-السعي من أجل الدقة Questioning and Posing Problems

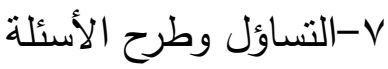
1-تطبيق المعارف الماضية Applying Past Knowledge to new Situation

$$
\text { 9-التفكير والتواصل بدقة ووضوح }
$$

Thinking and Communicating with Clarity and Precision

$$
\text { • }
$$

Gathering data through all The senses

Creating and Imagination

Responding with Wonderment and Awe

Taking Responsible Risks

Finding Humor

Learning Continuously

Thinking Interdependently

$$
\text { | إإبداع والتصور }
$$$$
\text { r ا ب الاستجابة بدهشة }
$$
با بالإقدام على المخاطرة

$$
\text { ع ا-إيجاد الدعابة }
$$

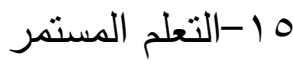
19-التفكير التبادلي

عادات العقل هي نمط حياة بيتخدمها الطالب دون عناء أو تعب، فالعادة العقلية تستخدم في كل مواقفه الحياتية ليست فقط عندما تقابله مشكلة، وعلى هذا لئاه 
فلابد من تدريب وتعويد الطلاب على ممارسـة المهارات العقلية المختلفة، كي تصبح لديهم عـادة. وفي ظل عصر العولمـة والانفجار المعرفي الذي نعيشـهـ والمتغيـرات السـريعة التي تحدث حولنـا، وجب علينـا كمربيين تسـليح طلابنـا بالمهارات العقلية المختلفة وتدريبهر عليها، وبالنظر إلى العادات العقلية الستة عشر نجد أنها مهمة ومطلوبة لأي طالب كي يتوافق مع دراسته ويحقق أهدافه.

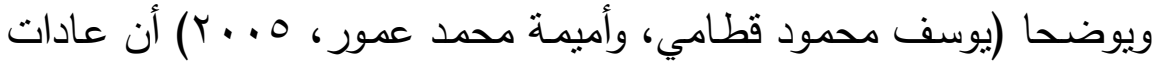
العقل هي نتاج أربع مراحل منتابعة من التفكير، وهي:

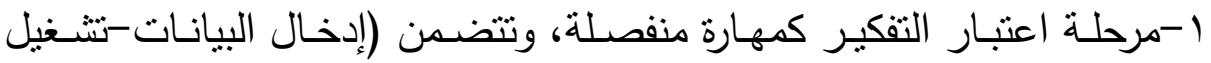
البيانات-استخراج النواتج بعد تطويرها).

ז-مرحلة اعتبار التفكير كاستراتيجية، وتتضمن الربط بين المهارات المنفصلة

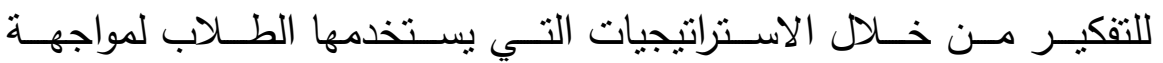
المشكلات، ومنها (حل المشكلات-التفكير الناقد-اتخاذ القرار -الاستدلال - لهن المنطق). r-مرحلة اعتبار التفكير كعملية إبداعية، ويشمل مجموعة من السلوكيات التي

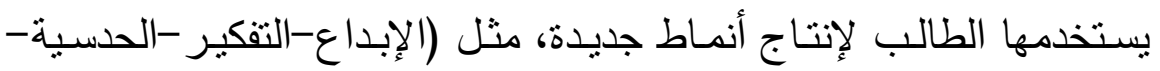
(الاستبصار ).

ع -مرحلة اعتبار التفكير كروح معرفية، وتتمنل في قوة الإرادة والاستعداد والرغبة والالتزام ويتصف صـاحبها بـ (تفتيح الذهن-البحث عن البدائل -التعامل مـع المواقف الغامضة-الاهتمام بالأفكار الرئيسة-الرغبة في التنفيذ). وقد تتاولت بعض الدراسات العربية بعض العادات العقلية وليست العادات

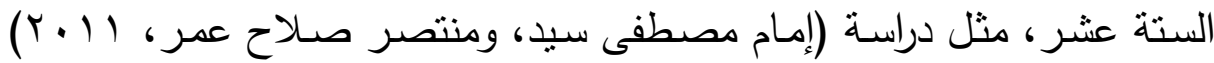
والتي تتاولت عادات عقلية محددة وهي: المثابرة، التقكير في التفكير ، التساؤل وطرح الأسئلة، تطبيق المعارف الماضية، والتقكير والتواصل بوضوح، وكذللك دراسة (يوسف حسن حجيرات، Y ( † ) تتاول ثمان عادات عقلية منها المثابرة التفكير في التفكير - طرح الأسئلة- التفكير التبادلي، أما في دراسـة (إسماعيل 


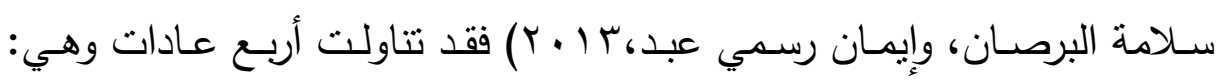

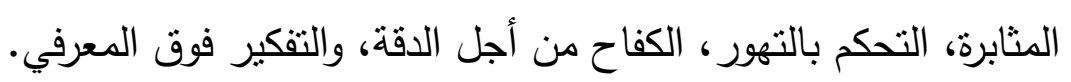

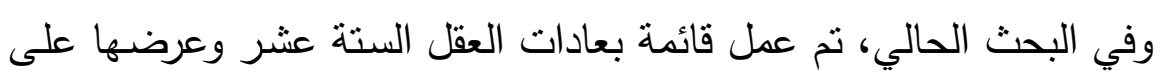

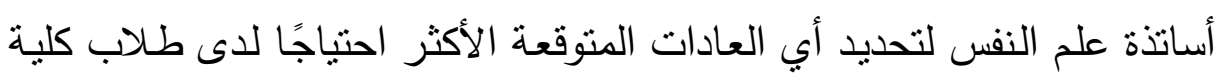
التربية، كما هو موضح خطوات إعداد مقياس عادات العقل، وبالفعل تم تحديد

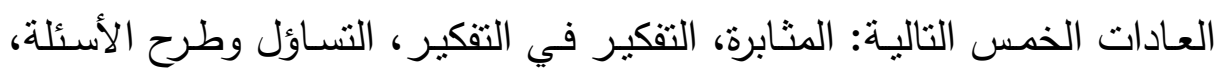
التفكير التبادلي، والسعي من أجل الدقة. وقد اهتمت بعض الدراسات بالعادات العقلية، سواء بالعمل على تتميتها نظرًا لأهميتها في عملية التعليم والتعلم مثل دراسة (Bergman,, D.,2007)، (إيمان

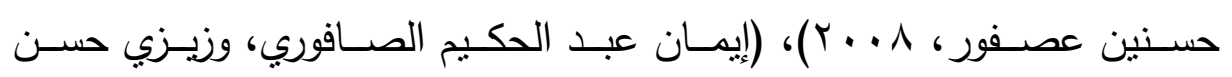

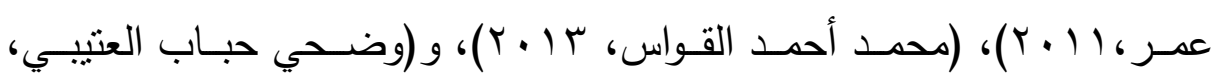

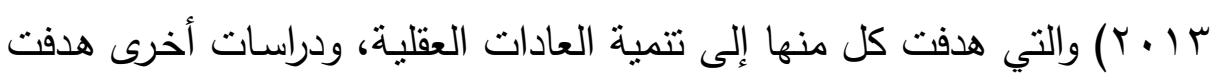

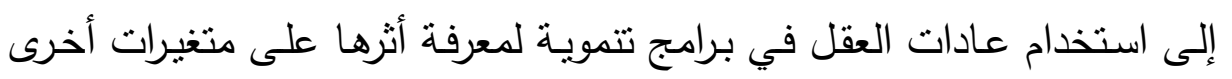

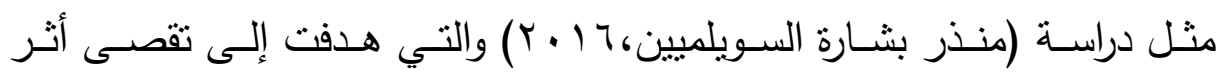
استراتيجية مبنية على تفعيل عادات العقل في تعديل المفاهيم البديلة في العلوم

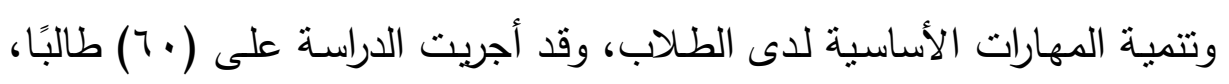

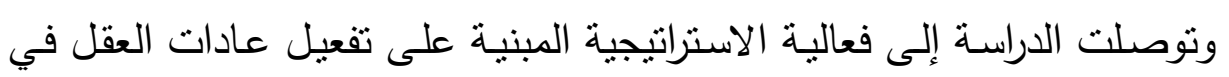
تتمية المهارات الأساسية للطلاب. 
كما تتاولت بعض الدراسات العادات العقلية لطلاب الجامعة وعلاقتها بمتغيرات

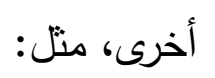

دراسـة (Eva,G.,2002) التي هدفت إلى الكثف عن تأثير عادات العقل على أداء الطلاب من خلال مهام قرائية، وقد أجريت الدراسـة على ( • . ب) طالبًا

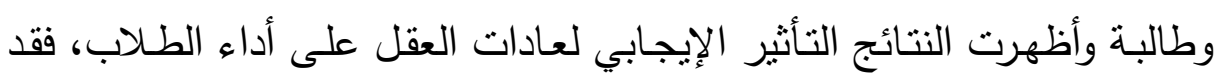
وجد أن الطلاب الذين تلقوا توجيهات فوق معرفية ضمن العادات العقلية كان أداؤهم أفضل من غيرهم.

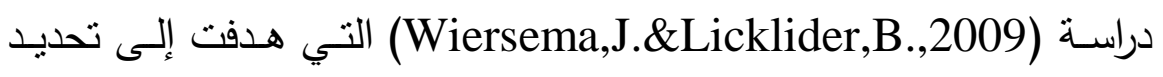
العـادات العقلية لدى الطلاب، وكذللك علاقة هذه العـادات بالتحصيل الدراسي، وقد أجريت الدراسة على(^)طلاب، وأظهرت النتائج أن من أهم العادات العقلية:

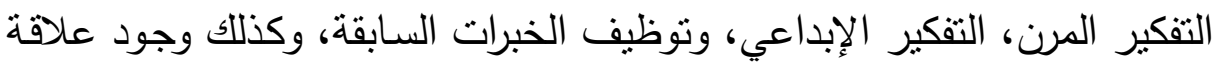
ارتباطية طردية بين العادات العقلية والتحصيل الدراسي.

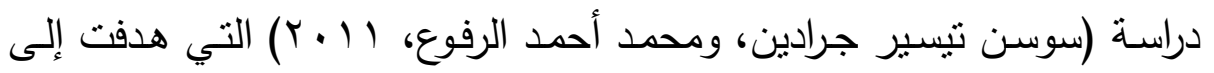

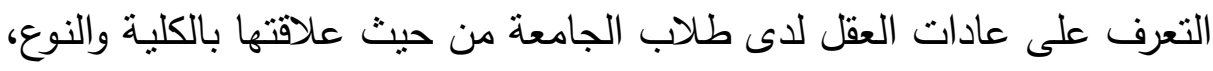

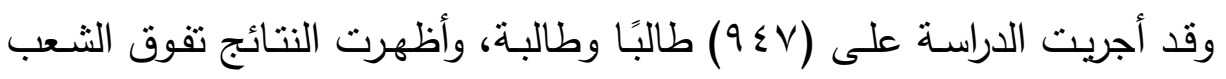

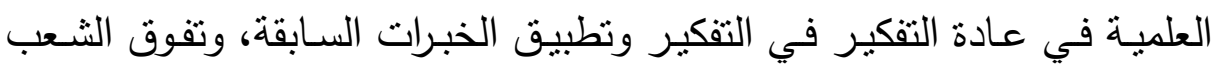

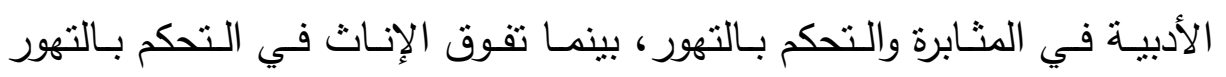
وتطبيق المعرفة السابقة والتفكير التبادلي، بينما تفوق الذكور في عادة المثابرة.

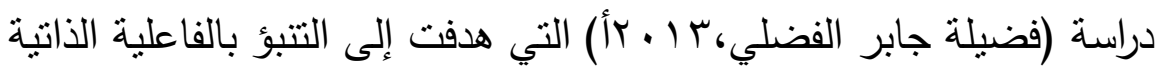

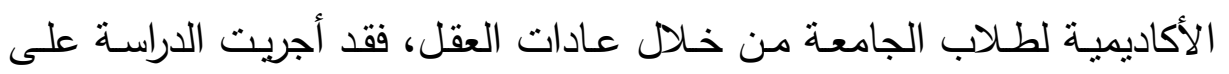

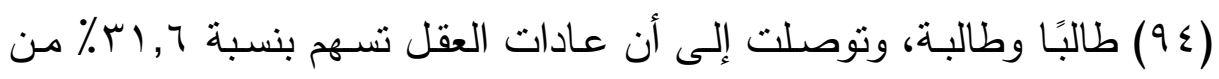

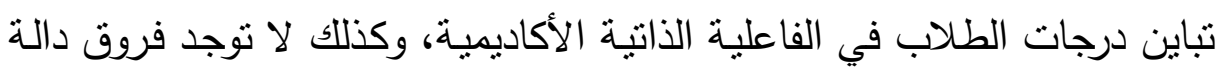

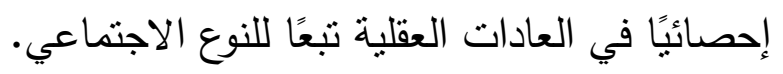

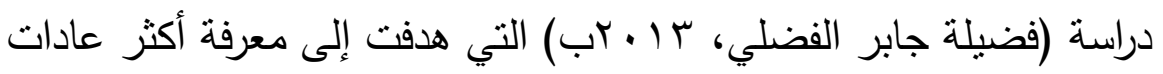
العقل شيوعًا لدى الطلاب، والتي أجريت على (rیr) طالب وطالبة، وأظهرت 
النتائج أن العادات العقلية: التصور والإبداع، التفكير التبادلي، المثابرة، الإصغاء

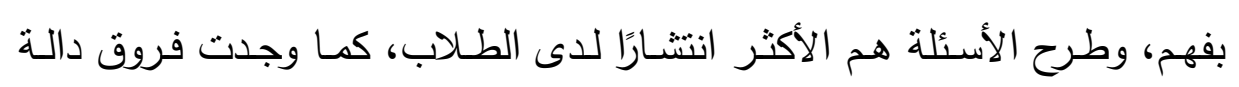

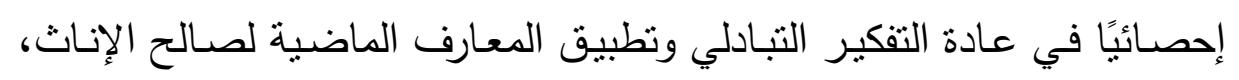
والمثابرة لصاح القسم العلمي.

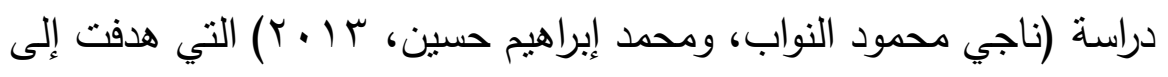

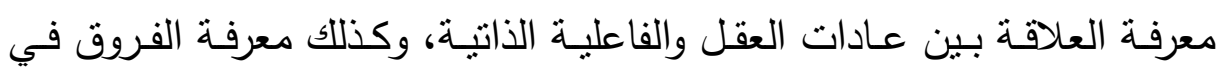

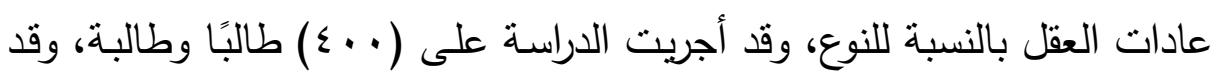

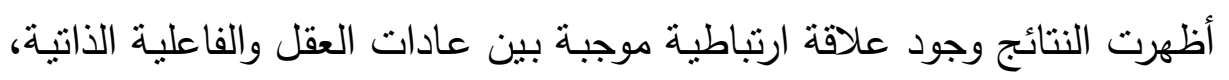

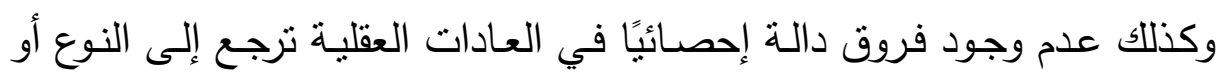
التخصص.

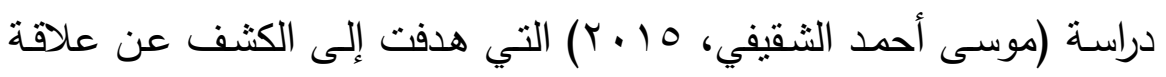

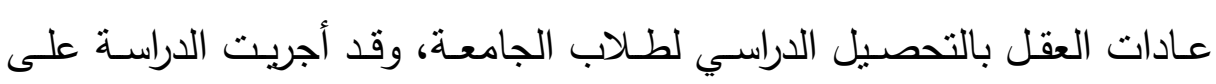

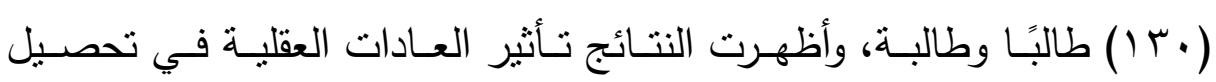

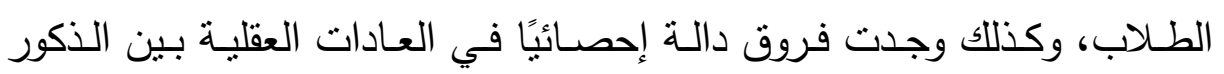
والإناث لصالح الذكور، وعدم وجود فروق دالة إحصائيًا تبعًا للتخصص.

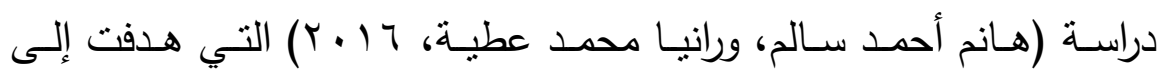

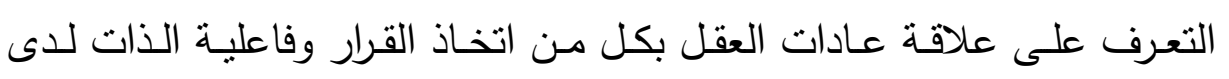

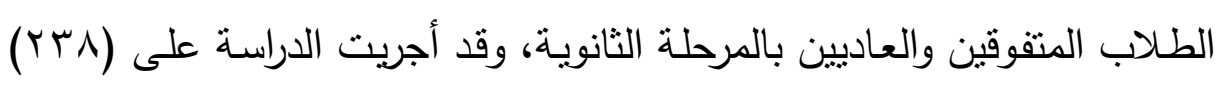

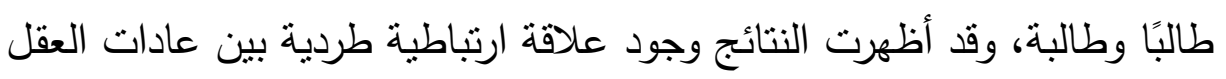

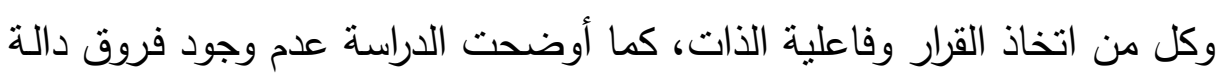
إحصائيًا بين الذكور والإناث في العادات العقلية.

كما وجدت دراسـات أخرى هدفت إلى معرفة الفروق في عادات العقل بين

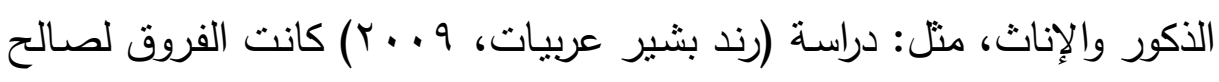

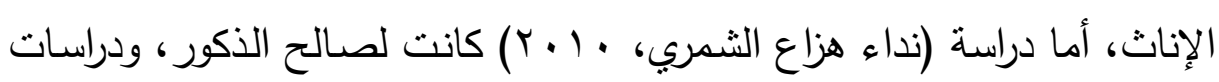
أخرى أثنارت إلى عدم وجود فروق في عادات العقل بين الذكور والإناث، مثل: 


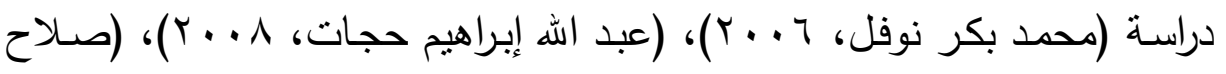

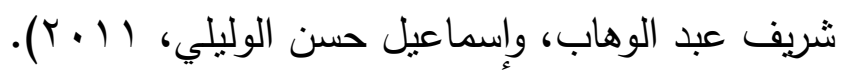

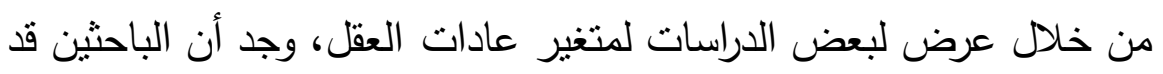

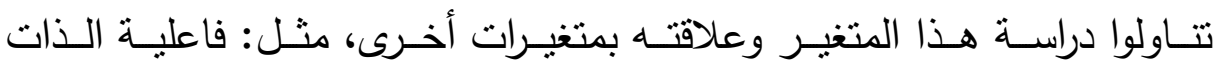

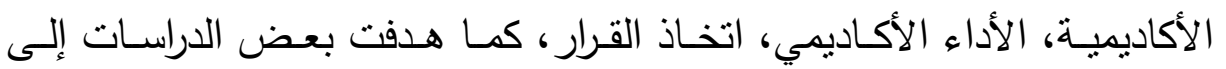

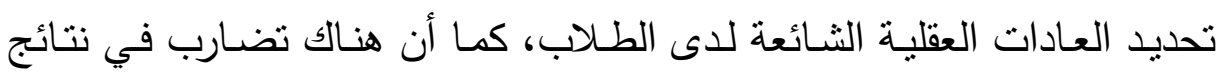

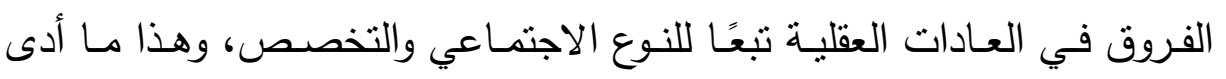
بالباحث في التفكير بدراسـة متغير العادات العقلية وعلاقته بالتلكؤ الأكاديمي

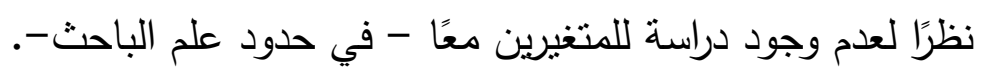

\section{Irrational Thoughts ثالثًا: الأفكار اللاعقلانية}

يعد مفهوم الأفكار اللاعقلانية من المفاهيم القديمة، حيث يعود جذوره إلى آراء

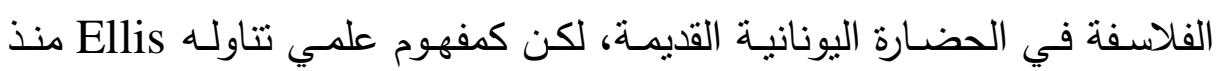
الخمسينات من القرن العشرين. حيث يعرفها (Ellis.,A.,1990) بأنها الأفكار السـالبة وغير المنطقيـة وغير الواقعية، والتي تتسم بعدم الموضوعية والأهواء الذاتية، والمبنية على تععيمات خاطئة، وعلى التهويل والمبالغة.

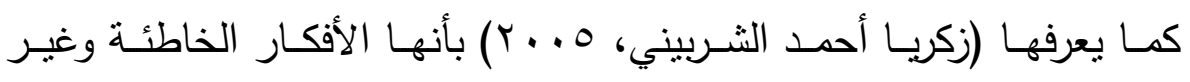
المنطقية التي تتصف بعدم الموضوعية والمبنية على توقعات وتتبؤات خاطئة

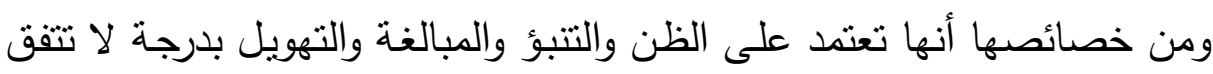
مع الإمكانيات العقلية للفرد. بينما يعرفها الباحث على أنها مجموعة من الأفكار الخاطئة والتي يؤمن بها

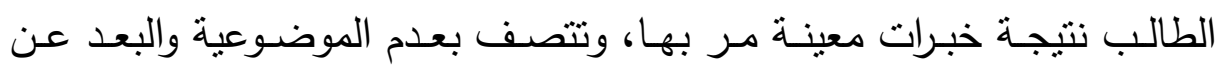
الواقع. يعد Ellis مـن أوائـل البـاحثين الذين أوضـحوا دور الأفكار اللاعقلانيـة في

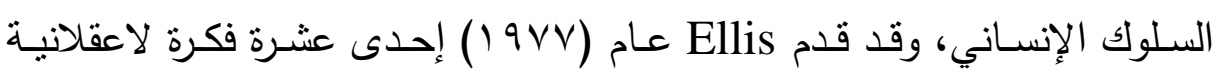


ترجع إلى التشـئة الاجتماعية للفرد وخاصـة في مراحله الأولى، وهذه الأفكار هي: - هي

ا - من الضروري أن يكون الثخص محبوبا أو مقبولا من كل فرد من أفراد بيئته

المحلية، أي تدور هذه الفكرة حول طلب الاستحسان Demand of Approval.

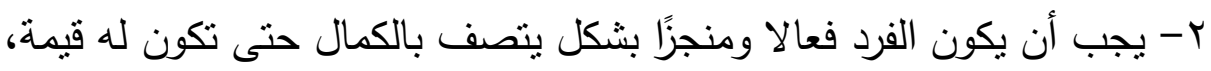

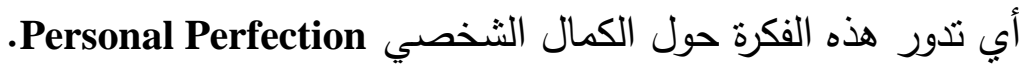
r- بعض الناس سيئون وشـريرون وعلى درجـة عالية من الخسـة والنذالة ولذا

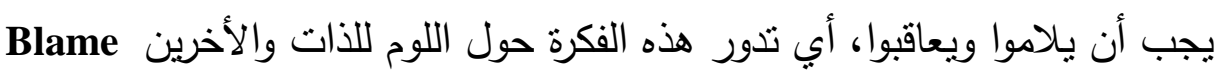

Proneness ؛-إنه لمن المصيية الفادحة أن تأتي الأمور على غير ما يتمنى الفرد، أي تدور هذه الفكرة حول توقع الكوارث Catastrophizing ه-تتشا تعاسـة الفرد عن ظروف خارجية، لا يستطيع السيطرة عليها أو التحكم

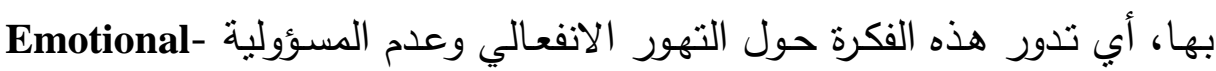
Irresponsibility

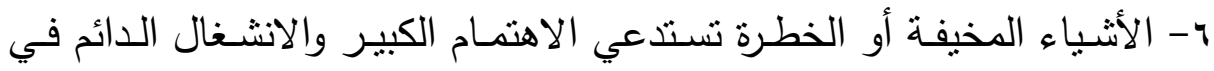

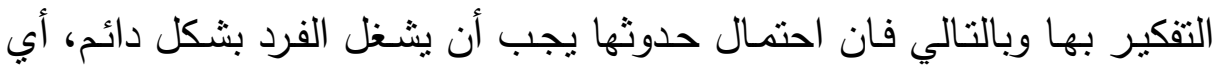
Anxious over تدور هذه الفكرة حول القلق الناتج عن الاهتمام الزائد

Concern

V- من السهل أن نتجنب بعض الصعوبات والمسؤوليات بدلا من أن نواجهها،

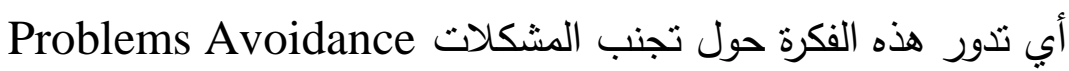
^-يجب أن يكون الثخص معتمدا على الآخرين، ويجب أن يكون هناك من هو هول هون

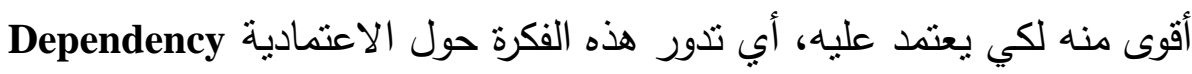

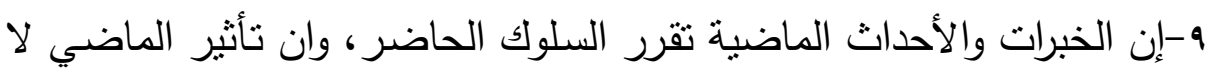

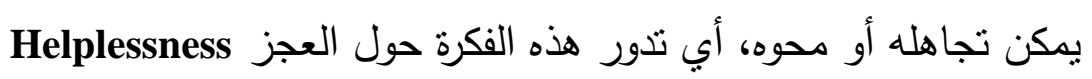




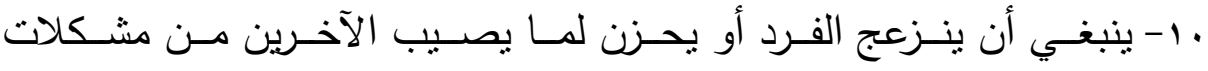

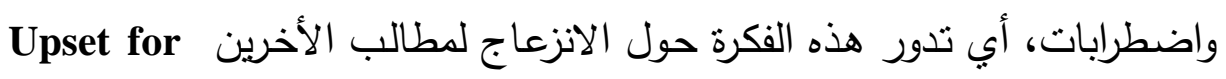
People's Problems 11- هناك دائما حل مثنالي وصحيح لكل مشكلة وهذا الحل لابد من إيجاده وإلا

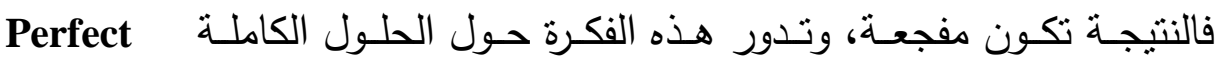
(In: Ellis,A.,1990).Solutions وقد فسر (Ellis,A.,1994) الأفكار اللاعقلانية كأحد مكونات الثخصية للفرد، وأوضـح هذا في نظريته العلاج العقلاني الانفعالي السلوكي، حيث حدد الأند

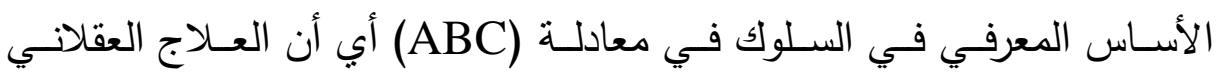
الانفعالي السلوكي يقوم على إقناع الفرد بأن النتائج الانفعالية غير المرغوب فيها النها

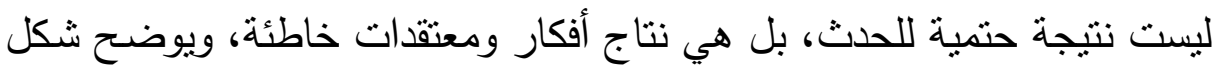
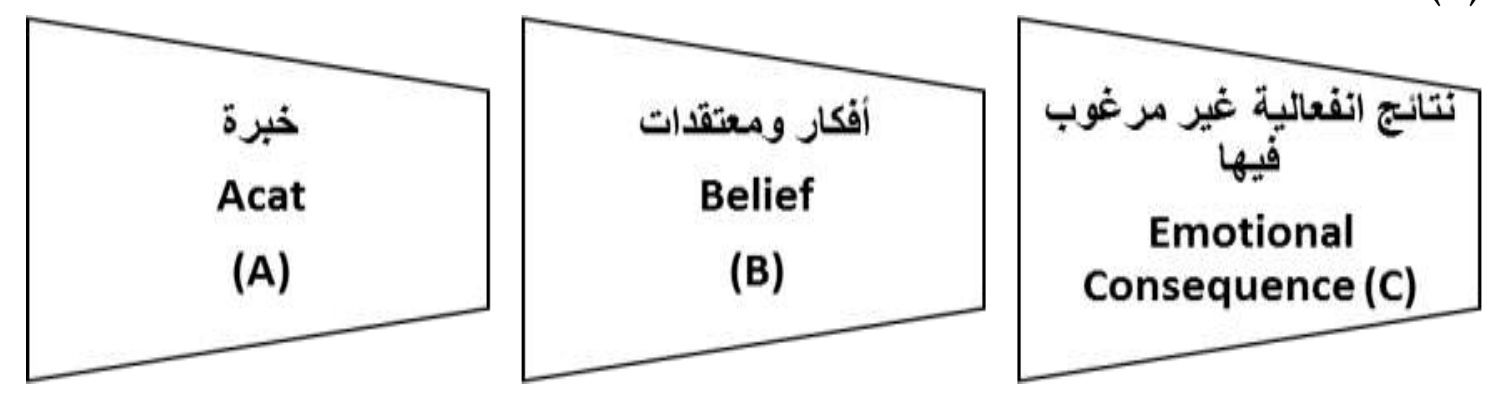

شكل( () الأساس المعرفي للسلوك عند Ellis وقد قدم (Ellis, A.,et. al., 2010) امتدادًا لنموذج (ABC) ليشمل مفهوم معالجة المعلومات، وتغير اللاعقلانية بتغير الهيكلة المعرفية للفرد، كما تحدثوا عن تأثنير الأفكار اللاعقلانية في الأداء البيولوجي للفرد.

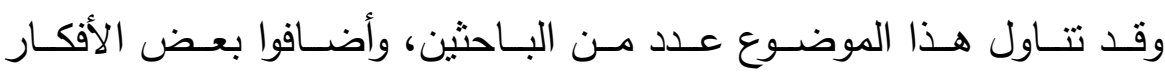
اللاعقلانية، فقد أضاف (سليمان طعمة الريحاني، 9Av I I ) فكرتين هما: ا-ينبخي أن يتسم الثخص بالرسمية والجدية في تعامله مع الآخرين حتى تكون

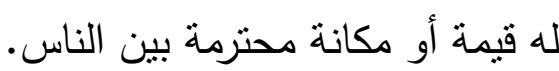
r-لا شك في أن مكانة الرجل هي الأهم فيما يتعلق بعلاقته مع المرأة. 
كما أضاف (عبد الستار إبراهيم، ـ99 (1) فكرة أخرى هي: أن هنالك مصدرًا

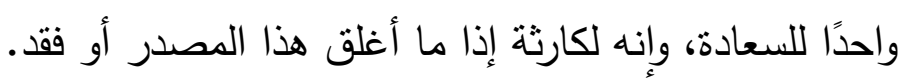
كما أضاف (محد صهيب مزنوق، 997 (1) فكرتين وهما:

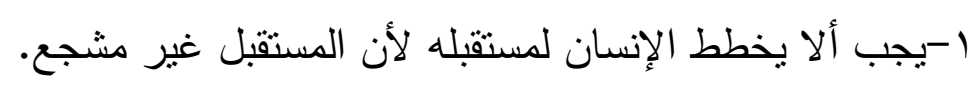

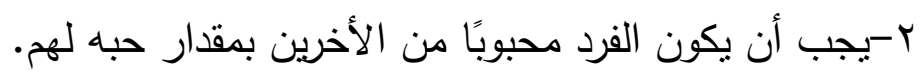
كذلك أضاف (عبد الهه عثمان أحمد، ع . . r) فكرتين هما: 1-أؤمن بأن النجاح مفتاحه الحظ. r-أؤمن بأن الحظ يلعب دورًا كبيرًا في مشكلات الناس أنسا وتعاستهم. كما أضاف (زكريا أحمد الثربيني، 0 . . ץ) ثنلاث أفكار لاعقلانية، هي: ا-بنبغي أن نؤدي جميع أعمالنا بشكل رائع، أي بطريقة ترضي الجيان الجميع.

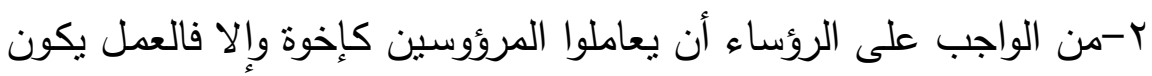
شاقًاً. r-إذا لم يعط الزميل ما أراده زميله منه، فهو شخص غير ذي قيمة ويجب الابتعاد عنه قدر الإمكان. وقد صنفت (سناء حامد زهران، ؟ . . ب) الأفكار اللاعقلانية إلى عدة تصنيفات وفقًا لعدد من المجالات، نذكر منها ما يلي:

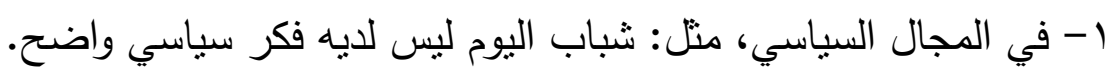

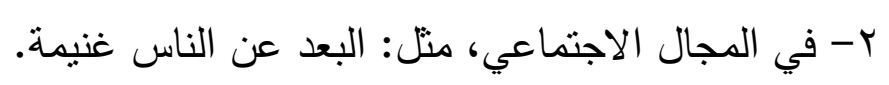
r- في المجال الاقتصادي، منل: الفن هو الطريق السريع للنزاء.

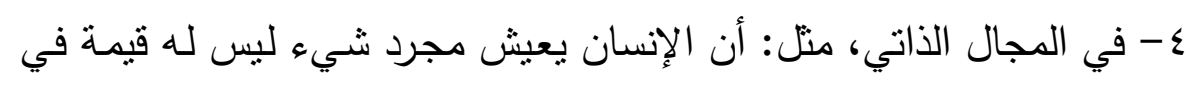
الحياة. 0- في المجال الثقافي، مثل: من يحصل على جنسية أجنبية يكون سعيد الحظ. 
وعلى هذا ليس هناك تحديد مطلق للأفكار اللاعقلانية التي يمكن أن بمتلكها

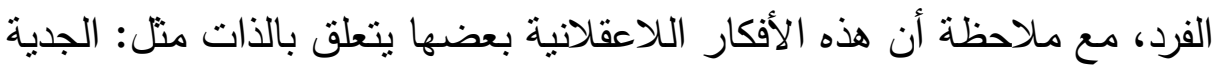

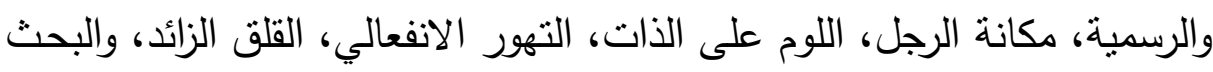

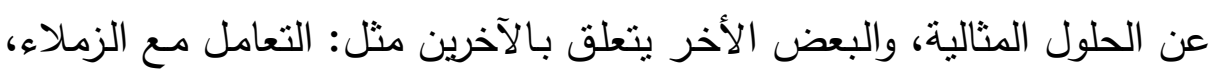

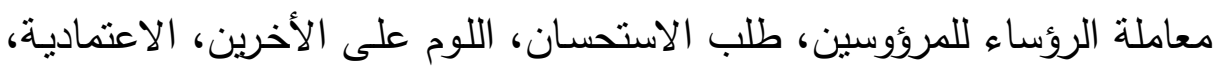

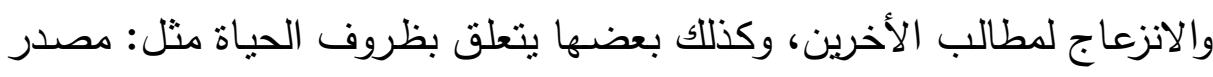

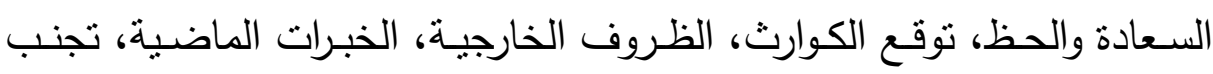
المشكلات.

وتتعدد الأسباب التي تؤدي إلى ظهور الأفكار اللاعقلانية لدى الطلاب، منها

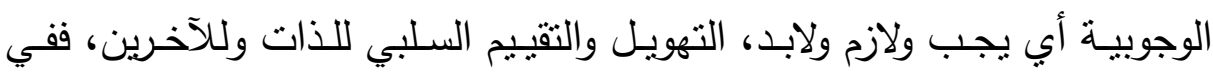

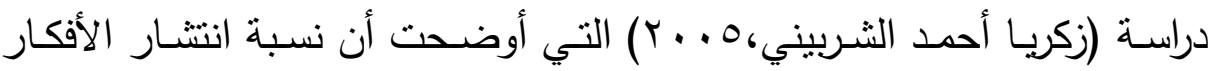

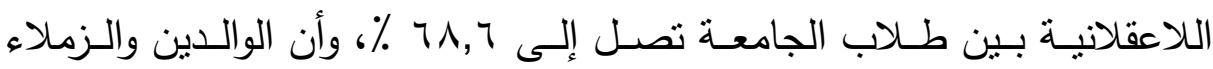

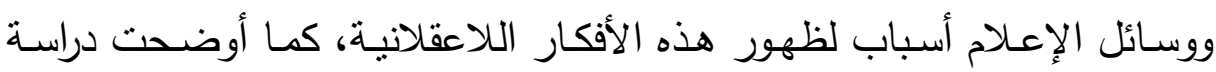

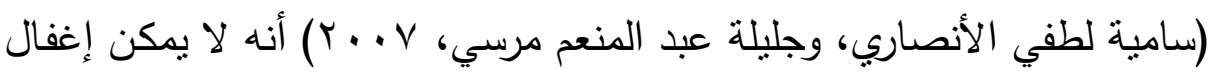
مسؤولية الوالدين من نوعية الأفكار والمعتقدات التي يغرسونها لأبنائهم. أى أن هذه الأفكار اللاعقلانية تظهر منذ مرحلة الطفولة، حيث يكون الطفل

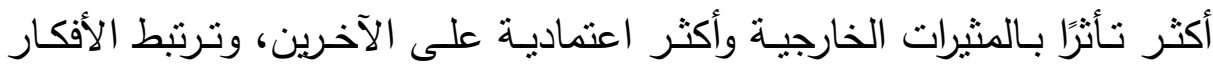

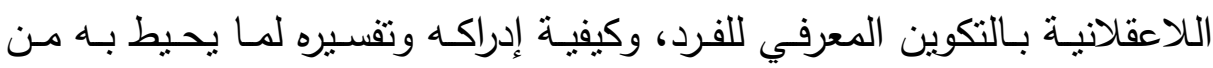
أحداث، وتؤدي لظهور اضطرابات انفعالية وسوء في العلاقات الاجتماعبة. وقد تتاولت العديد من الدراسات متغير الأفكار اللاعقلانية وعلاقته بمتغيرات أخرى ومعرفة مدى انتشار هذه الأفكار لدى الطلاب.

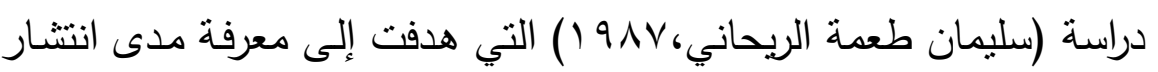
الأفكار اللاعقلانية لدى طلاب الجامعة، وقد أجريت الدراسة على ( . . ع) طالبًا

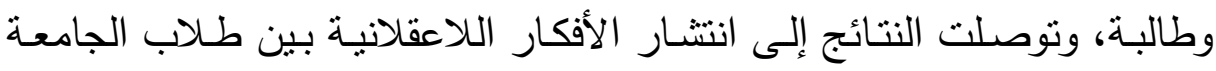

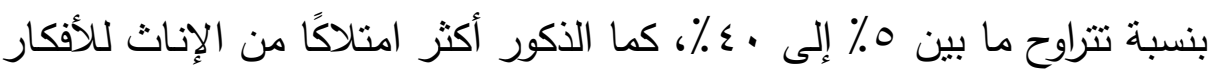


اللاعقلانية، كما أنه ليس هناك أثر للتفاعل بين النوع والتخصص على الأفكار اللاعقلانية.

دراسة (انتصار عبد الرحيم الدويكات، 1991) التي هدفت إلى الكثف عن

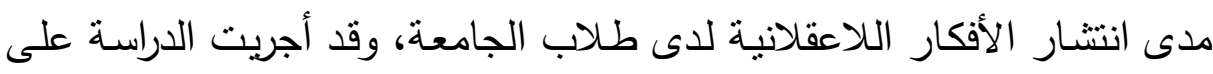

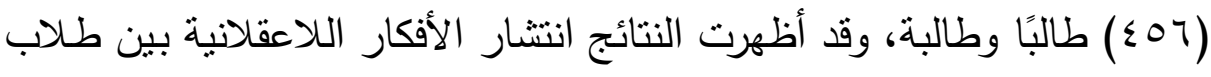

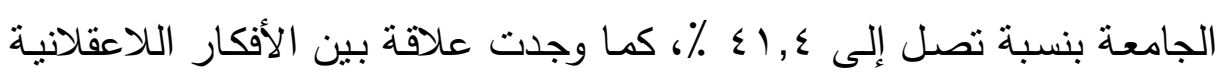
والضبط الخارجي، وتقوق الذكور على الإناث في الأفكار اللاعقلانية.

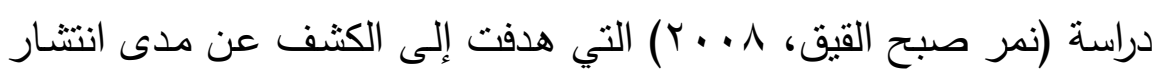
الأفكار اللاعقلانية لدى طلاب الجامعة، وقد أجريت الدراسة على ( ل . . ( ) طالبًا

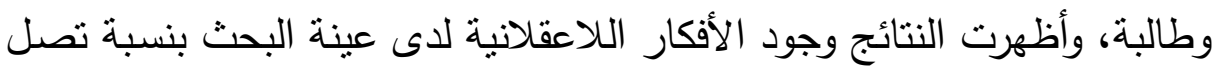
إلى 9ء ٪، كما وجدت فروق دالة إحصائًاً في الأفكار اللاعقلانية بين الذكور

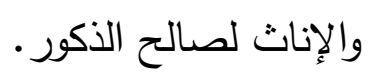
دراسة (Drden,W.\&Sakia,S.,2010) التي هدفت إلى الكثف عن الأفكار اللاعقلانيـة المرتبطة بـالتلكؤ الأكاديمي، وقد أجريت الدراسـة على (79 (9) طالبًا

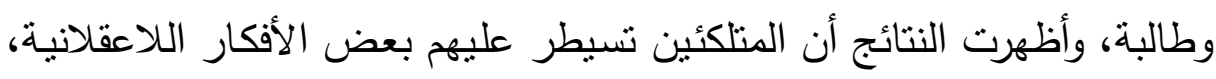
منل : تجنب أداء المهام، الخوف من الفشل، والتردد في اتخاذ القرارات.

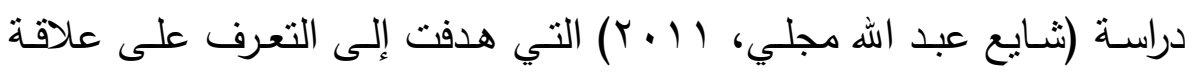
الأفكار اللاعقلانية بالضغوط النفسية، وقد أجريت الدراسـة على ( . . ب) طالبًا وطالبة من كلية التربية، وتوصلت الدراسة إلى وجود علاقة ارتباطية موجبة بين

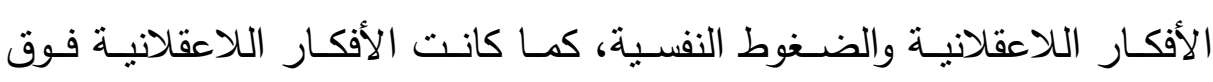
المتوسط، كما وجدت فروق دالة إحصائًًا في الأفكار اللاعقلانية لصالح الذكور .

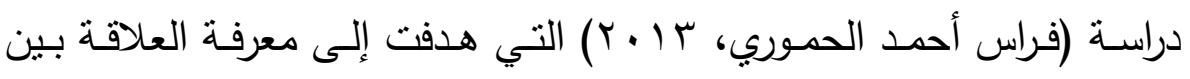
الأفكار اللاعقلانية وأسـاليب التفكير لدى طـلاب الجامعة، وقد أجريت الدراسـة

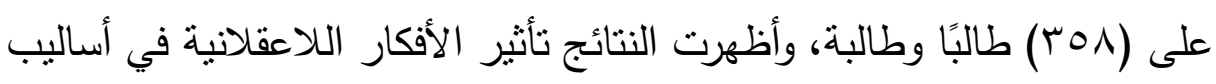




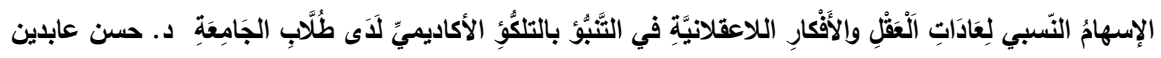

التفكير لـى طـلاب الجامعـة، كمـا لـم توجد فروق دالـة إحصـائيًا بين الذكور والإناث في الأفكار اللاعقلانية.

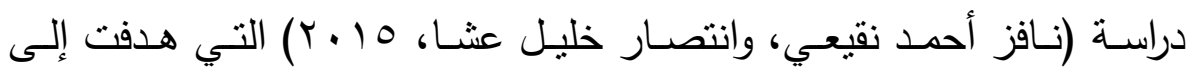

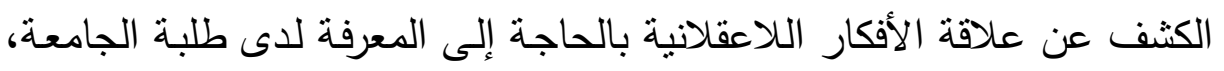

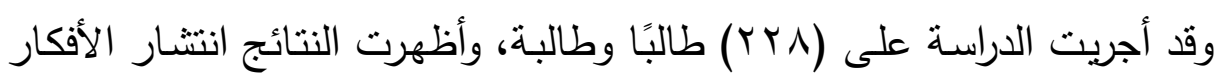

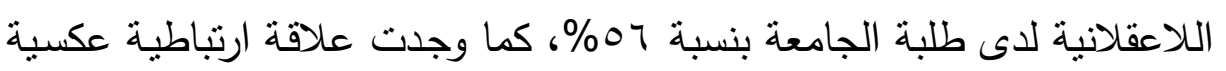
بين بعض الأفكار اللاعقلانية والحاجة للمعرفة، كما وجدت فروق دالة إحصائيًا

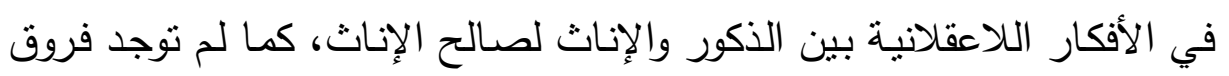

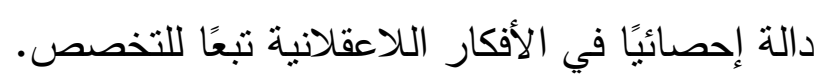
دراسة (Ozer,E.\&Akgun,O.,2015) التي هدفت إلى الكثف عن العلاقة

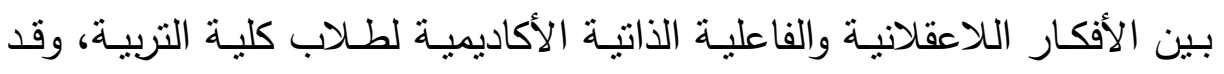
أجريت الدراسة على (17 (1) طالبًا وطالبة، وأظهرت النتائج وجود علاقة ارتباطية

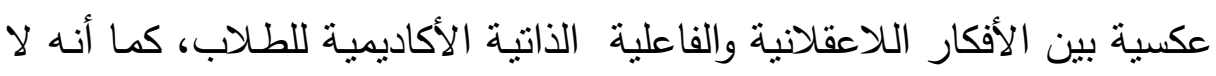
يوجد فروق دالة إحصائيًا في الأفكار اللاعقلانية بين الذكور والإناثة كمـا تتاولت دراسـات أخرى دراسـة الفروق بين الذكور والإنـاث في الأفكار

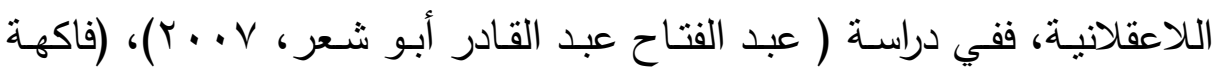

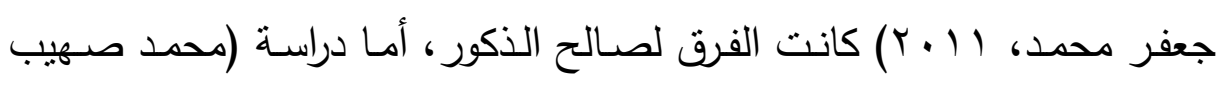

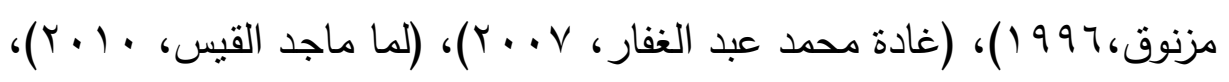

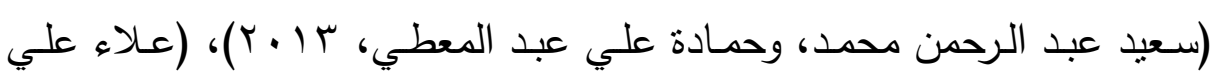

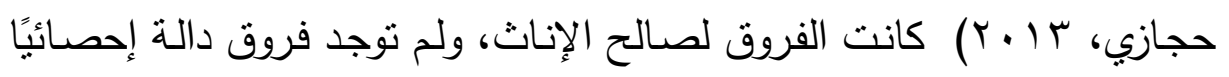

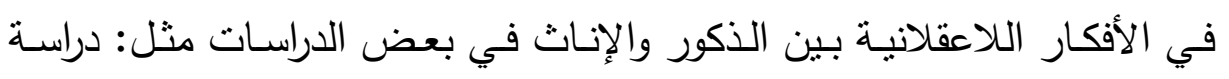

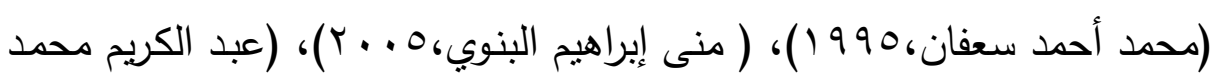

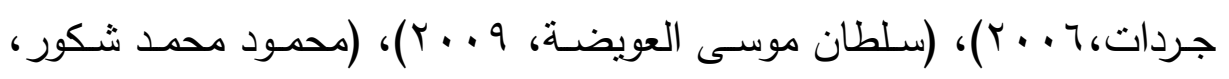

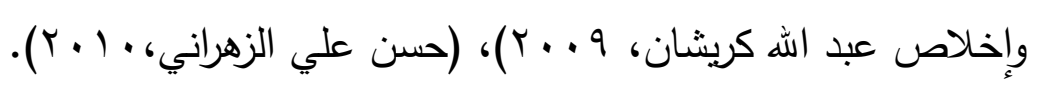


كمـا درست بعض الدراسـات الفروق بـين التخصصـات الأدبيـة والعلميـة في

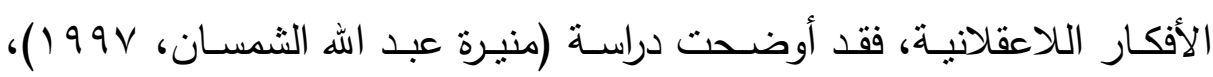

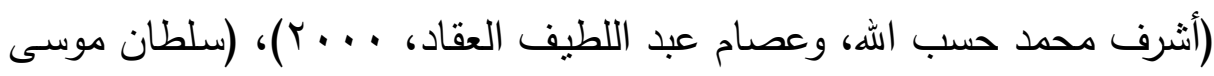

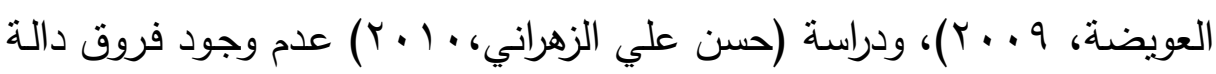

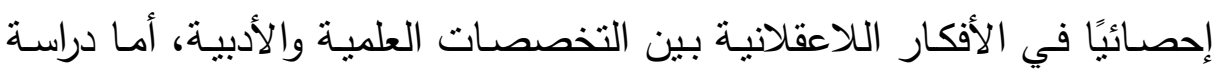

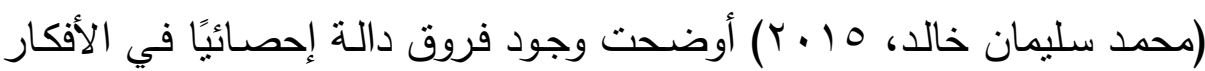
اللاعقلانية لصالح التخصص الأدبي. من خلال عرض لبعض الدراسات التي تتاولت متغير الأفكار اللاعقلانية، فقد

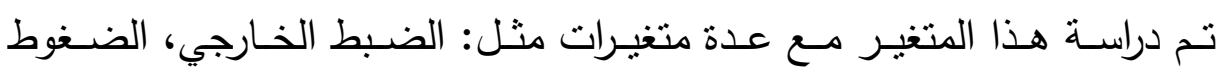

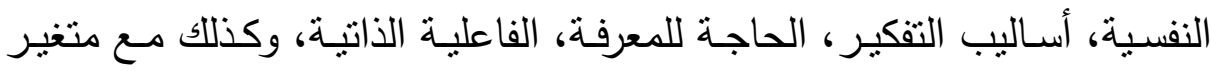
التلكؤ الأكاديمي، كما اختلفت النتائج حول تحديد الفروق في الأفكار اللاعقلانية بين الذكور والإنـاث، ويحاول البحث الحالي التأكيد على العلاقة بين الأفكار

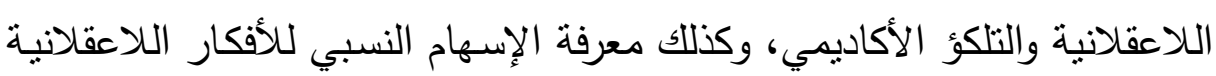
في التنبؤ بالتلكؤ الأكاديمي لطلاب كلية التربية. فروض البحث: 1 - يوجد مستوى متوسط من التلكؤ الأكاديمي لدى طلاب كلية التربية جامعةجامعة الإسكندرية. r- توجد علاقة ارتباطية سلبية بين عادات العقل والتلكؤ الأكاديمي لدى طلاب كلية التربية-جامعة الإسكندرية.

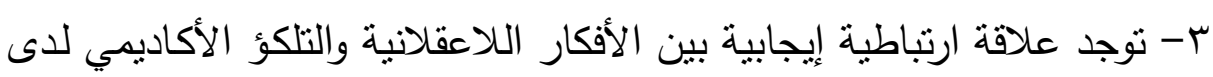
طلاب كلية التربية-جامعة الإسكندرية. ع - لا نوجد فروق دالـة إحصائيًا في عادات العقل للى طلاب كلية التربية-

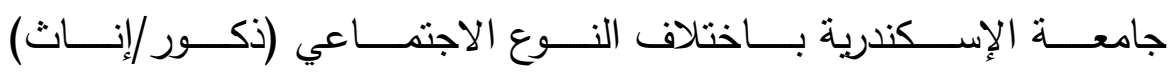
والتخصص(علمي/أدبي) والتفاعل بينهما. 
0- لا نوجد فـروق دالـة إحصـائيًا في الأفكار اللاعقلانيـة لـدى طـلاب كليـة التربيـة-جامعـة الإنــكندرية بــاختلاف النـوع الاجتمــاعي (ذكــور /إنـاث) والتخصص(علمي/أدبي) والتقاعل بينهما.

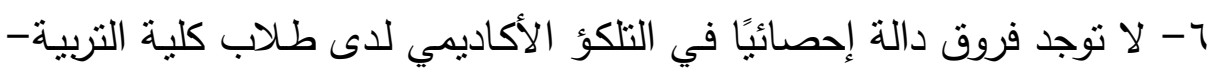

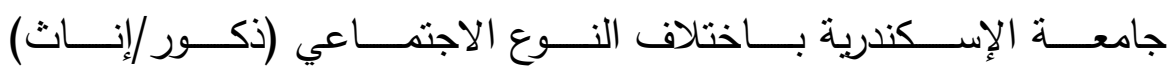
والتخصص(علمي/أدبي) والتفاعل بينهما.

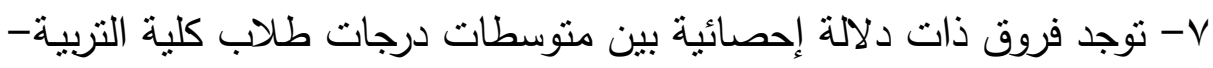
جامعة الإسكندرية مرتفعي ومنخفضي التلكؤ الأكاديمي في عادات العقل. 1- نوجد فروق ذات دلالة إحصائية بين متوسطات درجات طلاب كلية التربية-

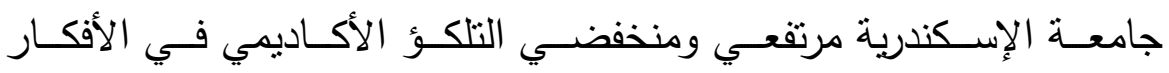
اللاعقلانية.

9- يمكن التتبؤ بالتلكؤ الأكاديمي لدى طلاب كلية التربية-جامعـة الإسكندرية

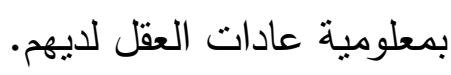
• 1 - يمكن التنبؤ بالتلكؤ الأكاديمي لدى طلاب كلية التربية-جامعة الإسكندرية

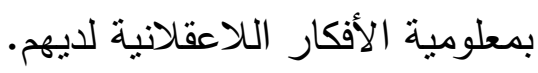

إجراءات البحث:

$$
\text { أ-المشاركون في البحث: }
$$

أ-المشاركون في البحث للتحقق من الخصائص السيكو مترية لأدوات البحث:

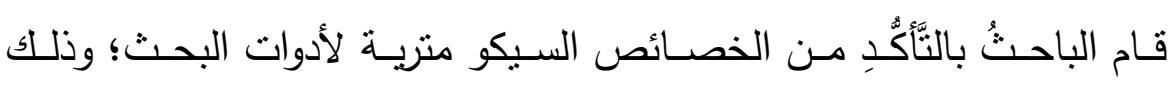

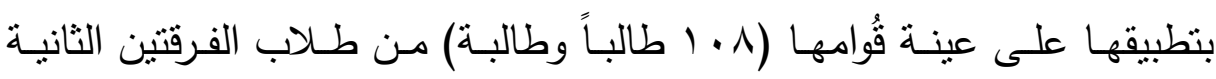

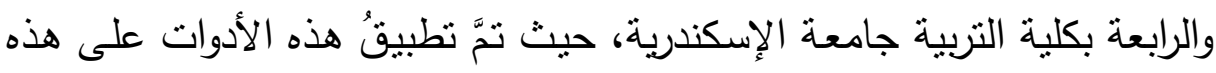
العينة تمهيداً لحساب الصدق والثبات قبل النطبيق على المشاركين في البحث.

$$
\text { ب-المُشََاركُون في البَحْثِ: }
$$

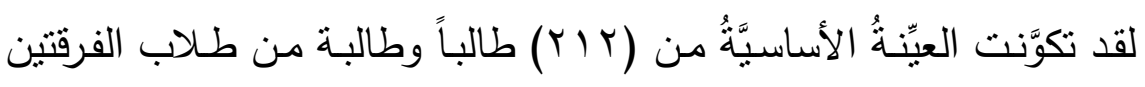
الثانية والرابعة بكلية التربية جامعة الإسكندرية خلال الفصل الدراسي الثاني من 


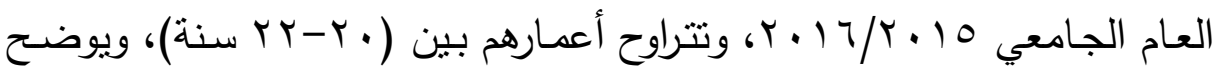
جدول (1) توزيع أفراد العينة حسب النوع الاجتماعي والتخصص.

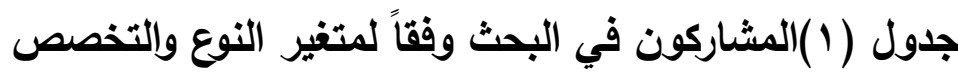

\begin{tabular}{|c|c|c|c|}
\hline المجموع & أدبي & علمي & \\
\hline 91 & or & $\leqslant 7$ & ذكور \\
\hline $11 \varepsilon$ & VI & rA & إناث \\
\hline rir & KK & $\Lambda \varepsilon$ & الدجموع \\
\hline
\end{tabular}

rأدوات البحث:

في ضوء الإطار النظري ونتائج الدراسـات السـابقة قام الباحث بتصميم أدوات

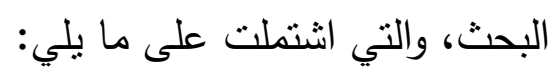

إعداد الباحث

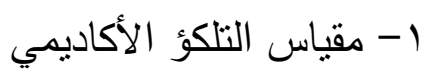

إعداد الباحث

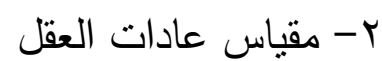

إعداد الباحث

ج- مقياس الأفكار اللاعقلانية وفيما يلي ينم تتاول تللك الأدوات بالتقصيل وعلى التوالي: إعداد الباحث (ملحق التئ )

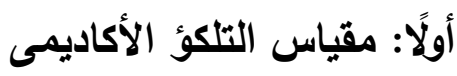

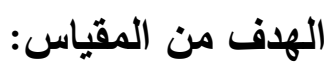
يهدفُ هذا المقياسُ إلى الكثف عن مستوى التلكؤ الأكاديمي لدى طلاب كلية التربية جامعة الإسكندرية.

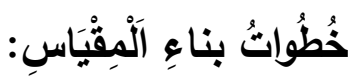

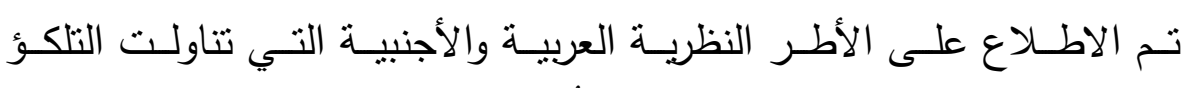

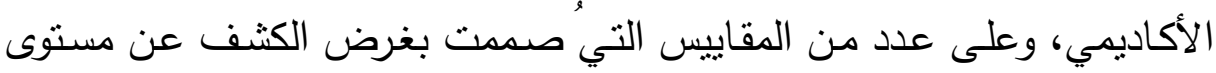
التلكؤ الأكاديمي للطلاب، مثل: مقياس Lay

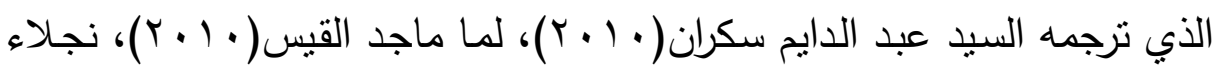

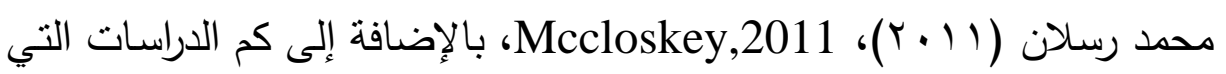
عرضت في الإطار النظري للبحث. وصف المقياس: 
تم صياغة ثلاثون مفردة تقيس التعريف الإجرائي للتنكؤ الأكاديمي " تأجيل

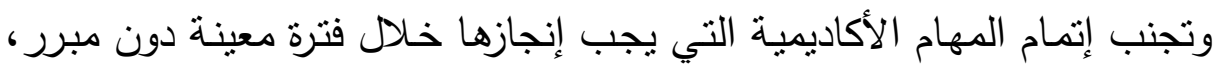

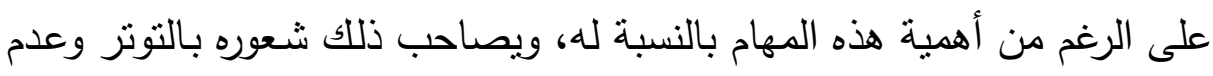

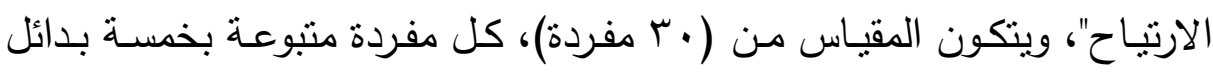

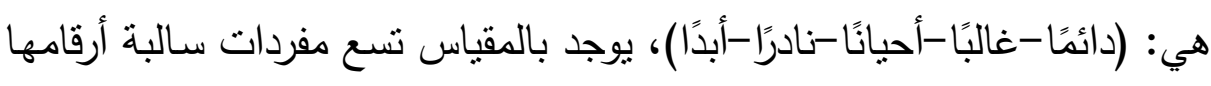

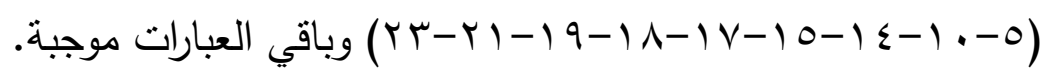
طريقة تقدير درجات المقياس:

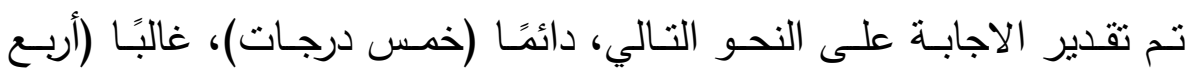

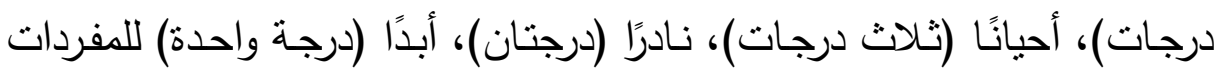

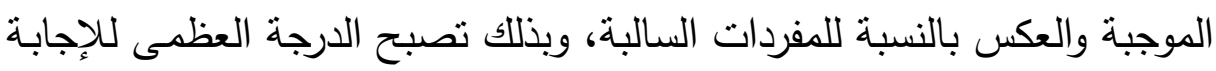

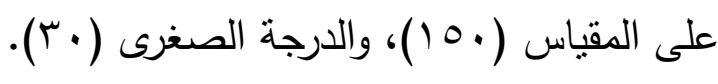

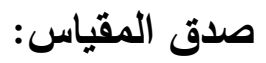
تم حساب صدق مقياس التلكؤ الأكاديمي بثلاث طرق كالتالي:

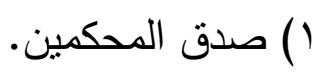
r) (بدق المقارنة الطرفية.

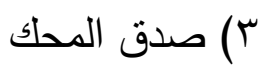


أولاً: صدق المحكمين:

تم عرض المقياس على (^) من السادة المحكمين تخصص علم النفس التربوي

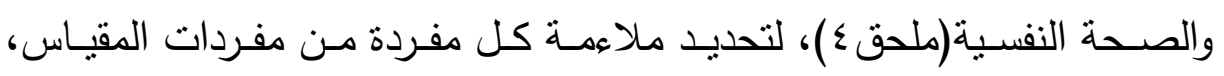

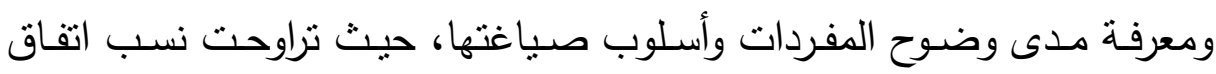

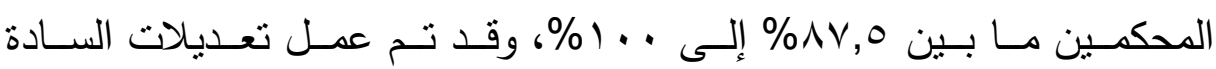
المحكمين. ثانياً: صدق المقارنة الطرفية: قام الباحث بترتيب الدرجات التي حصل عليها الطلاب عينة البحث في مقياس

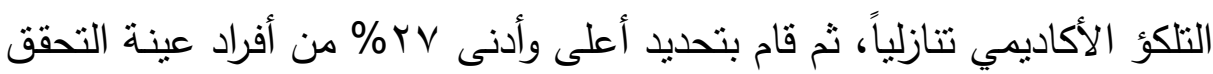

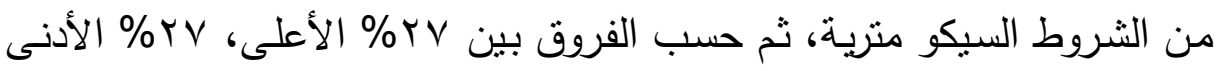
باستخدام اختبار (ت)، والنتائج يوضحها جدول (r). جدول (r) صدق المقارنة الطرفية مقياس التلكؤ الأكاديمي

\begin{tabular}{|c|c|c|c|c|c|}
\hline \multicolumn{2}{|c|}{ 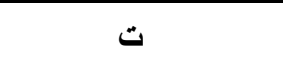 } & \multirow{2}{*}{ الانحراف } & \multirow{2}{*}{ الحسابي } & \multirow{2}{*}{ العدد } & \multirow{2}{*}{ المجموعة } \\
\hline الدلالة & 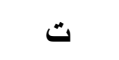 & & & & \\
\hline \multirow{2}{*}{$\ldots$} & \multirow{2}{*}{$00 .\{\wedge$} & $r . .1$ & $T \leq .1 Y$ & r. & r \% الأعلى \\
\hline & & T.TV & HIr.r. & r. & \% \% الأدنى \\
\hline
\end{tabular}

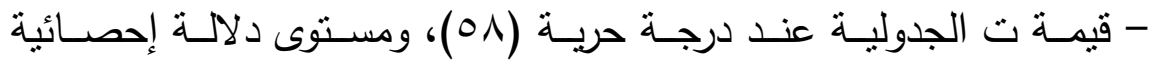

$$
1.99=(. .00)
$$

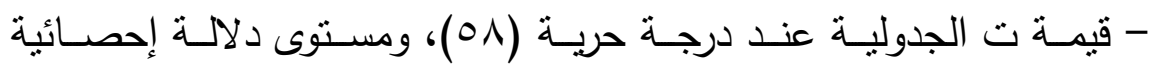

$$
\text { r. } T \varepsilon=(\cdot \cdots 1)
$$

يتضـح مـن جدول (Y) وجود فروق دالـة إحصـائياً عند مسـتوى ( ( . . ) بين

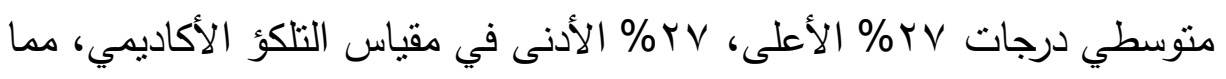

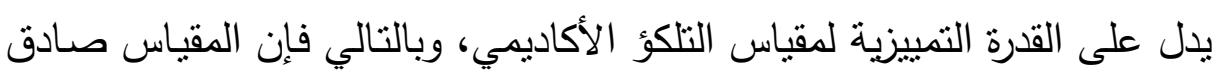
في قياس التلكؤ الأكاديمي. 


\section{ثالثًا: صدق المحك}

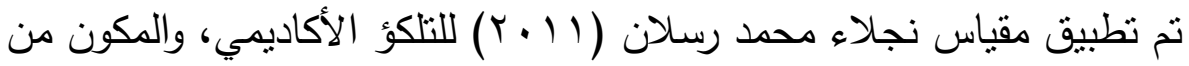

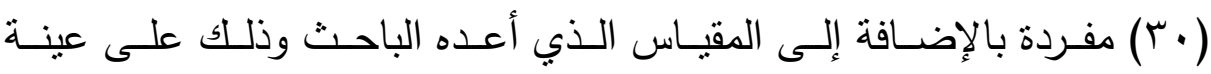

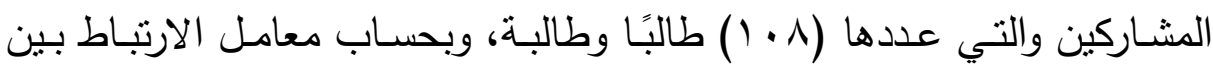

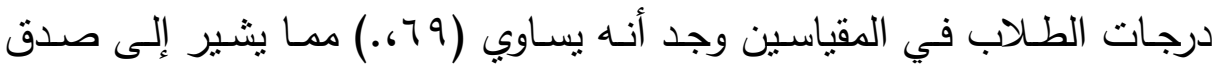
المقياس الحالي. ثبات المقياس: تم حساب ثبات مقياس التلكؤ الأكاديمي بطريقتين كما يلي: ا-بريقة ألفا كرونباخ. r-طريقة التجزئة النصفية.

\section{Cronbach's Alpha أولاً: طريقة ألفا كرونباخ}

وذلك بحساب ثبات مقياس التلكؤ الأكاديمي بعد حذف المفردة، والنتائج يوضحها

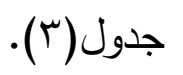

جلول(ب) معاملات ثبات مقياس التلكؤ الأكاديمي بطريقة الفاكرونباخ

\begin{tabular}{|c|c|c|c|c|c|c|c|c|c|}
\hline معامل الثبات & 5 & معامل الثبات & 5 & معامل الثبات & 5 & معامل الثبات & 5 & معامل الثبات & r \\
\hline$\because \vee \wedge$. & ro & $\because \vee \wedge$. & 19 & $\because \vee \wedge$. & $1 \pi$ & $\because \vee \vee q$ & v & $\because \vee \vee q$ & 1 \\
\hline$\because \vee \vee \wedge$ & r & $\because \vee \wedge$. & $r$. & $\because \vee \vee q$ & $1 \varepsilon$ & $\because \vee \vee q$ & $\wedge$ & $\because \vee \wedge$. & r \\
\hline$\because \vee \wedge$. & rV & $\because V \vee V$ & r) & $\because \vee \vee q$ & 10 & $\because \vee \wedge$. & 9 & $\because \vee \vee q$ & $r$ \\
\hline$\because \vee \vee T$ & rᄉ & $\because \vee \wedge$. & rr & $\because \vee \vee \varepsilon$ & 17 & $\because \vee \vee q$ & 1. & $\because \vee \vee 0$ & $\varepsilon$ \\
\hline.$\vee \wedge$. & rq &.$\vee \wedge$. & r & $\because \vee \wedge$. & IV & $\because \vee \wedge$. & 11 & $\because \vee \wedge$. & 0 \\
\hline$\therefore \vee \vee \neg$ & r. & $\because V \vee \varepsilon$ & $r \varepsilon$ & $\because \vee \vee q$ & 11 & $\because \vee \vee Y$ & Ir & $\because \vee \vee q$ & 7 \\
\hline
\end{tabular}

ومن جدول (r) يتضح أن جميع معاملات ألفا تقل عن معامل ثبات ألفا لمجموع

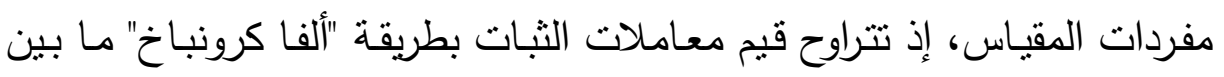

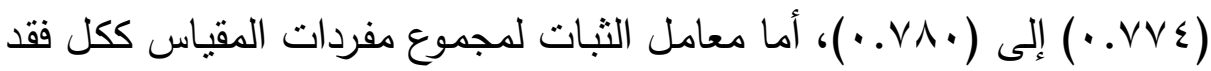




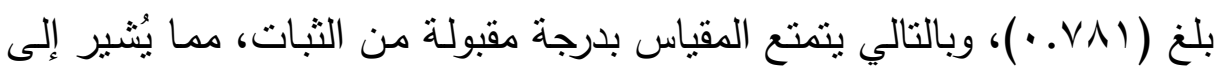
إمكانية استخدامه في البحث الحالي والتقة بالنتائج التي سيسفر عنها. ثانياً: طريقة التجزئة النصفية

قام الباحث بحساب معامل الارتباط بين المفردات ذات الأرقام الفردية والزوجية لمقياس التلكؤ الأكاديمي، ثم قام بتصحيحه بمعادلة "سبيرمان وبراون، والنتائج يوضحها جدول (ع).

جدول (ء ) معامل الارتباط ومعامل ثبات مقياس التلكؤ الأكاديمي بطريقة التجزئة النصفية ل ابنة

\begin{tabular}{|c|c|c|}
\hline معامل الثبات بعد التصحيح بمعادلة & معامل الارتباط & المتغير \\
\hline..$\wedge \curlyvee \wedge$ & $\cdot V \cdot Y$ & المفردات ذات الأرقام الفردية والزوجية \\
\hline
\end{tabular}

يتضح من جدول (乏) أن مقياس التلكؤ الأكاديمي يتمتع بدرجة مقبولة من الثبات مما يسمح باستخدامه في البحث الحالي.

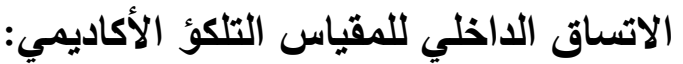

قام الباحث بحسـاب معامل الارتباط بين درجـة كل مفردة وبين الدرجـة الكلية لمقياس التلكؤ الأكاديمي، ويوضح جدول (0) نتائج معاملات الارتباط. جدول (0) معاملات الارتباط بين درجة كل مفردة ودرجة الدرجة الكلية لمقياس التلكؤ الأكاديمي

\begin{tabular}{|c|c|c|c|c|c|c|c|c|c|}
\hline الارنباط معامل & s & معامل الارتباط & s & معامل الارتباط & s & الارتباط معامل & s & معامل الارتباط & 5 \\
\hline זדצ. . & ro & $.7 V \leq$ & 19 & .011 & r & אדד.. & v & .701 & 1 \\
\hline $.7 \leq 0$ & rד & סזד. & $r$. & $.07 \pi$ & $1 \varepsilon$ & $. v 1 \leq$ & $\wedge$ & .707 & r \\
\hline. .019 & $r V$ & זדום & r) & $.0 \mathrm{NV}$ & 10 & $. v 1 \leq$ & 9 & אדצ.. & $r$ \\
\hline. .011 & rᄉ &.$\neg \wedge \vee$ & rT & סזד. & 17 &.$V Y O$ & 1. & $.7 \leq V$ & $\varepsilon$ \\
\hline. $.0 \mathrm{VV}$ & rq & $.7 \times 7$ & r & $.7 \leq V$ & iv & תז74. & 11 & .710 & 0 \\
\hline $.0 \leqslant 1$ & $r$. & דזד.. & $r \varepsilon$ & דזי.. & 11 &.$T V \varepsilon$ & Ir &.$T V V$ & 7 \\
\hline
\end{tabular}

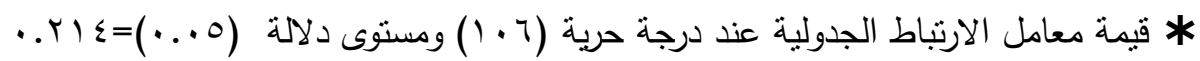

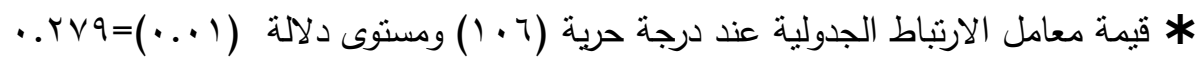


يتضح من جدول (0) أن درجة كل مفردة مرتبطة ارتباطاً موجباً مع الدرجة الكلية

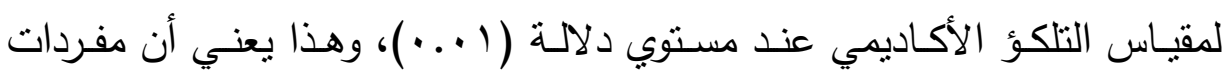
المقياس متماسكة داخلياً مع الدرجة الكلية للمقياس. إعداد الباحث (ملحق r) ثانيًا: مقياس عادات العقل

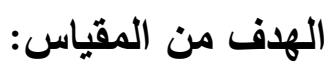

يهذف هذا المقياس إلى الكثف عن مسنوى العادات العقلية لدى طلاب كلية التربية جامعة الإسكندرية.

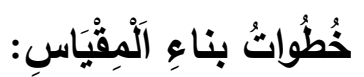

تم الاطـلاع على الأطر النظريـة العربيـة والأجنبيـة التي تتاولت عـادات العقل، منل: (Costa, A. \& Kallik, B.,2000)، (إمام مصطفى سيد، ومنتصر صلاح عمر، (1) (r)، وكذلك باقي الدراسات السابقة التي ذكرت بالبحث الحالي.

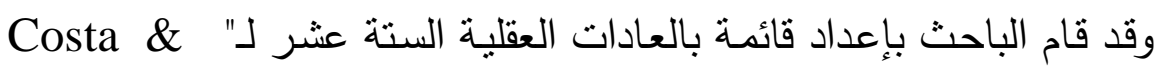

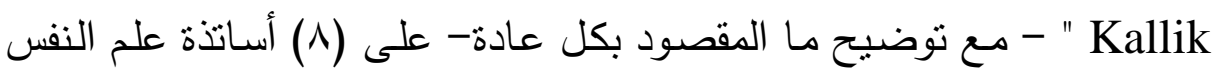

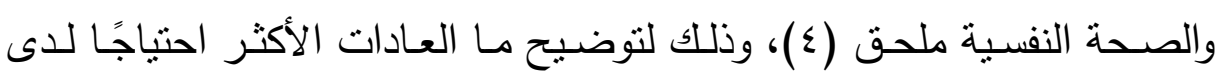
طلاب كلية التربية، وتم الاتفاق على خمس عادات صاحبة أكبر نسب اتفاق من

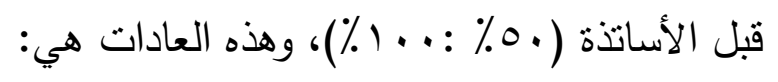

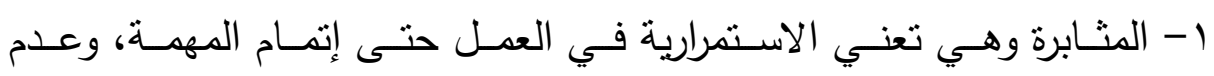
الاستسلام أمام أي عائق يعيق الوصول لإني للهدف. ץ- التفكير في التفكير وهي تعني الوعى بما نريد أن نعله، وبالاستراتيجيات المنبعة لتتفيذه الحلول، وكذلك التأمل في مدى إنتاجية تفكيرنا وتقويمه.

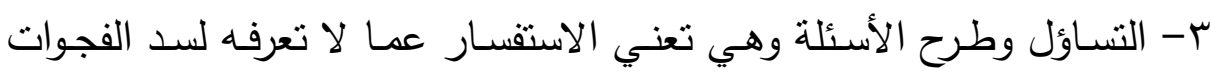

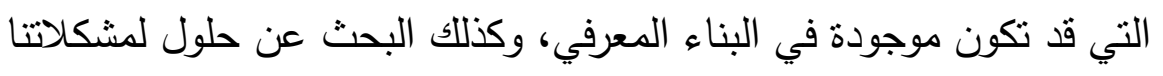
عن طريق طرح الأسئلة. ـ - التفكير التبادلي وهي تعني التفكير باتساق مـع الآخرين، والتواصل معهم الآنه والإيثار، وكذلك السعي وراء الرأي الجماعي لتحقيق الأهداف. 
ه- السعي من أجل الدقة وهي تعني الالتزام بالمراجعة وفي تتفيذ المهام، والتأكد من سلامة النتائج التي ينبغي الوصول إليها. وصف المقياس

تم صياغة ستة مفردات تقيس التعريف الإجرائي لكل عادة من عادات العقل

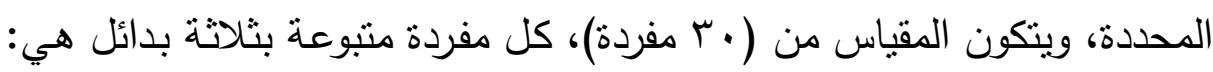

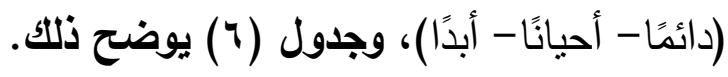

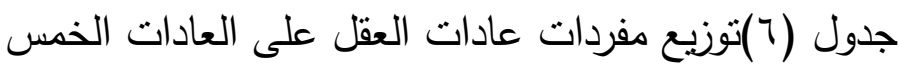

\begin{tabular}{|c|c|c|c|}
\hline العدد & المفردات & 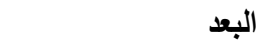 & c \\
\hline 7 & $r q-r 1-17-11-q-1$ & المثابرة & 1 \\
\hline 7 & $r V-r Y-1 V-1 Y-V-r$ & التفكير في التفكير & r \\
\hline 1 & $r \Lambda-r r-1 \Lambda-1 r-\Lambda-r$ & التساؤل وطرح الأسئلة & $r$ \\
\hline 7 & $Y q-Y \leq-1 q-1 \leq-q-\varepsilon$ & التفكير التبادلي & $\varepsilon$ \\
\hline 7 & $r \cdot-r_{0}-r_{-}-10-1 \cdot-0$ & السعي من أجل الاقة & 0 \\
\hline
\end{tabular}
طريقة تقدير درجات المقياس تم تقدير الاجابة على النحو التالي، دائمًا (ثلاتث درجات)، أحيانًا (درجتان)، أبدًا (درجة واحدة)، وبذلك تصبح الدرجة العظمى للإجابة على المقياس ( • (9)،

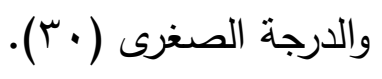
صدق المقياس: تم حساب صدق مقياس عادات العقل بثلاث طرق كالتالي: 1- صدق المحكمين. r- ب - بدق المقارنة الطرفية.

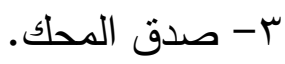

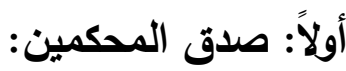
تم عرض المقياس على (^) من السادة المحكمين تخصص علم النفس التربوي

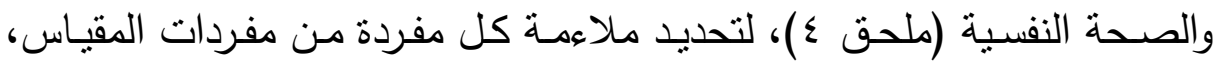


ومعرفـة مدى وضسوح المفردات وأسلوب صياغتها، حيث تراوحت نسب اتفـاق

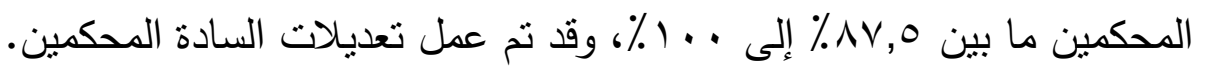

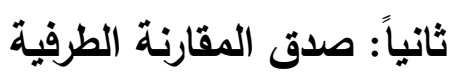
قام الباحث بترتيب الدرجات التي حصل عليها الطلاب عينة البحث في

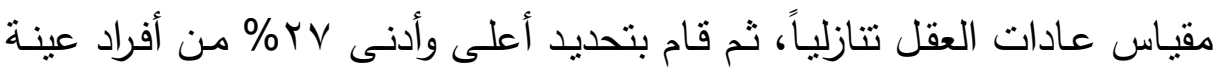

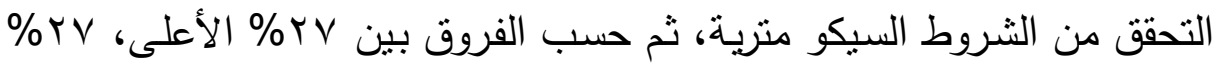
الأدنى باستخدام اختبار (ت)، والنتائج يوضحها جدول (V) (V). جدول (V) صدق المقارنة الطرفية مقياس عادات العقل

\begin{tabular}{|c|c|c|c|c|c|}
\hline \multicolumn{2}{|r|}{ ت } & \multirow{2}{*}{ المعياري } & \multirow{2}{*}{ الحسابيـ } & \multirow{2}{*}{ العدد } & \multirow{2}{*}{ المجموعة } \\
\hline الدلادة & $ت$ & & & & \\
\hline \multirow{2}{*}{$\ldots 1$} & \multirow{2}{*}{ r.7. } & r.४^ & $\varepsilon r . V r$ & $r$. & Y \% الأعلى \\
\hline & & r.vi & vv.v. & $r$. & V \% الأدنى \\
\hline
\end{tabular}

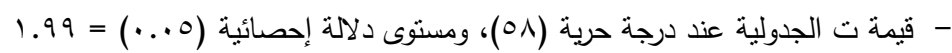

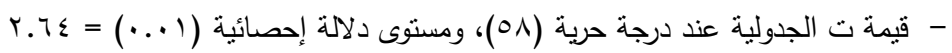

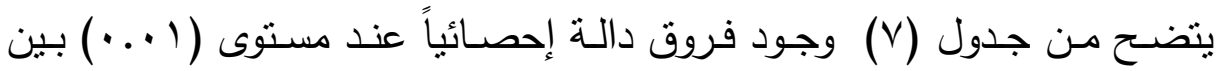

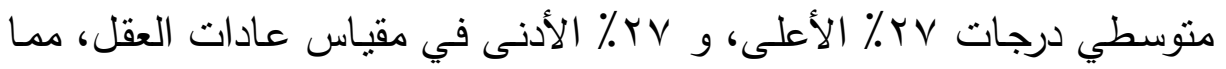

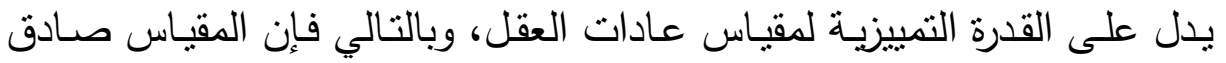
لقياس عادات العقل. ثُالثًا: صدق المحك عل عان

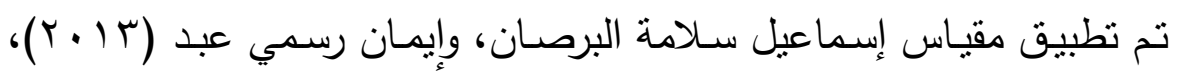

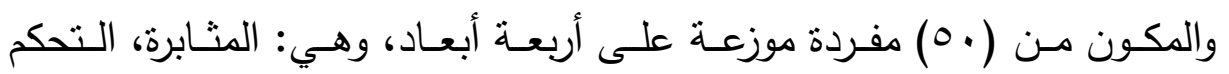

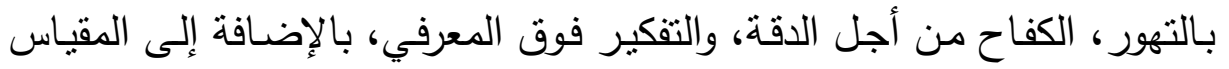
الذي أعده الباحث وذللك على عينـة المشــاركين والتـي عددها (1 + ( ) طالبًا وطالبة، وبحساب معامل الارتباط بين درجات الطلاب في المقياسين وجد أنهـ

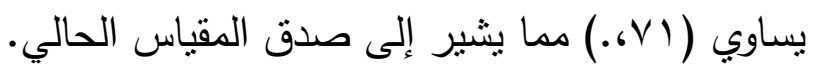

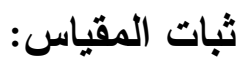


مجلة الاراسات التربوية والانسانية ـ كلية التربية ـ جامعة دمنهور . المجلد الثامن - العدد(ץ)- لسنة 1 ــץ

تم حساب ثبات مقياس عادات العقل بطريقتين:

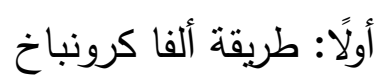

ثانيًا: طريقةكيودر ريتشارد سون.

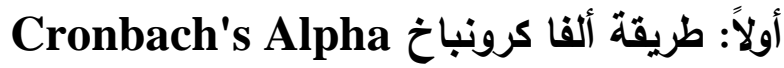

وذلك بحساب ثبات مقياس عادات العقل بعد حذف المفردة، والنتائج يوضحها

جدول (^).

جدول (^) معاملات ثبات مقياس عادات العقل بطريقة الفاكرونباخ

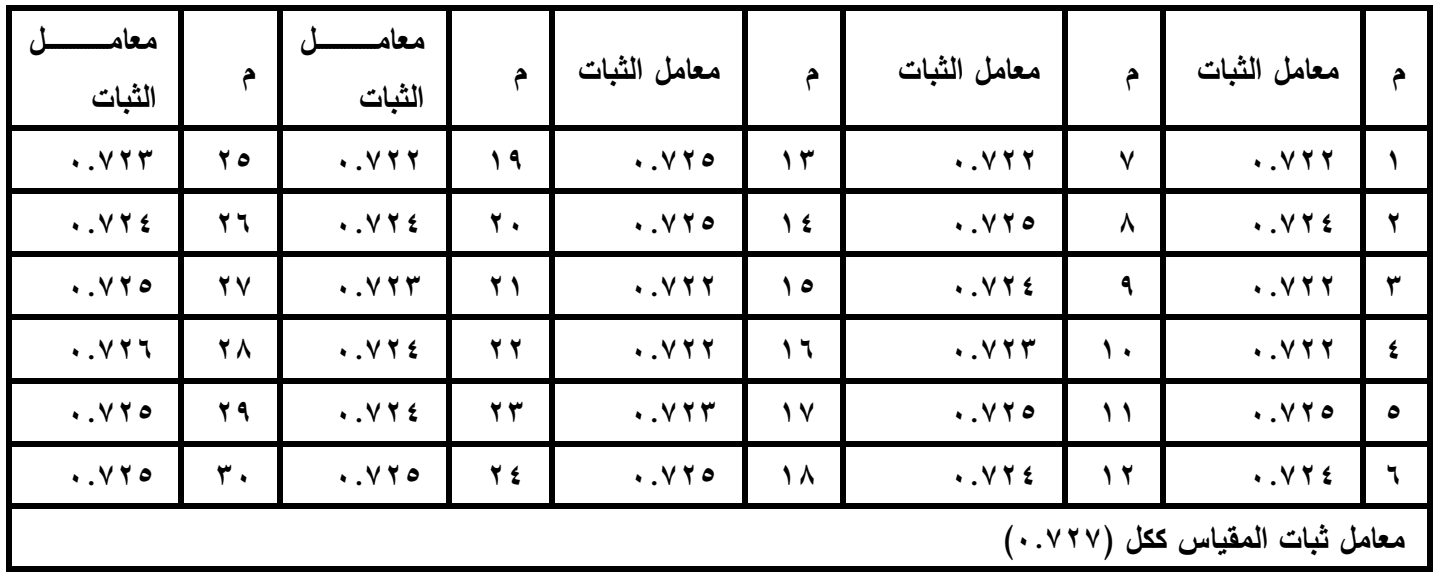

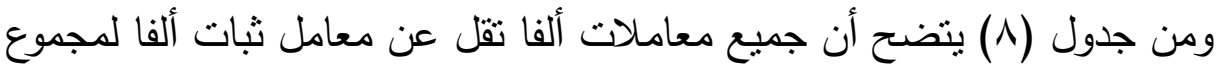
مفردات المقياس، إذ نتراوح قيم معاملات الثبات بطريقة "ألفا كرونباخ"، ما بين معاملين

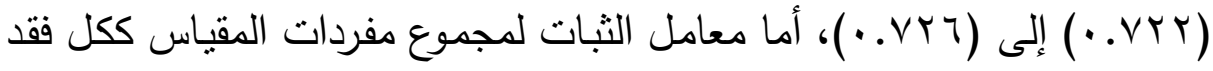

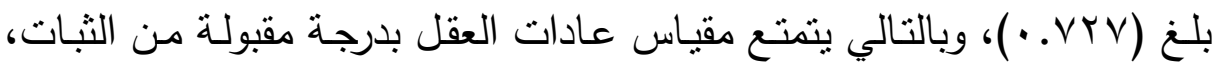
مما يُشير إلى إمكانية استخدامه في البحث الحالي، والثقة بالنتائج التي سيسفر بله عنها.

Kuder - ثانيـاً: ثبـات المقيساس باسـتخدام معادلـة كيودر - ريتثاردسـون

\section{Richardson}

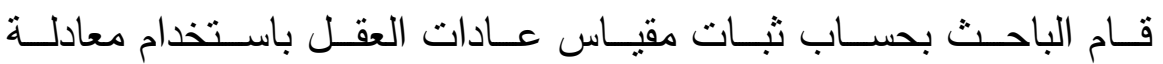
كيودرريتشاردسـون 21Kuder Richardson فكـان ثبـات المقيـاس كکـل

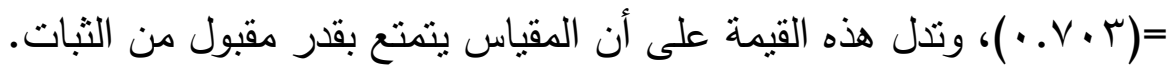


الاتساق الاخلي لمقياس عادات العقل:

الاتساق الداخلي لمفردات مقياس عادات العقل:

قام الباحث بحساب معامل الارتباط بين درجة كل مفردة ودرجة كل عادة من عن مادرد

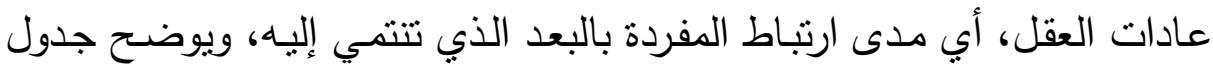
(9) (9) نتائج معاملات الارتباط.

جدول (9) معاملات الارتباط بين درجة كل مفردة ودرجة عادة عادات العقل

\begin{tabular}{|c|c|c|c|c|c|c|c|c|c|}
\hline مع عامـل الارتبـاط & r & 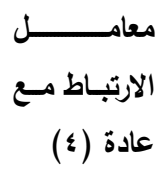 & م & مع عامـل الارتبـاط & p & مع عامـل الارتبـاط & ? & مع ععامـل الارتبـاط & م \\
\hline ס צr. & ro & .700 & 19 & $\cdot v 11$ & ir & סז7. . & $v$ & $.0 \leq 1$ & 1 \\
\hline . . & Y & $\cdots v \cdot 1$ & $r$. & $.7 \wedge 9$ & $1 \varepsilon$ & . . & $\wedge$ & O . & $r$ \\
\hline זים & rV & .790 & YI & צד & 10 & $. T \leq r$ & 9 & סזr. & $r$ \\
\hline$. \Delta V \leqslant$ & rA & .099 & rr & rra & 17 & ז7ד.. & 1. & r & $\varepsilon$ \\
\hline $.0 \leq 1$ & rq & $.4 \wedge 9$ & r & $.70 r$ & IV & . . TYY & 11 & .100 & 0 \\
\hline \&.OT & r. & otro & $r \varepsilon$ &. $.09 \wedge$ & 11 & גזד. & Ir & צזT. & 1 \\
\hline
\end{tabular}

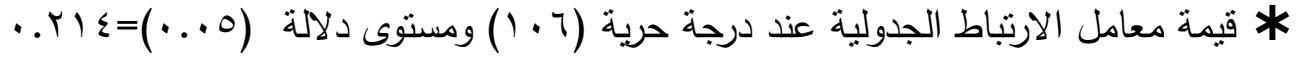

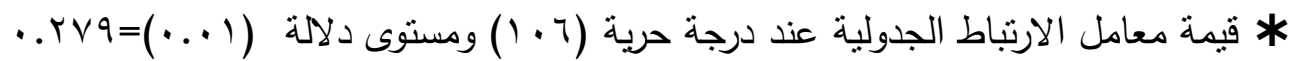
كما قام الباحث بحساب معامل الارتباط بين درجة كل مفردة وبين الدرجة الكلية لمقياس عادات العقل، ويوضح جدول (• ( ) نتائج معاملات الارتباط. 
مجلة الاراسات التربوية والانسانية ـ كلية التربية ـ جامعة دمنهور . المجلد الثامن - العدد(ץ)- لسنة 1 ــץ

جدول ( • 1 ) معاملات الارتباط بين درجة كل مفردة ودرجة الدرجة الكلية

لمقياس عادات العقل

\begin{tabular}{|c|c|c|c|c|c|c|c|c|c|}
\hline معامل الارتباط مع & م & الارتباط مع معامل & م & معامل الارتباط الدرجة & م & معامل الارتباط & م & معامل الارتباط مع الدرجة الكلية & p \\
\hline . & ro & $.7 \leq 7$ & 19 &. $.79 \mathrm{~V}$ & ir &. .719 & $v$ & rorr & 1 \\
\hline ITI & rq & .7199 & $r$. & . TVo & $1 \varepsilon$ & בזד & $\wedge$ & . & $r$ \\
\hline roor & $r v$ &. .411 & $r$ & . & 10 & $.7 r v$ & 9 &. .711 & $r$ \\
\hline זד. & rA & .011 & rr & צוצו. & 17 & $.7 \leqslant 1$ & 1. & $\cdot . r \cdot r$ & $\varepsilon$ \\
\hline $.0 \leqslant 1$ & rq & $.7 \times 9$ & r & $.7 \leqslant 1$ & iv & .711 & 11 & סזום. & 0 \\
\hline $.7 r 1$ & $r$. & $.71 \mathrm{~V}$ & $r \varepsilon$ & $.0 \mathrm{~V} \wedge$ & 11 & צY74. & Ir & D . & 7 \\
\hline
\end{tabular}

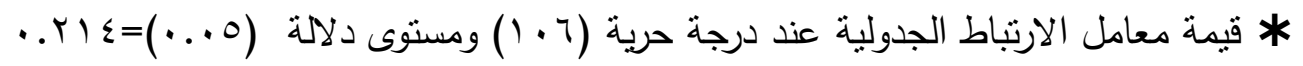

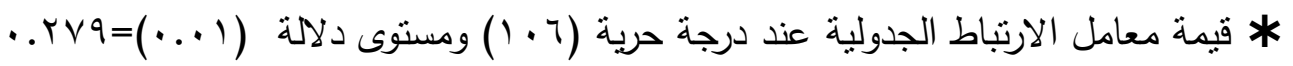

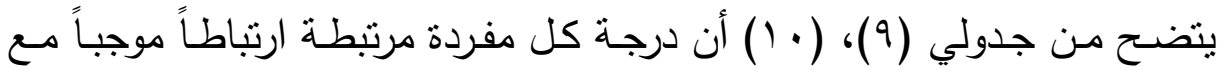

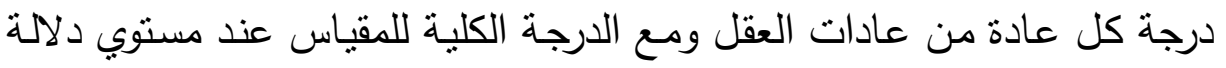

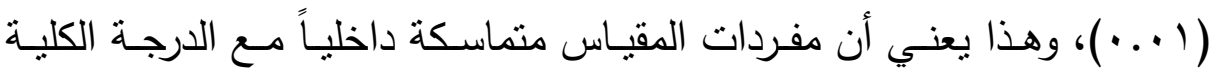

للمقياس.

الاتساق الاخلي لأبعاد المقياس:

للتحقق من اتسـاق محتوى المقياس ككل وارتبـاط أبعاده بعضـها ببعض لابعاد قام

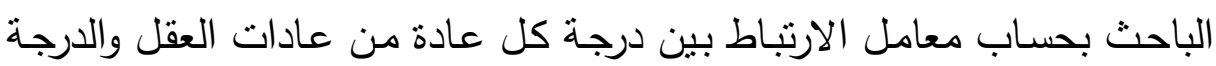

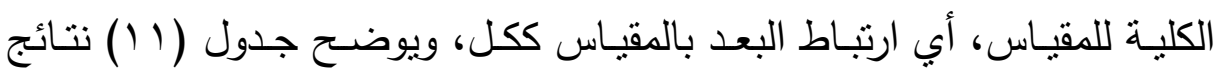

معاملات الارتباط.

جدول (1 1) معاملات الارتباط بين درجة كل عادة من عادات العقل والدرجة

الكلية لمقياس عادات العقل

\begin{tabular}{|c|c|c|c|c|c|}
\hline 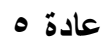 & عادة ع & عادة ب & 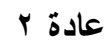 & عادة ا & 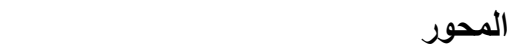 \\
\hline $.0 \wedge 7$ & $.7 \leq 9$ & $.7 \leqslant 0$ & $.7 r \wedge$ & r. & معامل الارتباط مع الدرجة الكلية للمقياس \\
\hline
\end{tabular}

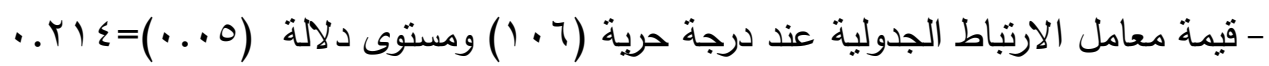




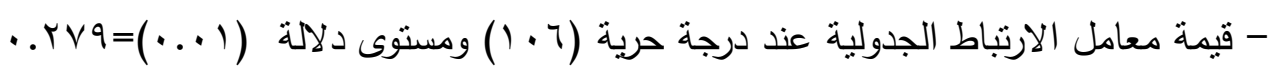

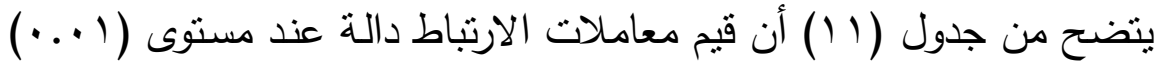
مما يدل على قوة الاتساق الداخلي لكل عادة من عادات العقل والدرجة الكلية للمقياس. إعداد الباحث (ملحق r) مقياس الأفكار التلاعقلانية

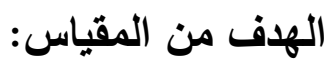
يهدف هذا المقياس إلى الكثف عن مستوى الأفكار اللاعقلانية لدى طلاب كلية التربية جامعة الإسكندرية.

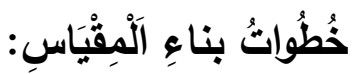
تم الاطـلاع على الأطر النظريـة العربيـة والأجنبيـة التي تتاولت الأفكار

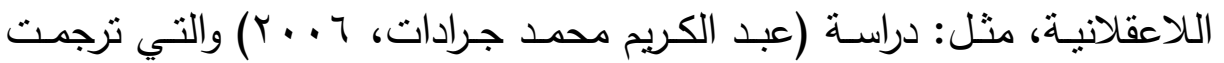
مقياس Klages للأفكار اللاعقلانية، ودراسة (سعيد عبد الرحمن محمد، وحمادة علي عبد المعطي، ( • r)، وكذلك باقي الدراسات السابقة التي ذكرت بالبحث الحالي.

وقد قام الباحث بإعداد قائمـة بالأفكار اللاعقلانيـة الأربعـة عشر (طلب الاستحسان-الكمال الثخصي -اللوم للذات وللأخرين-توقع الكوارث-الاعتمادية-

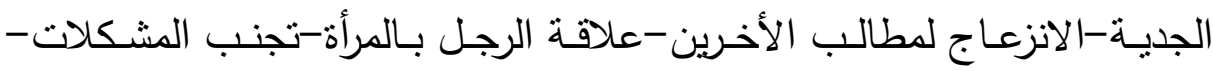

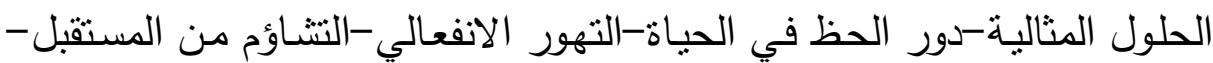
طلب الحصول على حب الأخرين بالتكافؤ) -وتوضيح ما المقصود بكل فكرة-

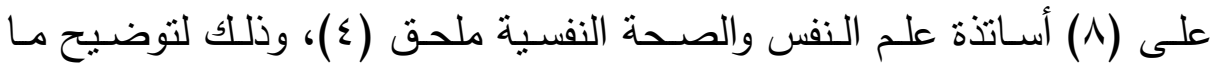

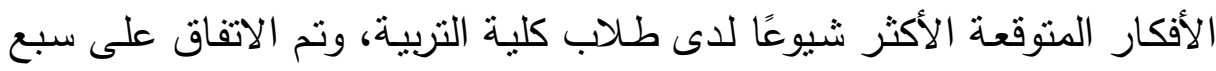
أفكار صاحبة أكبر نسب اتفاق من قبل الأساتذة( •0\% : . . . (\%)، وهذه الأفكار

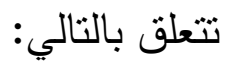
1- طلب الاستحسـان وتتمثنل في السـعي لتحقيـق رضـاء الآخرين حتى ولـو تعارض هذا مع أهدف الفرد نفسه. 
ץ- الاعتمادية وتتمتل في الاعتماد الكامل للفرد على الآخرين، وأن يكون تابعًا

\section{لهم.}

r- الجديـة وتتمثل في ميل الفرد للرسمية وفي تعاملاته، وأن المرح يقلل من

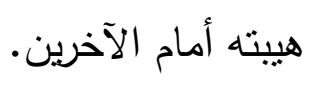

ع - علاقة الرجل بالمرأة وتتمثل في الإيمان بعدم المساواة وأن الرجل أفضل من

$$
\text { المرأة، والتحيز للرجل على حساب المرأة. }
$$

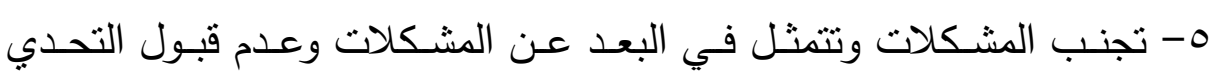
والإيمان بأن الحياة السهلة تخلو من الصعوبات.

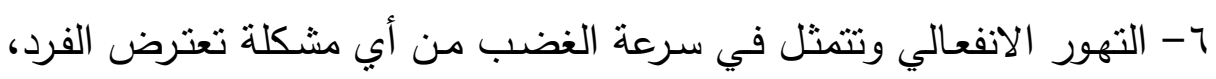

$$
\text { حتى ولو لم تنتحق هذا. }
$$

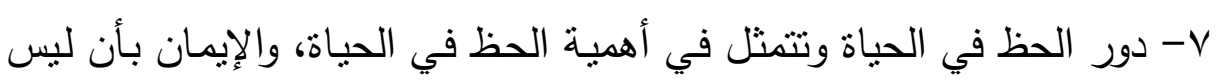
بإمكان الفرد تغيير أي شيء بنفسه، وأن سعادته ليست بيده.

\section{وصف المقياس بإن}

تم صـياغة سـتة مفـردات تقيس التعريـف الإجرائي لكل فكـرة مـن الأفكـار اللاعقلانية المحددة، ويتكون المقياس من (ץ؟ مفردة)، كل مفردة متبوعة بثلاثة

\begin{tabular}{|c|c|c|c|}
\hline 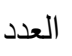 & 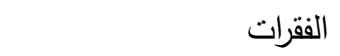 & 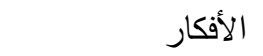 & م \\
\hline 7 & $r\urcorner-r q-r r-10-\Lambda-1$ & طلب الاستحسان & 1 \\
\hline 7 & $r V-r \cdot-r r-17-9-r$ & الاعتمادية & r \\
\hline 7 & $r \wedge-r \mid-r \varepsilon-1 V-1 \cdot r$ & الجدية & r \\
\hline 7 & $r q-r r-r 0-11-11-\varepsilon$ & علاقة الرجل بالمرأة & $\varepsilon$ \\
\hline 7 & $\varepsilon \cdot-r r-r q-19-1 r-0$ & تجنب المشكلات & 0 \\
\hline 7 & $\varepsilon 1-r \varepsilon-r V-r \cdot-1 r-7$ & التهور الانفعالي & 7 \\
\hline 7 & $\varepsilon r-r 0-r \wedge-r 1-1 \leqslant-r$ & دور الحظ في الحياة & V \\
\hline
\end{tabular}

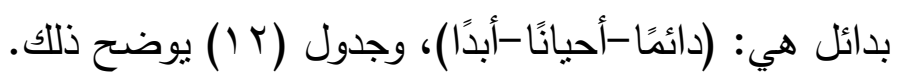

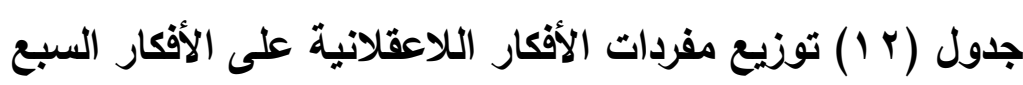

طريقة تقدير درجات المقياس 
تم تقدير الاجابة على النحو التالي، دائيًا (تلاث درجات)، أحيانًا (درجتان)، أنان

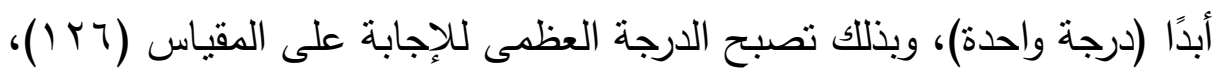

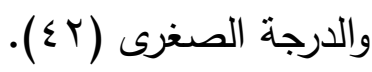
صدق المقياس: تم حساب صدق مقياس الأفكار اللاعقلانية بطريقتين كالتالي:

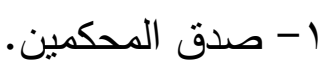
r - بدق المقارنة الطرفية.

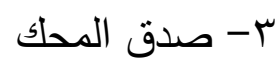

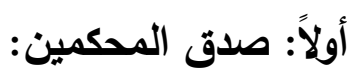
تم عرض المقياس على (^) من السادة المحكين تخصص علم علم النفس التربوي

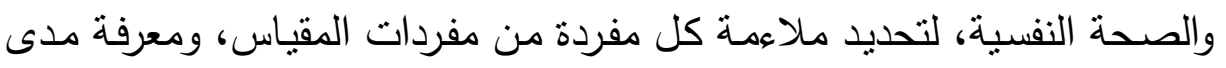

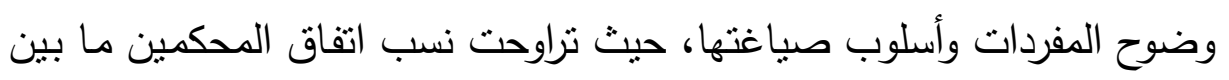
\% \% \%,0 ثانياً: صدق المقارنة الطرفية:

قام الباحث بترتيب الدرجات التي حصل عليها الطلاب عينة البحث في مقياس

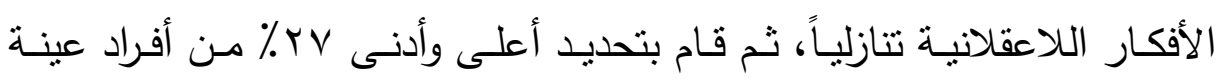

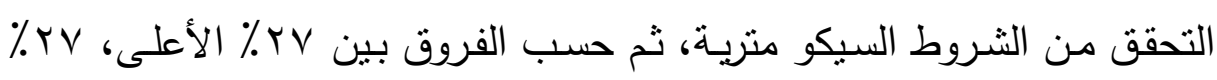

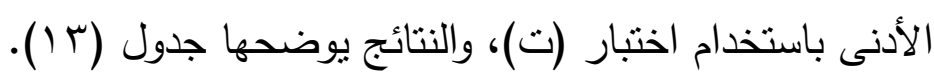

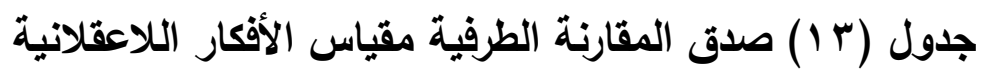

\begin{tabular}{|c|c|c|c|c|c|}
\hline & $ت$ & الاتــــــــراف & المتوســــــــ & العدد & المجموعة \\
\hline الالالة & ت & المعياري & الحسابي & المغد & المجبوس \\
\hline \multirow{2}{*}{$\because \cdot 1$} & \multirow{2}{*}{$0 \cdot . r \leq$} & $P . \wedge q$ & $\Delta V . \wedge r$ & $r$. & Y \% الأعلى \\
\hline & & 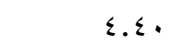 & 111.2 . & $r$. & \% rv rv \\
\hline
\end{tabular}

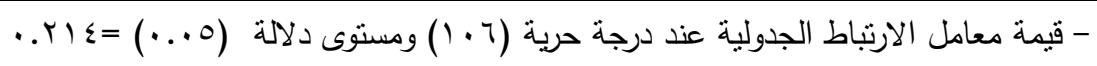

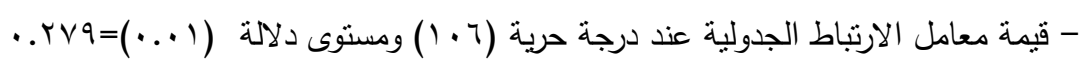


يتضح من جدول (r I I) وجود فروق دالة إحصـائياً عند مستوى (1 ...) بين

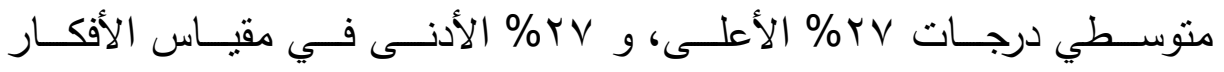
اللاعقلانية، مما يدل على القدرة التمييزية لمقياس الأفكار اللاعقلانية، وبالتالي فإن المقياس صادق لقياس الأفكار اللاعقلانية. ثالثًا: صدق المحك تم تطبيـق مقياس Klages للأفكار اللاعقلانيـة والذي ترجمـه عبد الكريم

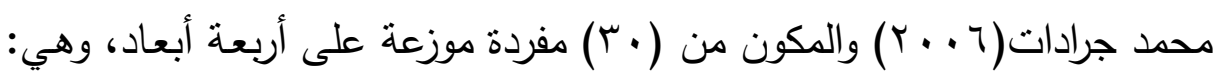

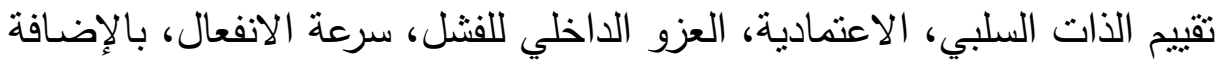
إلى المقياس الذي أعده الباحث وذللك على عينة المشاركين والتي عددها (1 • ( )

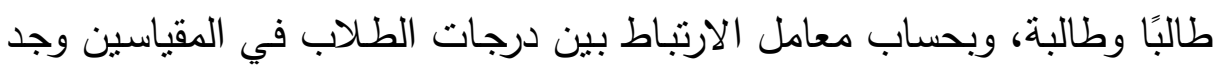
أنه يساوي (TV،.، ) مما يشير إلى صدق المقياس الحالي.

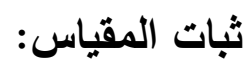
تم حساب ثبات مقياس الأفكار اللاعقلانية بطريقتين: أولاً: ألفا كرونباخ تباب تبات ثانيًا: كيودر ريبتشارد سون.

Cronbach's Alpha أولاً: ثبات المقياس بطريقة ألفا كرونباخ

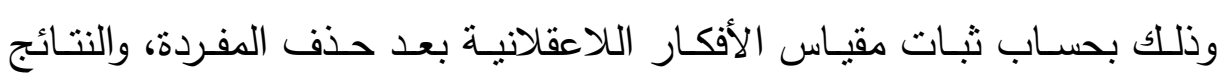
يوضحها جدول (ع ()).

جدول (ء ا ) معاملات ثبات مقياس الأفكار اللاعقلانية بطريقة الفاكرونباخ

\begin{tabular}{|c|c|c|c|c|c|c|c|c|c|}
\hline معامـل & r & الثعاتـــــــلـل & e & معامــــــل & r & معامــــــل & م & معامل الثبات & r \\
\hline $\begin{array}{r}\because V \varepsilon \\
7\end{array}$ & $r v$ & $\because v r \Lambda$ & rA & $\because V Y Y$ & 19 & $\because v \leq 1$ & 1. & $\because V \leq \leq$ & 1 \\
\hline $\begin{array}{r}\cdot v 1 \\
q\end{array}$ & $r \Lambda$ & $\because v \leq r$ & rq & $\because \vee r q$ & $r$. & $\because v \leqslant 0$ & 11 & $\cdot V r \leq$ & r \\
\hline $\begin{array}{r}\because V Y \\
1\end{array}$ & $r 9$ & $\because v \leq q$ & r. & . VRr & ri & .vrq & Ir & •VTr & $r$ \\
\hline $\begin{array}{r}\because V Y \\
\varepsilon\end{array}$ & $\varepsilon$. & $\because v \leqslant V$ & r & $\because V Y V$ & Yr & $\because$ VR & $1 \pi$ &.$v r q$ & $\varepsilon$ \\
\hline$\because V Y$ & \&1 & $\cdot V \leqslant r$ & rr & $\because V \curlyvee \wedge$ & $r r$ & $\because$ Vro & $1 \varepsilon$ & $\because V \leqslant 1$ & 0 \\
\hline
\end{tabular}




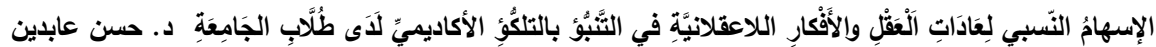

\begin{tabular}{|c|c|c|c|c|c|c|c|c|c|}
\hline r & & & & & & & & & \\
\hline${ }_{0}^{V Y}$ & $\leqslant r$ & 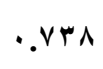 & Tr & $\because \vee \vee q$ & $Y \varepsilon$ & . & 10 & $\cdot v r q$ & 7 \\
\hline & & $\therefore V \leqslant Y$ & $r \varepsilon$ & - VYY & ro & $\because V \leqslant 0$ & 17 & $\cdot . \mathrm{V} / \mathrm{N}$ & V \\
\hline & & $\because V \leqslant r$ & ro & $\therefore v \leqslant q$ & Y & $\therefore V \leqslant 1$ & IV & $\cdot V Y Y$ & $\Lambda$ \\
\hline & & $\cdot V \leqslant 1$ & $r q$ & 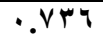 & YV & $\therefore$ V R & 11 & $\therefore V \mu V$ & 9 \\
\hline
\end{tabular}

ومـن جدول (ع () يتضـح أن جميـع معـاملات ألفـا في حالـة حذف مفردات المقياس يقل عن معامـل ثبات ألفا ل لمجموع مفردات المقيـاس، إذ تتراوح قيم

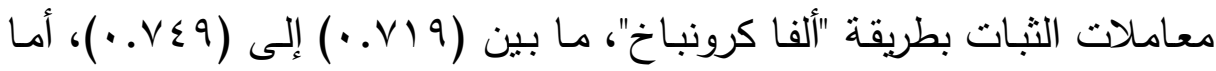

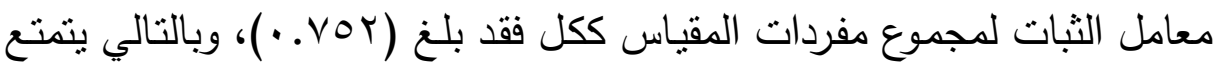
المقياس بدرجة مقبولة من الثبات، مما يُشير إلى إمكانية استخدامه في البحث الحالي والثقة بالنتائج التي سيسفر عنها.

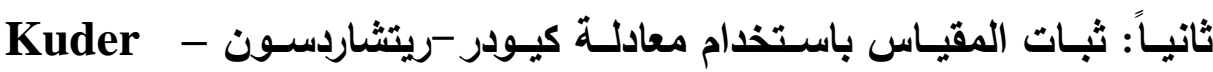

Richardson

قـام الباحـث بحسـاب ثبـات مقبـاس الأفكـار اللاعقلانيـة باسـتخدام معادلـة

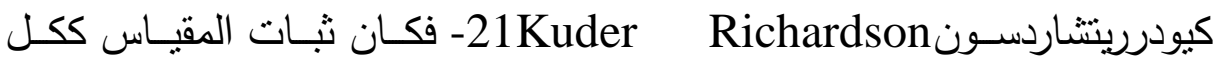

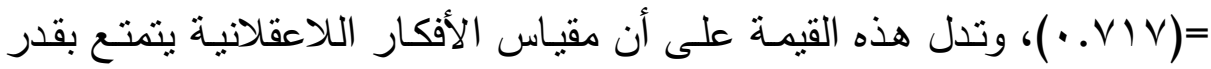
مقبول من الثبات. الاتساق الاخلي لمقياس الأفكار اللاعقلانية: الاتساق الاخلي لمفردات مقياس الأفكار اللاعقلانية:

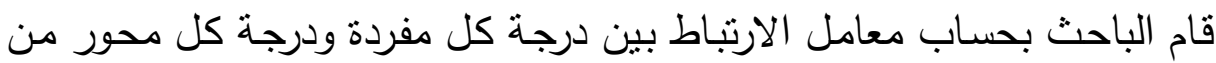

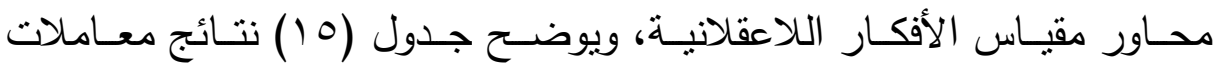
الارتباط. جدول (0 1 ) معاملات الارتباط بين درجة كل مفردة ودرجة كل محور من محاور مقياس الأفكار اللاعقلانية

\begin{tabular}{|c|c|c|c|c|c|c|c|}
\hline فكرة الارتبــاط مــع & r & فكرة الارتبــاط مــع & p & فكرة الارتبــاط مــع & p & فكرة الارتباط مـع & م \\
\hline$\because V I V$ & 19 & $\cdot .7 \leqslant V$ & $1 \pi$ & $\because .819$ & V &. .799 & 1 \\
\hline VVYI & $r$. & GVYY & $1 \varepsilon$ & GVYY & $\Lambda$ &. .701 & $r$ \\
\hline
\end{tabular}


مجلة الاراسات التريوية والانسانية ـ كلية التربية ـ جامعة دمنهور . المجلد الثامن - العدد(ץ)- لسنة ؟ 1 ـ ب

\begin{tabular}{|c|c|c|c|c|c|c|c|}
\hline$\because .19$ & YI & $\because \vee \backslash \wedge$ & 10 & $\therefore \times 10$ & 9 & -VIY & $r$ \\
\hline$\because v 10$ & YY & $\cdot . V \cdot r$ & 17 & $\cdot v \cdot 4$ & 1. & $\therefore$. VNT & $\varepsilon$ \\
\hline .791 & $r r$ & .701 & IV & 9787 & 11 & ¿VTY & 0 \\
\hline . & $Y \xi$ & $.7 \leqslant 9$ & 11 & $\because$. 180 & Ir & $\cdot .119$ & 7 \\
\hline & & فكرة الارتبـاط مــع & م & فكرة الارتبــــــــ & م & فـرة الارتبـاط مـع & p \\
\hline & & $\cdot .70 Y$ & $r v$ & .707 & $r 1$ & $\cdot T \leqslant \mu$ & ro \\
\hline & & .707 & $r \Lambda$ & .904 & $r r$ & $\because .7 \leqslant \Lambda$ & Yq \\
\hline & & $97 \leqslant 7$ & $r q$ & $\because V Y V$ & $r \mu$ & 9 & $\overline{r V}$ \\
\hline & & . IYI & $\varepsilon$. & V.VYY & r & 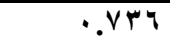 & $r \wedge$ \\
\hline & &. .710 & $\leqslant 1$ &.$V 1 r$ & ro & $\therefore \vee V \vee q$ & rq \\
\hline & & .9 .1 & $\leqslant Y$ &. $.0 Y \Lambda$ & 4 & •.VYV & $r$. \\
\hline
\end{tabular}

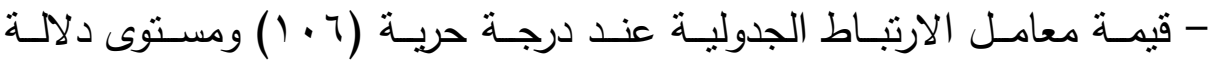

$$
. r) \varepsilon=(\cdot .00)
$$

- قيمـة معامـل الارتبـاط الجدوليـة عنـد درجـة حربـة (T ـ ( ) ومسـتوى دلالــة

$$
. r \vee q=(\cdot .1)
$$

يتضـح مـن جدول (0 1) أن درجة كل مفردة مرتبطـة ارتباطناً موجباً مـع

درجـة كل محسور مـن محساور مقيـاس الأفكـار اللاعقلانيـة عند مسـتوي دلالـة

(1 ( . •)، وهذا يعنـي أن مفـردات المقيـاس متماسـكة داخليـاً مـع الدرجـة الكليـة

للمقياس.

كما قام الباحث بحساب معامل الارتباط بين درجة كل مفردة والدرجة الكلية لمقياس الأفكار اللاعقلانية لنفس درجات عينة التحقق من الشروط السيكو متربـة وقوامها (1 • 1) طالب وطالبة، ويوضح جدول (7 ( ) نتائج معاملات الارنباط. جدول (7 1) معاملات الارتباط بين درجة كل مفردة والدرجة الكلية لمقباس

\begin{tabular}{|c|c|c|c|c|c|c|c|}
\hline مـ للكع الدرجـة الارتبـاط & e & 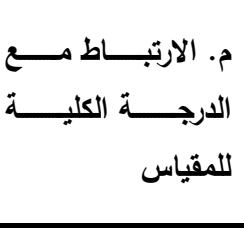 & r & مالكلية للمقياس الارتباط مـع الدرجـة & p & 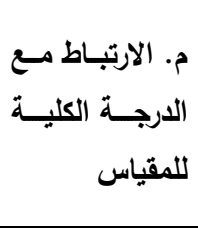 & p \\
\hline.$v 11$ & 19 & אזד. & ir & . VIr & v & . & 1 \\
\hline rVIr & $r$. & $\because V / r$ & $1 \leqslant$ & $. V 1 \leqslant$ & $\wedge$ & $. T \leqslant r$ & r \\
\hline
\end{tabular}

الأفكار التلاعقلانية 


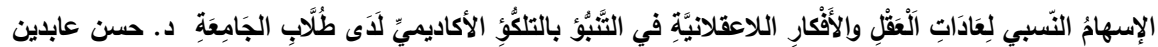

\begin{tabular}{|c|c|c|c|c|c|c|c|}
\hline . $v 11$ & YI & $\cdot v \cdot \varepsilon$ & 10 & $\cdot v \cdot q$ & 9 & . vor & $r$ \\
\hline$\therefore v .9$ & rT & $.71 \wedge 9$ & 17 & .790 & 1. &.$V Y V$ & $\varepsilon$ \\
\hline .791 & Tr & $.7 \leq 9$ & IV & .701 & 11 & .019 & 0 \\
\hline \multirow[t]{8}{*}{.$\neg \wedge \varepsilon$} & $r \varepsilon$ & צ & 11 & צ צד. & ir & .211 & 7 \\
\hline & & 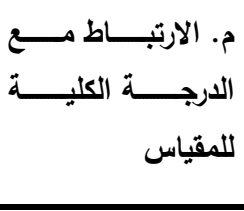 & p & الكلية للمقياس مـع الارجـة & 5 & 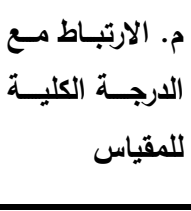 & r \\
\hline & & $. T \leqslant V$ & rv & $. \quad r \leqslant r$ & $\mu_{1}$ & . & ro \\
\hline & & 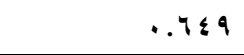 & $r \wedge$ & $.7 \leq 1$ & rr & צזד. & Y \\
\hline & & - & rq & rvir & rr & $.7 r V$ & rV \\
\hline & & r & $\varepsilon$. &.$v 11$ & ז & IVYY & $r \wedge$ \\
\hline & & .7 .9 & \& & $\cdot v \cdot 1$ & ro & .VYI & rq \\
\hline & & .7 .1 & $\leq r$ & $.0 r q$ & 4 & $\cdots \vee 19$ & $r$. \\
\hline
\end{tabular}

- قيمـة معامـل الارتبـاط الجدوليـة عنـد درجـة حربـة (T ـ ( ) ومسـتوى دلالــة

$$
\cdot r) \varepsilon=(\cdot .0)
$$

- قيمـة معامـل الارتبـاط الجدوليـة عنـد درجـة حربـة (7 · ( ) ومسـتوى دلالــة

$$
\because r \vee q=(\cdot .1)
$$

يتضـح مـن جدول (7 ( ) أن درجـة كـل مفـردة مرتبطـة ارتباطـاً موجبـاً مـع

والدرجـة الكليـة لمقيـاس الأفكار اللاعقلانيـة عند مسـتوي دلالـة ( ( ...)، وهذا يعني أن مفردات المقياس متماسكة داخلياً مـع الدرجة الكليـة للمقياس، ممـا يدل على الاتساق الداخلي لمفردات المقياس. الاتساق الأخلي لأبعاد المقياس:

للتحقق مـن اتسـاق محتوى المقيـاس ككل وارتبـاط أبعـاده بعضـها بـبعض قـام الباحث بحسـاب معامل الارتباط بين درجة كل محور والدرجة الكلية للمقياس، ويوضح جدول (IV) نتائج معاملات الارتباط. 
مجلة الاراسات التربوية والانسانية ـ كلية التربية ـ جامعة دمنهور . المجلد الثامن - العدد(ץ)- لسنة 1 ــץ

جدول (V V ) معاملات الارتباط بين درجة كل محور والدرجة الكلية لمقياس

الأفكار اللاعقلانية

\begin{tabular}{|c|c|c|c|c|c|c|c|}
\hline فكرة V & فكرة 1 & فكرة ه & فكرة ؛ & فكرة r & فكرة ץ & فكرة 1 & محاور المقياس \\
\hline דצוד. & . & $.7 \mathrm{VV}$ & $\therefore v \cdot \varepsilon$ & . . TV & . .794 &.$v \cdot 7$ & معامل الارتباط \\
\hline
\end{tabular}

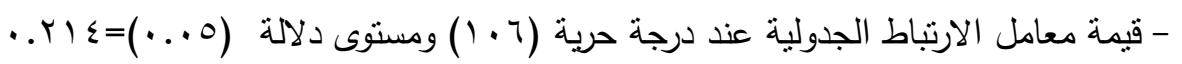

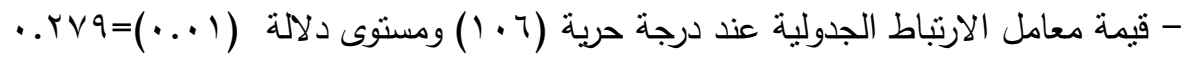

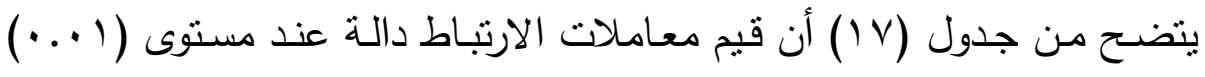
مما بدل على قوة الاتساق الداخلي لكل محور والدرجة الكلية للمقياس ككل.

\section{نتائج البحث ومناقشتها}

\section{نتائج الفرض الأول ومناقشته}

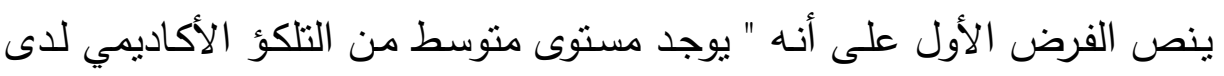
طلاب كلية التربية جامعة - جامعة الإسكندرية ". وللتحقق من صحة هذا الفرض قام الباحث بحساب المتوسط الحسابي والانحراف الإنديه المعياري والنسبة المئوية للمتوسط، حيث اعتمد الباحث على المتوسط الحسابي كمحك لتحديد مستوى التلكؤ الأكاديمي لطلاب كلية التربية-جامعة الإسكندرية، حدد الباحث مستوى الموافقة لعينة البحث على مقياس ليكرت الخماسي، طبقا للمعادلة الآتية:

مدى الاستجابة = لــ

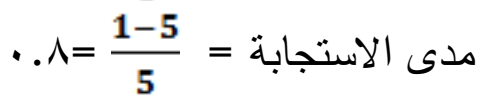

وقد تم أضافة هذه القيمة (^, · ) إلى أقل قيمة في المقياس وهي الواحد الصحيح؛

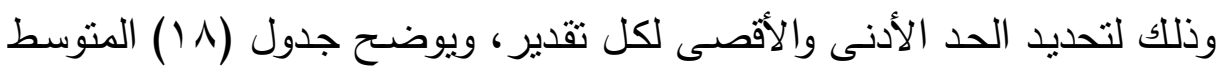
ونسبته المئوية ودرجة التقدير المقابلة له. 


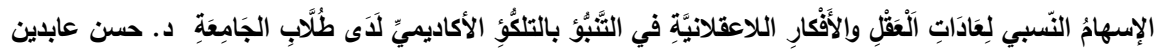

جلول (1) المتوسط ونسبته المئوية ودرجة التقاير المقابلة له

\begin{tabular}{|c|c|c|}
\hline درجة التقدير المقابلة له & النسبة المئوية للمتوسط & المتوسط الحسابي \\
\hline منخفضة جداً & 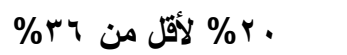 & ا لأقل من 1.1 \\
\hline منخفضة & צr\% لأقل من r\% & 1. الأكل من 7. \\
\hline متوسطة & 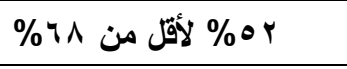 & 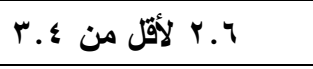 \\
\hline عالية & 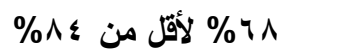 & ع.ب لأقل من Y. \\
\hline عالية جداً & $\% 1 \ldots-\% \wedge \leq$ & $0-\varepsilon . r$ \\
\hline
\end{tabular}

يوضح جدول (1) المتوسط ونسبته المئوية ودرجة التقدير المقابلة له. كمـا قام الباحث بحسـاب المتوسط الحسـابي والانحراف المعيـاري والنسـبة

المئوية للمتوسط، والنتائج يوضحها جدول (9 (1).

جدول (9 9 ) المتوسط ونسبته المئوية ودرجة التقدير المقابلة له هله

\begin{tabular}{|c|c|c|c|}
\hline اللمبتة المئوية & الانحراف المعياري & المتوسط الحسابي & المتغير \\
\hline \%rr.\& & $1 . . r$ & r.lr & التلكؤ الأكاديمي \\
\hline
\end{tabular}

ملاحظة أكبر درجة في مقياس ليكرت الخماسي=(0)

يتضح من جدول (9 1) أن قيمة المتوسط الحسابي لعينة البحث في مقياس

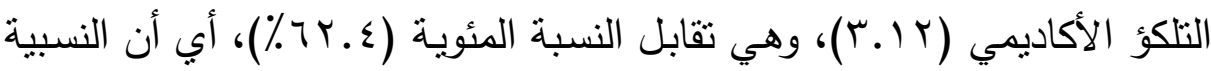

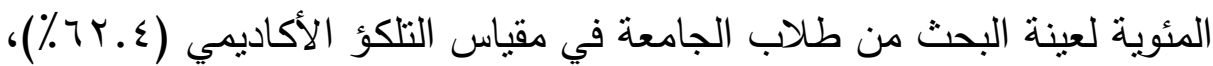
وهذه النسبة طبقًا للمحكات الموضحة بجدول (1) منوسطة.

وتتفق هذه النتيجة مع النتائج التي توصلت إليها دراسة (Balkis,M.,2013)،

(ALQuadah,M.,et al.,2014) من التلكؤ الأكاديمي لدى طلاب الجامعة، كما أثنارت دراسات أن النسبة الأكبر

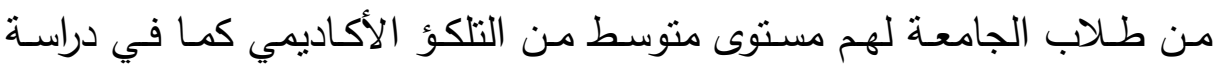

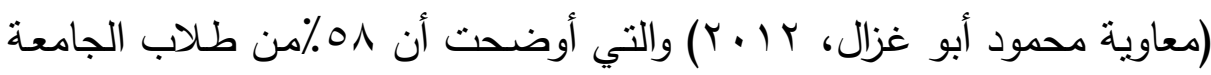

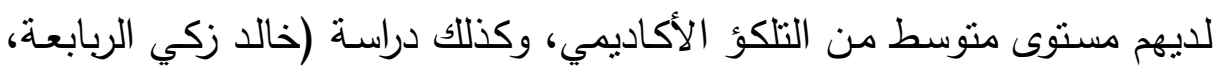




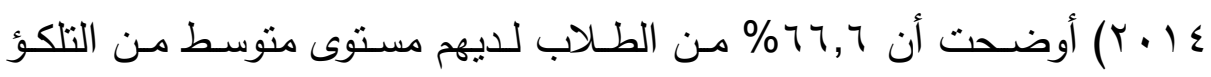
الأكاديمي.

بينما تختلف نتيجة البحث الحالي مـع نتائج دراسـة (1) (Balkis,M.,2011)،

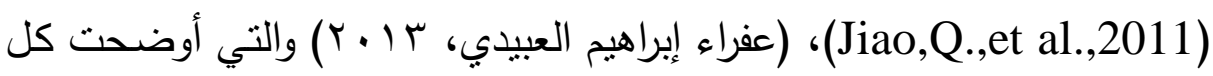
منها وجود مستوى مرتفع من التلكؤ الأكاديمي لدى الطلاب.

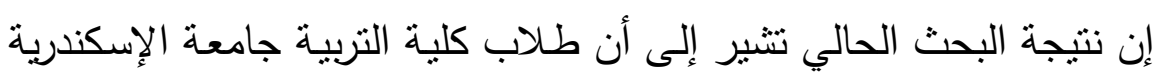

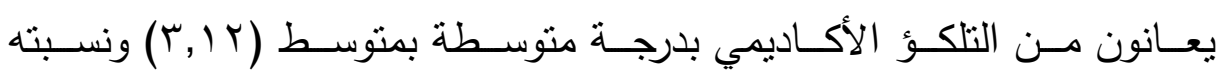

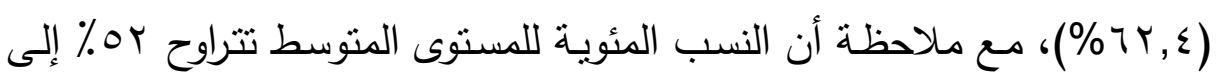

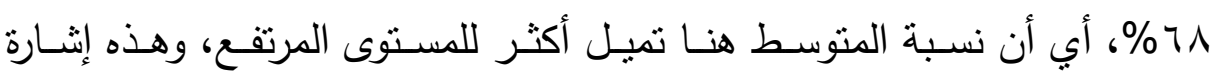

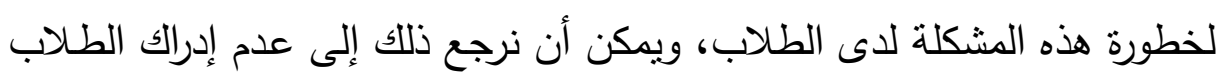

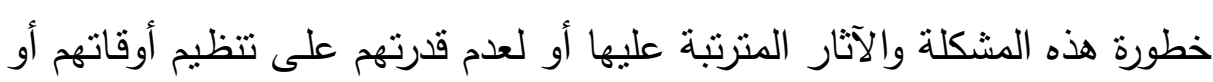
لضعف ثقتهم بأنفسهم. وقد يكون هذا التلكؤ راجعًا لما يتعرض له الطلاب من إحباطات مثل كثثرة

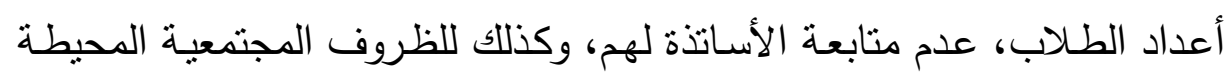

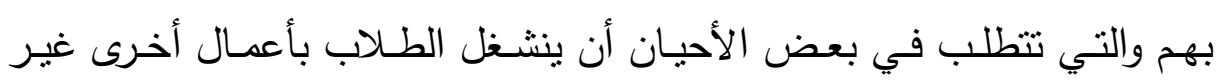
تعليمية سعيًا لطلب الرزق والمعيشة. كما أن عدم اهتمام الكليات بتحفيز طلابهم على الاستخكار الجيد من خلال

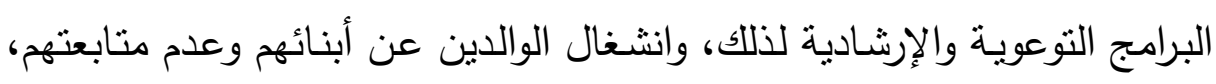

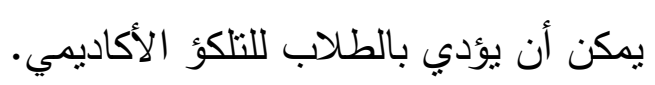

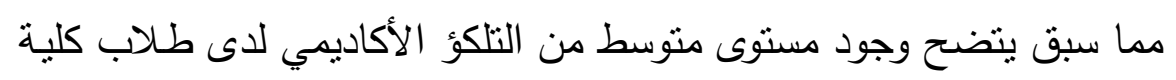
التربية-جامعة، ومن ثم فقد ثم قبول الفرض الأول. نتائج الفرض الثاني ومناقشته ينص الفرض الثاني على أنه "توجد علاقة ارتباطية سلبية بين عادات العقل

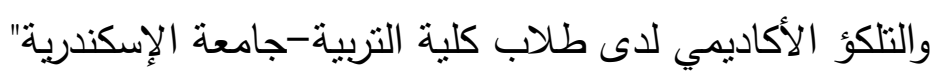


وللتحقق مـن صـحة هذا الفرض تم حسـاب معامـل ارتبـاط "بيرسـون" بين

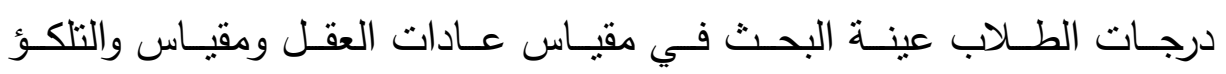
الأكاديمي، والنتائج يوضحها جدول (r) (Y).

\begin{tabular}{|c|c|c|c|c|c|c|}
\hline لعادات العقل الكلة & عادة 0 & عادة ؛ & عادة r ب ك & عادة ب & عادة 1 & عادات العقل \\
\hline .. $\varepsilon r q-$ & .0 rr- & $.+41-$ & ..थ.r- & . rov- & $.0 \leqslant,-$ & لتلكؤ الأكاديمي \\
\hline
\end{tabular}

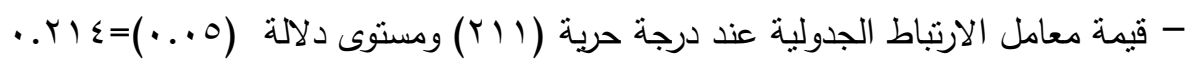

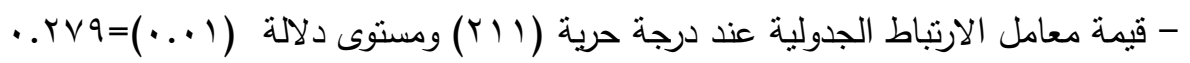

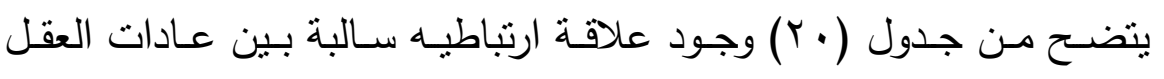

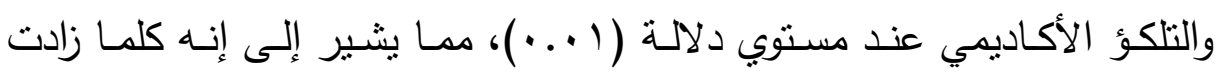
درجات الطلاب عينة البحث في مقياس عادات العقل قلت درجاتهم في مقياس التلكؤ الأكاديمي والعكس صحيح.

لا توجد دراسة في حدود علم الباحث- هدفت لدراسـة العلاقة بين عادات العقل والتلكؤ الأكاديمي، ولكن وجدت دراسات تشير للتأثنير الإيجابي للعادات العقلية على التحصيل والفاعلية الذاتية الأكاديمية، ودافعية الإنجاز ، كما وجدت

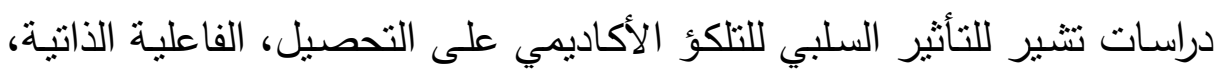
والدافعية.

فقد أكدت دراسـة (Marzano,A.,2000) أن ضـعف عـادات العقل لدى

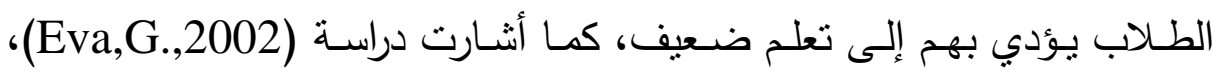

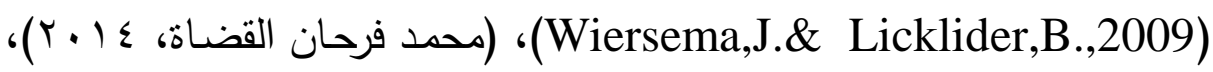

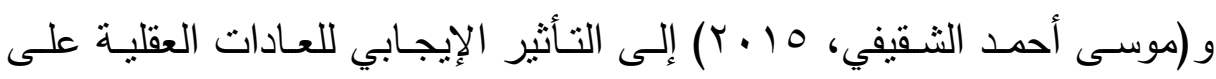

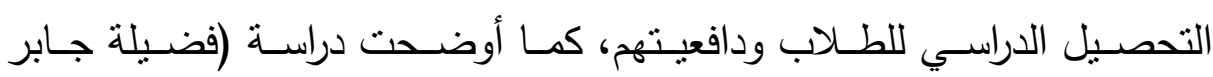

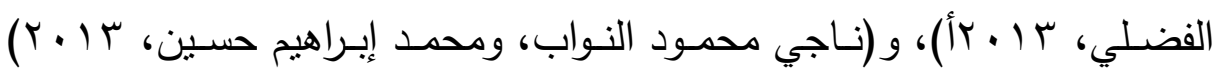
الارتباط الموجب للعادات العقلية بالفاعلية الذاتية للطلاب. 
كichinov,N.et ) (Akinsola,M.et al.,2007) كما أنشارت دراسـة al.,2011) التأثنير السلبي للتنكؤ الأكاديمي على التحصيل الدراسي للطسلاب،

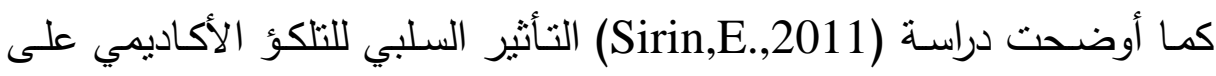
الفاعلية الذاتية والدافعية الأكاديمية للطلاب.

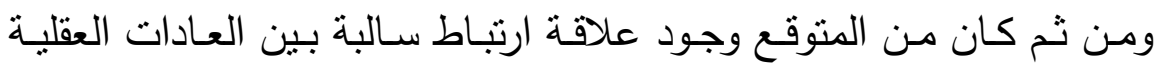

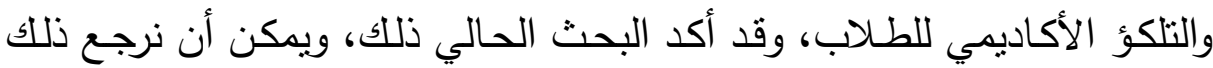

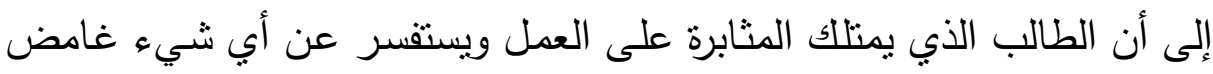

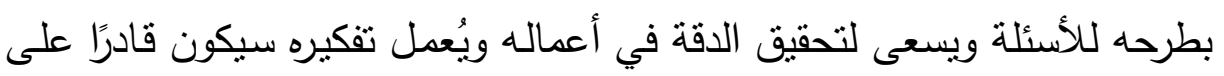
إنجاز مهامه في الوقت المحدد.

ممـا سبق يتضـح وجود علاقـة ارتباطيه سـالبة بين عـادات العقل والتلكؤ

الأكاديمي عند مستوي دلالة ( ( ...)، ومن ثم فقد نم قبول الفرض الثاني.

\section{نتائج الفرض الثالث ومناقشته}

ينص الفرض الثالث على أنه " توجد علاقة ارتباطية إيجابية بين الأفكار

اللاعقلانية والتلكؤ الأكاديمي لدى طلاب كلية التربية- جامعة الإسكندرية".

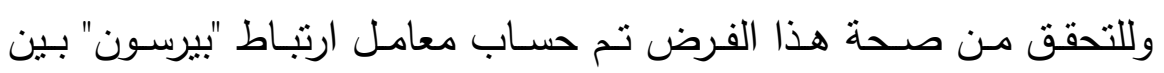

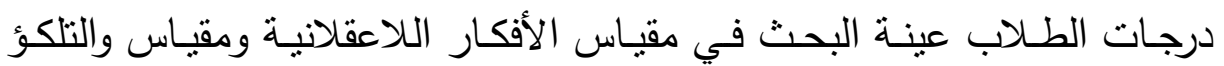
الأكاديمي، والنتائج يوضحها جدول (Y) (Y).

\begin{tabular}{|c|c|c|c|c|c|c|c|c|}
\hline للأفكار اللاعقلانية & فكرة V V V V V & فكرة 1 & فكرة ه & فكرة ؛ & فكرة r & فكرة r & فكرة 1 & الأفكار اللاعقلانية \\
\hline .0 .9 & . & מ & $. r \leqslant v$ & r & . . &..$\Delta \wedge r$ &. $.0 \mathrm{rV}$ & التلكؤ الأكاديمي \\
\hline
\end{tabular}

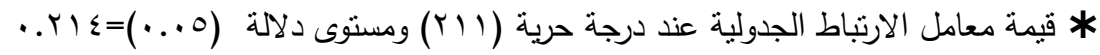

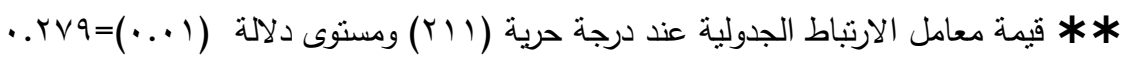

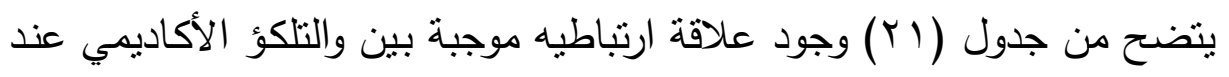

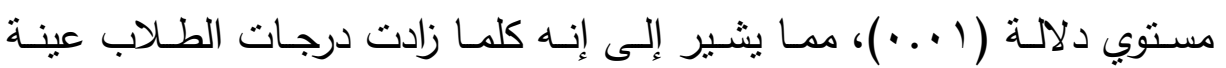


البحث في مقياس الأفكار اللاعقلانية زادت درجاتهم في مقياس التلكؤ الأكاديمي والعكس صحيح.

وتتفـق نتيجـة البحــث الحـالي مـع نتـائج بعـض الدراسـات مثـل دراسـة

Bridgee,K.\&Riog,M.,1997)

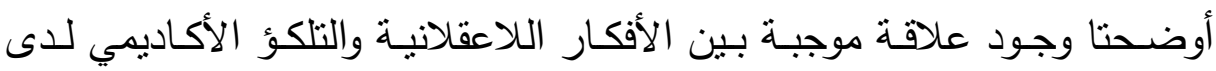
الطلاب، كما أثنارت دراسة (Balkis,M.,2013) إلى وجود علاقة ارتباط سالبة بين التلكؤ الأكاديمي والمعتقدات المعرفية. ويمكن أن نفسر العلاقة الارتباطية الموجبة بين الأفكار اللاعقلانية والتلكؤ الأكاديمي بأن الطلاب المتلكئين نسيطر عليهم بعض الأفكار اللاعقلانية مثل

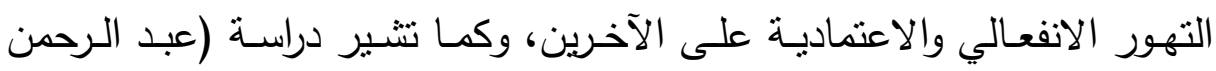

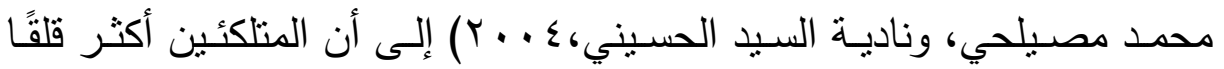
ويتصـفون بوجهـة ضـبط خـارجي، وهـذا يفسـر أيضًا ارتفـاع مسـتوى الأفكـار

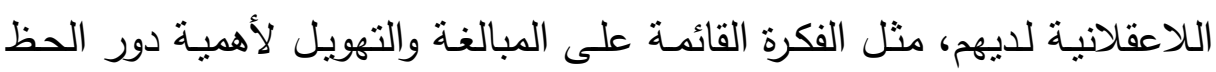
في الحياة وأن ليس للإنسـان يد فيما يدور حوله، فهي دعوة للتكاسل وتأجيل القيام بالمهام المطلوبة. مما سبق يتضح وجود علاقة ارتباطيه موجبة بين الأفكار اللاعقلانية والتلكؤ الأكاديمي عند مستوي دلالة (1 (. •)، ومن ثم فقد تم قبول الفرض الثالث.

\section{نتائج الفرض الرابع ومناقشته}

ينص الفرض الرابع على أنه " لا توجد فروق دالة إحصائًًا في عادات العقل

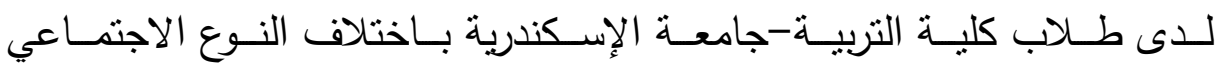
(ذكور /إناث) والتخصص(علمي/أدبي) والتفاعل بينهما".

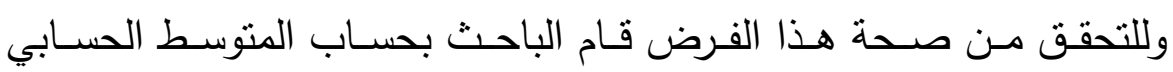
والانحراف المعياري لكل محور من محاور مقياس عادات العقل، كما قام بإجراء

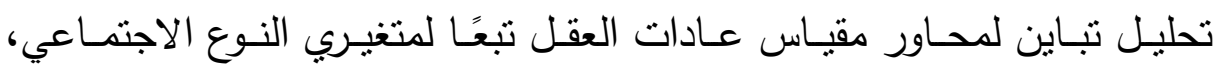
التخصص والتفاعل بينهما والنتائج يوضحها الجدولان(Yr)، (Yr) (Y). 
مجلة الاراسات التربوية والانسانية ـ كلية التربية ـ جامعة دمنهور . المجلد الثامن - العدد(ץ)- لسنة 1 ــץ

جدول (Yr المتوسط الحسابي والانحراف المعياري لمحاور مقياس عادات

العقل تبعاً لمتغيري النوع والتخصص

\begin{tabular}{|c|c|c|c|c|c|c|c|c|}
\hline \multicolumn{4}{|c|}{ إناث (ن= \& ا I) } & & & \multicolumn{2}{|c|}{ ذكور (ن= 9 ( } & \multirow{3}{*}{ العادة العقلية } \\
\hline \multicolumn{2}{|c|}{ أدبي (ن = r O ) } & \multicolumn{2}{|c|}{ علمي (ن = ؟ ؛ ) } & \multicolumn{2}{|c|}{ أدبي (ن = O O ) } & \multicolumn{2}{|c|}{ علمي (ن= = \& ) } & \\
\hline الانحراف & المتوسط & الانحراف & المتوسط & الانحراف & المتوسط & الانحراف & المتوسط & \\
\hline r.r.o & 9.94 & r.7IV & $11 . r 7$ & ס.7ro & $11 . .1$ & 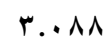 & Ir.AV & عادة \\
\hline$r . \cdot r$ & 9.19 & Y.YA & $9 . \wedge \varepsilon$ & r.Ir & 9.81 & $r .1 r$ & Ir..r & عادة r \\
\hline 1.90 & $11 . r 0$ & r.Aq & 11.11 & r.Ar & 1.99 & r.qr & 1 1r.0. & عادة r \\
\hline Y... $\varepsilon$ & $1 . .77$ & r.r & $1 . . v \leq$ & $r .17$ & $1 . .10$ & r.q. & $1 \mathrm{T.V7}$ & عادة ؛ \\
\hline $1 . \wedge \vee 7$ & $1 \cdot . r$ & r.r. & $1 . .0$ & r.07r & $1 . . \leqslant 7$ & T.YIT & $1 \mathrm{T.0}$ & عادة ه \\
\hline A.r. & $01 . V Y$ & 9.91 & or.or & $1 \cdot . \leqslant r$ & Or.AD & 15.90 & TV.V. & مجمــوع عــادات \\
\hline
\end{tabular}

جدول (rM) نتائج تحليل التباين لمحاور مقياس عادات العقل

\begin{tabular}{|c|c|c|c|c|c|c|}
\hline & قيمة "ف" & \multirow{2}{*}{ متوبط المريعات } & \multirow{2}{*}{ درجات الحرية } & \multirow{2}{*}{ مجموع المريعات } & \multirow{2}{*}{ مصدر الاختلاف } & \multirow{2}{*}{ المحور } \\
\hline الدالة & القيمة & & & & & \\
\hline$\ldots \cdot 1$ & r...v & 178.74 & 1 & 178.74 & النوع & \multirow{5}{*}{ المثابرة } \\
\hline$\ldots 0$ & $\varepsilon . \mu r$ & $r 19.1 r$ & 1 & r $19.1 r$ & التخصص & \\
\hline$\ldots 1$ & rr..V & ra.01 & 1 & r9.01 & النوع×التخصص & \\
\hline-- & -- & $\checkmark . \wedge r$ & $r \cdot \Lambda$ & $1 \leq Y 1 . Y 4$ & الخطأ & \\
\hline-- & -- & -- & YI & IArv.or & مجموع & \\
\hline$\ldots 1$ & 10.49 & $11 \leqslant .0 \mathrm{~V}$ & 1 & $11 \leqslant .0 \mathrm{~V}$ & النوع & \multirow{5}{*}{ التفكيــر } \\
\hline$\ldots 1$ & 11.17 & $1 \mathrm{tr}$ & 1 & $1 \mathrm{p} 0.1 \mathrm{r}$ & التخصص & \\
\hline$\ldots 1$ & $11 . \leqslant 0$ & Irv.r. & 1 & Irv.r. & النوع×التخصص & \\
\hline-- & -- & $V . \varepsilon \varepsilon$ & $r \cdot \Lambda$ & $10 \leqslant \wedge .11$ & الخطأ & \\
\hline-- & -- & -- & YI & 1940.11 & مجموع & \\
\hline$\cdots 1$ & V.ru & $\leq 9.1 \mathrm{~V}$ & 1 & $\leqslant 9.1 \mathrm{~V}$ & النوع & \multirow{5}{*}{ الأسئلة ألة } \\
\hline$\cdots \cdot 1$ & $11 . v \leq$ & VA.rq & 1 & VA.rq & التخصص & \\
\hline$\ldots \cdot 1$ & $\mid r . .1$ & $\wedge \neg . \wedge r$ & 1 & $\wedge \neg . \wedge r$ & النوع×التخصص & \\
\hline-- & -- & 7.71 & $r \cdot \Lambda$ & $1 \% \wedge 9.10$ & الخطأ & \\
\hline-- & -- & -- & 11 & $17 . r .04$ & مجموع & \\
\hline
\end{tabular}




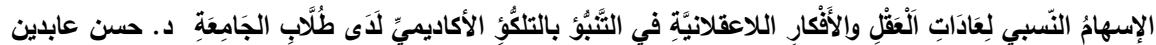

\begin{tabular}{|c|c|c|c|c|c|c|}
\hline & قيمة "ف" & \multirow{2}{*}{ متوسط المريعات } & \multirow{2}{*}{ درجات الحرية } & \multirow{2}{*}{ مجموع المربعات } & \multirow{2}{*}{ مصدر الاختلاف } & \multirow{2}{*}{ المحور } \\
\hline الالالة & القيمة & & & & & \\
\hline$\cdots 1$ & $10.0 \mathrm{~V}$ & $|r . . v|$ & 1 & $|r . v|$ & النوع & \multirow{5}{*}{ التبفيـل } \\
\hline$\ldots 1$ & $\mid 0 . M 1$ & 111.71 & 1 & 111.71 & التخصص & \\
\hline$\cdots 1$ & Ir.VA & 1.7 .17 & 1 & 1.7 .17 & النوع×|التخصص & \\
\hline-- & -- & V.Vo & $r \cdot \Lambda$ & 1714.09 & الخطأ & \\
\hline-- & -- & -- & YI & $190 \wedge . \wedge \varepsilon$ & مجموع & \\
\hline$\cdots 1$ & $r \leq . \Lambda$. & $10 . . \leqslant r$ & 1 & $10 \ldots \leqslant r$ & النوع & \multirow{5}{*}{ السن أجلـي } \\
\hline$\cdots 1$ & 10.91 & 108.17 & 1 & 108.17 & التخصص & \\
\hline$\ldots 1$ & $14.9 \leq$ & $\Lambda \leq .0 \mathrm{~V}$ & 1 & $\wedge \leq . \diamond V$ & النوع×التخصص & \\
\hline-- & -- & $7 .+V$ & $r \cdot \Lambda$ & $|Y 7| . V \wedge$ & الخطأ & \\
\hline-- & -- & -- & YII & $1704.9 \leq$ & مجموع & \\
\hline$\cdots 1$ & r..17 & $\mathrm{r} 9.7 . \wedge \mathrm{V}$ & 1 & Yq. ४.Av & النوع & \multirow{5}{*}{ العــــــادع } \\
\hline$\cdots 1$ & $r 1 . . r$ & $r \leq \varepsilon V . .7$ & 1 & $r \leq \varepsilon V . .7$ & التخصص & \\
\hline$\cdots 1$ & $19 . .5$ & $r 117 . . r$ & 1 & $r 117 . . r$ & النوع×التخصص & \\
\hline-- & -- & $111.1 \%$ & $r \cdot \Lambda$ & rMIIR.IA & الخطأ & \\
\hline-- & -- & -- & YI & rlonr.1E & مجموع & \\
\hline
\end{tabular}

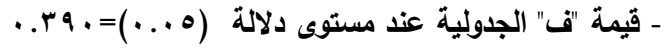

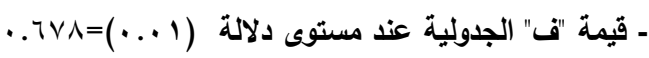

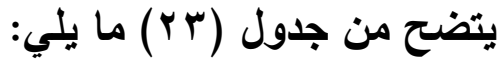

وجود فروق دالة إحصائيًا في عادةا (المثنابرة) وفقًا لمتغير النوع (ذكور /

إناث) عند مستوى دلالة (1 (...) لصالح الذكور، ووجود فروق دالة إحصائًًا في

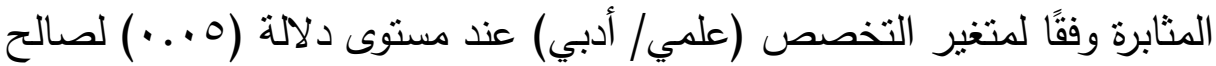
التخصص العلمي، بالإضـافة إلى وجود فروق دالة إحصـائيًا في المثنابرة تبعًا للتفاعل بين متغيري النوع والتخصص عند مستوى دلالة ( ( ...) لصالح ذكور علمي.

وجود فروق دالة إحصائيًا في عادةץ (التفكير في التفكير) وفقًا لمتغير النوع

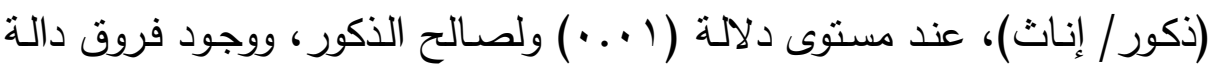




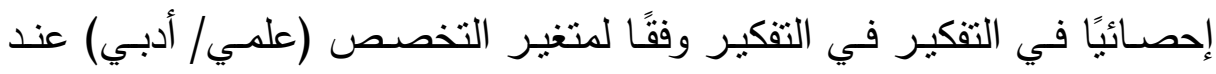

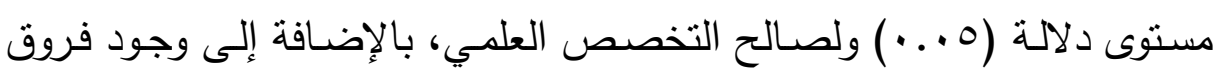

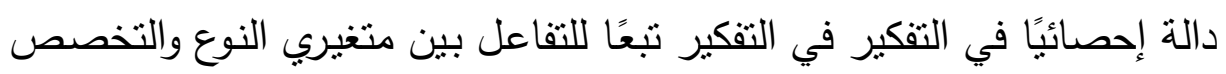

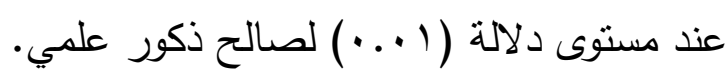

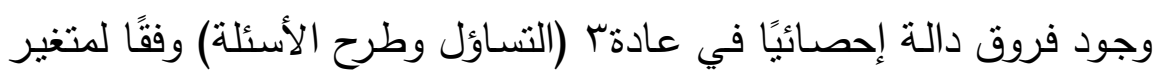

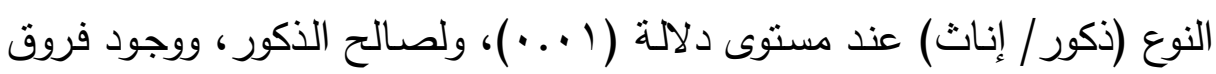

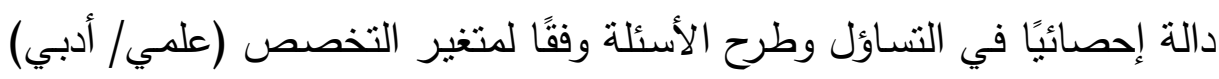

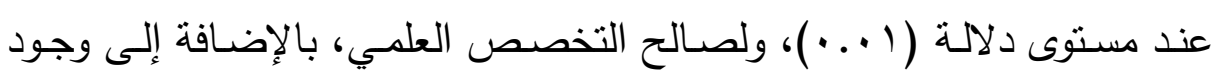

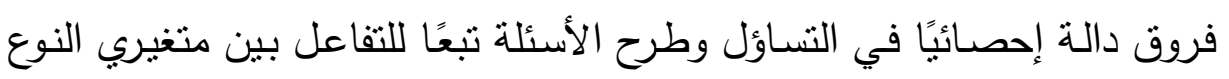
والتخصص عند مستوى دلالة ( ( ...) لصالح ذكور علمي.

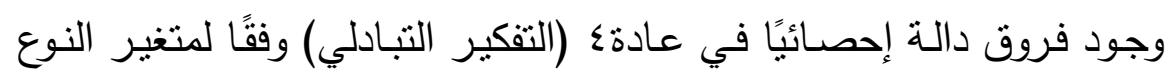

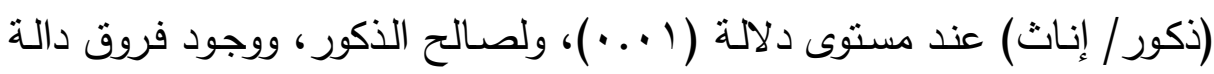

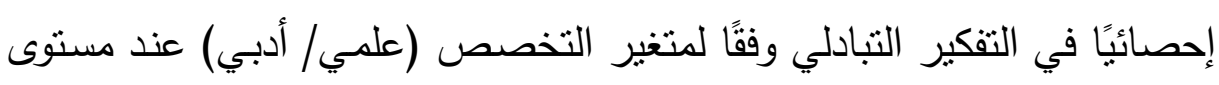

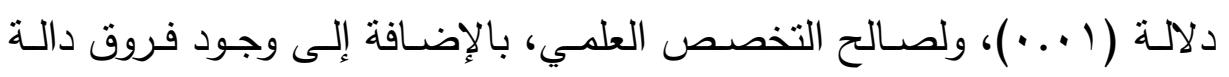

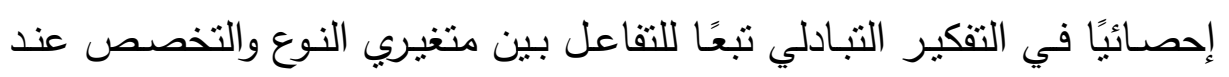
مستوى دلالة (1 (...) لصالح ذكور علمي. وجود فروق دالة إحصائيًا في عادةه (السعي من أجل الدقة الدئ) وفقًا لمتغير

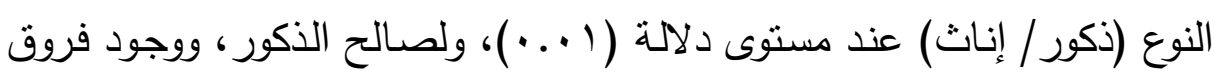

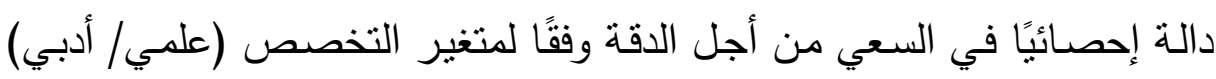

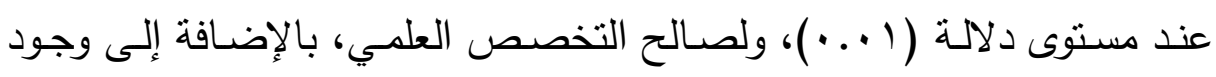

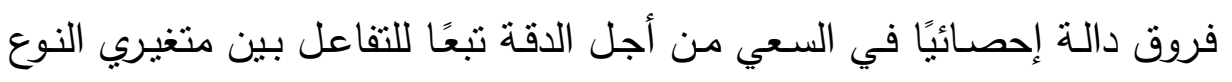

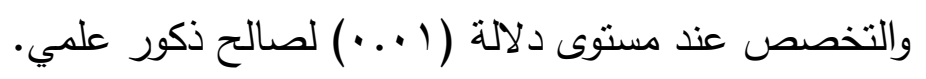

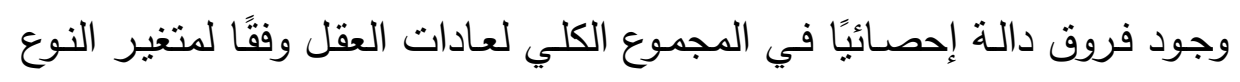

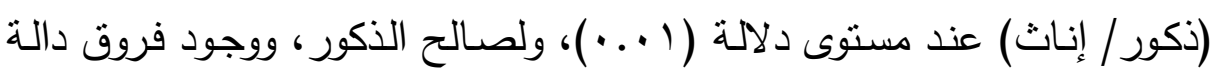

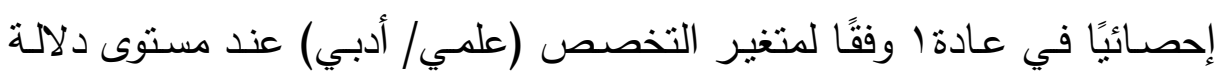


( ( · ·)، ولصالح التخصص العلمي، بالإضافة إلى وجود فروق دالة إحصائيًا

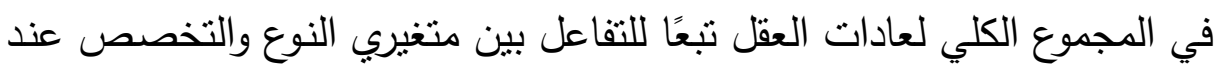

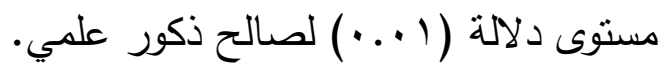

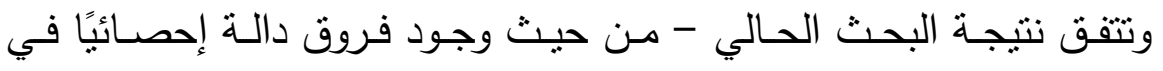

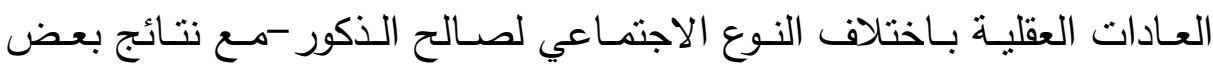

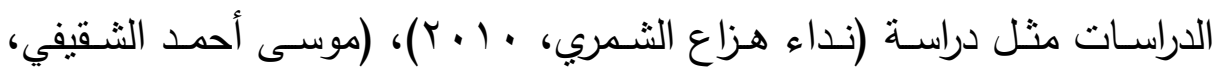

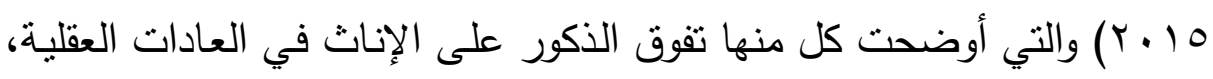

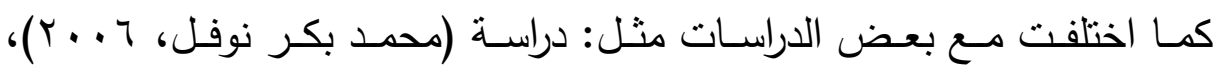

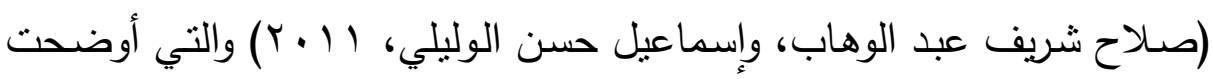
كل منهما عدم وجود فروق بين الذكور والإناث في العادات العقلية. ويمكن أن نرجع تفوق الذكور على الإناث في العادات العقلية إلى طبيعة لئه الذكور من كثرة تعاملاتهم وانفتاحهم على من حولهم، فهم أكثر الكثر نواجدًا خارج

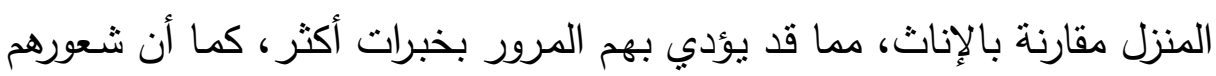

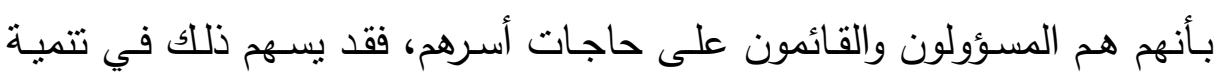
بعض العادات العقلية لديهم من مثابرة والتفكير في التفكير والتساؤل والاستفسار عن الأشياء الغامضة من حولهم.

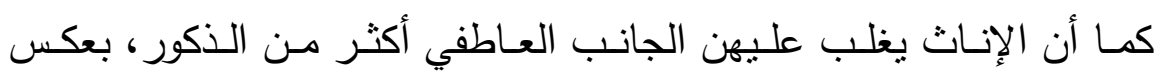

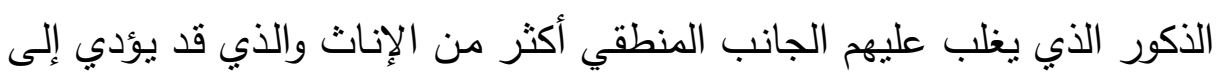
تفوق الذكور عن الإناث في بعض العادات العقلية.

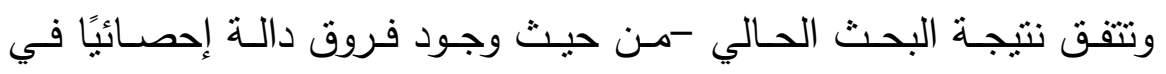

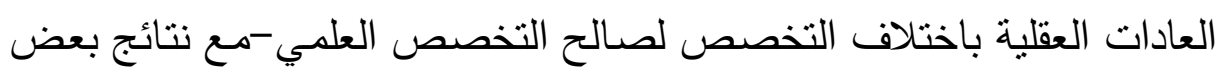

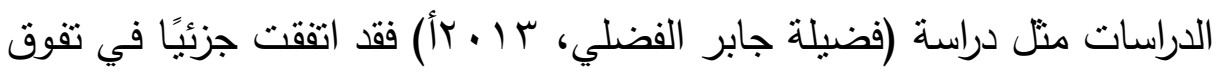

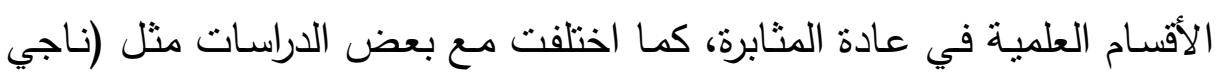

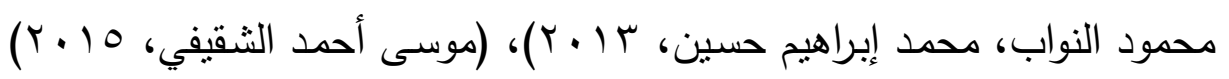


والتي أوضحت كل منها عدم وجود فروق في العادات العقلية بين الأقسام العلمية والأدبية.

ويمكن أن نرجع تفوق الأقسام العلمية على الأدبية في العادات العقلية إلى الى العاده

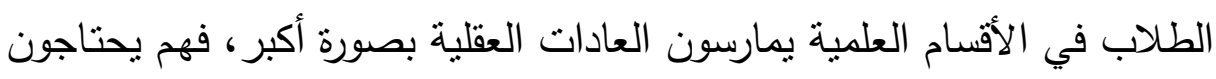
لتحري الدقة والمثابرة والتفكير في التفكير بصورة أوضح من الأقسام الأدبية، أي لطي

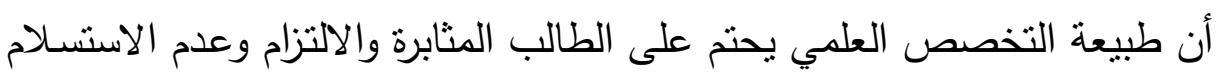
والقدرة على حل المشكلات، فعند حل مسألة حسابية لابد من التعامل معها بدقة الطئة

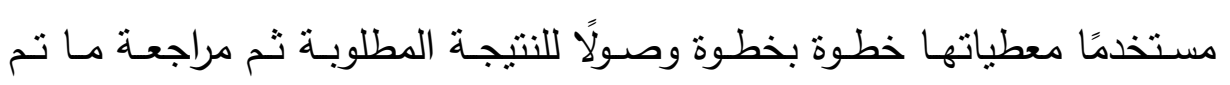

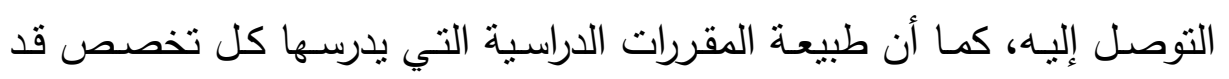

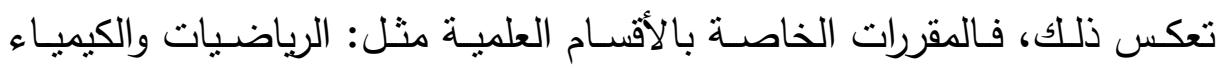
والفيزياء تتطلب الدقة والقدرة على حل المشكلات والمثابرة والتفكير في التفكير بصورة أوضح من مقررات الأقسام الأدبية.

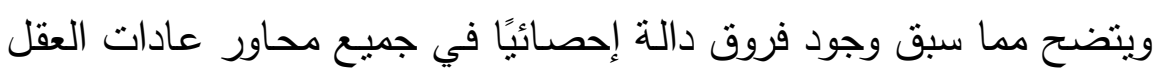

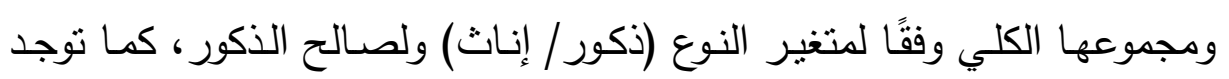

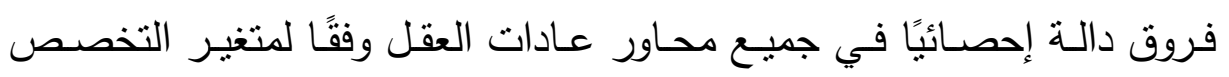

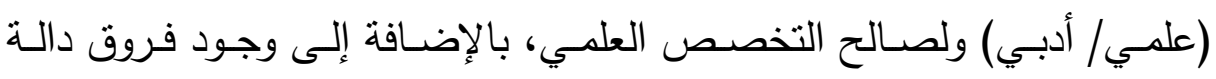

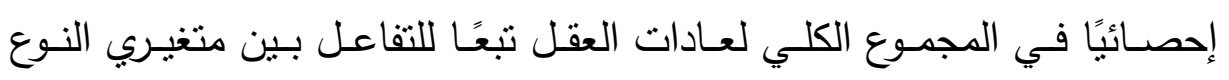

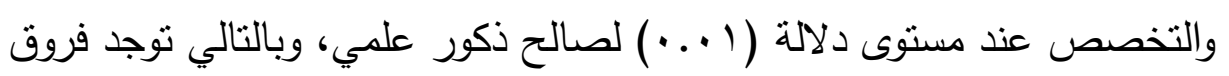

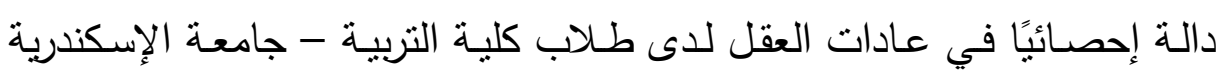

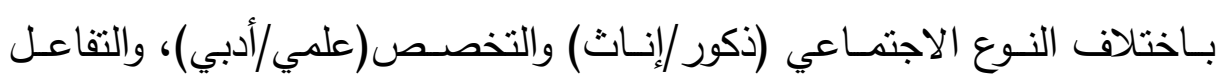
بينهما، ومن ثم فقد نم رفض الفرض الرابع وقبول الفرض البداعيل. 


\section{نتائج الفرض الخامس ومناقشته}

ينص الفرض الخامس على أنه "لا توجد فروق دالة إحصـائيًا في الأفكار

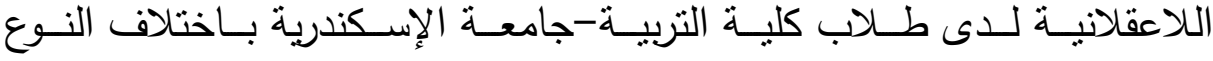

الاجنماعي (ذكور//إناث) والتخصص(علمي/أدبي) والتفاعل بينهما".

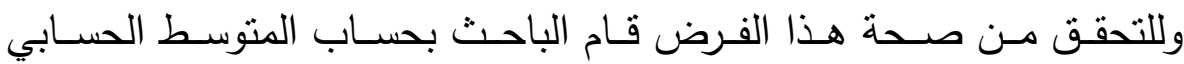
والانحراف المعياري لكل محور من محاور مقياس الأفكار اللاعقلانية، كما قام بـإجراء تحليل تبـاين لمحساور مقيـاس الأفكار اللاعقلانيـة تبعًا لمتغيـري النـوع الاجتماعي، التخصص والتقاعل بينهما والنتائج يوضحها الجدولان( ؟ Y)، (Yo). جدول ( § Y) المتوسط الحسابي والانحراف المعياري لمحاور مقياس الأفكار التلاعقلانية تبعاً لمتغيري النوع والتخصص ولايطري

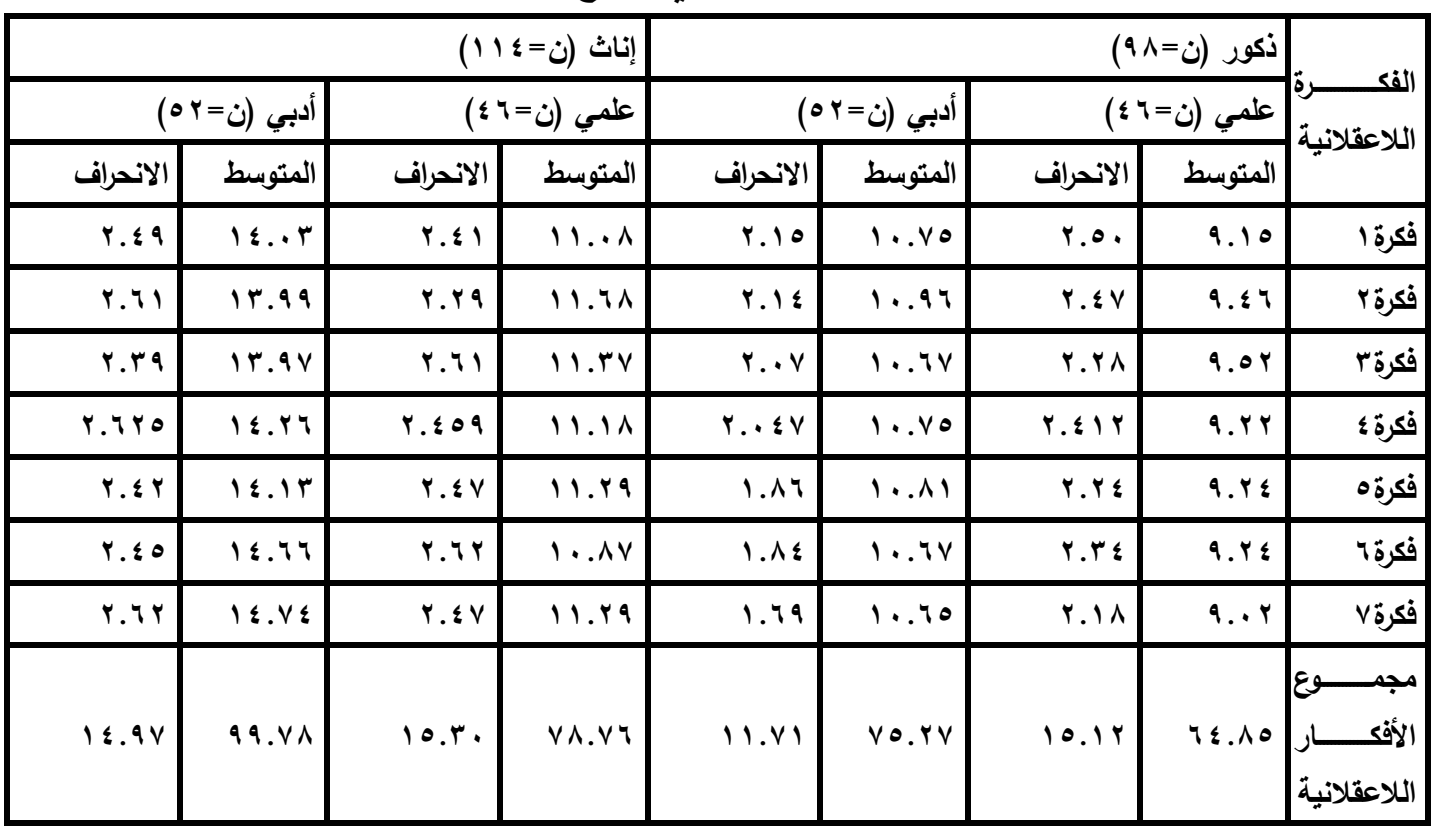

جدول (Y0) نتائج تحليل التباين لمحاور مقياس الأفكار اللاعقلانية ومجموعها

الكلي

\begin{tabular}{|c|c|c|c|c|c|c|}
\hline & قيمة "ف' & متوســــــــــ & درجـــــــــــات & & & \\
\hline الدلالة & القيمة & المريعات & الحرية & & & \\
\hline$\ldots 1$ & $0 \wedge . \leqslant 1$ & sT.0 & 1 & Fr & النوع & طل ـــــبـ \\
\hline
\end{tabular}




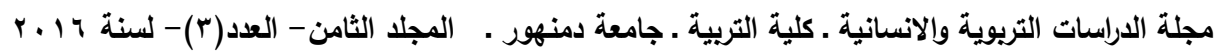

\begin{tabular}{|c|c|c|c|c|c|c|}
\hline & قيمة "ف" & \multirow[t]{2}{*}{ 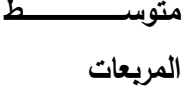 } & \multirow{2}{*}{ درجية الحرية } & \multirow{2}{*}{ مجموع المريعات } & \multirow{2}{*}{ مصدر الاختلاف } & \multirow{6}{*}{ الاستحسان } \\
\hline الدلالة & القيمة & & & & & \\
\hline$\ldots 1$ & $\varepsilon \varepsilon .0 \mathrm{~V}$ & ห०५.AI & 1 & Y०५.A1 & التخصص & \\
\hline$\ldots 0$ & $r .9 r$ & r.t. & 1 & r.T.TE & النوع × التخصص & \\
\hline-- & -- & 0.17 & $r \cdot \Lambda$ & $119 \wedge . \varepsilon$. & الخطأ & \\
\hline-- & -- & -- & 11 & $1 \wedge \mid \leq . r q$ & مجموع & \\
\hline$\cdots 1$ & $\bullet \wedge . \wedge \leq$ & $r \leq r . . r$ & 1 & $r \leq r . . r$ & النوع & \\
\hline$\cdots 1$ & $r .9 r$ & IA..rr & 1 & $1 \wedge . . r r$ & التخصص & الاعتمادية \\
\hline غير دالة & $1 . r q$ & 8.91 & 1 & V.91 & النوع × التخصص & \\
\hline-- & -- & $0 . \wedge r$ & $r \cdot \Lambda$ & IrIr.or & الخطأ & \\
\hline-- & -- & -- & YI & $1 v \leq 4.79$ & مجموع & \\
\hline$\cdots 1$ & Y..MY & rrq.rq & 1 & צ'r.ru & النوع & \\
\hline$\ldots 1$ & rr.lr & IVo. $\leqslant r$ & 1 & IV $v . \leqslant$ & التخصص & \\
\hline$\ldots 0$ & $\varepsilon . \wedge 1$ & rצ.r^ & 1 & rצ.rA & التوع × التخصص & \\
\hline-- & -- & $0 . \leqslant 7$ & $r \cdot \Lambda$ & $\mid 1 r 0 . v 1$ & الخطأ & \\
\hline-- & -- & -- & YI & $1774 . \vee \wedge$ & مجموع & \\
\hline$\ldots 1$ & Y.人o & rVr.ru & 1 & rVr.ru & النوع & \\
\hline$\ldots 1$ & \&O.rY & צr.r & 1 & צr.r. & التخصص & علاق \\
\hline$\ldots 0$ & $0 . .1$ & rq.Vr & 1 & rq.V r & النوع × التخصص & الرجــــــــل \\
\hline-- & -- & $0 . \wedge 0$ & $r \cdot \Lambda$ & $1 r 17 . . r$ & الخطأ & بالمرأة \\
\hline-- & -- & -- & 11 & IANT.\&l & مجموع & \\
\hline$\cdots 1$ & 79.19 & roq.. \& & 1 & roq.. \& & النوع & \\
\hline$\cdots 1$ & $\leqslant V . .7$ & $r \leqslant 1 . \wedge r$ & 1 & $r \leq 1 . \wedge r$ & التخصص & \\
\hline$\ldots 0$ & r.qr & $r .17$ & 1 & $r .17$ & التوع × التخصص & \\
\hline-- & -- & $0.1 \leq$ & $r \cdot \Lambda$ & 1.71 .90 & الخطأ & \\
\hline-- & -- & -- & MI & 1719.91 & مجموع & \\
\hline$\cdots 1$ & VY.OD & Mal.Al & 1 & Mal. 1 & النوع & \\
\hline$\cdots 1$ & YY.AI & rrq.iv & 1 & rrq.iv & التخصص & \\
\hline$\cdots 1$ & I Y.VV & $7 \wedge .9 \vee$ & 1 & $7 \wedge .9 \mathrm{~V}$ & النوع × التخصص & \\
\hline-- & -- & $0 . \varepsilon$. & $r \cdot \Lambda$ & rq1.11 & الخطأ & \\
\hline-- & -- & -- & YI & 1191.27 & مجموع & \\
\hline
\end{tabular}




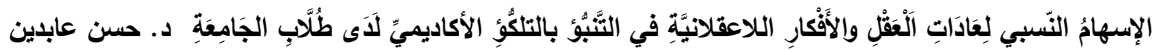

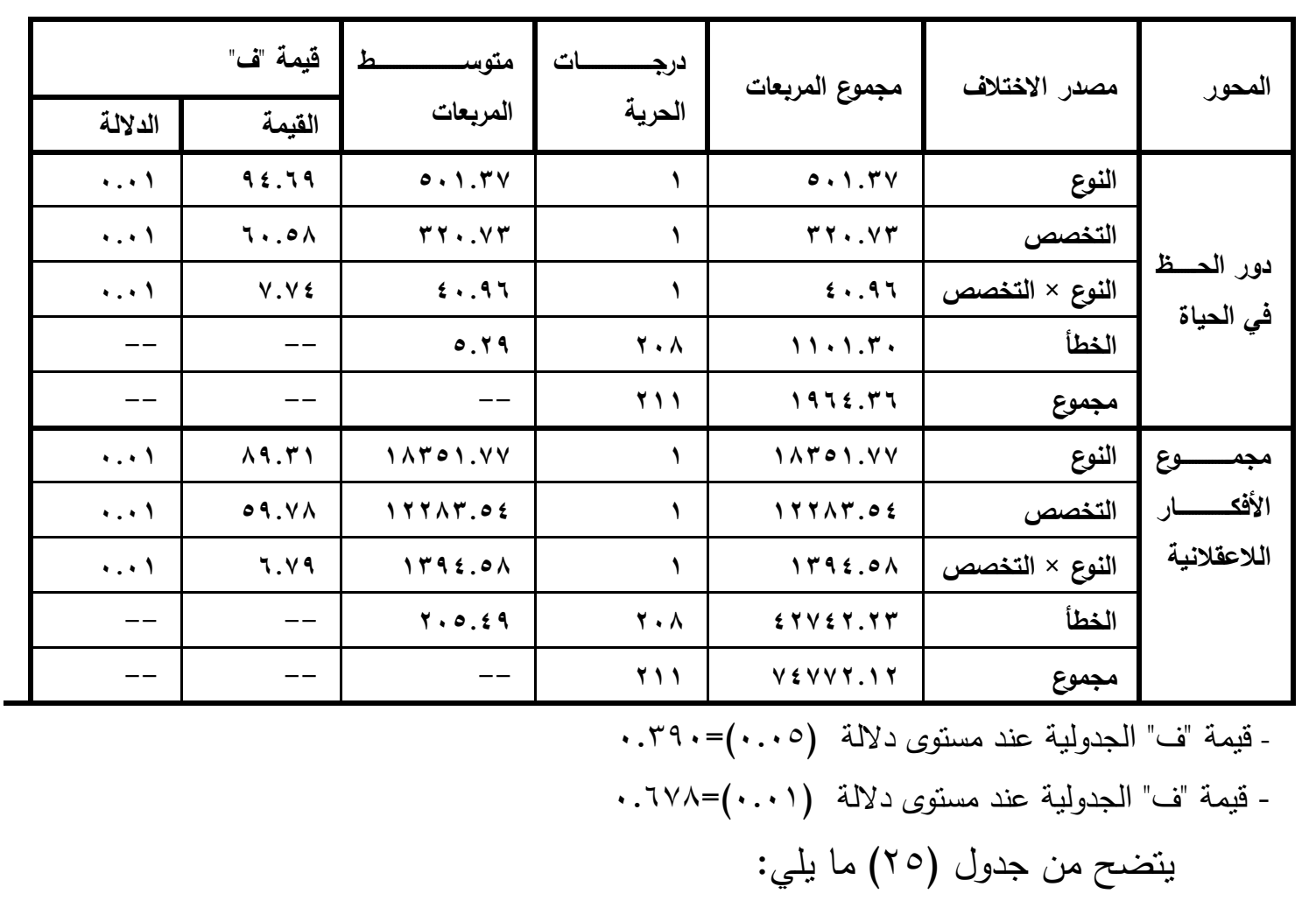

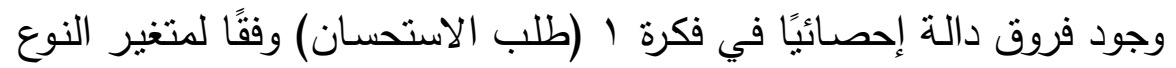

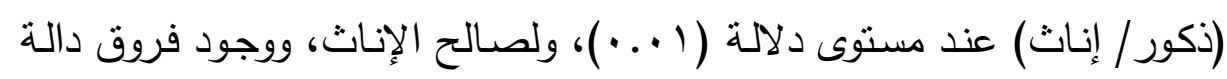

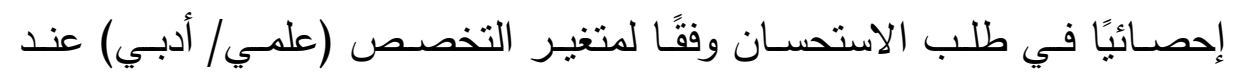

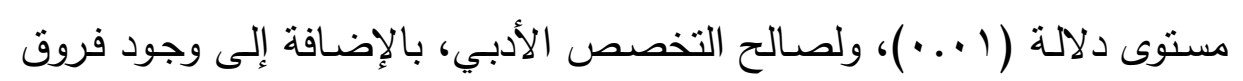

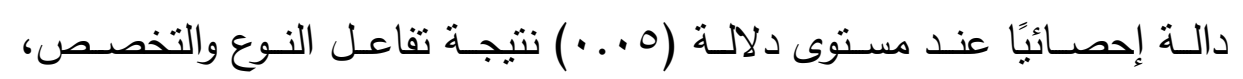
ولصالح إناث أدبي.

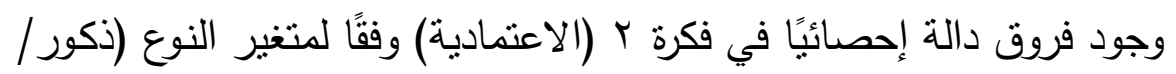
إناث)، عند مستوى دلالة (1 (. •) ولصالح الإناث، ووجود فروق دالة إحصائيًا

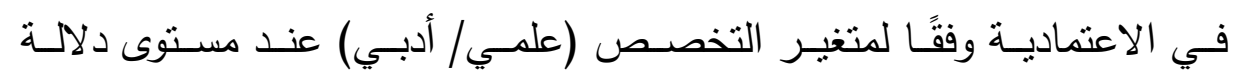

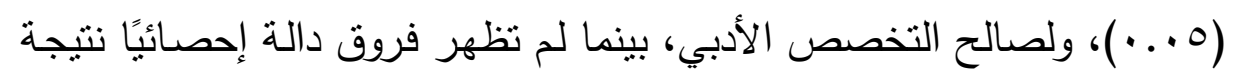

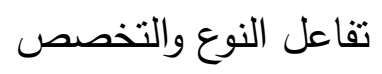




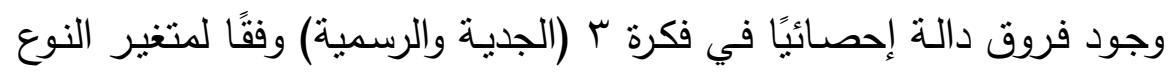

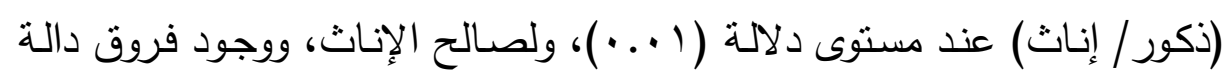

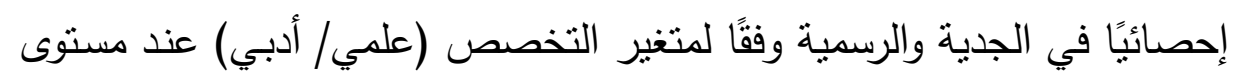

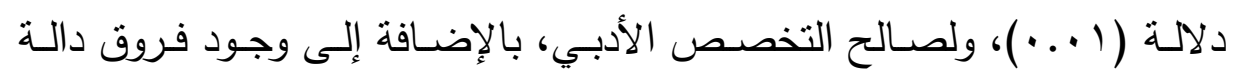

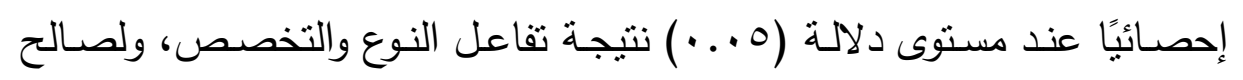
إناث أدبي. وجود فروق دالة إحصـائيًا في فكرة ؛ (علاقة الرجل بالمرأة) وفقًا لمتغير

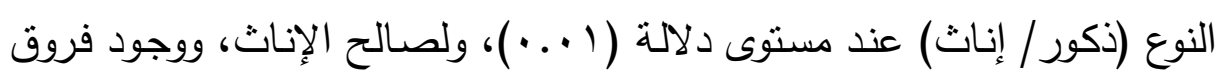

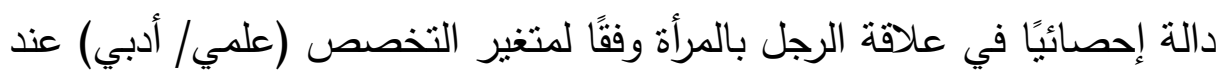

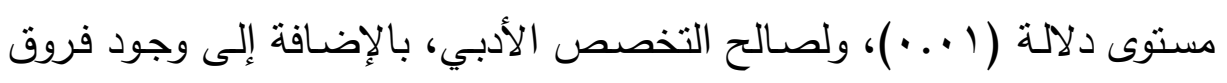

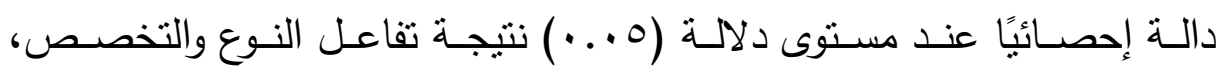
ولصالح إناث أدبي. وجود فروق دالة إحصائًا في فكرة ه (تجنب المشكلات) وفقًا لمتغير النوع

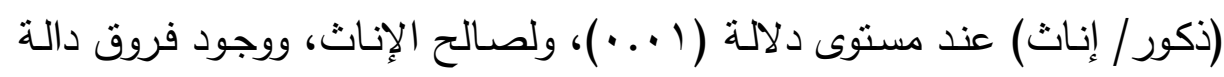

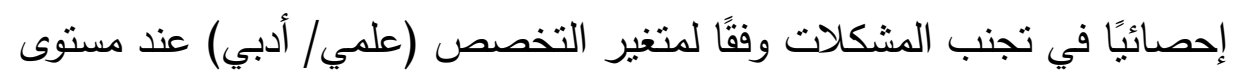

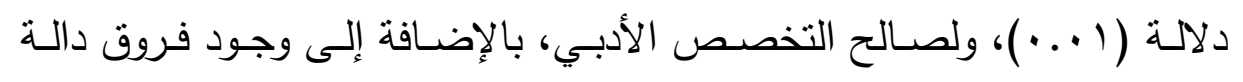

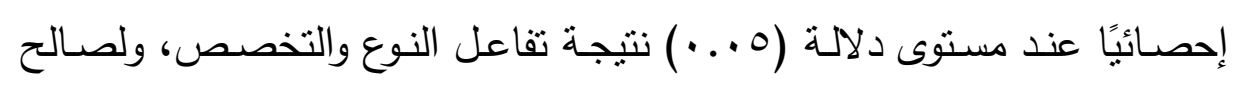
إناث أدبي.

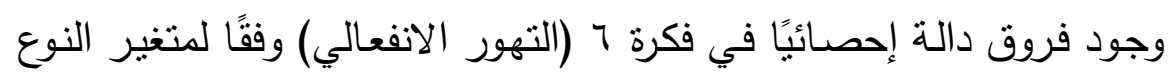

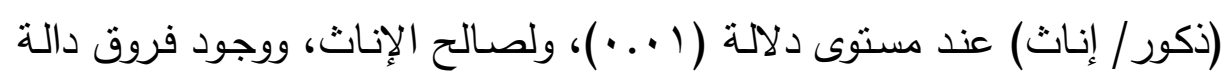

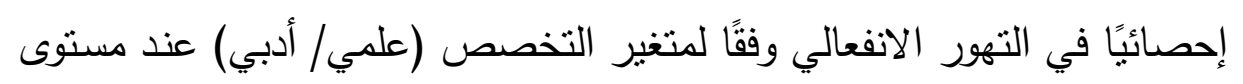

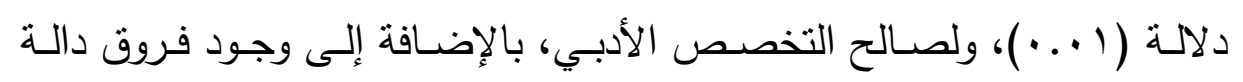

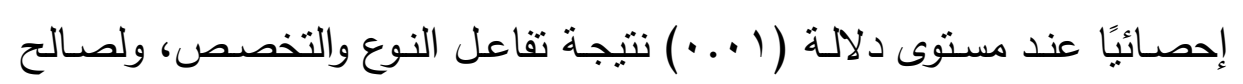
إناث أدبي. 
وجود فروق دالة إحصائيًا في فكرة > (دور الحظ في الحياة) وفقًا لمتغير

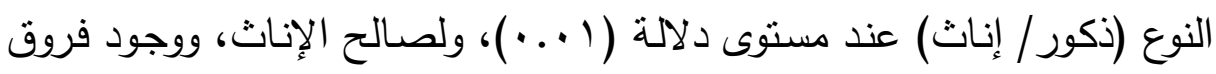

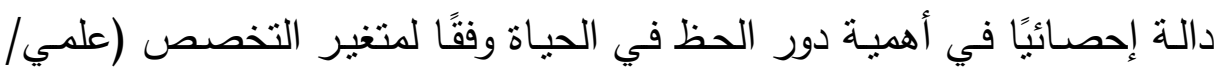

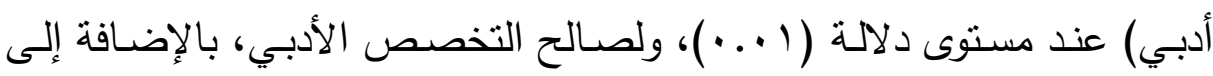

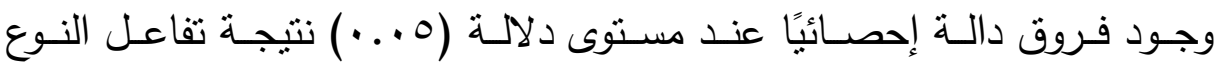
والتخصص، ولصالح إناث أدبي.

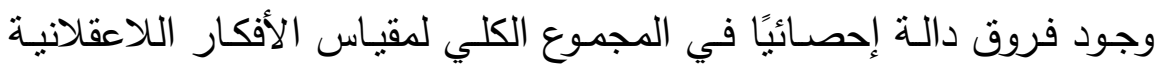

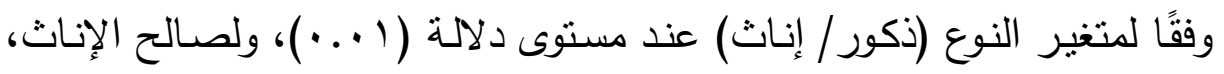

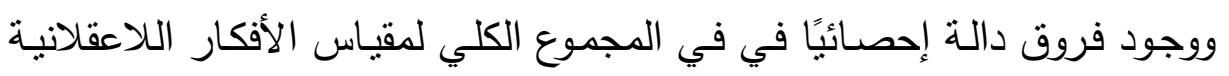

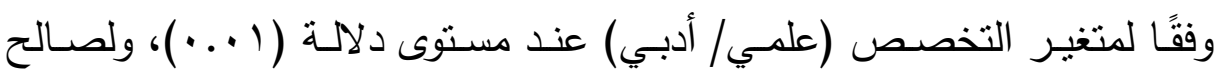
التخصص الأدبي، بالإضافة إلى وجود فروق دالة إحصائيًا عند مستوى دلالية (0 . . ) نتيجة تفاعل النوع والتخصص، ولصالح إناث أدبي.

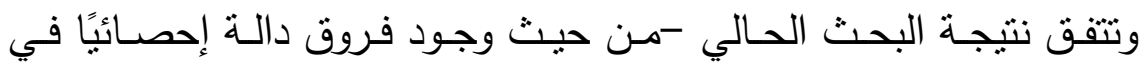

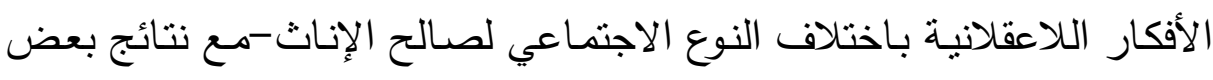

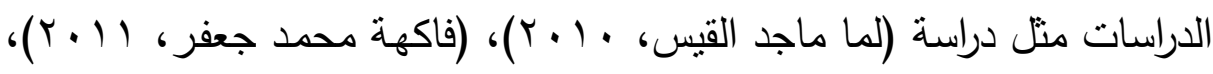

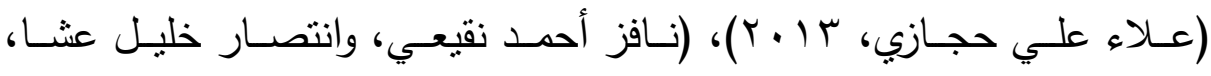

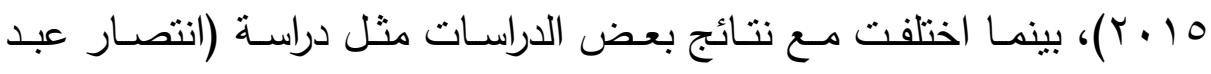

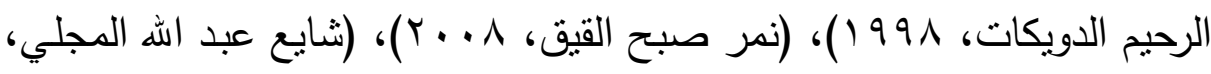

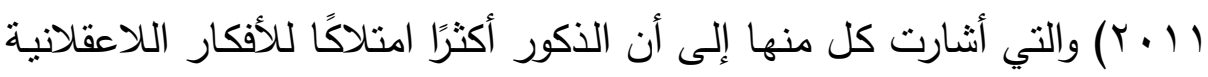

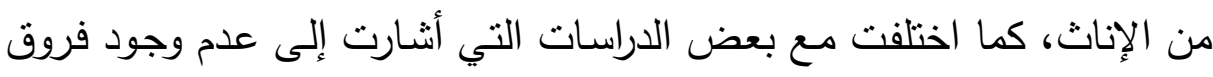
دالة إحصائًًا بين الذكور والإناث في الأفكار اللاعقلانية منل دراسة (فراس أحمد الإني الحموري، با • (Y)، (Ozer,E.\&Akgun,O.,2015).

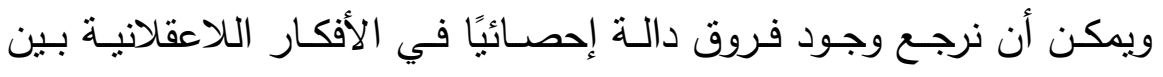

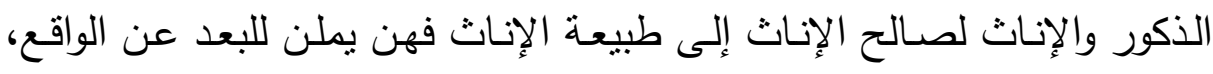

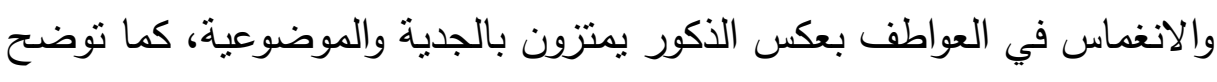


دراسة (Sherry,S., et al., 2003) أن الإناث أكثر اعتمادية من الذكور، قد

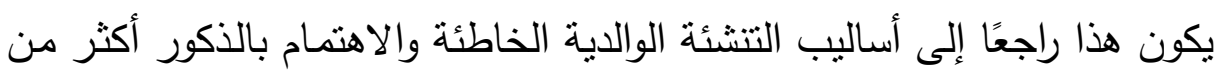

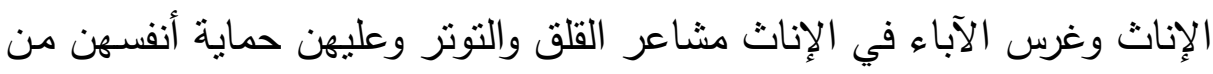

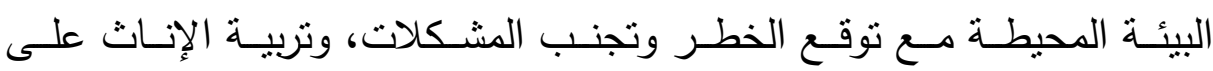
الاعتمادية مع محاولة إرضاء من حولهن كي يكن مقبولات اجتماعيًا.

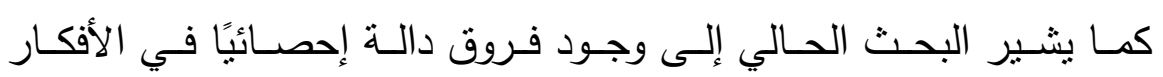

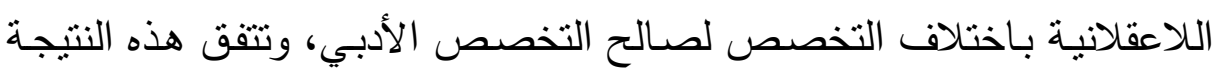

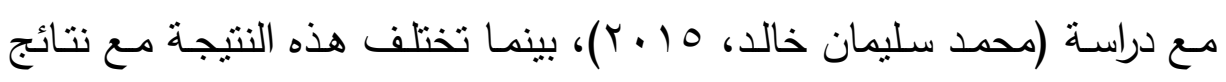

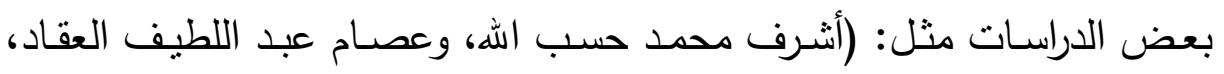

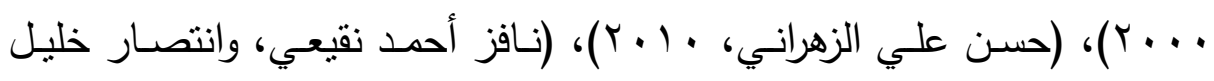

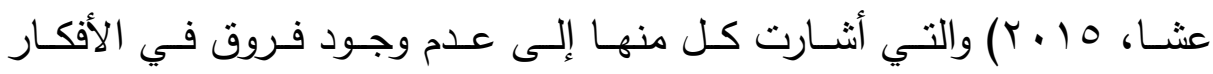
اللاعقلانية تبعًا للتخصص. ويمكن أن نرجـع وجود فروق دالـة إحصـائيًا في الأفكار اللاعقلانيـة بين

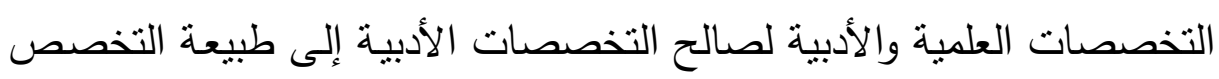

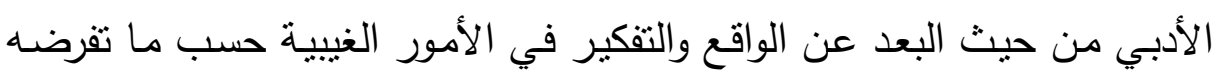

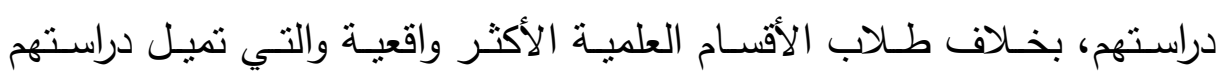
للتجريب والمنطقية.

ويتضـح مما سبق إنها توجد فروق دالة إحصائًا في جميع محاور مقياس الأفكار اللاعقلانية ومجموعها الكلي وفقًا لمتغير النوع الاجتماعي (ذكور/إناث)

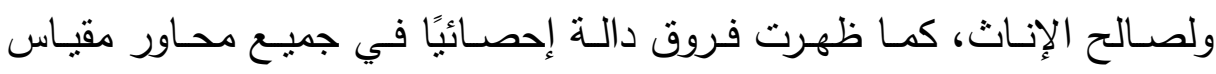

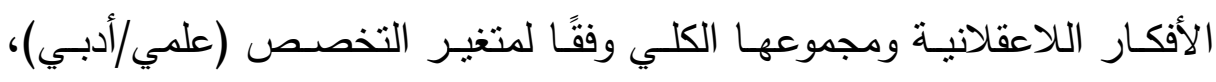

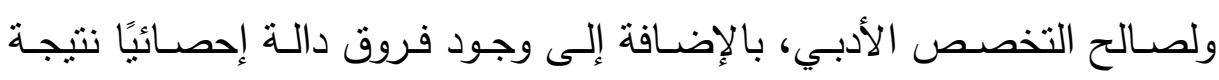
تفاعل النوع والتخصص لجميع محاور مقياس الأفكار اللاعقلانيـة ومجموعها الكلي ماعدا محور فكرة (r) (الاعتمادية)، حيث لم تظهر فروق دالة إحصائًا نتيجة التفاعل، ومن ثم فقد تم قبول الفرض الخامس جزئيًا. 
نتائج الفرض السادس ومناقشته يـنص الفـرض السـادس على أنـه " لا توجـد فروق دالـة إحصـائيًا في التلكؤ

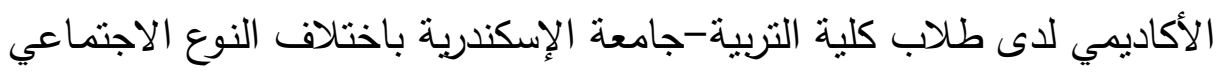
(ذكور /إناث) والتخصص(علمي/أدبي) والتفاعل بينهما".

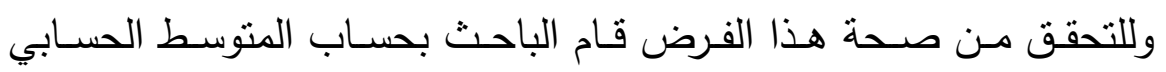
والانحراف المعيـاري لمقيـاس التلكؤ الأكـاديمي، كمـا قـام بـإجراء تحليـل تبـاين لمقياس التلكؤ الأكاديمي تبعًا لمتغيري النوع، التخصص التصبي والتفاعل بينهما والنتائج

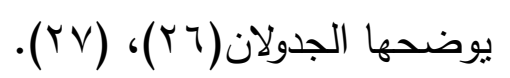

جدول (Y Y (المتوسط الحسابي والانحراف المعياري لمقياس التلكؤ الأكاديمي

تبعاً لمتغيري النوع والتخصص

\begin{tabular}{|c|c|c|c|c|c|c|c|c|}
\hline \multicolumn{4}{|c|}{ إناث (ن= \& 11 ) } & \multicolumn{4}{|c|}{ ذكور (ن=a^) } & \multirow{3}{*}{ المتغير } \\
\hline \multicolumn{2}{|c|}{ أدبي (ن = V } & \multicolumn{2}{|c|}{ علمي (ن= = } & \multicolumn{2}{|c|}{ أدبي (ن = O O ) } & \multicolumn{2}{|c|}{ علمي (ن= = ؛ ) } & \\
\hline الانحراف & المتوسط & الانحراف & المتوسط & الانحراف & المتوسط & الانحراف & المتوسط & \\
\hline Ir.vvq & 人ч.rrq & 1..ors & $0 \leqslant . r \leqslant r$ & $\mid$ r.va| & ג & YY.r. T & $91.1 . \varepsilon$ & الأكادئ مقياس \\
\hline
\end{tabular}

جدول (rV) نتائج تحليل التباين لمقياس التلكؤ الأكاديمي

\begin{tabular}{|c|c|c|c|c|c|c|}
\hline \multicolumn{2}{|c|}{ قيمة "ف" } & \multirow{2}{*}{ متوسط المربعات } & \multirow{2}{*}{ دالحرية } & \multirow{2}{*}{ مجموع المريعات } & \multirow{2}{*}{ مصدر الاختلاف } & \multirow{2}{*}{ المتغير } \\
\hline الدلالة & القيمة & & & & & \\
\hline$\ldots 1$ & rAr.lA & q. IVv.Ar & 1 & q. IVV.Ar & النوع ال & \multirow{5}{*}{ الأكاديمي التلكؤ } \\
\hline$\ldots 1$ & $r q . r r$ & $7 \wedge \leq \vee 9.7 \vee$ & 1 & $71 \leq \vee 9.7 \vee$ & التخصص & \\
\hline$\ldots 0$ & $0.0 \mathrm{r}$ & $1 r \cdot 0 . r \leq$ & 1 & $1 T \cdot 0 . r \leq$ & النوع×التخصص & \\
\hline-- & -- & $r r 0.90$ & $r \cdot r$ & $\leqslant q . \vee \wedge . \leqslant q$ & الخطأ & \\
\hline-- & -- & -- & ru & $r . q . \leqslant 1 . r r$ & مجموع & \\
\hline
\end{tabular}


يتضـح من جدول (YV) وجود فروق دالة إحصائيًا في التلكؤ الأكاديمي فوفقًا

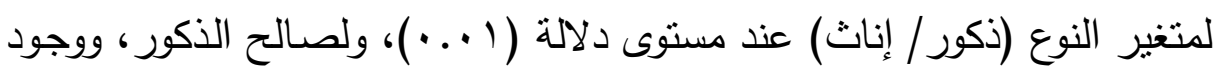

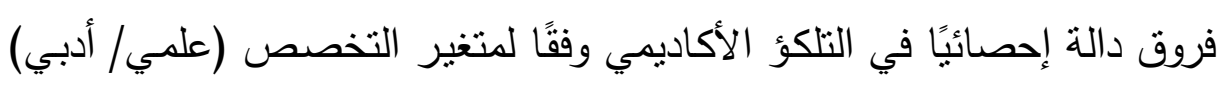

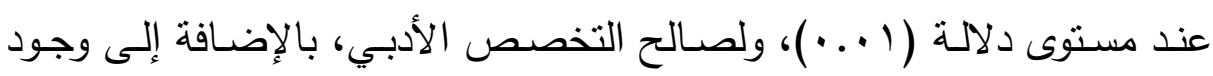

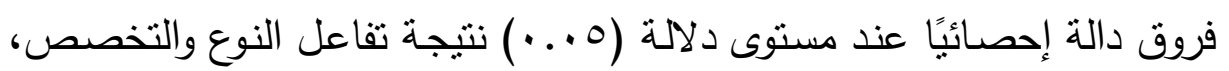
ولصالح إناث أدبي.

تتفق نتيجة البحث الحالي -من حيث وجود فروق دالة إحصائيًا في التلكؤ

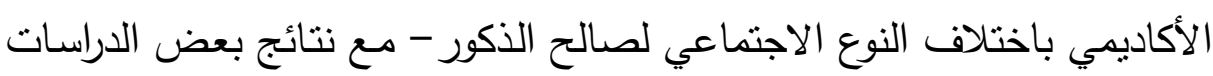

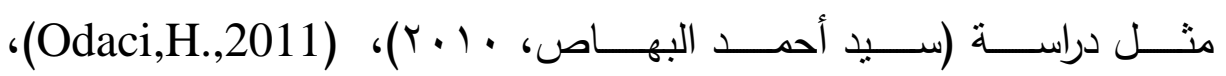

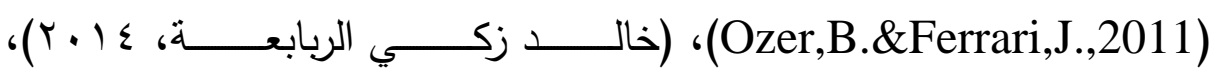

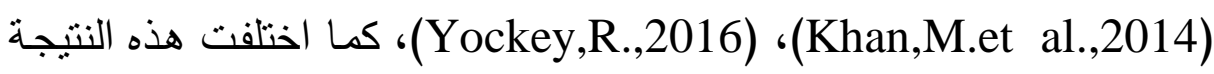

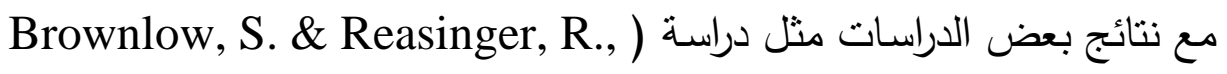

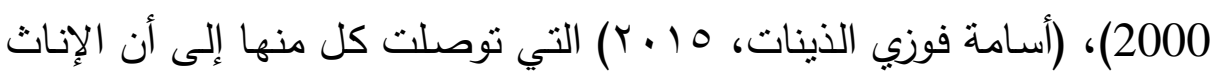
أكثر تلكوًُ من الذكور ، وكذللك اختلف مع بعض الدراسـات التي أوضحت كل هل

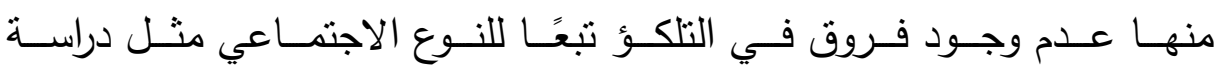

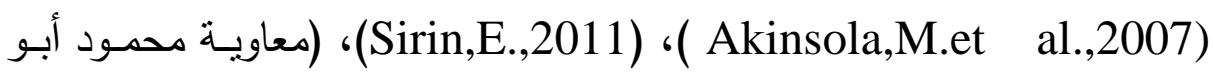

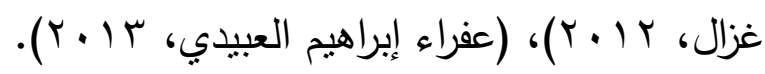
ويمكن أن نرجع وجود فروق دالة إحصائيًا في التلكؤ الأكاديمي بين الذئراء الذكور

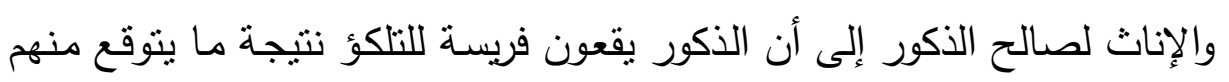

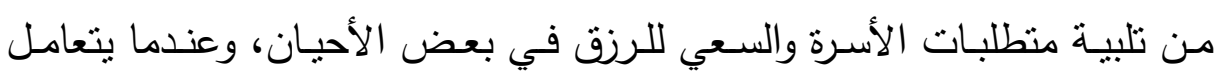

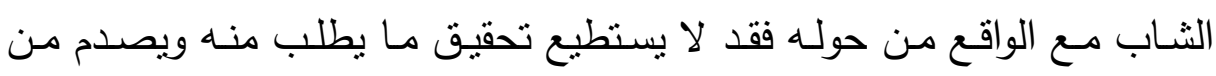

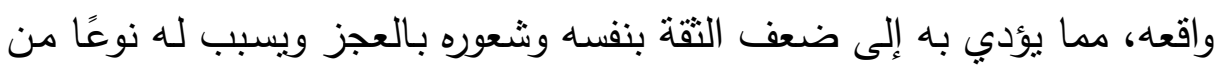
اللامبالاة.

كما يمكن أن نرجع ذلك إلى أن الذكور يقضون معظم أوقاتهم خارج المنزل

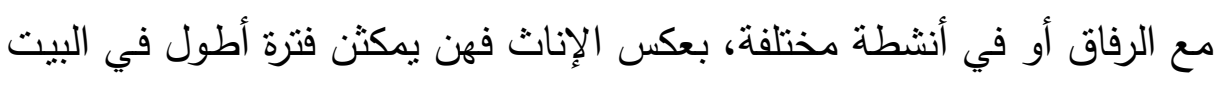


قد تساعدهن على الدراسة وإنجاز المهام، كما يمكن أن نرجع ذلك إلى أساليب

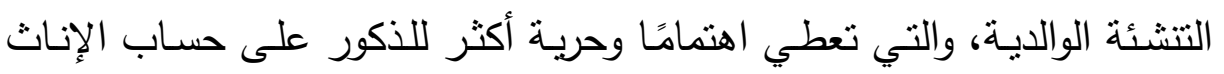

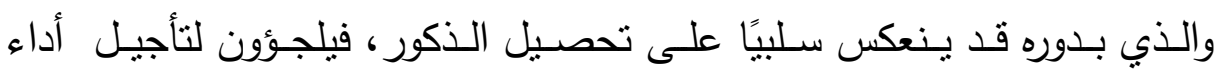

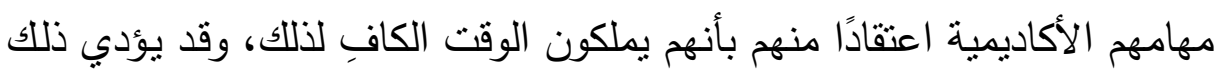

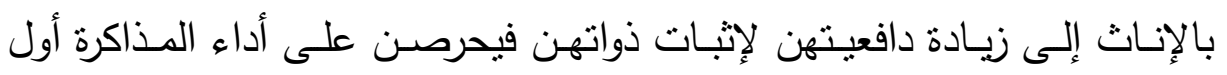
بأولٍٍ بالإنات وتتفق نتيجة البحث الحالي -من حيث وجود فروق دالة إحصائيًا في التلكؤ

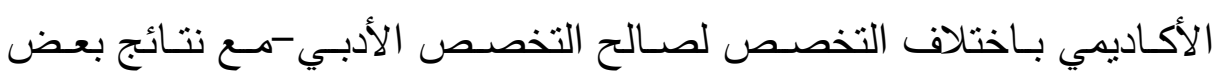

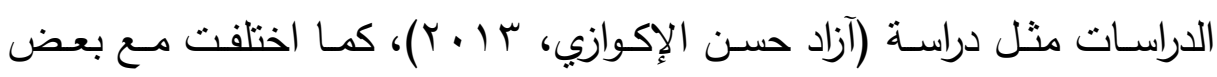

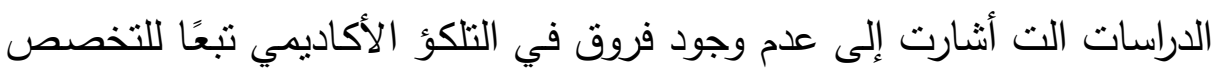

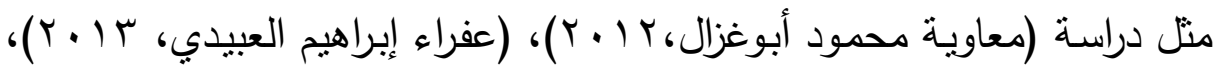
(ALQuadah,M. et al.,2014)، وكذلك تختلف مـع دراسـة (هيفاء جبار

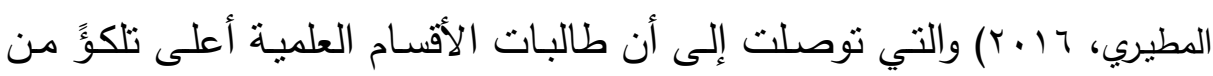
نظيرتهن في الثعب الأدبية. ويمكن أن نرجـع وجـود فـروق دالـة إحصـائيًا في التلكؤ الأكـاديمي بـين

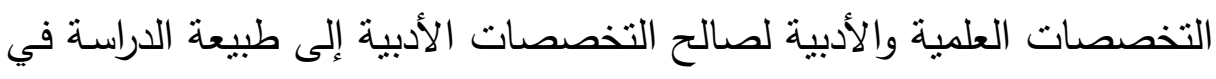

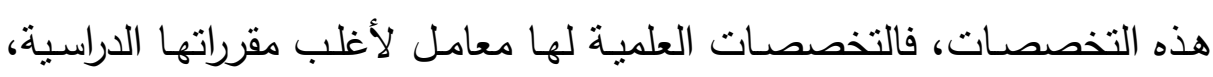

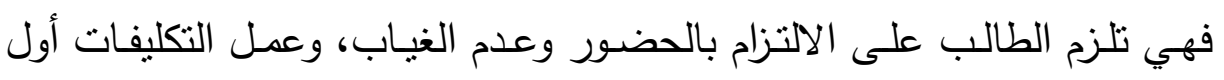

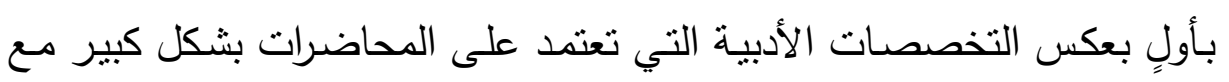

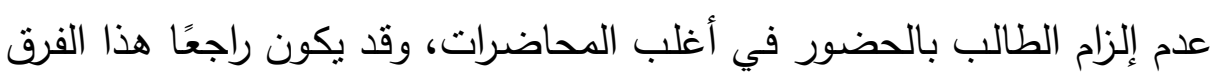
أيضًا لقلة أعداد الطلاب في الأقسام العلمية مقارنة بأعدادهم في الأقسام الأدبية،

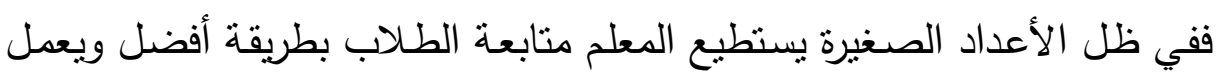
على حثهم للمذاكرة والمواظبة بصورة مستمرة. ويتضح مما سبق إنه نوجد فروق دالة إحصائيًا في التلكؤ الأكاديمي فوفقًا

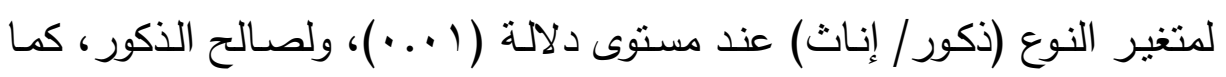


توجد فروق دالة إحصائًا في التلكؤ الأكاديمي وفقًا لمتغير التخصص (علمي/ التصال

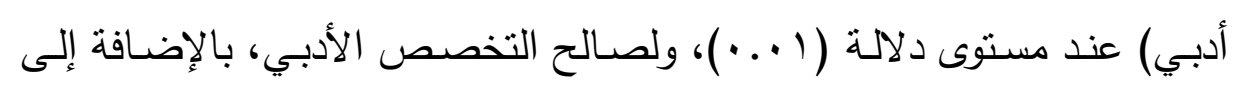

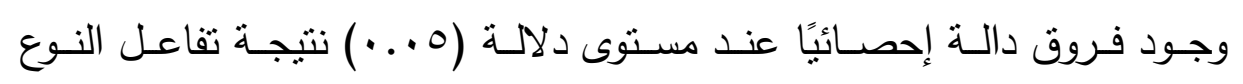

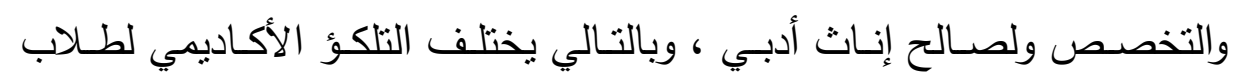

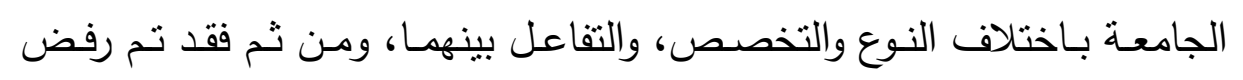
الفرض السادس وقبول الفرض البديل. نتائج الفرض السابع ومناقشته ينص الفرض السابع على أنه " توجد فروق ذات دلالة إحصائية بين منوسطات

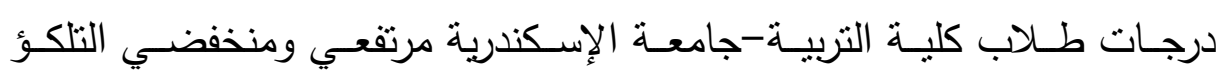
الأكاديمي في عادات العقل". ولاختبار هذا الفرض قام الباحث بإجراء اختبار "ت" للمجموعات المستقلة، وذلك لحساب الفروق بين متوسطات درجات الطلاب مرتفعي ومنخفضي التلكؤ الأكاديمي في عادات العقل، وقد تم تصنيف الطلاب مرتفعي ومنخفضي التلكؤ منوسي

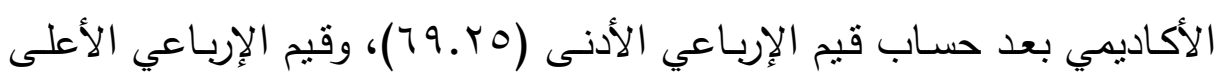

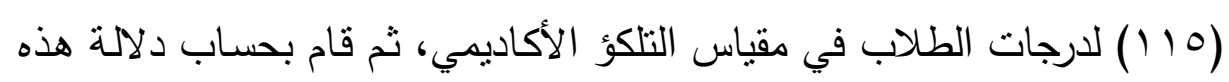

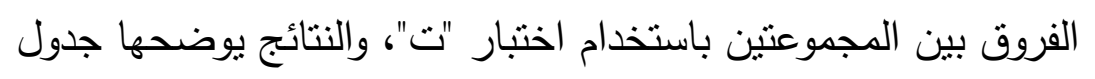


جدول (r ( المتوسطات الحسابية والانحرافات المعيارية وقيم "ت" لارجات الطلاب مرتفعي ومنخفضي التلكؤ الأكاديمي في عادات العقل

\begin{tabular}{|c|c|c|c|c|c|c|}
\hline & 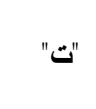 & الأكاديمي & 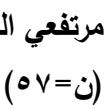 & ك. الأكاديمي & منخفضي (ن ه •) & المحور \\
\hline الدلالة & القيمة & الانحراف & المتوسط & الانحراف & المتوسط & \\
\hline$\ldots 1$ & 7.99 & r.Yo & $1 . .11$ & $1 . \wedge r$ & Ir.AT & المثابرة \\
\hline$\cdots 1$ & 0.44 & 1.174 & $9 . r 9$ & T.rV & 11.87 & التفكير في التفكير \\
\hline$\cdots 1$ & $7 . r \wedge$ & Y. $\{\varepsilon$ & $1 . .11$ & r... & $1 Y . \wedge 9$ & التساؤل وطرح الأسئلة \\
\hline$\ldots 1$ & 0.19 & r.T1 & 9.91 & $T . \leqslant Y$ & 19.79 & التفكير التبادلي \\
\hline$\cdots 1$ & 0.10 & r.५. & $9 . \wedge \leq$ & $r . . r$ & $1 T .1 T$ & السعي من أجل الدقة \\
\hline$\cdots 1$ & $\wedge .19$ & ^.v. & $\leqslant 9 . \leqslant r$ & V.rv & Tr... & مجموع عادات العقل \\
\hline
\end{tabular}

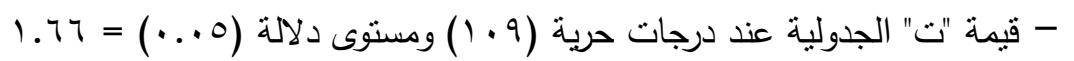

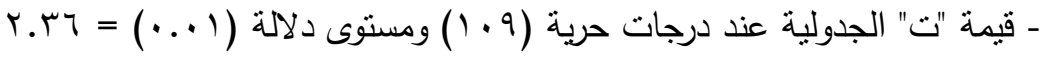

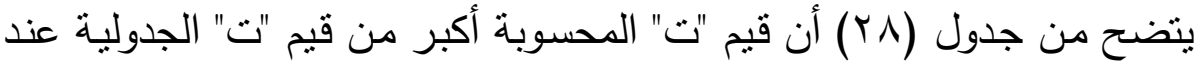

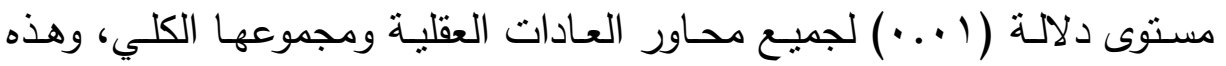
الفروق لصالح منخفضي التلكؤ الأكاديمي، مما يشير إلى أن منخفضي التلكؤ

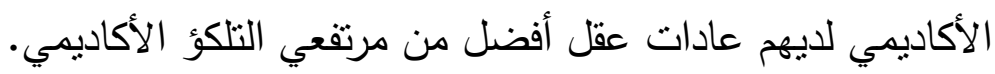

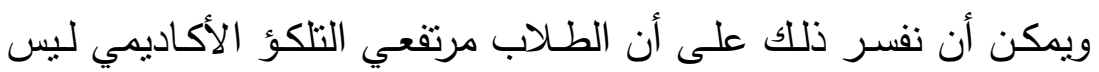
لديهم القدرة على المثابرة وطرح الأسئلة، ويفتقدون القدرة على العمل التعاوني

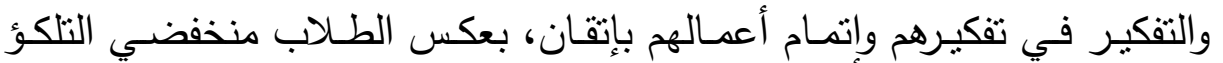
الأكاديمي فهم لديهم القدرة على مواصلة أداء المهام والسعي لإتمام مهامهم بدقة واتقان عن طريق التمعن في تفكيرهم والاستقسارات للذات وللآخرين، كما لديهخ لهره القدرة على العمل والتفكير التعاوني، ففي دراسـة (AL Attiyah,A.,2011)

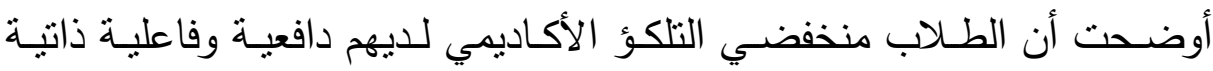
أعلى من الطلاب مرتفعي التلكؤ الأكاديمي، فهي إثـارة للتأثنر السلبي للتلكؤ الأكاديمي على دافعية الطلاب ومثابرتهم في حل المشكلات. 


\section{نتائج الفرض الثامن ومناقشته}

ينص الفرض الثامن على أنه: "توجد فروق ذات دلالة إحصائية بين متوسطات

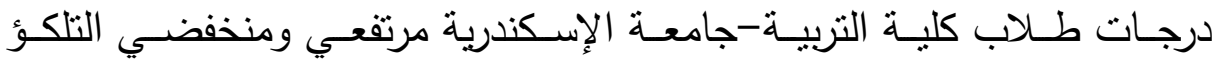

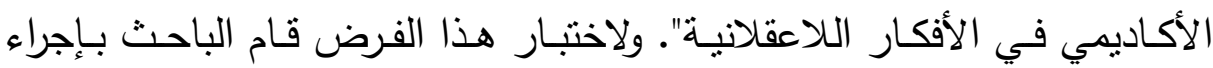
اختبار "ت" للمجموعات المستقلة، وذلك لحساب الفروق بين متوسطات درجات الطلاب مرتفعي ومنخفضي التلكؤ الأكاديمي في مقياس الأفكار اللاعقلانية، وقد

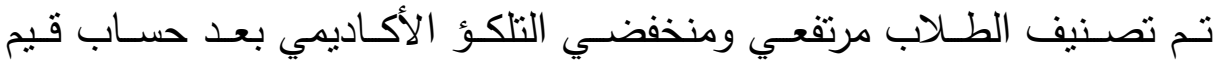

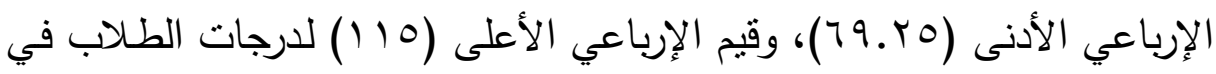

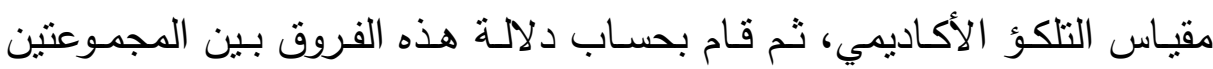

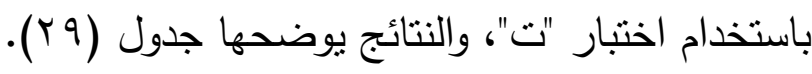

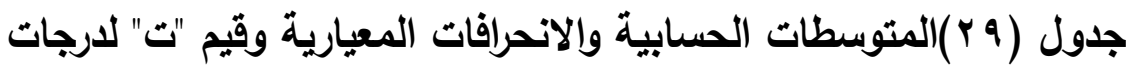
الطلاب مرتفعي ومنخفضي التلكؤ الأكاديمي في عادات العقل

\begin{tabular}{|c|c|c|c|c|c|c|}
\hline \multicolumn{2}{|c|}{ 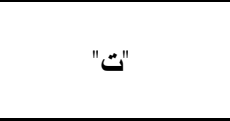 } & \multicolumn{2}{|c|}{$\begin{array}{c}\text { مرتفعي التلكؤ الأكاديمي } \\
\text { (ن })\end{array}$} & \multicolumn{2}{|c|}{ 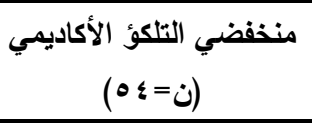 } & \multirow[t]{2}{*}{ المحور } \\
\hline الدلالة & القيمة & الانحراف & المتوسط & الانحراف & المتوسط & \\
\hline$\cdots 1$ & $V . \cdot \varepsilon$ & r.r^ & Ir.sV & r.IV & $1 \cdot 0$. & طلب الاستحسان \\
\hline$\ldots 1$ & 0.91 & r.lı & Ir.rY & r... & $1 . . A v$ & الاعتمادية \\
\hline$\cdots 1$ & O.rV & Y.OY & Ir.vo & $1 . \wedge \varepsilon$ & $1 \cdot .0 \leq$ & الجدية \\
\hline$\ldots 1$ & $\leq .19$ & r.ro & IY. & Y.।A & $1 . .70$ & علاقة الرجل بالمرأة \\
\hline$\cdots 1$ & r.ry & r.19 & $1 Y . .0$ & r.rq & $1.7 v$ & تجنب المشكلات \\
\hline$\cdots 1$ & $\varepsilon .0 \mathrm{~V}$ & r.ro & Ir... & $1 . v_{1}$ & $1 . . r q$ & التهور الانفعالي \\
\hline$\cdots 1$ & r.०q & 1.97 & $11 . v r$ & $1 . \wedge r$ & $1 \cdot \ldots r$ & دور الحظ في الحياة \\
\hline$\cdots \cdot 1$ & $7.1 r$ & $11 . v \leq 0$ & $\Lambda V . V r$ & $1 r \ldots r$ & Vr.qI & مجموع الأفكار اللاعقلانية \\
\hline
\end{tabular}

- قيمة "ت" الجدولية عند درجات حرية (9 • (1) ومستوى دلالة (0. .. ) = 17.

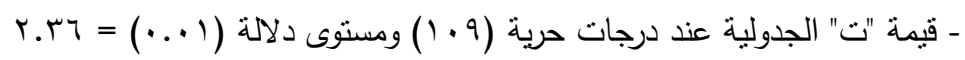

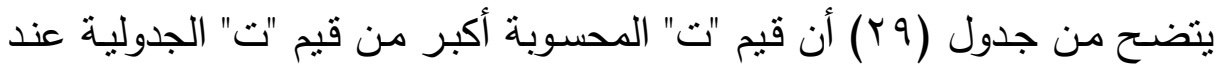
مستوى دلالة (1 ...) لجميع محاور الأفكار اللاعقلانية ومجموعها الكلي، وهذه 
الفروق لصـالح مرتفعي التلكؤ الأكـاديمي، ممـا يُشـير إلى أن مرتفعي التلكؤ الأكاديمي لديهم الأفكار اللاعقلانية أعلى من منخفضي الادي التلكؤ الأكاديمي.

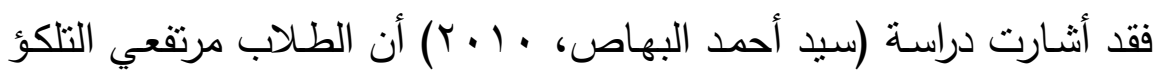

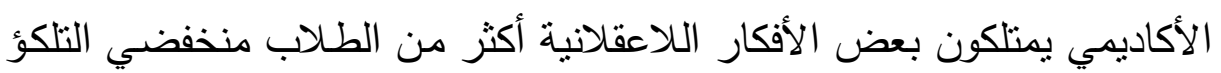

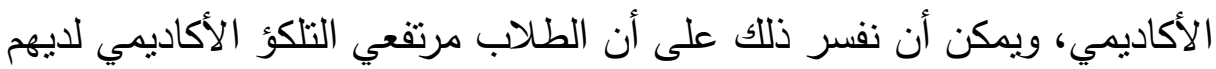
بعض الأفكار الخاطئة حول بعض النقاط مثل: المبالغة في أهمية دور ومكانة الرجل، ولابد وأن يتسم بالفرد بالرسمية والجدية كي يُحترم من الآخرين، فهم أكثر بهر اعتمادًا على الآخرين ويبتعدون عن المشكلات دون العمل على حلها، ويعطون بهن

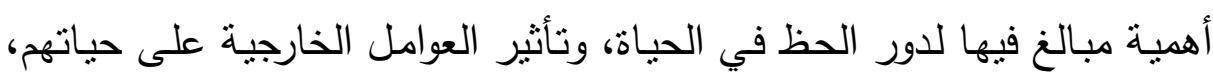

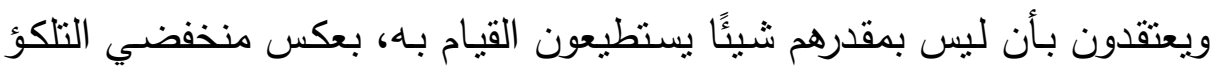
الأكاديمي فهو لديهم القدرة على مواجهة المشكلات والعمل على حلها، ويمتازون بالاستقلالية وأكثر ثبانًا إنفعاليًا. نتائج الفرض التاسع ومناقشته ينص الفرض التاسع على أنه " يمكن التتبؤ بالتلكؤ الأكاديمي لدى طلاب كلية التربية-جامعة الإسكندرية بمعلومية عادات العقل لديهر". وللتحقق من صحة هذا الفرض استخدم الباحث تحليل الانحدار المتعدد، ويوضح جدول (· ب) تحليل تباين الانحدار وقيمة "ف" ودلالتها الإحصائية.

\begin{tabular}{|c|c|c|c|c|c|}
\hline 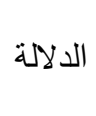 & "فيــــــــة & منتسط المربعات & درجـــــات & مجموع المربعات & مصدر الاختلاف \\
\hline \multirow{3}{*}{$\cdots 1$} & \multirow{3}{*}{91.09} & $\left.\sum q V . r\right)$ & 0 & $r \leq \wedge \neg . \cdot r$ & الانحدار \\
\hline & & $0 . . \varepsilon$ & $r \cdot T$ & $1 . r \wedge . \wedge 0$ & البواقي \\
\hline & & -- & YI & roY $\varepsilon . \wedge \Lambda$ & 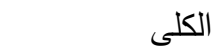 \\
\hline
\end{tabular}

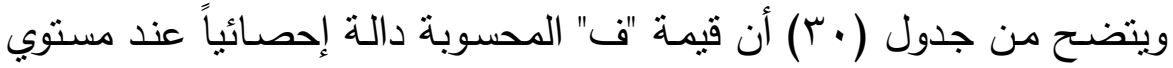
دلالة ( (...) مما يدل على أن المتغيرات المستقلة (عادات العقل)، تؤثر بدرجة 
دالـة إحصـائياً في تحديد التلكؤ الأكاديمي، ومن ثم توجد علاقـة إنحداريـة بين المتغيرات المستقلة (عادات العقل)، والمتغير التابع (التلكؤ الأكاديمي)، ويوضـح جدول (اب) ملخص تحليل الانحدار المتعدد.

جدول (اب) ملخص تحليل الانحدار المتعدد

\begin{tabular}{|c|c|c|c|c|c|c|}
\hline الالالة & قيمة "ت" & معامل الانحدار المعياري & الخطأ المعياري & معامل الانحدار & & \\
\hline$\ldots 1$ & I. Y. . . & -- & $r . .7$ & $r) . \Lambda$. & \multicolumn{2}{|c|}{ الثابت Constant } \\
\hline$\ldots 1$ & 1.70 & ..Vr.- &..$\leqslant r$. & $.9 \leq .-$ & المثابرة & 1 \\
\hline$\ldots 1$ & Y.Y^ & $.17 .-$ &. .271 & $. \vee \wedge \vee-$ & التفكير في التفكير & r \\
\hline$\ldots 1$ & r.l1 & $. \varepsilon \mid r-$ &.$\leqslant 1 r$ & $. \wedge r \wedge-$ & التساؤل وطرح الأسئلة & $r$ \\
\hline$\ldots 1$ & r.rr & - & מrr. & $. v \circ V-$ & التفكير التبادلي & $\varepsilon$ \\
\hline$\ldots 1$ & 9.01 & $. r q \cdot-$ & quq & $.9 r \leq-$ & السعي من أجل الدقة & 0 \\
\hline
\end{tabular}

- قيمة "ت" الجدولية عند مستوى دلالة (0. . . • 1.

- قيمة "ت" الجدولية عند مستوى دلالة (1 . . •) =9.

يتضح من جدول (1) أن قيم "ت" لمعامات الانحدار دالة إحصائياً عند مسـتوى دلالـة إحصـائية ( ( . • )، ومـن ثم يُمكن التبـؤ بـالتلكؤ الأكاديمي مـن خلال عادات العقل، ويمكن صياغة معادلة الانحدار المتعدد التي تعين التببؤ بالتلكؤ الأكاديمي علي النحو التالي:

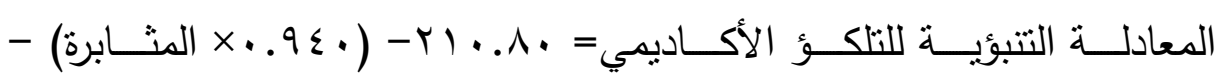

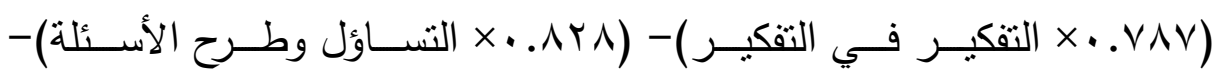
( × . vov) أو يمكن صياغتها كالتالي:

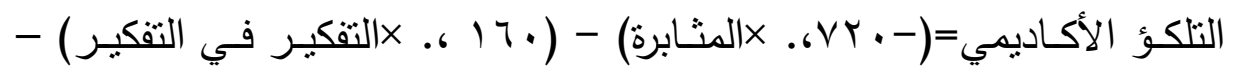

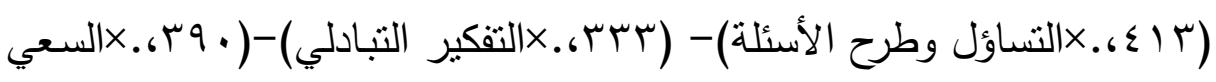
من أجل الاقة).

وقد قام الباحث بحساب قيم معامالت الارتباط بين كل متغير من المتغيرات المستقلة والمتغير التابع، وقيم معاملات الارتباط الجزئي والتي تشير إلى مقدار $1 \cdot 1$ 
العلاقة بين كل متغير تابع والمتغير المستقل في حالة عزل جزء من العوامل المؤثرة فى الارتبـاط الكلى، ونسب المسـاهمة للمتغيرات المستقلة في المتغير

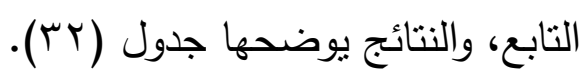

جدول (rT) 9 (r معامل الارتباط المتعدد ومريع معامل الارتباط المتعدد والخطأ المعياري للقياس ونسب المساهمة للمتغيرات المستقلة في المتغير التابع للنموذج المستخلص من تحليل الانحدار

\begin{tabular}{|c|c|c|c|c|}
\hline نسبة المساهمة & المعباري & مربع معامل الارتباط & 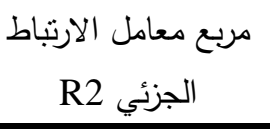 & 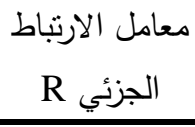 \\
\hline$\% \vee 1.9$. & V.l. & $\therefore \vee 19$ & . .VYT & . AOr \\
\hline
\end{tabular}

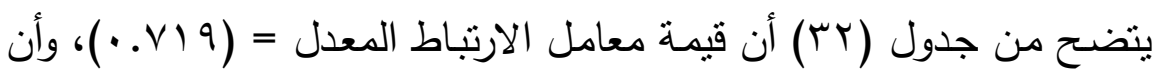
نسبة مساهمة المتغيرات المستقلة في تفسير المتغير التابع (التلكؤ الأكاديمي)

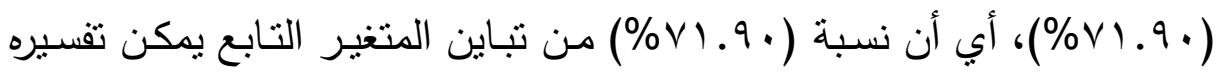
بمعلوميـة المتغيرات المستقلة (عادات العقل) بينمـا النسبة المتبقيـة من التباين ترجع إلى متغيرات أخري (البواقي) لم تؤخذ في الاعتبار في معادلة الانحدار .

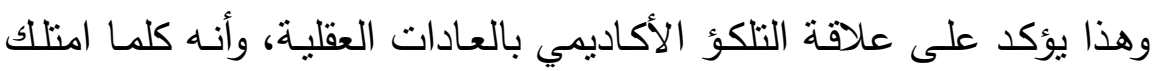

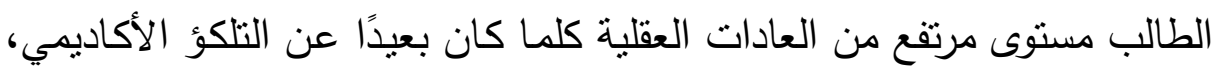
فالعادات العقلية لها تأثرها الإيجابي والفعال في تحسين الأداء الأكاديمي للطلاب

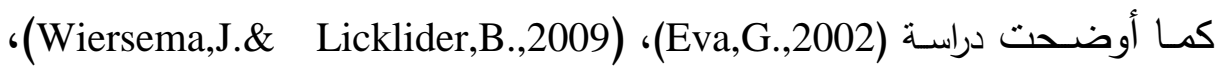

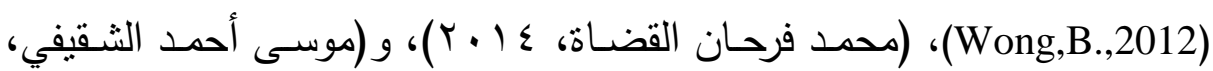
$\cdot(r \cdot 10$ مدـا سبق يتضـح أن عـادات العقل يمكن أن تتتبأ بـالتلكؤ الأكاديمي لدى طلاب كلية التربية-جامعة الإسكندرية، وعليه تم قبول الفرض التاسع. نتائج الفرض العاشر ومناقثته ينص الفرض التاسع على أنه " يمكن التتبؤ بالتلكؤ الأكاديمي للى طلاب كلية

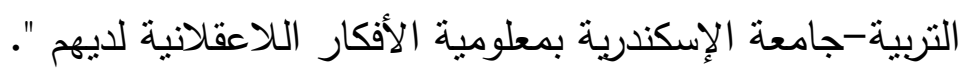


مجلة الاراسات التربوية والانسانية ـ كلية التربية ـ جامعة دمنهور . المجلد الثامن - العدد(ץ)- لسنة 1 ــץ

وللتحقق من صحة هذا الفرض استخدم الباحث تحليل الانحدار المتعدد، ويوضح جدول (rr) تحليل تباين الانحدار وقيمة "ف" ودلالتها الإحصائية. جـول (rr) قيمـة ف ودلالتهـا الإحصــائية لنمـوذج الانحـدار بـين المتغيـرات المستقلة

\begin{tabular}{|c|c|c|c|c|c|}
\hline الدلالة & قيمة "ق" & متوسط المربعات & درجية الحرية & مجموع المربعات & مصدر الاختلاف \\
\hline \multirow{3}{*}{$\ldots 1$} & \multirow{3}{*}{ IrI.Vq } & Y^৭.०. & v & Y.YT.OY & الانحدار \\
\hline & & r.ru & $r \cdot \varepsilon$ & 97..r. & البواقي \\
\hline & & -- & rul & rqAT.Ar & الكلى \\
\hline
\end{tabular}

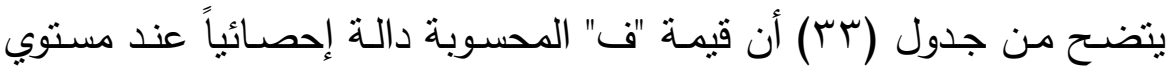

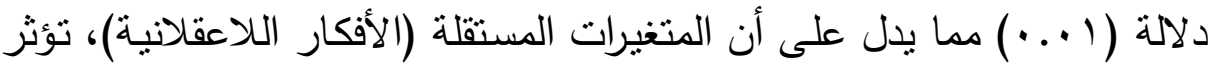
بدرجة دالة إحصائياً فى تحديد التلكؤ الأكاديمي ، ومن ثم توجد علاقة انحدارية

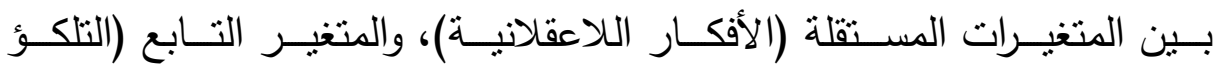
الأكاديمي)، ويوضح جدول (ع) ملخص تحليل الانحدار المتعدد. 


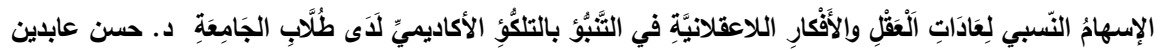

جدول (ع r) ملخص تعليل الانحدار المتعدد (ن=r +r)

\begin{tabular}{|c|c|c|c|c|c|c|}
\hline الدلالة - م الد & قيمة "ت" & معامل الانحدار المعياري & الخطأ المعياري & معامل الانحدار & 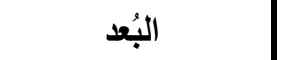 & م \\
\hline$\ldots 1$ & IV.TV & -- & $1 . \leqslant \pi$ & ro.r. & \multicolumn{2}{|l|}{ Constant الثابت } \\
\hline$\ldots 1$ & ז. ^ & . . $\{r$. &. .701 & $\{. .9$ & طلب الاستحسان & 1 \\
\hline$\ldots 1$ & r.A1 &. .171 &. .794 & \&.V 9 & الاعتمادية & $r$ \\
\hline$\ldots 1$ & 纟.rq &. $.11 \%$ & . TVR & $1.1 \mathrm{~V}$ & الجدية & $r$ \\
\hline$\ldots 1$ & ד.VT &. $.1 \mathrm{rr}$ &.$r \circ 9$ & $1 . v \varepsilon$ & علاقة الرجل بالمرأة & $\varepsilon$ \\
\hline$\ldots 1$ & r.AI & . Trtr & $. r \leqslant r$ & .711 & تجنب المشكلات & 0 \\
\hline$\ldots 1$ & r.AT & .041 & . riso &..$v 01$ & التهور الانفعالي & 1 \\
\hline$\ldots 1$ & r.VA & ..VYY & . TAN & $\therefore$. VAV & دور الحظ في الحياة & $v$ \\
\hline
\end{tabular}

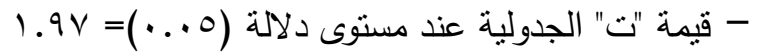

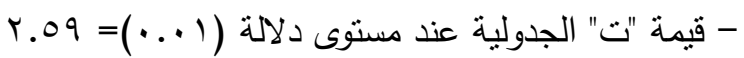

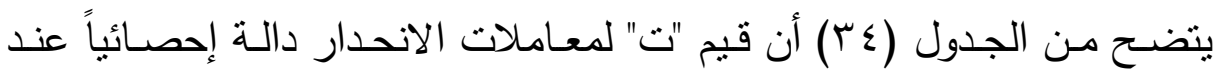

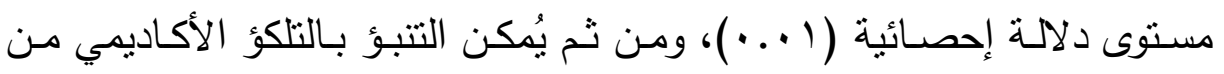
خلال الأفكار اللاعقلانية، ويمكن صياغة معادلة الانحدار المتعدد التي تعين على التنبؤ بالتلكؤ الأكاديمي علي النحو التالي:

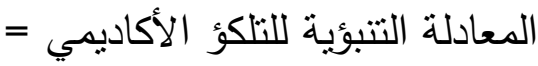

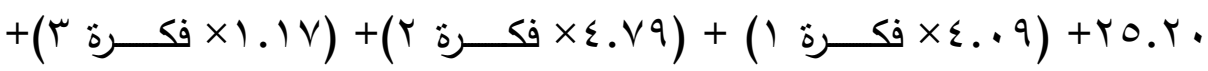

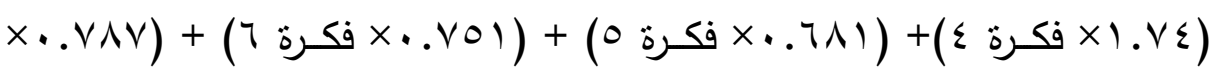
فكرة أو يمكن صياغتها كالتالي:

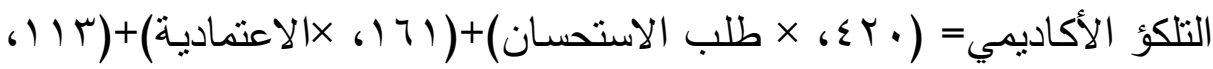

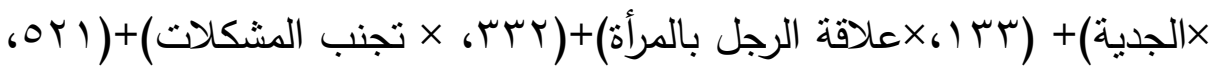

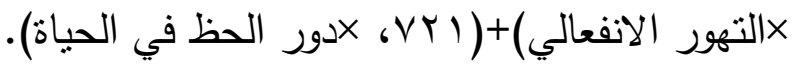
وقد قام الباحث بحسـاب قيم معاملات الارتباط بين كل متغير من المتغيرات المستقلة والمتغير التابع، وقيم معاملات الارتباط الجزئي والتي تشير إلى مقدار 
العلاقة بين كل متغير تابع والمتغير المستقل في حالة عزل جزء من العوامل المؤثرة فى الارتبـاط الكلى، ونسب المسـاهمة للمتغيرات المستقلة في المتغير

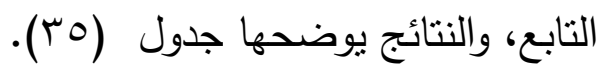

جدول (ro): معامل الارتباط المتعدد ومريع معامل الارتباط المتعدد وإلخطأ المعياري للقياس ونسب المساهمة للمتغيرات المستقلة في المتغير التابع للنموذج المستخلص من تحليل الانحدار

\begin{tabular}{|c|c|c|c|c|}
\hline نسلمساهمة & الخطأ المعياري & مريـع معامـل الارتبــاط & الجزئي معامـل الارتبـــاط & $\begin{array}{r}\text { الجزئي الارتياط } \\
\text { Reباط }\end{array}$ \\
\hline 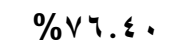 & T.Y & .V & $\therefore \vee 79$ & $\therefore \wedge \vee \vee$ \\
\hline
\end{tabular}

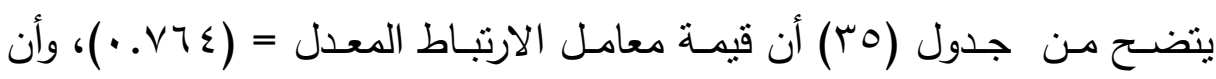
نسبة مساهمة المتغيرات المستقلة في تفسير المتغير التابع (التلكؤ الأكاديمي)

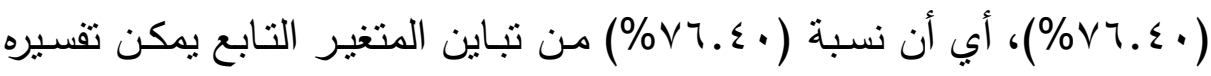

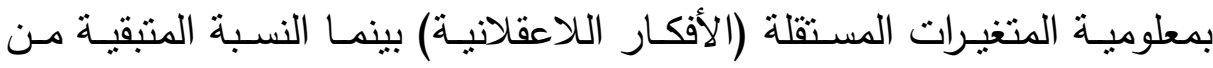

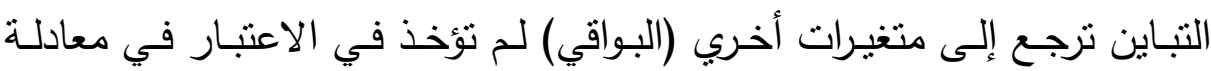
الانحدار .

وهذا يؤكد على علاقــة التلكؤ الأكـاديمي بالأفكـار اللاعقلانيـة وهـذا مـا

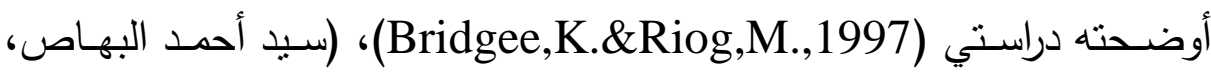

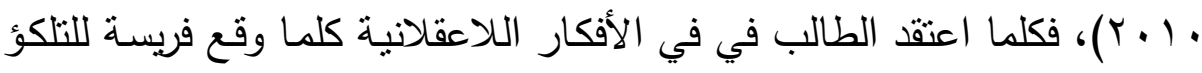

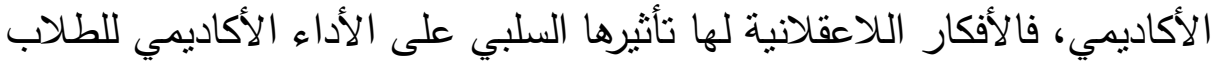

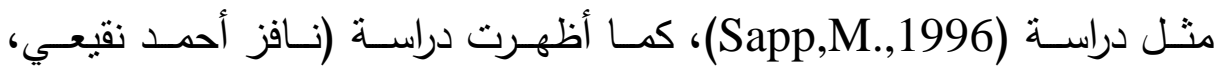

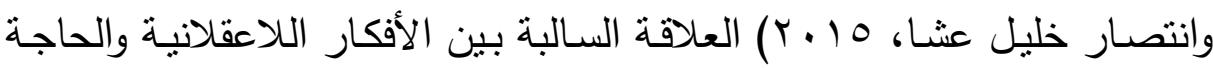
للمعرفي. مما سبق يتضح أن الأفكار اللاعقلانية يمكن أن تنتبأ بالتلكؤ الأكاديمي لدى

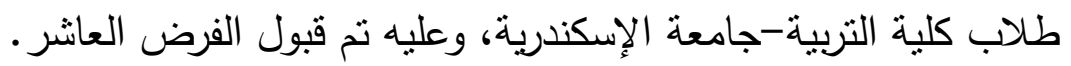




\section{توصيات البحث ومقترحاته}

في ضوء النتائج التي توصل إليها هذا البحث يمكن تقديم التوصيات التالية: 1- عقد دورات وندوات إرشادية للطلاب لتوعيتهم بخطورة التلكؤ الأكاديمي وآثاره السلبية على الفرد والمجتمع.

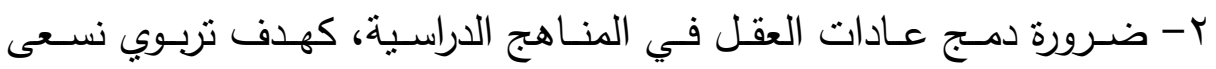
لتحقيقه. r- ضرورة تدريب أعضاء هيئة التدريس على أساليب التدريس الحديثة، والتي منها تتمية العادات العقلية للطلاب. ع - عقد دورات توعويـة للطـلاب حول خطورة الأفكار اللاعقلانيـة وتأثنيرهـا في تعابـ العملية التعليمية. ه- نمذجـة العلاقات السببية لعدد مـن المتغيرات على التلكؤ الأكاديمي لدى عينات تعليمية مختلفة. צ- فاعلية برنامج قائم على عادات العقل في التخفيف من التلكؤ الأكاديمي لدى طلاب الجامعة منخفضي التحصيل. 


\section{قائمة المراجع}

أولاً: مراجع عربية:

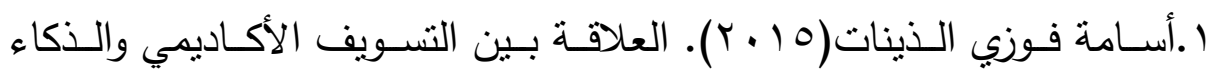
الانفعالي لاى طلبة جامعة اليرموك. رسالة ماجستير ، كلية التربية الإنية

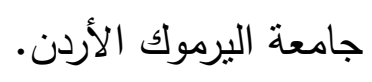

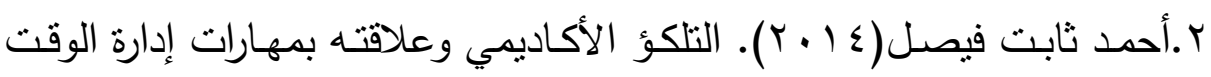

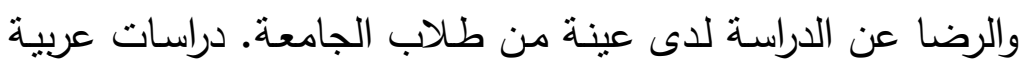

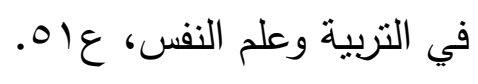

r. أزاد حسن الإكوازي (r (ץ). علاقة التلكؤ الأكـاديمي بعادات الاستخكار

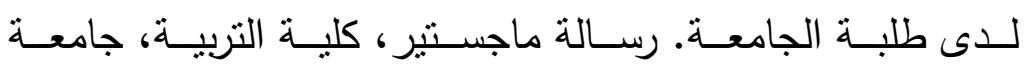

$$
\text { المستتصرية-العراق. }
$$

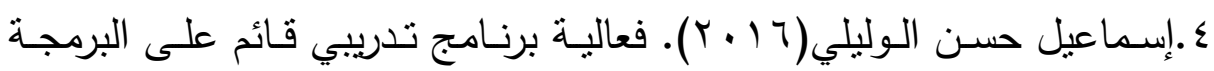
العصبية في تتمية الدافعية للإنجاز لاى طلاب الجامعة المتلكئين

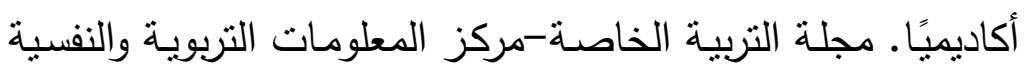

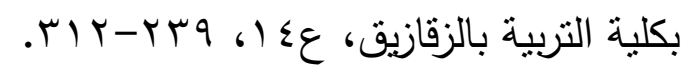

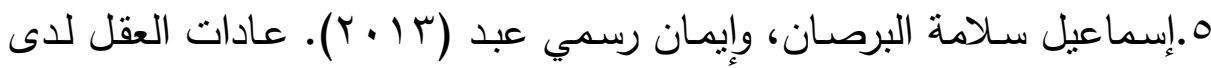

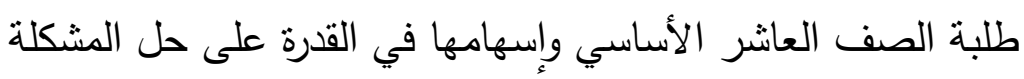

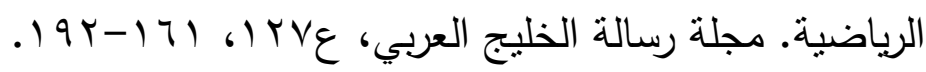

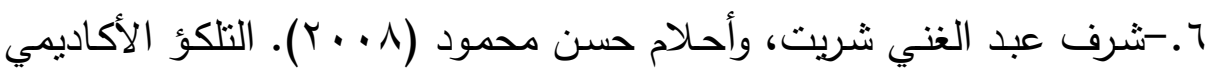

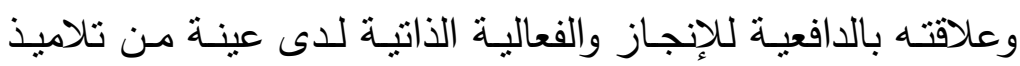

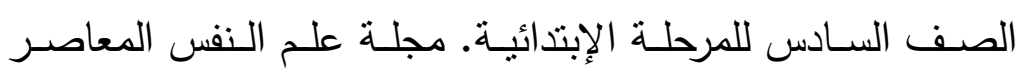

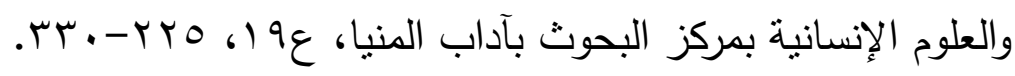

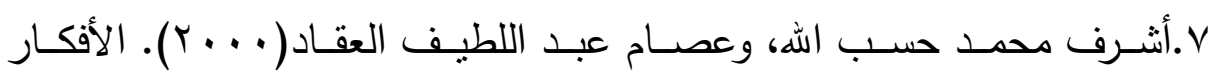

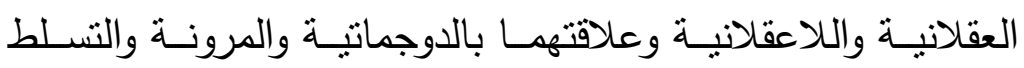


والـرفض الوالـدي لـدى شـباب جـامعتي الزقـازيق وجنـوب الـوادي.

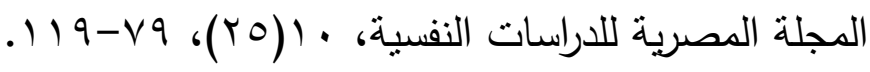

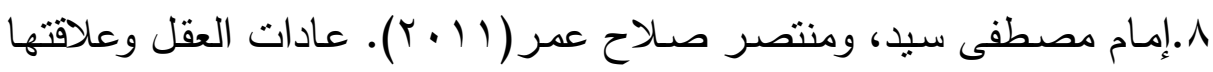

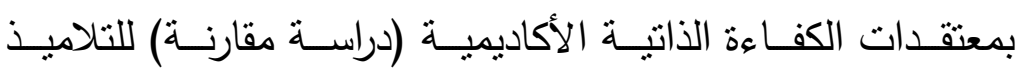

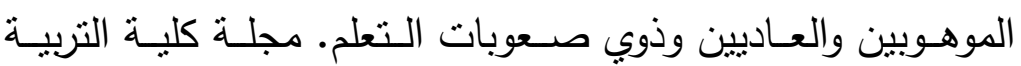

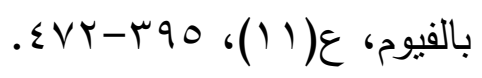

9.انتصار عبد الرحيم الدويكات (1991 ()). العلاقة بين مركز الضبط والأفكار العقلانية -اللاعقلانية ومدى تأثرهما ببعض المتغيرات الديموغرافية. رسالة ماجستير غير منشورة، جامعة اليرموك.

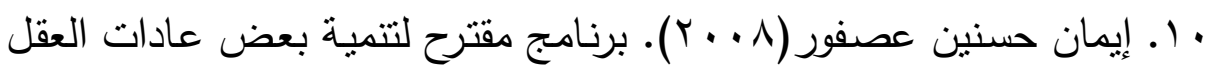

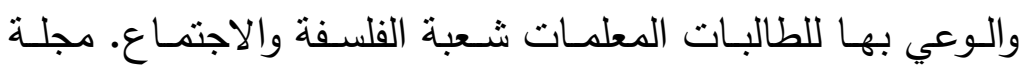

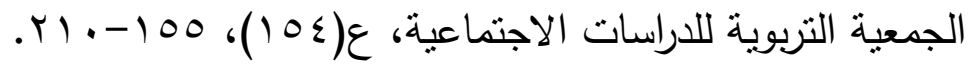

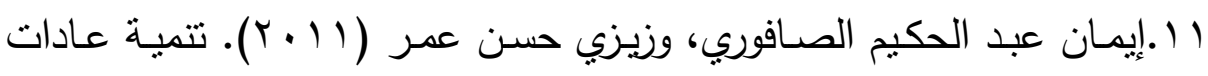

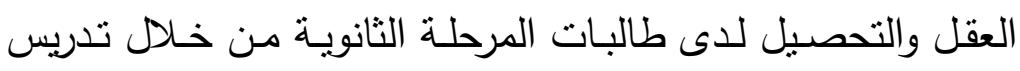

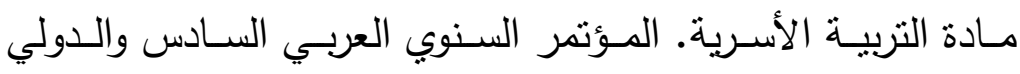
الثالث "تطوير بـرامج التعليم العـالي النوعي في مصـر والـوطن

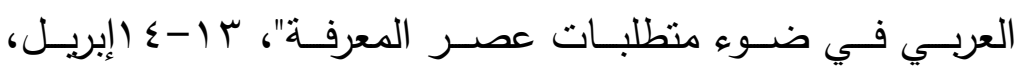

$$
.17 V T-17 \leq T
$$

r ا.بندر عبد الله الثريف (ع ا ـ Y). الفروق في التسويف الأكاديمي لدى طلاب

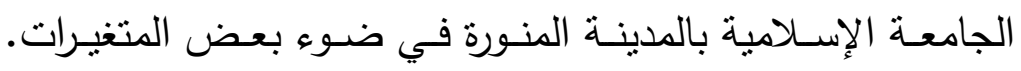

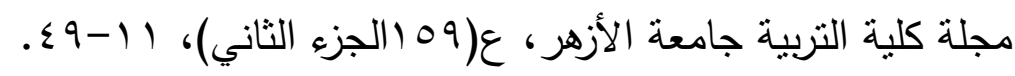

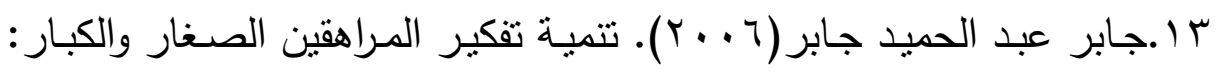
استراتيجيات للمدرسين. القاهرة: دار الفكر العربي. 
ع ا .حسن أحمد علام (^ . . r). محددات التسوبف الأكاديمي وعلاقتها ببعض المتغيرات النفسية الدراسية لدى عينة من طلاب الجامعة. المجلة

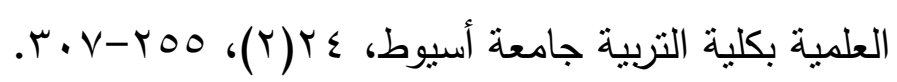
1 .حسن علي الزهراني(· ( • ( ). الأفكار اللاعقلانية وعلاقتها بإدارة الوقت لدى عينة من طلاب جامعة حائل. رسالة دكتوراه غير منشورة، جامعة

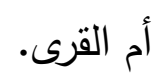

7 ا .حسن ناصر التميمي (Y ( ب). التلكؤ الأكاديمي وعلاقته بالضغوط النفسية

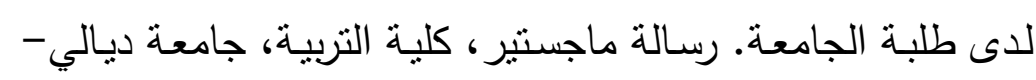

$$
\text { العراق. }
$$

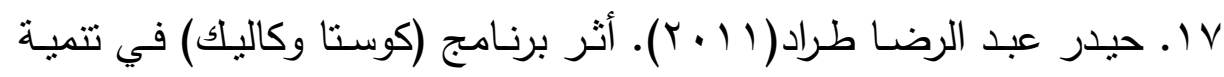
التفكير الإبداعي باستخدام عادات العقل لدى طلبة المرحلة الثالثة

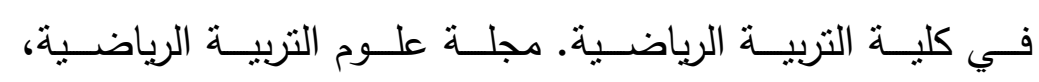

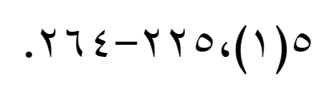

1 ا .خالـد الحميـدي العنـزي( • ( • ). إدراك القبـول -الـرفض الوالـدي والأفكـار اللاعقلانيـة وقلق المسـقبل لـى عينـة مـن طـلاب جامعـة الحـدود

$$
\text { الشمالية. رسالة ماجستير غير منشورة، جامعة أم القرى. }
$$

9 ا .خالد زكي الربابعة (ع ( ـ ب). التسويف الأكاديمي وعلاقته بالفاعليـة الذاتية

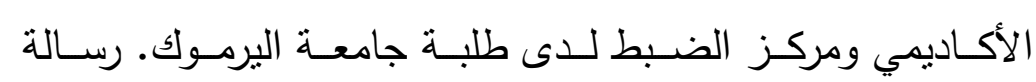
ماجستير غير منشورة، كلية التربية جامعة اليرموك الأردن. • . .داليا خيري عبد الوهـاب(0 1 ـ ب). الفروق بين مرتفعي ومنخفضسي التلكؤ الأكاديمي في التعلم ذاتي التتظيم والتحكم الذاتي لدى طلاب التربية

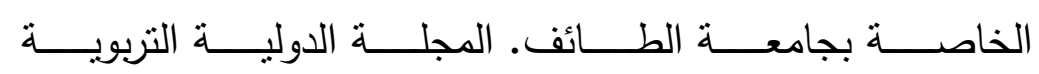

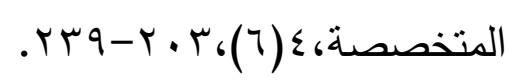




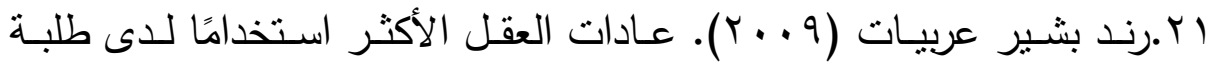

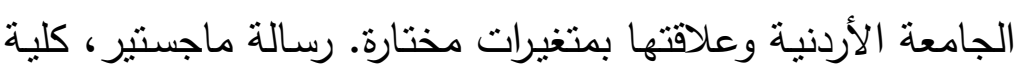
الدراسات العليا، الجامعة الأردنية.

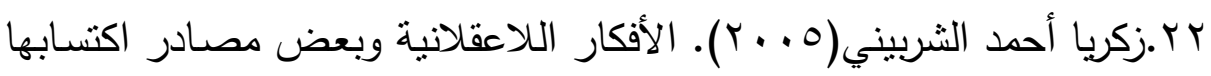

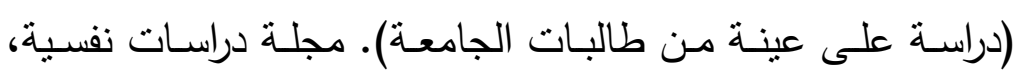

$$
\left..07 V-0)^{\prime}\right) ،(\varepsilon) 10
$$

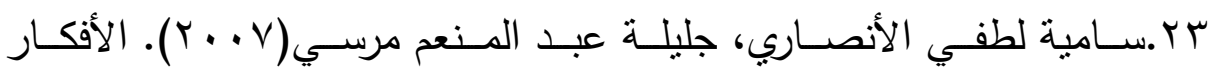

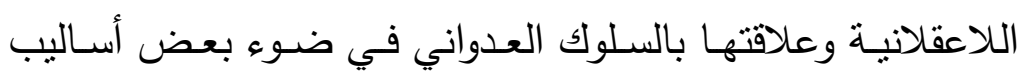

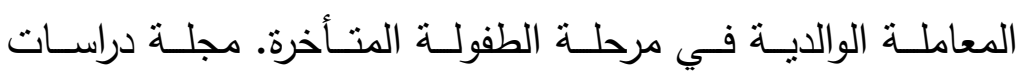

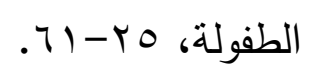

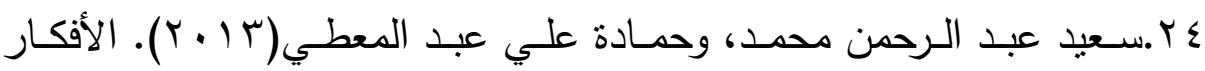

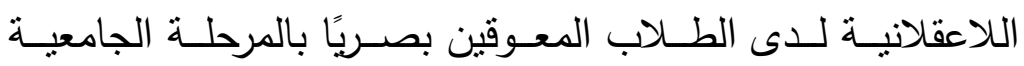

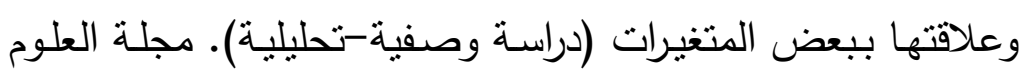

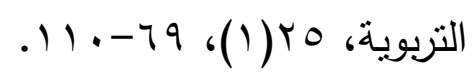

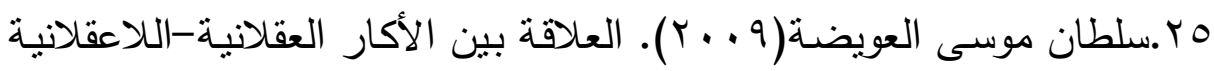

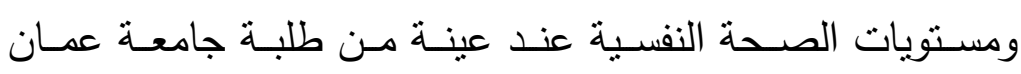

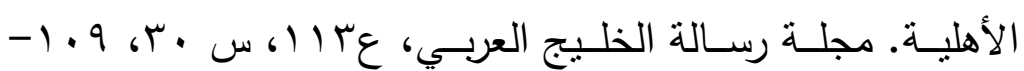

$$
.100
$$

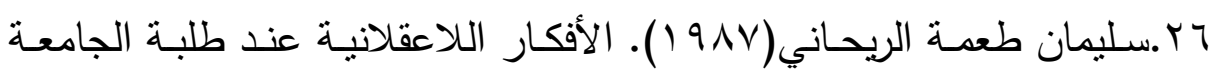

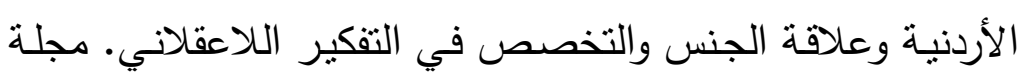

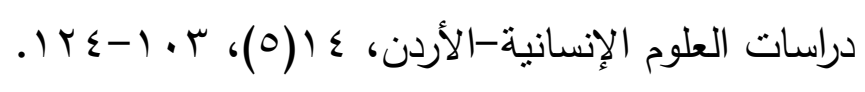

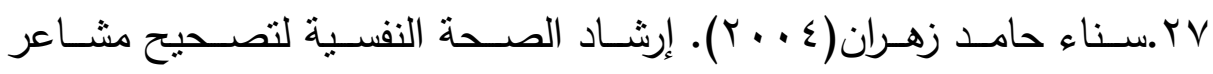

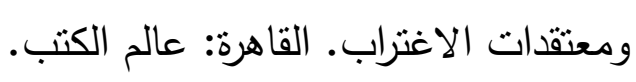




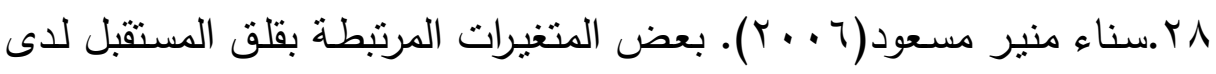
عينة من المراهقين "دراسة تشخيصية". رسالة دكتوراه غير منشورة، كلية التربية جامعة طنطا.

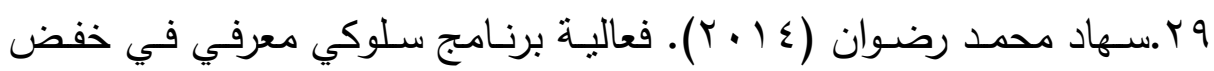

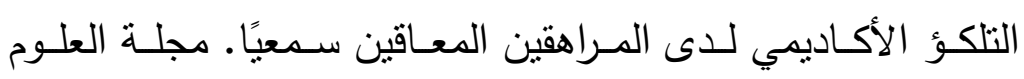

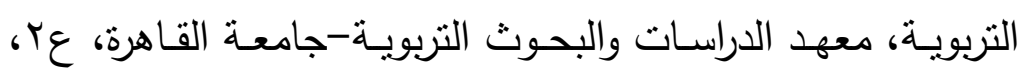

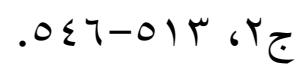

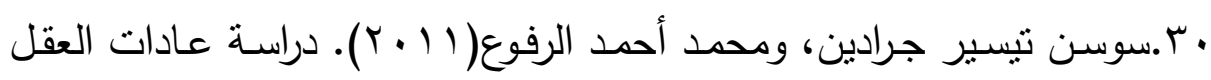
لدى طلبـة الجامعـة مـن حيث علاقتها بمتغيرات الخبرة الجامعيـة

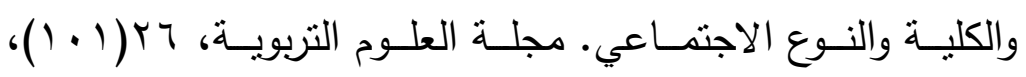

$$
\text { .rAV-rOl }
$$

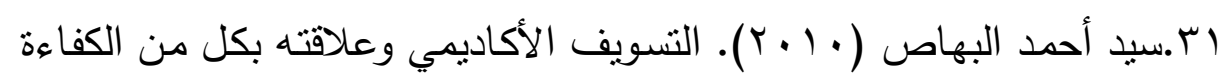

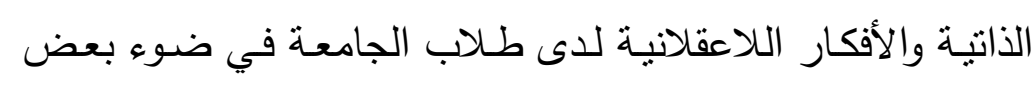

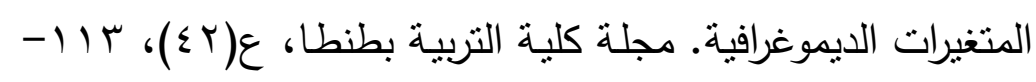
. 104

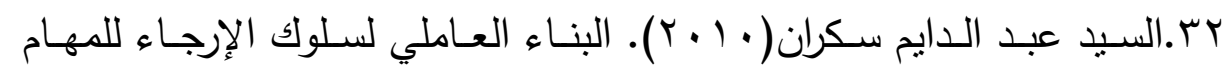

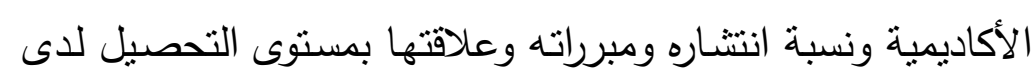
تلاميذ المرحلنين الثانوية والمتوسطة بمنطقة عسير بالمملكة العربية

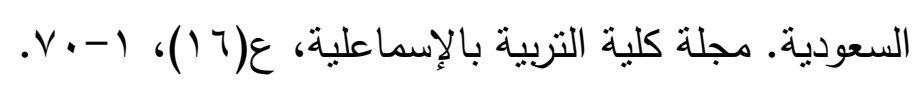

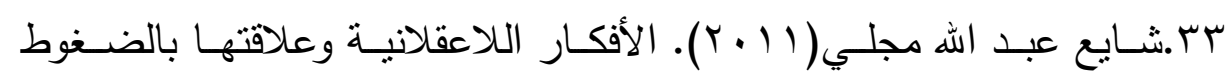

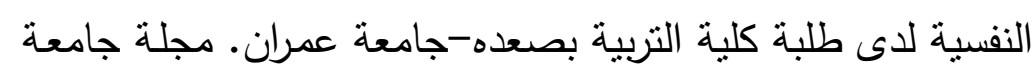

$$
\text { دمشق، م(YV)، }
$$

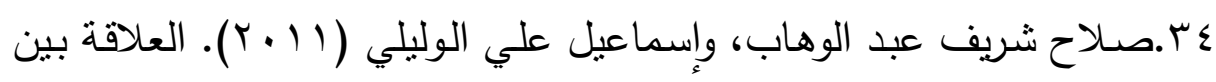

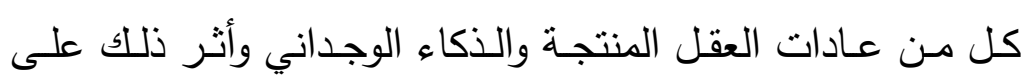


التحصيل الدراسي لدى طلاب المرحلة الثانوية من الجنسين. مجلة

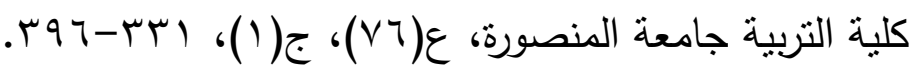

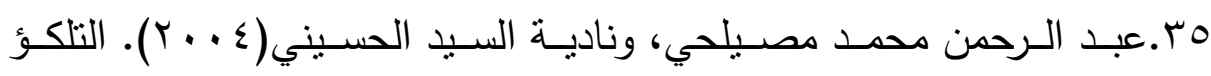

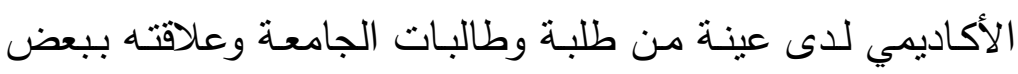

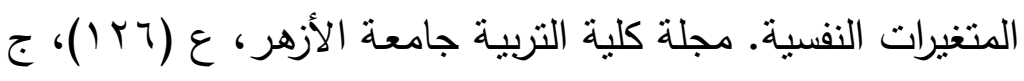

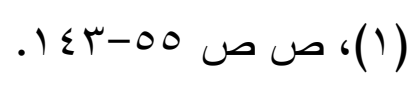

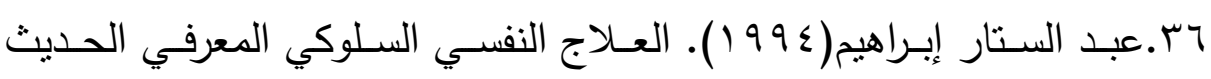
وأساليبه وميادينه وتطبيقه. القاهرة: دار الفجر للنشر والتوزيع.

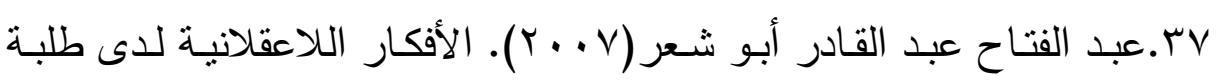
الجامعات الفلسطينية وعلاقتها ببعض المتغيرات. رسالة ماجستير غير منشورة، الجامعة الإسلامية.

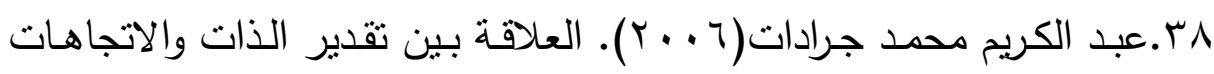

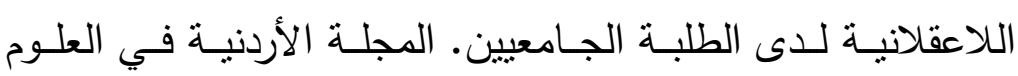

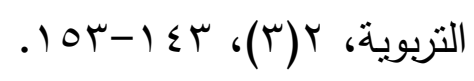

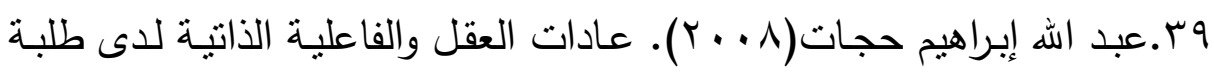

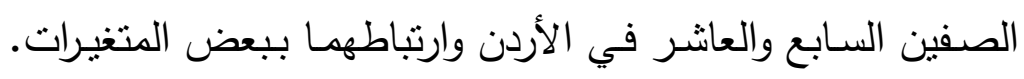

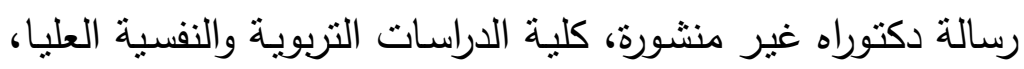
جامعة عمان العربية.

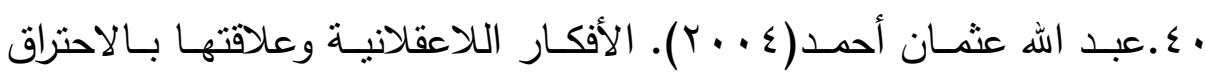

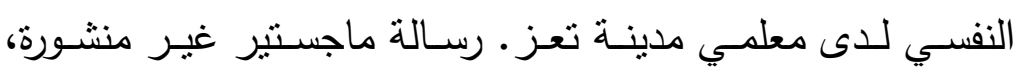
جامعة صنعاء.

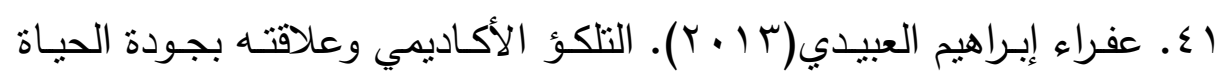

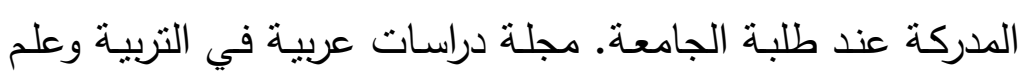

$$
\text { النفس، ع(0))، ج(1)، (1) }
$$




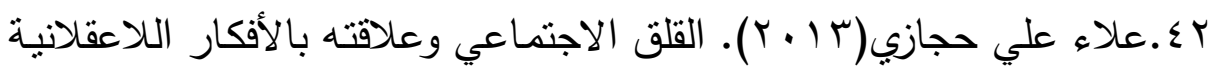

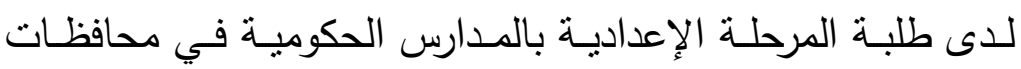
غزة. رسالة ماجستير غير منشورة، الجامعة الإسلامية غزة.

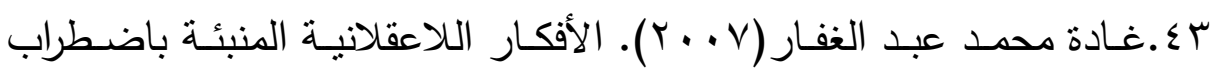

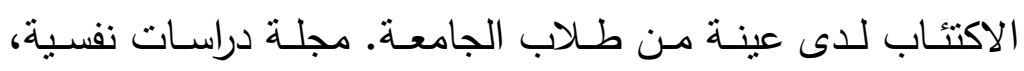

$$
\text { . }
$$

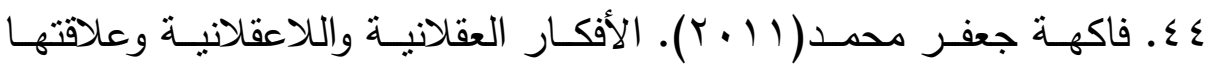
بالاكتئاب لدى طلبة كلية التربية-صبر -جامعة عدن. مجلة كلية

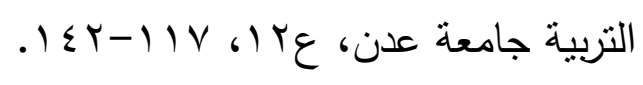

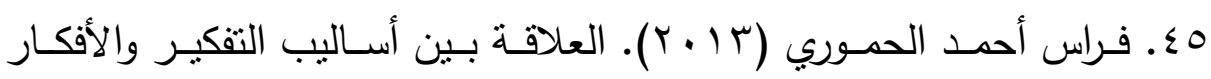

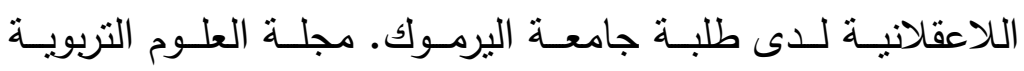

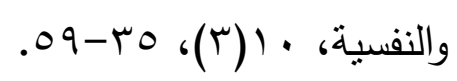

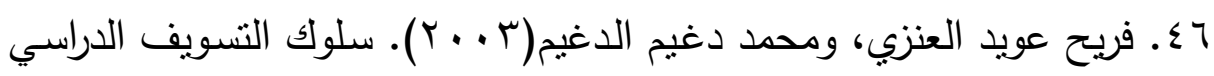

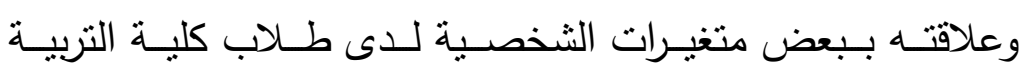

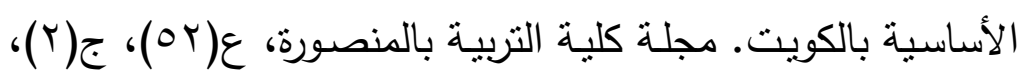

$$
.1 T V-1 \cdot r
$$

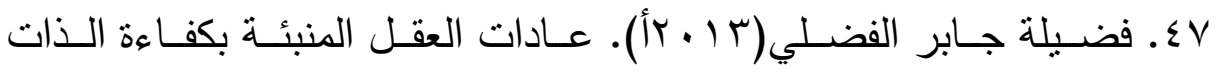

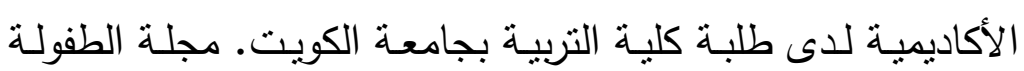

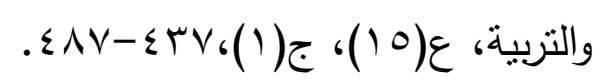

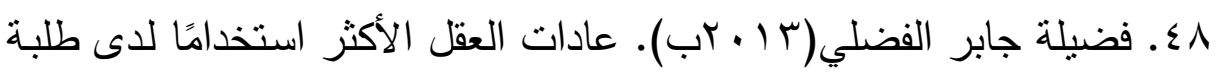
الصف الثاني عشر بدولة الكويت وعلاقتها بمتغيرات ديموغرافية.

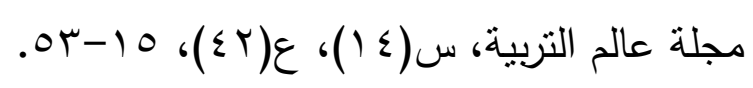

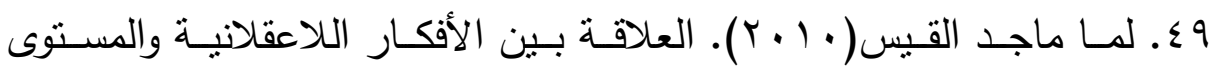
الدراسي والجنس وتقدير الذات لدى طلبـة جامعـة الطفيلة التقنيـة.

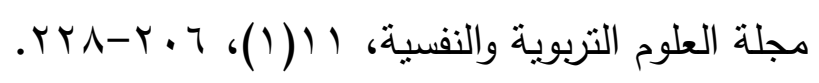


•. - لينة أحمد الجنادي، وابتسام محمود عمر (10 • ب). التسويف الأكاديمي

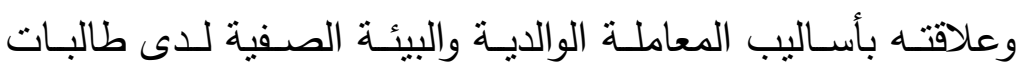

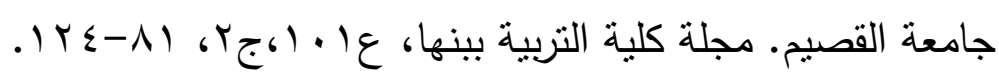

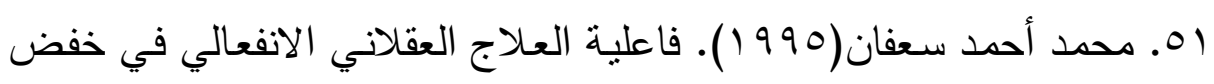
مستوى الثـعور بالذنب. مجلة كلية التربية بعين شمس، ع(9 (1)، (1)،

$$
\text { ج) }
$$

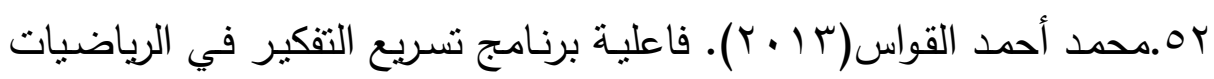

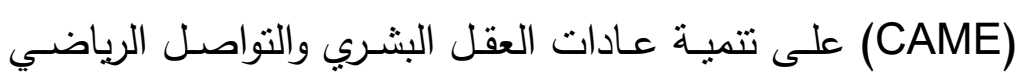

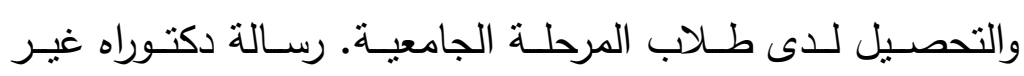

$$
\text { منشورة، جامعة أم القرى السعودية. }
$$

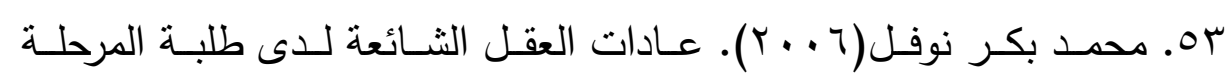

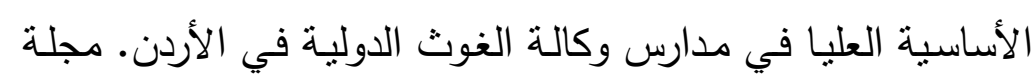

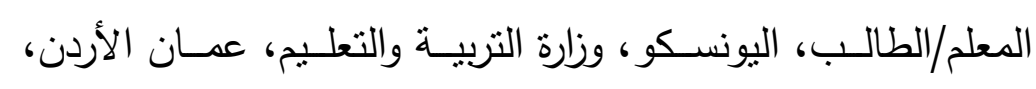

$$
\text { ع (1) }
$$

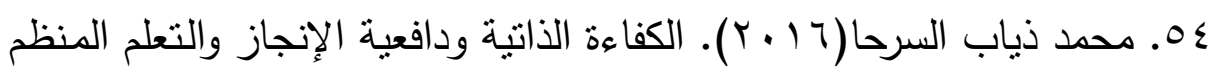

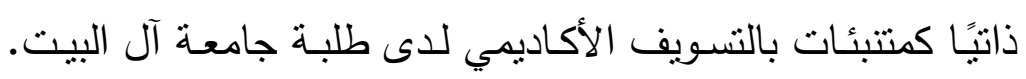
رسالة دكتوراه، كلية التربية جامعة اليرموك بالأردن.

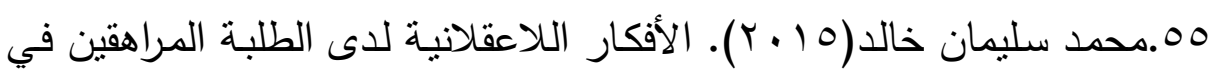

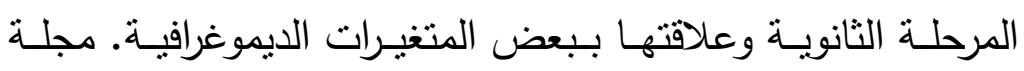

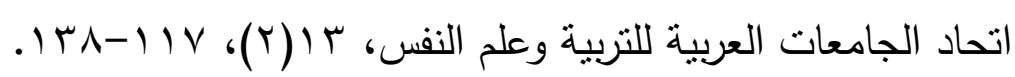

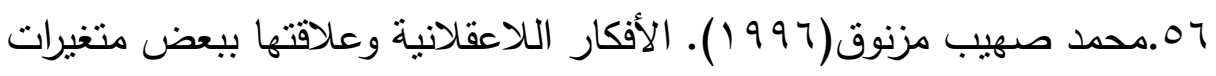

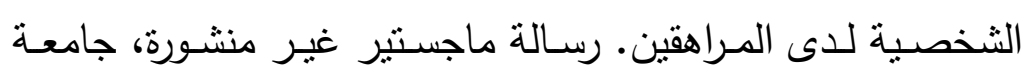
عين شمس. 


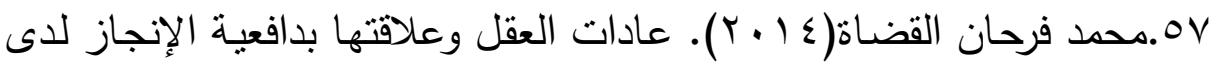

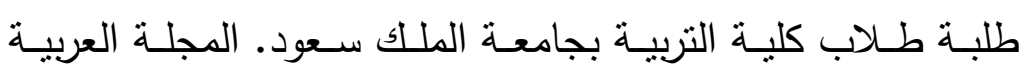

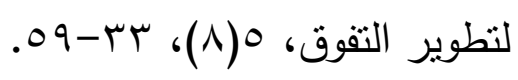

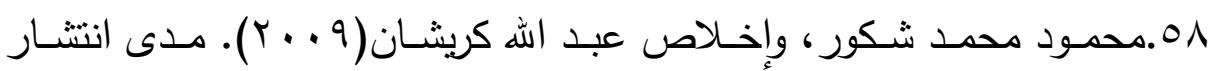

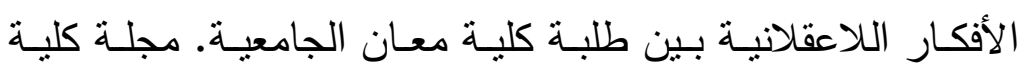

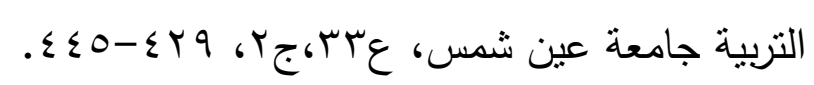

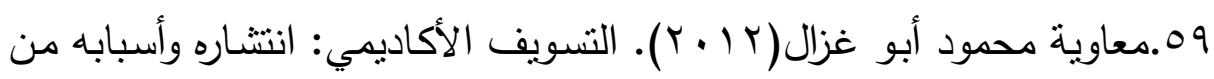

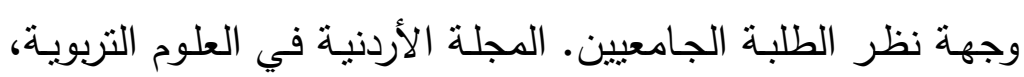

$$
.1 \leqslant 9-1 r \mid ،(r)^{\wedge}
$$

• T.معاوية محمود أبو غزال، وفراس أحمد الحموري، ومحمود حسن الحموري

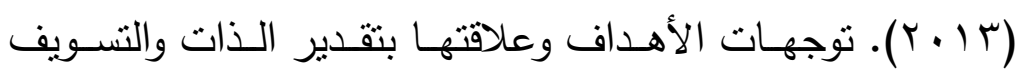
الأكاديمي لدى طلبة جامعـة اليرموك بالمملكة الأردنية الهاتـمية.

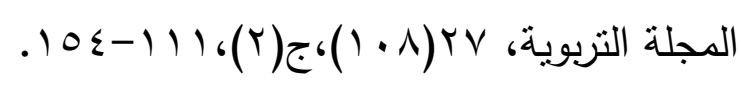

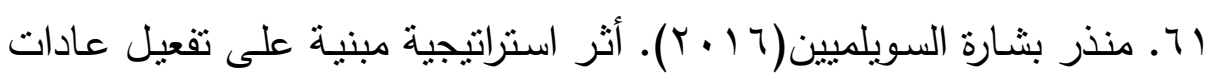
العقل في تعديل المفاهيم البديلة في العلوم وتتمية مهارات الأساسية

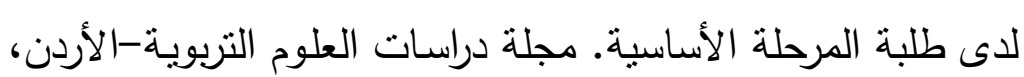

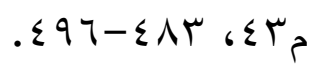

r آ. منى إبراهيم البنوي(0 . . r). التسرب الدراسي وعلاقته بالأفكار اللاعقلانية. رسالة ماجستير غير منشورة، جامعة مؤتة الأردن.

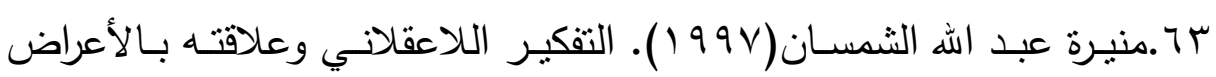
المرضية لدى طالبات الجامعة. رسالة ماجستير غير منشورة، كلية

$$
\text { التربية جامعة الملك سعود. }
$$

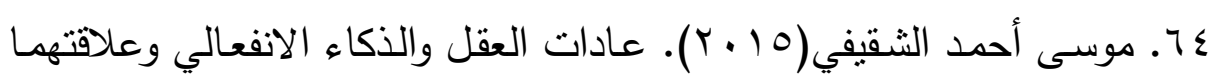
بالتحصيل الدراسي لدى طلاب الكلية الجامعية في القنفذة-المملكة 
العربيـة السـودية. المجلـة العربيـة لتطوير التفوق، ؟(1)، سب-

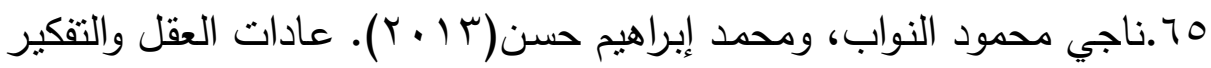
عالي الرتبـة وعلاقتهما بالفاعلية الذاتيـة لدى طلبـة كليـات التربيـة.

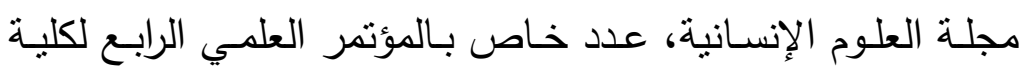

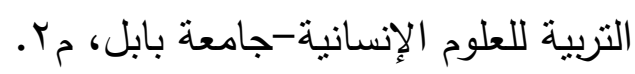

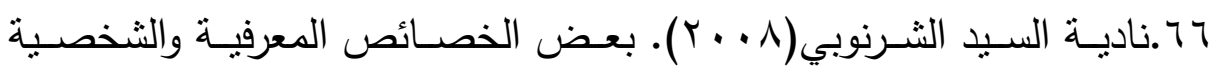

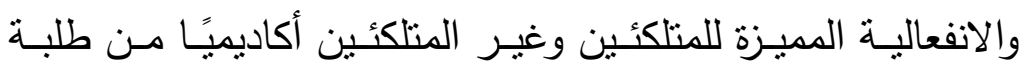

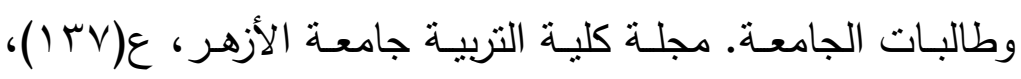

ج)

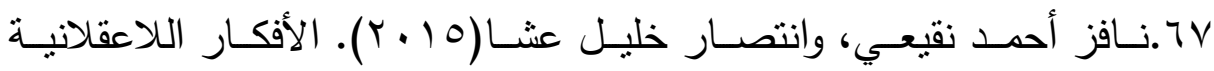
وعلاقتها بالحاجة إلى المعرفة لدى طلبة الجامعة. المجلة التربوية

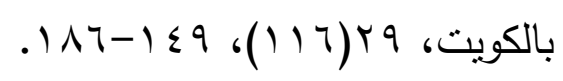

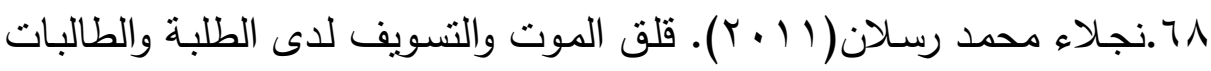

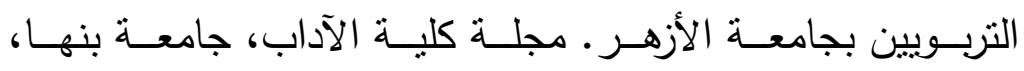

$$
\text { العدد(Y)، (Y)، }
$$

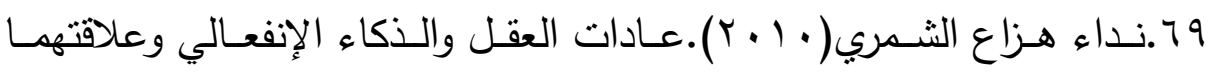
بالتحصيل الدراسـي لدى طلبة جامعـة الجوف في المملكة العربية السعودية. رسالة دكتوراه غير منشورة، جامعة اليرموك، الأردن.

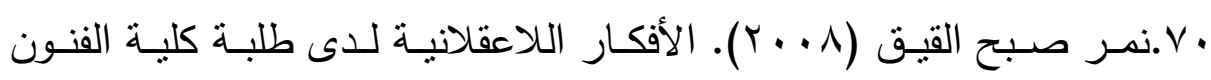

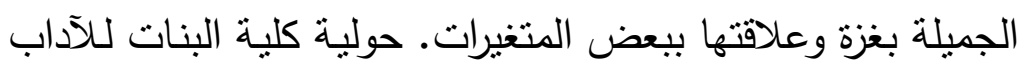

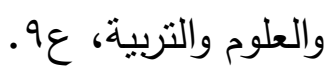

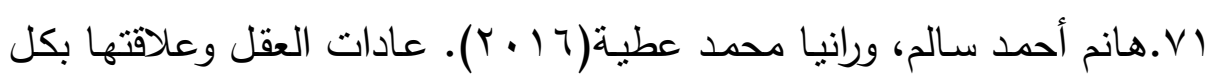
من اتخـاذ القرار وفاعليـة الذات لدى الطـلاب المتفوقين والعـاديين

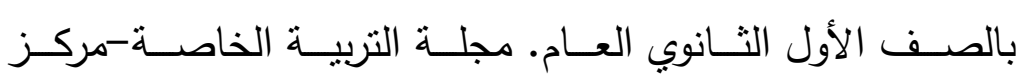


المعلومات التربوية والنفسية والبيئية بكلية التربية بالزقازيق، عء ) ، المبية

$$
.11 \mathrm{r}-0 \text {. }
$$

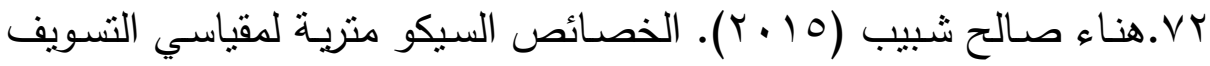

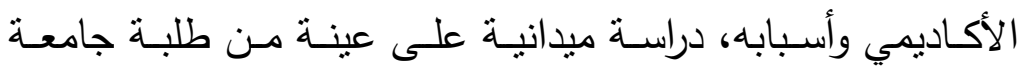
تشرين. رسالة ماجستير غير منشورة، جامعة تشرين بسوريا.

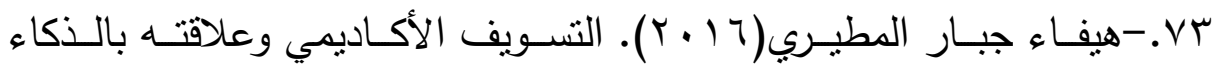

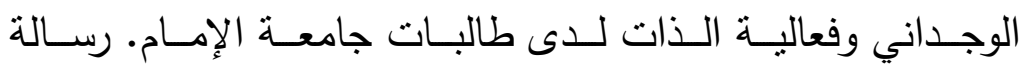
ماجستير -كلية التربية جامعة القصيم.

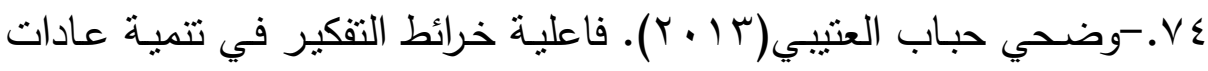

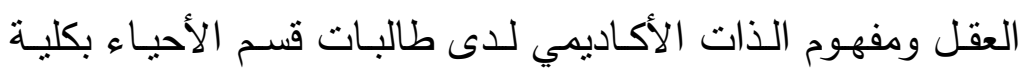

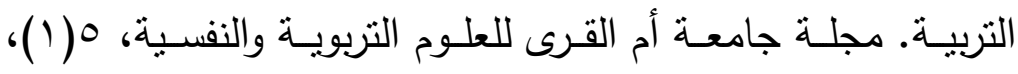

$$
. \text { YO. INV }
$$

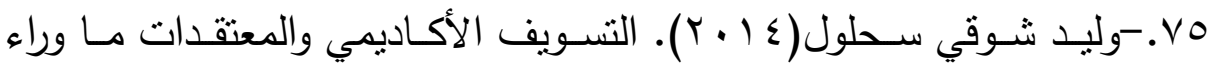
المعرفية حوله وعلاقتهما بالتحصيل الدراسي. مجلة دراسات تربوية

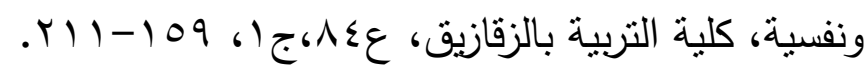

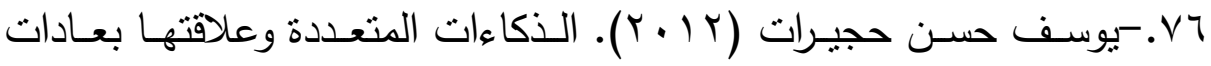
العقل لاى الطلبة الموهوبين. رسالة ماجستير غير منشورة، جامعة

$$
\text { عمان العربية. }
$$

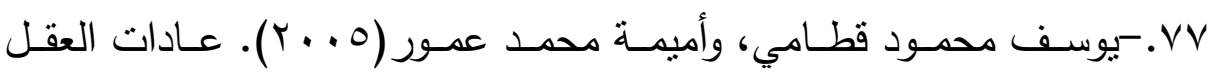
والتفكير (النظرية والنطبيق). عمان: دار الفكر .

\section{ثانياً: مرجع أجنية:}

78. Akinsola, M. \& Tella, A. \& Tella, A. (2007). Correlates of academic procrastination and mathematics achievement of University Undergraduate Students. Eurasia Journal of Mathematics\& Science\& Technology Education, 3(4). 


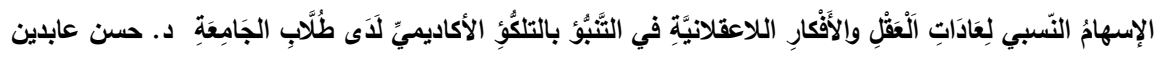

79. AL-Attiyah,A.(2011). Academic procrastination and its relation to motivation and self-efficacy: The case of Qatari Primary School Students. The international Journal of Learning, 17(8), 173-186.

80. ALquadah,M.\&ALSubhien,A.\&ALHeilat,M.(2014). The relationship between the academic procrastination and self-efficacy among sample of King Saud University students. Journal of Educational and Practice, 5(16).

81. Balkis,M.(2011).Academic efficacy as a mediator and moderator variable in the relationship between academic procrastination and academic achievement. Eurasian Journal of Educational Research, 45, 1-16.

82. Balkis, M.(2013). Academic procrastination, academic life satisfaction and academic achievement: The mediation role of rational beliefs about studying. Journal of cognitive and Behavioral Psychotherapies, 13(1).

83. Bergman,D.(2007). The effects of two Secondary Science teacher education Program Structure on Teachers habits of mind action. Ph.D., Lowa, America.

84. Beyer,B.(2003). Improving Students Thinking. The Clearing House, 71(5).

85. Boyacioglu,N.\&Kucuk,L.(2011). Irrational Beliefs and Test Anxiety in Turkish School Adolescents. Journal of School Nursing, 27(6).

86. Bridgees, K. \& Riog, M. (1997). Academic procrastination and irrational thinking: Are examination with context controlled. Personality and Individual Differences, 22(6).

87. Brownlow, S. \& Reasinger, R. (2000). Putting off until tomorrow what is better done today: Academic procrastination as a function of motivation toward 


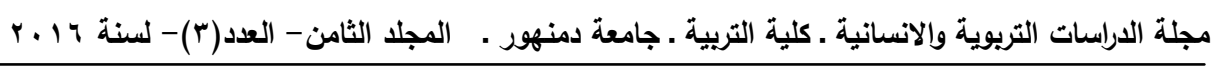

college work. Journal of Social Behavior and Personality, 15.

88. Cao,L.(2012). Differences in procrastination and motivation between undergraduate and graduate students. Journal of The scholarship of Teaching and Learning, 12(2).

89. Choi,J.\&Moran,S.(2009). Why not Procrastination? Development and validation of active procrastination scale. The Journal of Social Psychology.

90. Chu, A., \& Choi, J. (2005). Rethinking procrastination: Positive effects of active procrastination behavior on attitudes and performance. Journal of Social Psychology .145(4), 245-264

91.-Costa, A. \& Kallik, B.(2000).Habits of mind. Alexandria VA (U.S.A.): Association for Supervision and Curriculum.

92.-Costa,A.(2001). Developing minds: resource book for Teaching Thinking. Alexandria VA(U.S.A.): Association for Supervision and Curriculum.

93.-Costa, A. \& Kallik, B. (2008). Learning and leading with habits of mind: 16 essential characteristics for success, association for supervision and curriculum development, Alexandria, Virginia: U.S.A.

94. Demeter, D. \& Pavis,S.(2013). Procrastination as a tool: Exploring unconventional components of academic success. Education, 4(2A2).

95. Dewitt,S.\&Schouwenburg,H.(2002). Procrastination, Temptation and Incentives: The Struggle between the present and the future in procrastinators and punctual. European Journal Personality, 16(6).

96. Dryden,W.\&Sakia,S.(2010). Effectiveness of Rationalemotive Counseling on reducing academic 


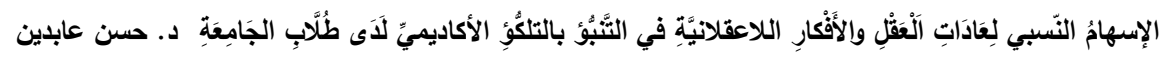

procrastination. Journal of Rational-

Emotive\&Cognitive -Behavior Therapy, 14(9).

97. Ellis,A.(1990). Rational and Irrational in counselling British Psychological Association. Journal of Rational Emotive and Cognitive Behaior Therapy,8(4), 221-233.

98. Ellis,A.(1994). Reason and emotion in Psychotherapy. Secaucus, NJ: Brich Lane.

99. Ellis,A.\&Knaus,W.(2002). Overcoming Procrastination. New York: New American Library.

100. Ellis,A.\&David,D.\&Lynn,S.(2010). Rational and Irrational Beliefs. New York: University Press Oxford.

101. Eva,G.(2002).Toward dynamic assessment of reading: Applying metacognitive Awareness guide to reading Assessment tests. Journal of Research in Reating, 25(3), 283-398.

102. Flett,A.\&Haghbin,M.\&Pychyl,T.(2016). Procrastination and Depression from a cognitive perspective: An Exploration of the Associations among procrastinator Automatic Thoughts, Rumination, and Mindfulness. Journal Rat-Cognitive- Behavior Therapy, 34,169-186.

103. Grant,C.(2009). The relationship between procrastination and Intrapersonal Intelligence in College Students. Unpublished Doctoral Dissertation, University of North Dakota, U.S.A.

104. Habelrih,E.\&Hicks,R.(2015). Psychological well-Being and its relationships with active and passive Procrastination. International Journal of Psychological Studies, 7(3), 25-35.

105. Holmes, R. A (2002), .The Effect of Task Structure and Task Order on Subjective Distress and Dilatory Behavior in Academic Procrastinators. 


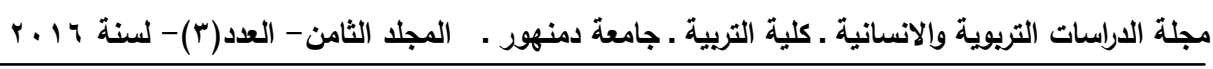

Unpublished doctoral dissertation, Hofstra University.

106. Jiao,Q.\&Daros-

voseles,D.\&Collins,K.\&Onwuegbuzie,A.(2011).

Academic procrastination and the performance of graduate-level Cooperative groups in research methods course. Journal of the Scholarship of Teaching and Learning, 11(1), 119-138.

107.Kandemir,M.(2014). The Predictors of Academic Procrastination, Responsibility, Attributional Styles Regarding Success/Failure, and Beliefs in Academic self-efficacy. Education and Science, 39(171), 99-114.

108. Khan,M.\&Arif,H.\&Noor,S.\&Muneer,S.(2014).

Academic Procrastination among male and female University and College Students. FWU Journal of Social Sciences, 8(2).

109. Klassen,R.\&Kuzucu,E.(2009). Academic procrastination and motivation of adolescents in Turkey. An International Journal of Experimental Educational Psychology, 29(1).

110. Lavoie,C.\&Koestner,R.(1997).Trait and Situational facts in Procrastination. An Interactional Model. Journal of Social Behavior\& Personality, 12(4), 889-903.

111. Lay,c.(1986). At last, my research article on procrastination. Journal of Research in Personality, 20,474-495.

112. Marzano,R.(1992). A different Kind of Classroom Teaching with dimensions of Learning. Alexandria Victoria: Association for supervision and Curriculum Development. 


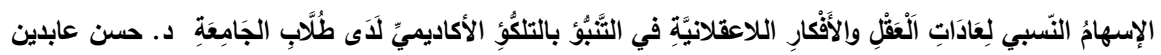

113. Marzano,R.(2000). Transforming classroom grading. Alexandria Victoria: Association for supervision and Curriculum Development.

114. Mayer,C.(2000). Academic Procrastination and selfhandicapping: gender differences in response to noncontingent feedback. Journal of Social Behavior and Personality, 15, 87-102.

115. Mccloskey, j.(2011). Finally, My Thesis on Academic procrastination. Master Thesis, Texas University.

116.

Michinov,N.\&Brunot,S.\&Bohec,O.\&Juhel,J.\&Del aval,M.(2011). Procrastination, Participation, and Performance in online Learning environments. Computers \& Education, 56.

117. Odaci,H.(2011). Academic self-efficacy and procrastination as predicators of problematic Internet use in University Students. Computers\& Education, 57, 1109-1113.

118. Ozer,B.\&Ferrari,J.(2011). Gender Orientation and Academic Procrastination: exploring Turkish high school students. Individual Differences Research, 9(1), 33-40.

119. Ozer,E.\&Akgun,O.(2015). The Effects of irrational beliefs on Academic motivation and academic self-efficacy of Candidate teachers of computer and instructional technologies educational department. Procedia - Social and Behavioral Sciences, 197, 1287-1292.

120. Popoola,B.(2005).Astudy of the relationship between procrastinatory behavior and academic performance of undergraduate Students in a Nigerian university. Contribution from Educational Psychology, 16K 161-165. 


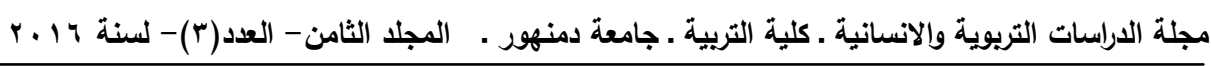

121. Rabin,L.\&Fogel,J.\&Nutter-Upham,K.(2011).Academic procrastination in college studends: The role of self-reported executive function. Journal of Clinical and Experimental Neuropsychology, 33(3),344-357.

122. Rakes,G.\&Dunn,K.(2010). The impact of online graduate students' motivation and self-regulation on academic procrastination. Journal of Interactive Online Learning, 9 (1), 78-93.

123. Regan ,B. (1999). Habits of mind: A moment in the Lived experience of teaching, Teaching Education , 16 (1).

124. Sapp, M. (1996). Irrational Beliefs that can lead to academic failure for African American Middle School students who are academically At-risk. Journal of Rational-Emotive\& Cognitive Behavior Therapy, 14(2).

125. Seo, E. (2013).A Comparison of active and passive procrastination in relation to academic motivation. Social Behavior and Personality, 41(5).

126. Sherry, S. \& Hewitt, P. \& Flell, G. \& Harvey, M. (2003). Perfectionism dimensions, Perfectionistic attitudes, dependent attitudes, and depression in psychiatric patients and University students. Journal of Counselling Psychology, 50.

127.Simpson,K.\&Timothy,A.(2009). In Search of arousal Procrastinator, Investigating the relation between procrastination, motivations. Personality and Individual Differences, 47(8), 906-911.

128.Sirin, E. (2011). Academic procrastination among undergraduates attending school of physical education and sports: Role of general procrastination, academic motivation and 


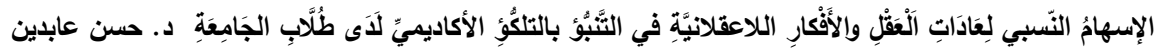

academic self-efficacy. Educational Research and Review. 6(5).

129.Steel,P.(2010). Arousal, Avoidant and Decisional procrastinators: Do Theyexist?. Personality and Individual Differeces,48, 926-934, http: //dx.doi.org/10.1016/j.paid.2010.02.025

130.Toker,B.\&Avci,R.(2015). Effect of Cognitive-Behavioral Theory based skill Training on Academic Procrastination behaviors of University students. Educational Science: Theory \&Practice, 15(5), 1157-1168.

131.Tuckman, B. (2005). Relations of academic procrastination, rationalizations, and performance in a web course with deadlines. Psychological Reports, 96, 1015-1021.

132.Wiersema, J. \& Licklider, B. (2009). Intentional Mental Processing: Student Thinking as a Habit of Mind. Journal of Ethnographic\& Qualitative Research, 3(1), 117-127.

133.Wolters, C. (2003). Understanding procrastination from a self-regulated learning perspective. Journal of Educational Psychology, 95, 179-187.

134.Wong,B.(2012).Metacognitive awareness, Procrastination and Academic Performance of University students in Hong Kong. Doctoral Thesis, University Leicester.

135.Yaakub,N.(2000). Procrastination among students in institutes of higher Learning: Challenges for Economy .Available at://www.mahdzan. com/ papers /procrastinate/.

136.Yazici, H. \& Bulut, R. (2015). Investigation into The academic procrastination of teacher candidates' social studies with regard to their personality 
مجلة الاراسات التربوية والانسانية ـ كلية التربية ـ جامعة دمنهور . المجلد الثامن - العدد(ץ)- لسنة ז 1 ـ ب

traits. Procedia-Social and Behavioral Sciences, 174.

137.Yerdelen,s.\&McCaffrey,A.\&Klassen,R.(2016).Longitudi nal Examination of Procrastination and Anxiety, and their relation to self-Efficacy for selfregulated Learning: Latent Growth Curve Modeling. Educational Sciences, Theory\& Practice, 16(1), 5-22.

138. Yockey,R.(2016). Validation of the Form of Academic Procrastination Scale. Psychological Reports, 118(1). 


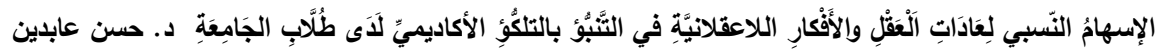

